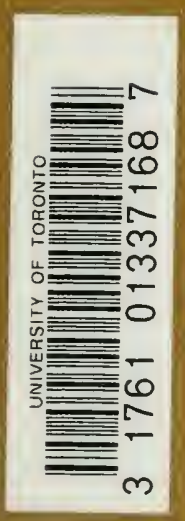





ENGLISH FARMING 

THE

\section{PIONEERS AND PROGRESS}

OF

\section{ENGLISH FARMING}

ROWLAND E. PROTHERO

BARRISTER -AT-LAW, AND FELLOW OF ALL SOULS COLLEGE, OXFORD

\section{LONDON}

L ONGMAN, GREEN, A N D CO. AND NEW YORK : 15 EAST $16^{\text {th }}$ STREET 1888 


$$
\begin{aligned}
& 4=2 \\
& 4=7 \\
& =558
\end{aligned}
$$




\section{PREFACE}

Portions of the following pages have already appeared within the last three years, in the Edinburgh and Quarterly Reviews, and my thanks are due to the Publishers for their permission to utilise the material which has been previously published in these periodicals. The recent appearance of two of the Articles on which I have relied will, I hope, excuse the seeming conceit of my references to 'Rural France' (Edinburgh Review, October 1887) and 'The Tithe Question' (Edinburgh Review, January 1888).

The first part of the volume contains a brief sketch of Agricultural Progress, derived from sources so scattered or so obscure that its presentation in a connected form may prove of interest. In the second part, I have endeavoured to apply the results of history to the present conditions of English farming. I am fully conscious that the task is difficult, and that it is inadequately performed; but the fact that in any Session of Parliament, which is mainly devoted to British interests, Agriculture necessarily holds a prominent place, explains, though it may not justify, the attempt.

R. E. Prothero. 



\section{CONTENTS}

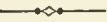

\section{CHAPTER I. \\ 'SELF-SUFFICING FARMIING.'}

Light Soils the Sites of earliest Settlements-Nomadic Stage represented in 'Wild-field-grass Husbandry' of S.W.-Farming of Village Communities: 'Garstons,' Arable Fields, Meadows, Hams, Pastures-'Traces of System at Present Day-Manors imposed on Village Communities at Norman Conquest-Divisions of Land and Classes on Mediæval Manors: Tillage, Crops, Harvest, Implements, etc. - Progress of Agricultural Classes illustrated from Castle Combe . . . . .

\section{CHAPTER II.}

\section{FARMING FOR PROFIT.}

Social and Agricultural Crisis at Close of Tudor Period-Selfsufficing Farming supplanted by Farming for Profit, Common by Individual Ownership, Feudal Retainers by Rent-paying Tenants; Pasture displaces Tillage, Sheep the Plough; Commons and Open Fields enclosed-Ruin of Small Commoners and Labourers for Hire-Their Misery under the TudorsIllustrations of Methods by which Commons were enclosed .

\section{CHAPTER III.}

\section{THE SEVENTEENTH CENTURY.}

Progress in Farming-Commencement of Agricnltural Literature: Fitzherbert and Tusser-Arrest of Progress during the Civil War-Accumulation of New Sources of Agricultural Wealth: Turnips, Artificial Grasses, Drainage, Emancipation of Land from Feudal Tenures 


\section{CHAPTER IV.}

\section{TURNIP TOWNSHEND AND THE NORFOLK SYSTEM.}

1700-60 the Golden Age of Agricultural Classes, followed by Period of Corresponding Adversity-Reaction during First Half of the Century from Pasture to Tillage, from Sheep to Arable Farming, from Encouragement of Wool to Bounties on Corn-Suffolk and Essex the Best Types of 17th Century Farming-Townshend's System revolutionises the Agriculture of Norfolk, and, through Norfolk, of England-Cultivation of Turnips and Clover

\section{CHAP'TER V.}

BAKEWELL AND TIIE GRAZIER'S ART.

Improvements effected in Breed of Sheep and Cattle by Bakewell -His extraordinary Success with Sheep, and comparative Failure with Cattle-His Imitators: Ellman and Jonas Webb, Collings, Tomkins, and Quartley . . . . .

\section{CHAPTER VI.}

\section{ARTHUR YOUNG AND THE DIFFUSION OF KNOWLEDGE.}

Vast Tracts of Waste and Unenclosed Land; Leases practically unknown; Ignorance and Prejudices of Farmers; Difficulties of Communication rendered almost insuperable by Condition of Roads; Traditional Practices regarded as Agricultural Heirlooms-Early Life of Arthur Young; his Exertions to remove Obstacles to Progress of Agriculture . . . .

\section{CHAPTER VII.}

ENCLOSURES OF OPEN FIELDS AND COMMONS FROM 1770 TO 1820 .

Second Agricultural Crisis-Enclosure of Wastes or Open Fields, and Consolidation of Holdings an Economic Necessity owing to Growth of Manufacturing Population-Impossibility of introducing new Agricultural Methods among Open-field Farmers-Reports of Board of Agriculture, 1793-Enclosure of Commons indispensable for increased Supply of Food, but often injurious to Interests of Poor . . . . . . 


\section{CHAPTER VIII.}

LARGE FARMS AND LARGE CAPITALISTS-MR. COKE, OF HOLKHAM.

Manufactures create New Markets for Food, and encourage Investments of Capital in Land-Landlords take the Lead in Agricultural Improvements--Wheat Growing and Stock Feeding in Norfolk-Mr. Coke, of Holkham, as the Model Landlord-Holkham Sheepshearings-Effect of War Prices on Ownership of Land; Disappearance of Small Freeholders and Consolidation of Large Estates . . . . . .

\section{CHAPTER IX.}

SCIENCE WITH PRACTICE, 1812-45.

Agricultural Progress during present Century-1812-42, a Period of wide-spread Ruin and Protection--Unprecedented Dearness of Corn maintained by heary Import Duties-Distress of Wage-earning I'opulation, Ruin of Landlords, Bankruptcy of Farmers at the Close of War-Paper-money and Resumption of Cash Payments aggravate Distress-Machine-breaking, Incendiarism, and Agrarian Outrage-Clay Farms suffer most heavily-Necessity of Drainage; Science provides necessary Means: Blith, Young, Elkington, Smith of Deanston, Josiah Parkes, Land Improvement Loans-Stimulus given to Drainage by Artificial Manures-Manures ignored by Early Agricultural Writers; 'Nothing like Muck' means 'Nothing but Muck;' Discoveries of Sprengel, Liebig, Lawes, Henslow, Odams-Agriculture revived by general Industrial Progress, Legislative Aid, and improved Practices and Implements of Farming-Good Effect upon Farming of inflated War Prices, illustrated from Northumberland and the Life of John Grey of Dilston

\section{CHAPTER X.}

\section{SCIENCE WITH PRACTICE, 1845-73.}

Enclosure Act of 1845 and Free Trade inargurate New Era of Intensive and High Farming-Caird's Pamphlet on High Farming-Period of Great Agricultural Prosperity-Its Causes-Characteristic of Time rather Diffusion than Inven- 
tion of Improved Farming Practices-Services of Chemistry, Geology, Mechanics, and Steam-Effect of Union of 'Science with Practice' upon Farmers, and other Classes connected with Agriculture-Another Result of Union seen in Demand for Compensation for Unexbausted Improvements-Statistical Records of Agriculture; Sir James Caird and Sir John Lawes

\section{CHAPTER XI.}

\section{AGRICULTURAL DEPRESSION, 1S73-S7.}

New Element of Foreign Competition-Revival of old Complaints-Gold a Factor in previous Eras of Adversity or Prosperity, and a concurrent Cause in present Crisis with Foreign Competition, Reckless Trading and Over-production -Exceptional Demand for, and Decreasing Supply of Gold -Depreciation of Silver-Full Pressure of Foreign Competition only felt after 1873-Low Prices the Problem of Modern Farming-Effect of Crisis on Landlords, Farmers, and Labourers-No True Distinction on score of Property possible between Money invested in Land and Money invested in Funds-Danger of wild Theories of Land Nationalisation .

\section{CHAPTER XIT.}

\section{PEASANT PROPRIETORS.}

Peasant Proprietors the chief theoretical Remedy-Prevalence of Distress among the Class in France and Germany-Impossibility that Remedy can apply universally in England-Proof of this from Example of France; special Conditions for Success of Peasant Proprietary in Soil, Climate, or Domestic Industries-Objections against French System: excessive Subdivision, Mortgage Debts, and scattered Parcels of LandHardships of the Life of French Peasantry-Social and political Adrantages of System-Peasant Proprietary in France not the Growth of Legislation-Futility of Attempts to create the Class in England 


\section{CHAPTER XIIT.}

\section{LANDLORDS AND NATURAL GROWTI.}

Explanation of different Lines of Agricultural Development in France, Belginm, the German Empire, Austria, Russia, Denmark-Paucity of Number of Landowners in England-Agricultural Progress due in England to Private Capital and Enterprise-In France Government supplies Place of LandlordsState-directed Agriculture in France: Education, Horse-races, Shows, Veterinary Assistance, Drainage, Roads, Public Works .

\section{CHAPTER XIV.}

\section{DISTRIBUTION OF LAND.}

Number of Landlords; of Farmers and Size of their Holdings ; of Agricultural Labourers-Distress not due to System of Land Tenure or Cultivation-Losses of Agriculturists counterbalanced by Gain of Middle and Wage-earning Classes-Measures of Agricultural Relief limited by small Numbers of Persons directly interested in Agriculture

\section{CHAPTER XV.}

\section{PROTECTION AND TITHE RENT-CIIARGE.}

Protection in England at Commencement of Century, and in France and Germany at present Time-Improbability of Landlords and Farmers obtaining Protection-Unlikely that Tithe Rent-charge will be reduced-Object and Effect of Tithe Commutation Act of 1836-Proportion borne by Tithe to Rent less in 1888 than in 1836-Consequently no Ground for Demand for Reduction of Charge-Change in Incidence of Charge necessary - No final Solution of Difficulty except Redemption -Interests of Church and State best consulted by State Collection of the Charge, and gradual voluntary Redemption in better Times and at higher Prices . . . . . 


\section{CHAPTER XVI.}

LEGISLATIVE AID; LAND LAWS, LAND TRANSFER, EDUCATION, RAILIVAY RATES.

Former Feeling of Insecurity among Landlords fostered by doubtful Attitude of Legislature - Revived Confidence not impaired by Removal of Artificial Hindrances to Natural Growth of Small Owners-Reform of Land Laws and Establishment of Land Registration-Difficulties of cheap and easy System of Land Transfer-Lord Halsbury's Bill, 1887-Anstralian and Prussian Registries-Advantages of Land RegistriesAgricultural Education in Great Britain and Ireland compared with that of France, and the Austriau and German Empires-Tecbnical Teaching in Agricultural Matters especially needed in Rural Schools-Use of Ninistry of Agriculture-Commencement of State Aid in England-Illustration of Working of System in France-Unfairness of present System of Differential Railway Rates, especially in case of Perishable Produce--Need for a Board of Control . . . . . . . .

\section{CHAPTER XVII.}

FISCAL RELIEF-LOCAL TAXATION.

During Protection Period Agricultural Land was heavily taxed because Consumers were beavily taxed for its SupportCessante ratione cessat et ipsa lex - The Land Tax - The four old Rates before and after the Repeal of the Corn Laws-Increased Burden of Local Taxation in spite of Free Trade Prices-Comparison of Rates in 1841 and 1885-Enormous Growth of Local Debt-Need of Reform of Local Government-Suggestions for Relief of Agricultural Land from Local Taxation

\section{CHAPTER XVIII.}

SELF-HELP NOT PROTECTION.

Self-Help the true Remedy-Perishable Produce the main Source of Farming Profits-Signs of New Departure in these Directions-Co-operation necessary between Laudlords and Tenants - Farmers not Free A rents in Cuntracts for letting and hiring 
Land-Necessity of securing them agaiust Rise of Rent based upon their own Outlay of Capital-Defects of Agricultural Holdings Acts of 1875 and 1883-Proposed Scheme to secure them Compensation-Freedom in Contract from Antiquated Restrictions-Sliding Scale in Rents-Reaction apparently imminent from Corn-growing to Meat and Dairy FarmingAdvantages of diversified Husbandry . . . .

\section{CHAPTER XIX.}

\section{AGRICULTURAL LABOURERS.}

Agricultural Labourers as yet the smallest sufferers from Agricultural Depression-Improvements in their Moral and Material Circumstances-Three Wants of their present ConditionPeasant Tenancies; Means of providing necessary Capital_Good Prospects for Agricultural Labourers who become Small Farmers or secure regular Employment-Allotments-Probable Dismissal of large Numbers of Labourers - No possible Restoration of Balance between Demand and Supply of Labour except Emigration

\section{CHAPTER XX.}

\section{APPENDICES}

I. Prices of Wheat . . . . . . . . 243

II. Social Corn Laws . . . . . . . . . 246

III. Agricultural Writers of the 16th, 17th, and first half of 18 th Centuries . . . . . . . . . . . 248

IV. The Corn Laws $\quad$. $\quad$. $\quad$. . . . 252

V. Enclosures . . . . . . . . . . 257

VI. Questions of the Board of Agriculture, 1816 . . . . 258

VII. Estimate of the Agricultural Population in 1688, and Census Returns of $1851,1861,1871,1881 \quad$. . . . 259 
PAGE

VIII. Production of Gold and Silver, 1851-86, \&c. . . . . 261 IX. Value of Imports of Food . . . . . . . . 263

X. Statistics of Agriculture • . . . . . . . . 264-5

XI. The Land of England and its Products, 1688, 1771, 1808, $1827,1867,1877,1887$ • $\quad . \quad . \quad . \quad 268$

XII. Prices of Wheat and Import Duties, if any, in France, Belgium, Prussia, and England . . . . . . 274

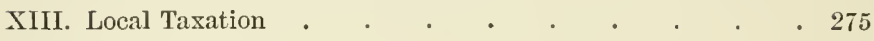

XIV. Allotments . . . . . . . . . . 277

XV. Wages of Agricultural Labourers . • . . . . 279

XVI. Prices of Provisions . . . . . . . . . 281

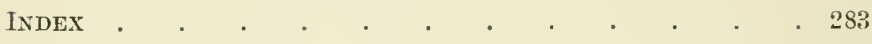




\section{PIONEERS AND PROGRESS}

OF

\section{ENGLISH FARMING.}

\section{CHAPTER I. \\ SELF-SLFFICIYG FARMING.}

THE practice of English Agriculture was in its infancy solely determined by the growth of population. No rotation of crops was necessary till advancing numbers limited the extent of the moccupied land. While people were few and land was abundant, grain crops were only raised on light soils. Dry uplands, where the least labour told the most, were first cultivated; rich valleys, damp and filled with forest growth, remained uninhabited. Sandy soils or chalky highlands are the sites of the oldest villages. Patches of the slopes of downs were cleared of self-sown beech, and sheltered dips tilled for corn ; the high ground behind was grazed by the flocks and herds; the beech woods supplied mast for the swine. On Salisbury Plain, a century ago, there was no sign of human life except the proverbial 'thief or twain;' no contemporary mark of' the hand of man but the gallows and their appendages. Yet here are to be found traces of numerous villag'es. The 
sides of the Wiltshire and Sussex downs are scored with 'lynches,' terraces running horizontally, one above the other, along the slopes. Local traclition attributes their formation to spade husbandry. Marshall, in 1797, suggested, but only to reject, the operation of the plough; recently Mr. Seebohm has revived the same theory. Whichever view of their origin is correct, they indelibly indicate the sites of the earliest settlements, and the nature of the soil first selected for tillage.

'Wild field-grass' husbandry is a more primitive form of agriculture than that practised by village communities. Of both systems co-ownership and co-tillage are characteristic. The essential difference lay in this. In the common fields of the village, pasturage and tillage are permanently separated; grass-land alwars remains meadow or pasture; it is never broken up for tillage. Under the more primitive form fresh tracts of grass were successively taken in, ploughed, and tilled for corn. As the soil became exhausted they reverted to pasture. Such a practice may belong to some portions of the Celtic race, or to the nomadic stage of civilisation, the period when 'arva per aunos mutant et superest ager.' In 1804 Marshall traced the 'wild field-grass' system in the sonth-western counties. In some districts, lords of the manor enjoyed rights of letting portions of the grass commons to be ploughed up, cultivated for corn, and after two years thrown back into pasture. And orer the whole country from the Tamar to the eastern border of Dorsetshire he found open commons, such as the wide expanse of Yarcombe and the hills above Bridport, which from time immemorial had never known the plough, distinctly marked with the ridge and furrow. Other usages of the rural population, which a century ago were more peculiar to the south-west of England, suggest that in this 
district village communities never prevailed. The cultivated land is divided into little patches by the high Devonshire hedge; common parish fields can hardly be traced; fewer of the inhabitants are collected into villages, more are scattered in single houses. The small enclosures suggest that Deronshire was never peopled by Teutonic invaders; like Brittany, it is a comntry of hedges.

On this system the permanent separation of arable land from pasture hardly constitutes an advance in agricultural practice. It was probably introduced into this country by a people accustomed, like the Anglo-Saxons, to a drier and less variable climate. Yet this alien system for centuries governed the cultivation of two-thirds of England. Tufts of trees, conspicuous in the hedgeless expanse of land by which they were surromded, marked the sites of villages, as they still do in the high table-land of the Pays de Caux. Within the 'tùn,' or enclosmre, were the tofts and crofts of substantial peasants and the cottages and curtilages of the cottagers, 'fencèd al abonte with stikkes.' These were the only property held by the members of the township in several ownership. They were also originally the only permanent enclosures. But as agriculture advanced, yards ('gerstuns,' or garstons) for rearing stock, or for the oxen which could not 'endure his warke to labour' all daye, and then to be put to the commons or before the herdsman,' were enclosed in the immediate proximity of the village. In these enclosures, or ' happy garstons,' as they were called at Aston Boges, were held the village merry-makings, the rush-bearing's, the May-games, the summerings at St. John Baptist's Eve, the pnblic breakfasts, and the distribntion of bread and ale in Rogation week.

Beyond the village lay the common arable fields, including the driest and soundest land. These fields were 
two and three, or rarely four in number. If the former, one field lay fallow, the other under tillage for corn, or beans, or peas. The dual system was, when Fleta wrote, generally superseded by the three-field or trinity arrangement; yet it prevailed near Gloucester in the present century, and existed at Stogoursey in Somersetshire in 1879. From the reign of Henry III. to that of George III. the trinity fields received the unvarying triennial succession of wheat or rye, spring crops such as barley, oats, beans, or peas, and fallow. During this period a more scientific rotation was in some districts adopted. Thus at Aston Boges, in Oxfordshire, a fourth course was interposed. But, speaking generally, common field husbandry rather retro graded than advanced. For the strict supervision of the bailiff and the reeve, or the minute observance of common rules, was exchanged an anarchy which made the land, like that of 'Tully Veolan, resemble in the 'nnprofitable variety of its surface a tailor's book of patterus.'

Each of the three arable fields was subdivided into shots, furlongs, or flats, separated from one another by mploughed, bush-grown turf balks. These flats were in turn cnt up into parallel strips of about an acre apiece, coinciding with the arrangement of a ploughed field in ridges and furrows. Theoretically each flat was a square of forty poles, containing ten acres; in practice every variety of shape and admeasurement was found. But, though the pole from which the acre was raised varied from the thirteen and a half feet of Hampshire to the twenty-four feet of Cheshire, two sides of the flats always ran parallel. Thus each of the three arable fields resembled several sheets of paper, ruled with margins and lines. The separate sheets are the flats; the margins are the headlands running down the flats at right angles to, 
and across the ends of, the parallel acre strips which are represented by the lines. The strips appear under different names. In Scotland they were called 'rigs,' in the north of England generally 'oxgangs,' in Westmoreland ' dales,' and their possessors 'dalesmen,' in Cambridgeshire 'balks,' in Somersetshire 'landshires' or ' raps.' They generally contained an acre, but half-acres and even single poles or rods, called 'butts,' are found. Stray odd corners which did not fit in with the parallel arrangement of the shots were called 'crustæ,' " that is, pieces broken off, pightels, ${ }^{2}$ ' gores, ${ }^{3}$ fothers, ${ }^{4}$ and pykes, becanse, as Fitzherbert explains, they were 'often brode in the one ende and a sharpe pyke in the other ende.' These strips, thus scattered over the arable fields, were fenced off for the separate use of individuals from seedtime to harvest. On Lammas Day separate use terminated and common rights recommenced; hence the strips were often called Lammas lands. After harvest the hayward removed the fences, and the cattle of the community wandered over the fields before the common herdsman. S'ometimes each commoner herded his own flock. Richard Hooker, while he held the country living of Drayton Beauchamp in Buckinghamshire, was found by two of his former pupils, 'like humble and innocent Abel, tending' his small allotment of sheep in a common field.' That no occupier might find all his land fallow in the same year. every one had strips in each of the three arable fields. If

1 Registry of Worcester Priory (Camden Society), p. 18A.

2 A pightel of land. Cf. Cullum, History of Hansted, p. 77.

${ }^{3}$ As in Kensington Gore.

${ }^{4}$ Cf. Chaucer (Prologue, 530),-

'A ploughman, his brothur,

That hadde i-lad of dong ful many a fothur,'

where the word is generally taken to mean a load. 
the holding was a virgate of thirty acres, there wonld be ten acres in each field. To divide equally the good and bad, well and ill situated soil, the bundle of strips allotted in each field did not lie together, but was scattered.

In the lowest part of the land-if possible along a stream-lay the 'ings,' or meadows, annually cut up into lots or doles, and put up for hay. These doles were fenced off for the separate nse of individuals from Candlemas to Midsummer Day : from July to Febrnary they were open, common pasturage. Each lot was distinguished by a mark, such as the cross, crane's foot, or peel. Corresponding marks were thrown into a hat or bag and drawn by a boy. This balloting continued up to the present century in Oxfordshire and Somersetshire. No winter keep for stock was provided; the common field farmer could only fatten cattle at the wane of the summer. Then they had the aftermath of the meadows, the stubble or haulm of the arable fields. After Michaelmas they steadily declined, and only survived the winter in a state of semi-starration. Hence worn-ont oxen or aged cows were slanghtered in the autumn and salted for winter consumption. 'For Easter at Martylmas hang up a beef,' is the advice of Tusser.

On the outskirts of the arable fields lay one or more 'hams' or stinted pastures, supplying superior feed. Brandersham, Smithsham, and Wontnersham suggest that special allotments were made to those who practised crafts of general ntility.

The poorest and most distant land of the township was left in its native wildness. It afforded timber for fuel or fencing, mast and acorns for swine, rough pasture for the ordinary live stock.

The common field system, thus briefly sketched, with 
its arable, meadow, and pasture land, prevailed at some time or other throughout England except in the west, and underlies the disturbances in Skye. The following description of the crofters' holdings in 1750 might have been written, with but few alterations, of half the villagers in England in the eighteenth century :' - A certain number of tacksmen formed a copartnery and held a tract of land, or township, for which they paid tribute to the chief, and each member was jointly and severally responsible. The grazing was in common. All the arable land was divided into ridges, assigned annually by lot among the partners. Each might have a dozen or more of these small ridges, and no two contiguous except by accident; the object being to give each partner a portion of the better and inferior land. The copartner appears to have had cotters under him, for whose work he paid.' In 1879, at Stogoursey, near Bridgwater, a village community were still cultivating 600 acres of land on similar principles. The prevalence of the system may still be faintly traced in England. Turf balks and lynches record the time when 'every rood of ground maintained its man." Irregular and regular fences, straight and crooked roads, respectively suggest the wholesale or piecemeal enclosure of common fields. The age of the hedgerow timber sometimes tells the date of the change. The space devoted to hedges by agricultural writers of the eighteenth century denotes the abolition of open fields, and the minuteness of their instructions proves that the art of making hedges was still in its infancy. The scattered lands of ordinary farms, compared with the compact 'court,' ' hall,' or 'manor' farm, recalls the fact that the lord's demesne was once the only permanent enclosure. The crowding

1 Letter to the Times, April 3, 1883. 
together of the rural population in villages betrays the agrarian partnership, as detached farmsteads and isolated labourer's' dwellings indicate the system by which it has been supplánted.

The relation of manors to village communities lies beyond the present inquiry. Two theories explain the origin of manorial rights and rights of common. The legal theory, in its crudest form, is that the lord of the manor is absolute owner of the soil of his manor, and that all rights acquired over it by freebolders and copylolders are acquired against him, and originate in his grant or sufferance. The historical theory is that self-governing, independent communities of freemen originally owned the land in common, and were gradually reduced to dependence by one of their members, who became the lord of the soil. If the second theory is correct, the legal position of the lord of the manor represents a series of encroachments which transformed the Mark of freemen into the Manor of villeins, and transmuted the customary rights of the villag'ers over the wastes into rights of user over the lord's soil. Questions like the origin and antiquity of manors, and the extent to which they prevailed before the Norman Conquest, have been to a great degree reopened br Mr. Seebohm's remarkable work, ${ }^{1}$ in which the legal theory is practically supported by an historical argument. But whether the relation of manors to village communities lepresented encroachments by the lord or advances by the serf, whether the rights of agrarian associations underlay or were acquired against the manorial rights of the feudal baron-whether, in other words, the land-law of the noble was becoming the land-law of

1 The Englist Tillage Community, London, 1853. 
the people or the reverse, is here immaterial. Ronghly and generally speaking, the immediate lordship of the land farmed by a village community, including the wastes and commons, was, after the Norman Conquest, vested in the lord of the manor, subject to regulated rights enjoyed by its members.

During the three centuries after the Conquest the manorial estate consisted of three portions-the demesne land, the villein's land, and the commons. The demenne land was originally intended for the lord's personal use; it was his ' board land.' It therefore constituted the smaller' portion of the total acreage. Thus in 12.2.2 the manors of St. Paul's contained 21,000 acres, of which three-eighths were in demesne. The demesne might be kept in hand and cultivated by the agricultural services of the peasantry; or let off in solid blocks to tenants, who also held land in the common fields; or cut up into strips and intermixed with other holdings of the villenage. "The distinction between the 'terra dominica' and the 'terra villanorum 'was that the first, if let out, might be resumed each season at will. but villein land was land of inheritance alienated in perpetuity on payment of certain praclial services. Thuns the lord of the manor might keep his demesne in his own hands, cultivating it as a home farm by the agricultural services of the peasantry; or he might be a modern landlord, letting it out to tenants in separate farms at an annual rent; or he might throw it into the farm of the township, and becone a shareholder with his tenants in the common venture of the Agrarian Association.

The mass of the rural population lived in hereditary subjection, holding land by labour-rent. Of this semiservile class, the villeins formed the aristocracy. The villein proper was no ordinary servant in husbandry, but, 
like Chaucer's ploughman, had 'catel' of his own. He was obliged to contribute, at the rate of an ox for each half-virgate, to the manorial plongh-team, which almost universally consisted of eight oxen. So tenacions was agricultural custom, that in the eighteenth century, whatever the soil or the weight of the plongh, few farmers ploughed with less than this number. Villeins were distinguished from the inferior orders of their class by this obligation, and their uncertain services were gradually limited to boon-days or precations, and finally commuted for moner. The continuous work of the farm fell to the inferior peasants, such as bordars and cottars, or actual serfs. The bordars were holders of a homestead, possibly a small croft of land near the village, and sometimes small pieces of the common arable fields. They aided the villein in cultivating the demesne, but were not owners of oxen. Their obligatory services were more continuous, more trivial, and more servile than those of villeins. Probably in actual labour the serf was not worse off than the bordar, and, like him, he might hold land; but his tenure was bondage, not prædial service. Out of these three orders sprang the small freeholder, the copyholder, and the wage-earning labourer.

The obligations of the peasantry varied not only with customs, but with seasons. Their most important services were the autumnal and Lenten seed-ploughings. Fallows were broken up abont Hoketide, and plonghed and dunged for sowing wheat and rye about Michaelmas. Land was ploughed for oats, barley, and peas, after Epiphany; the crops sown and harrowed in March or April. The ploughman held the principal hale of the plough in his left hand, in his right a beetle to break the clods. A 'Dover-court' beetle was a necessary implement upon a farm in the time of Tusser; and Plot, whose 'Natural History of Oxford- 
shire' appeared in the seventeenth century, recommends its use after the land was harrowed. On some manors harrowing was one of the services which the villeins associated to render. But the implement was of the lightest and rndest description. Fleta gives the amount of wheat sown to the acre as two bushels, and the average yield at ten to twelve bushels. But, except on the best land, so small a seeding was rare. 'The quantity of seed for barley, oats, or rye was far greater. Probably the labour of sowing was performed by the bailiff himself, as, at the beginning of this century, it was performed by the farmer with his own hand.' All seed was sown broadcast, and the land, which was generally wet and foul, was more. thickly seeded then than now. After the plots were sown and fenced, the hayward exacted a penalty from all trespassers, except messengers riding in haste. Corn was weeded in .June, for the maxim was ancient,-

Who weeds in May

Throws all away.

In the fourteenth century, on the 220 acres of Hawsted Manor Farm, in Suffolk, sixty sarclers or weeders were employed on one day at $2 d$. apiece. In dry weather they were armed with a hook and a forked stick, in wet with tongs.

Nothing is more characteristic of the infancy of farming than the violence of its alternations. When roots and grasses were unknown, there was no middle course between incessant cropping and barrenness. The fallow was ' un véritable Dimanche accordé à la terre.' As with the land, so with its products. Feasting trode on the heels of famine. In the graphic language of ancient chroniclers, parents in

${ }^{1}$ Professor Rogers, History of Agriculture and Prices, i. 16. 
1270 ate their own children when wheat rose to 336r. a quarter at the present value of money. Except in monastic granges, no quantity of grain was stored: a corn dealer was the ' caput lupinum' of the Legislature. Few remembered to eat within their tether, or to spare at the brink and not at the bottom. In August 1317 wheat was 80.s. a quarter; in September following it fell to $6 s .8 d$. In 15.57 the price of wheat was 53.. 1d.; after harvest it fell to ร.s. Equally variable were the employments of agriculture. Months of indolence passed suddenly into intense labour. Harresting's in the Middle Ages were picturesque scenes of bustle and of merriment among the thousands to whom they meant the return of plenty. On 250 acres in Suffolk, towards the close of the fourteenth century, were grown wheat, oats, peas, barley, and bolymong, a mixture of peas or tares, and oats. The crops were cut and housed in two days. On the first day appeared thirty tenants to perform theil ' bederepes,' and 214 reapers. On the second, the thirty tenants. and 239 reapers, pitchers, and stackers. Many of this assembly were the smaller peasantry on the manor; the rest were wandering bands of 'cockers' or harvester's, who had already begun to parade the commtry. A cook, brewer, and baker were hired to supply dinner at nine, and supper at fire. Barley and oats, as well as peas and beans, were generally mown; rye and wheat were reaped. But the harrest, as in Poman times, consisted of two operations : the first was to cut the ears, the second to remore part of the straw for thatching. But the value of the straw of thin short corn hardly paid for the expense of removal, and the rest of the stubble was either grazed, or burned, or plonghed in.

The proportion of arable land was greatly in excess of grass land. The crops of the former' were wheat, rye, oats, 
barles, beans, peas, and, in smaller quantities, flax and hemp. Roots or artificial grasses were entirely unknown. Of grain crops rye was the chief; it is the hardiest, grows on the poorest soils, makes the toughest straw. Rije was then the bread-stuff of the peasantry, as it still is in Northern Europe. It was generally mixed with wheatflonr. Bread so made was called maslin. ${ }^{1}$ It retained its moisture longer, and, as Mor'sson ('Itinerary', temp. James I.) says, was used by labourers becanse 'it abode longer in the stomach and was not so soon digested with their labour.' Wheat and rye were often sown together. 'Tusser condemns the practice, 'lest rye tarry wheat till it shed as it stand;' but it prevailed in Yorkshire in 1797 as a cure for mildew. $\mathrm{B}_{y}$ itself wheat was seldom sown. Barley was the drink-corn, as rye the bread-corn, of the Middle Ages; drage ${ }^{2}$ was the commonest and best sort for malting. Oats were extensively cultivated in the north; but they were grey-awned, thin, and poor. The culture of vines is often quoted to prove a change of climate in the England of 1888. But it must be remembered that wine was then sweetened and flavonred with hones and spices; it was never drunk in its pure state; and therefore no theory can be founded npon the production of a liquid which may have resembled vinegar in its natural state. Little manure was nsed. In arable farms all the dung produced was thrown on the 'infield;' the 'outfield' was neglected. The right of folding was valuable to lords of the manor' becanse their" own land was thus enriched by the temant's flock. Horses were scarcely nsed in agriculture. Oxen

' Lat. 'mixtilio.' Harrison, ' miscellin.' Yorkshire, 1797, ' mashelson.' In the 'Compleat Farmer' (1760) it is called 'maislen ;' but it is said to be 'ill-husbandry' to grow wheat and rye together.

2 Lat. drageum, dredge : bigge; bere barley. 
cost less, are shod only on the forefeet, do more on hilly ground; their gear and winter keep is less expensive: they are 'mannes meat when dead, while the horse is carrion.'

In the Middle Ages the monks both of England and of France were the pioneers of agriculture, and it was through their inflnence that marshes were drained, forests cleared, wastes reclaimed, and barren land reduced to cultivation. The 'strenuous idleness' of a baronial aristocracy revolted from farming. This contempt for bucolic life is illustrated by heraldry. Sport, war, religion, supply its emblems: agricultural implements and products are disdained till, like the garb of the Washbonrnes, the haywains of the Hays, the scythe of the Sneyds, they have heen ennobled by martial use. The monks studied agriculture by the light of Varro and Columella. But their influence was sometimes opposed to progress. Corn was indispensable to monasteries, and its growth was often compulsory on monastic tenants. As the natural pastures of La Bremne in Berri were sacrificed to the desire of grain, so the 'fat vale ' of Evesham was cut np into arable parcels, so small and scattered that no tenant conld lay his holding down to grass. That their love of ale induced monks to compel the cultivation of barley where oats were more profitable is probably a slander. From 1350 onwards the relations of owner and occupier assume a modern aspect; leases become common ; villenage and serfdom disappear : ont of the Black Death and the French wars arise tenant farmers, copyholders, free wage-earning labourers. The first half of the fifteenth century most nearly realised the peasant's dream of Arcadia. Rural life in the preceding period must be stndied, not in the holiday scenes of Chaucer, but in the realistic pictures of Langland. Between 1389 and 
1444 the wages of agricultural labourers doubled: harrests were plentiful; beef, mutton, pork, became their food: sumptuary laws against extraragance of dress and diet attest their prosperity : the standard purity of the coinage was steadily maintained, and the number of shillings into which the pound was coined varied only between thirty and thirty-five. Fortescue attribntes the success of the English against the French to the superiority of their diet. "The people,' he says, 'be wealthye, and have al thynges necessary to the sustenaunce of nature, wherfor thay be mighty, able to resrste the adrersaries of the realme, and to bett other realmes that do or will do them wrong.

A concrete instance illnstrates mediæval practices and the progress of the labouring classes. The Domesday Survey of the manor of Castle Combe in Wiltshire shows that the manor consisted of meadow, pasture, and arable land. The meadow was divided into strips held by the peasantry. The pasture, which was rough and wooded, was held in common. One thousand acres were under the plough, of which 400 acres were the lord's demesne, cultivated by thirteen serfs and labour-rents; the remainder was held by villeins, boors, and cottagers. The arable land was divided into two fields, North field and South field, among which were scattered twenty-five parcels of demesne land called 'dooles,' each comprising about four acres. There were no free tenants. In 1340 there were ten free tenants whose services were commuted for money payments, and who held between them 233 acres of arable land. The remaining tenants were still in bondage. Fifteen were customary tenants, holding 625 acres, partly by money rent and partly by labour services. Eleven other tenants held fifteen acres each by agricultural services; but in addition they held crofts, for which they paid rent in 
money. Eight 'Monday-men' held cottages and curtilages by labour-rent. These thirty-four tenants were all bondagers, but they could always commute their labour services at a money value, and provide substitutes. These they found in one another, or in twelve tenants of cottages who paid fixed rents. In 1352 all the labour-rents were commuted for money payments. In 1451 the 'dooles' of demesne land were let to five tenants who were responsible for the whole rent, though in practice they seem to have sublet. The customary tenants had increased to twenty; the Monday-men to fifteen. The manor was self-governing. The tenants elected the bailiff, the hayward, the sheep-teller, who counted the stock on the commons, the constables, ale-tasters, and other manorial officers. They also composed the 'leet-jury,' which disposed of small criminal offences, presented tavern-haunters or common idlers, made bye-laws regulating the maintenance of the merestones or butts, the repairs of the bridge or the sewers, the brewing and selling of ale and beer. And all this was done without the intervention of a lawyer or his fees. 


\section{CHAPTER II.}

FARMING FOR PROFIT.

THE end of the wars of the Roses synchronised with social and commercial changes which produced the first great agricultural crisis. Up to the Tudor period the mass of English land was tilled upon the plan already described, which foreign legislators of the nineteenth century found to be still prevalent on the Continent. Without discussing further the origin of manorial rights, it may be repeated that at the Norman Conquest the fendal manors were superimposed upon agrarian communities. Henceforward the land was divided into the private demesne of the lord of the manor, the lord's wastes, and the tenemental land of the association. Rights of common were exercised not only over the commons, the soil of which was now vested in the feudal lord, but by each party respectively orer the land of the other. If the lord of the manor farmed the demesne liimself, his land was subject to the rights of common exercised over it by the manorial tenantry. If he farmed his demesne as a modern landlord, he multiplied retainers by letting it out in small portions to farmers who were often holders at the same time of tenemental land. If he threw the demesne into the common stock, he made himself a partner in the joint venture of the agrarian association. Demesne and commonable land was intermixed and cultivated in minute strips. So 
confused did the two portions become that on the estates of the Dean and Chapter of St. Paul's three acres could not be found by the land registrars. For this reason Fitzherbert, in his 'Book of Surveying,' impresses on the surveyor the need of accuracy; lest 'any parcell be loste, or imbeselde, or encroached by one from the other.' But between 1450 and 1560 an agricultural revolution was accomplished, which may be briefly described as a change from self-sufficing to profit-gaining agriculture, from common to individual ownership.

The first steps in this change were taken when lords of manors enclosed their wastes, or withdrew their demesne lands from the agrarian partnership, or when the partners of village communities agreed among themselves to extinguish their own common rights over the arable fields. On most manors three distinct rights of common pasture were enjoyed. 'There is commonly,' says Fitzherbert, 'a common close taken in ont of the common fields by tenants of the same towne, in which close every man is stinted and set to a certaintie how many beasts lie shall have in the same.' This enclosure of land that it might be common belongs to a later date, and is comparatively unimportant. Secondly, common rights were exercised over the lord's wastes, ontwoods, moors, and heaths, 'which were never arable land,' and the soil of which was vested in the lord of the manor. Thirdly, rights of common were enjoyed over the land that lay fallow in rotation and over the common arable lands from harvest to seed-time, 'the plain champaign countrie,' to quote the words of Fitzherbert, 'where their cattle lie claily before the herdsmen.'

These are the rights of 'parcours' and 'vaine pâture,' which, in France, remained for centuries insuperable obstacles to agricultural progress. Upon the second and third 
class of rights depended the prosperity, if not the very existence, of agrarian associations; they afforded the only means of keeping live stock. It may be doubted whether, before 1236, lords of manors could by common law enclose wastes subject to rights of common; but, be this as it may, in that jear the Statute of Merton sanctioned enclosures against all freeholders whose rights of common were derived from the owner of the soil. Fifty years later the right of enclosure was extended by the Statute of Westminster against commoners whose right was not derived from the lord of the manor. 'Many of the lordes,' says Fitzherbert at the begiming of the sixteenth century, "have enclosed a great part of their waste grounds, and straightened their tenants of their common therein.

The example of the landlord was often followed by the principal partners of the village farm. During the same period numerous agreements were entered into between the commoners to extinguish, temporarily or permanently, the right to graze the arable lands from harvest to seedtime. 'Licenses' were given to the tenantry 'to enclose part of their arable lands, and to take in new intakes or closes out of the commons.' Finally, lords of manors withdrew and enclosed their demesne lands which lay in the common fields. thus still further curtailing the right of common pasture. Fitzherbert says that, before 1530 , 'the mooste part of the lordes have enclosed their demeyn landes and meadows, and kept them in severalties, so that their tenauntes have no common with them therein.'

This agricultural change was accelerated by a social and commercial revolution. The Hundred Year's' war maintained the external features of a system which was completely undermined. It is this fact which gives the air of hollowness and artificiality to the reign of 
Edward III. The feudal organisation of society was breaking up; land was regarded as a source not of power, but of wealth. The tendency set in strongly towards small convertible arable farms; tenants withdrew from the common farm of the township, and exchanged their scattered strips for solid tenements of from 10 to 120 acres; landlords found self-farming unprofitable, and divided their demesnes into small holdings let on lease, when agricultural services were commuted for money, and the Black Death had raised the rate of wages.

The withdrawal of the English landlord from the agrarian partnership exactly corresponds to the process which took place in the present century on the Continent. It was a change from common to individual ownership; land was divided between the lord of the manor and the association; rights of common, mutually enjoyed, were extinguished. In its results, manorial estates were consolidated, partly by withdrawal from the village farm, partly by the enclosure of wastes, and many of the agrarian associations were broken $\mathrm{np.} \mathrm{When} \mathrm{these} \mathrm{partner-}$ ships were dissolved, common-field farmers enclosed their strips and became peasant proprietors. Where the association lingered on, its farming steadily deteriorated, as well from the contraction of the area of the common farm as from the neglect of the 'field constraint' which had been mainly enforced by the landlord's officers. Yeomen were little affected by a change which slightly increased their numbers. The two classes that eventually suffered were the 'common-field farmers,' to use the eighteenth century description, and the cottagers or emancipated serfs, who had no share in the lands of the agrarian community, but lived as hired labourers, supplementing their wages by keeping cattle on the rough 
pasture. The change was at first advantageous to all the classes concerned. Wage-earning labourer's obtained more constant employment, while more substantial farmers reaped advantages from the consolidation of their holdings. Such enclosures were warmly recommended by practical agriculturists like Fitzherbert, who advises every man to 'change fields with his neighbour, so that he may lay his lands together,' keep more cattle, improve the soil by their 'compostynge,' and rest his corn land when it becomes impoverished. A new conception of agriculture dawned on men's minds. Landlords recognised that the soil might produce rents now that they had ceased to need retainers; farmers were no longer content to produce enough for their own families, but desired to become growers as well as consumers. It is significant that the earliest corn laws were passed in the reign of Henry VI. Legislation to maintain the value of corn begins in 1436, and in 1463 foreign imports were forbidden ${ }^{1}$ until prices reached the point at which export was prohibited.

But it was not long before commercial interests gave a new direction to agricultural tendencies, which proved fatal to the lower ranks of the labouring or land-holding population. The wars of the Roses were the suicide of feudalism, and in the reign of Edward IV. the spirit of trade breathed freely throughout England. If farmers were slow to recognise that 'the foot of the sheep turns sand into gold,' merchants were quick to see that money might be made by the growth of wool. But sheep could not be herded with success upon commons, and small holdings were incompatible with large flocks.

1 No corn was to be imported until wheat was $6 s .8 d$, rye $4 s$, barley $3 s$. the quarter. These prices must have been high. (See table of prices of wheat, Appendix I.) 
The growth of woollen manufactories raised the price of English wool, which commanded the market at home and abroad. Edward III. encouraged Flemish woolworker's to settle in England and improve domestic manufactures, which hitherto had aspired to nothing more than a coarse frieze. He settled his Flemings in every part of England, but especially in the eastern counties and the south-west. At the same time English wool was indispensable to the manufacturers of Flanders, who mixed it with the produce of Spain, so that Europe was clothed by English farmers. Wool was easy of transport, little liable to damage, subject to no duties. Baltic corn, on the other hand, competed successfully with English grain in foreign markets; as a merchandisable commodity corn was liable to every tax and damage. Arable farming was expensive and uncertain; sheep-feeding sure and cheap.

The high and certain profits of sheep-farming encouraged not only the consolidation of holdings, but a revolution in agricultural practice. Hitherto but little attention had been paid to grass farms. Now tillage gave way to pasturage. The new commercial aristocracy converted their land into parks or sheep-walks, where only a shepherd found employment. They encroached upon and enclosed the commons by force or connivance with the principal commoners. The purchase of common rights must have been rare, for in the reign of Edward VI. the Statute of Merton was re-enacted. Tenants were encouraged to consolidate their holdings, to exchange open fields for separate farms, to divide the common pasture with the landlord. Small tenants were evicted from their holdings on the demesne; farm servants who had boarded with them were dismissed; the cottages of the married 
labourers were pulled down. At the same time wastes and commons were enclosed and thrown into sheep farms. This contraction of the area of rough pasture inflicted a second and fatal blow on the interests of the small cottagers. The Statutes of Merton and Westminster only protected the interests of the freeholders, and so long as their consent was obtained no rights were recognised in other classes. The dissolution of the monasteries stimulated the process. The new landlords treated the rojal grant as an excuse to orerride the customary and common rights of the existing tenants. The doggerel ballad ("Tox Populi Vox Dei, 1519) laments the change:-

WVe have shut away all cloister's,

But still we keep extortioners;

We have taken their lands for their abuse,

But we have converted them to a worse use.

Legislation was powerless to check the reaction against tillage; it failed to compel landlords to limit their flocks and maintain their farm buildings. The main object of the Gorernment was to prevent the depopulation of the country ; $^{1}$ but exemptions were purchased from the restraining statutes, or their provisions were evaded. The destruction of farm buildings was forbidden, but it was easy to retain a single room for the shepherd; a solitary furrow diviven across newly laid pasture satisfied the law that no fresh land should be converted from tillage; the number of sheep was limited by law, but flocks were held in the name of sons or servants. A petition in the reign of Henry VIII. states that 50,000 ploughs had been put down, each of which, on the average, maintained $13 \frac{1}{2}$ persons. Thus, 675,000 persons were thrown out of work

1 See Appendix II. 
when the whole population of the country did not exceed five millions. Still more vain was the quaint pedantry of the law which gave arable land the precedence over all other lands, conferred privileges on beasts of the plongh above other beasts, voided bonds to restrain tillage. 'Depopulatores agrorum' were denied the benefit of clergy, sanctuary, or Christian burial. In spite of every effort, England remained till the eighteenth century the sheepfeeding country she had become under the Tudors.

Advanced free traders might agree with Raleigh that England, like Holland, could be wholly supplied with grain from abroad withont troubling the people with tillage. Many, however, looked no further than the immediate distress which these changes produced. Wageearning labourers were thrown out of employment, tenant farmers were evicted from their holdings ; crowds of small seomen, copyholders, and cottars, who had eked out their livelihood by the produce of the stock which they maintained on the commons, were ruined. John Rous, the monk and antiquary of Warwick, was the first to protest against the conversion of the country into a wilderness, traversed only by shepherds and their dogs. Pole, Brinklow, More, Bacon, Strype, declaimed against a system which Latimer and Gilpin denounced from their pulpits. The cry of the people disturbed the learned quiet of Ascham, reached the ears even of Somerset and Edward VI. 'Their distresses broke to the surface in the numerous agrarian insurrections of the century. The sweating-sickness claimed its thousands; famine, rot, and murrain prevailed continnously. The high prices of necessaries, combined with the loss of commons and bad seasons, drove the small proprietors over the narrow border which separated them from starvation. Rents rose exorbitantly, till, for farmers 
at rack-rent, existence was a misery. There was an ominous growth of middlemen, "leasemongers, who take groundes by lease to the entente to lette them againe for donble and tripple the rente,' who battened on the earth-hunger of the people. In the reign of Henry VI. the average price of wheat was $6 s .8 d$. a quarter, of rye $4 s$., of barley $3 s$. The daily wages of labourers without food from Easter to Michaelmas were $4 d$. Thus the labourer could then earn a quarter of wheat in 20 days, of rye in 12 days, of barley in 9 days. In 1595 the price of wheat was $20 s$. a quarter, of rye $13 s$. $4 d$, of barley $12 s$. In the same year the wages of labourers were fixed by the Yorkshire justices at $5 d$. a day without food, from March 1 to November 1. Thus labourers could then earn a quarter of wheat in 48 days, of rye in 32 days, of barley in 28 days. Even those labourers who found employment worked for less wages than they received in the preceding century. They were compelled to accept the rate fixed by the employers; the arguments were whipping, branding, the galleys, or death. Thousands besides 'poor 'Tom' were whipped from 'tything to tything, and stock'd, punish'd, and imprisoned.' Legislators were bewildered by currency questions. Violent changes in the coinage aggravated distress. The nominal value of wages remained stationary while the purchasing power rapidly diminished. The standard purity of the pound of silver was, in the reign of Henry VIII., 18 dwts. of alloy to $11 \mathrm{oz}$. 2 dwts. of silver. The pound of silver was coined into 45 shillings. In the fifth year of Edward VI. there were $9 \mathrm{oz}$. of alloy to $3 \mathrm{oz}$. of silver. The pound of silver was coined into 72 shillings. In other words, the ounce of silver varied between 3s. $9 d$. in 1509 and 24s. in 1552. The standard of purity was restored in 1553 , only to be again 
debased by Mary, and again restored by Elizabeth. As. gold and silver poured into Europe from America prices rose throughout Europe. The rise was in England attributed to every cause but the true one, which was the lowering of the value of the precious metals. From 1459 to 1560 wheat areraged $9 s .2 d$. per quarter; from 1561 to 1601 it averaged $47 . . \check{c} d$. But while the purchasing power of money was thus diminished, legislation prevented wages from following the rise in prices. Only human life was cheapened. The labour market was glutted; guild jealousies excluded peasants from trade. The poor-laws were passing from voluntary almsgiving to the compulsory support of the poor. There was no substitute for monastic bounty. Shakespeare drew no fancy picture, but one of which 'the country gave him proof and precedent,' of the 'bedlam beggars' who

\section{from low farms,}

Poor pelting villages, sheepcotes, and mills,

Sometime with lunatic bans, sometime with prayers,

Enforce their clarity.

Meanwhile large farmers profited by the low wages of agricultural labour and the high prices of agricultural produce. While Latimer laments the degradation of small yeomen, who, like his father, had farms of 'three to four pounds a year at the uttermost,' Harrison describes the rise of substantial farmers and the middle classes, and the chimneys, beds, sheets, pillows, pewter, tin, and silver, which for the first time appeared in their houses.

The process by which the commons were enclosed was often high-handed and oppressive. From the comparative silence of English records it cannot be concluded that a parliament of English landlords had no occasion to protect the interests of the cultivators of the soil. Sir Thomas 
More speaks of 'husbandmen thrust out of their own, or else, by covin and frand, or by violent oppression, put beside it, or by wrongs and injuries so wearied, that they be compelled to sell all.' The proceedings of Sir Giles Overreach in the 'New Way to pay Old Debts' did not entirely originate in the brain of the dramatist, and the peasant proprietor of a Naboth's vineyard would fall an easier victim than a lord of the manor.

I'll buy some cottage near his manor,

Which done, I'll make my men break ope his fences,

Ride o'er his standing corn, or in the night

Set fire to his barns, or break his cattle's legs.

These trespasses will draw on suits, and suits expenses,

Which I can spare, but will soon beggar him.

When I have harried him thus two or three years,

Though he sue in form $\hat{\imath}$ parperis, in spite

Of all his thrift and care he'll grow behindhand.

Then, with the favour of my man at law,

I will pretend some title : want will force him

To put it to arbitrament. Then if he sells

For half the value he shall have ready money,

And I possess the land.

But forcible enclosures of wastes or encroachments by squatters were not the only means by which common land passed into individual ownership. Voluntary agreements. between commoners and proprietors of land were frequent, and bargains were often struck on eqnitable terms. Instances like the following extract from Kennet's 'Parochial Antiquities ' (ii. 324) might be indefinitely multiplied :

'The said Edmund Rede, Esq., granted and confirmed to Thomas Billyngdon one close in Ardyngrave, in consideration whereof the said Thomas Billyngdon quitted and resigned his right to the free pasturage of four oxen to feed with the cattle of the said Edmund Rede and all 
right to any common in the said pasture or inlandys of the said Edmund.'

Here in the England of 1437 was the principle of commutation of rights of common applied by private contract. Sometimes these bargains were sanctioned by the Court of Chancery, or, where the Crown was interested, by royal license. No parliamentary confirmations are to be found before the reign of Charles II. Each party to the private contract possessed his block absolutely, instead of enjoying a perplexing variety of cross rights. Browbeating and bullying doubtless occurred, but attempted acts of oppression were frequently checked by the courts of law. Justice was not always perverted in the interests of landlords, nor were matters always ' ended as they were friended.' An interesting account of the attempted enclosure of the common fields at Welcombe, near Stratford-on-Avon, has been recently published by the late Dr. Ingleby, the wellknown Slakespearian scholar. It is contained in a fragment of the private diary of Thomas Green, town clerk of Stratford in the first years of the seventeenth century. William Combe, lord of the manor of Welcombe, desired to enclose a portion of the hamlet which from time immemorial had been common fields. Lord Chancellor Ellesmere was an interested promoter of the scheme. Among the persons possessing riglits over these common fields was William Shakespeare, who appears to have resisted their enclosure. Upon the petition of the commoners at Warwick Assizes, Chief Justice Coke made an order that ' noe inclosure shalbe made within the parish of Stratforde, for that yt is agaynst the Lawes of the Realme.' 


\section{CHAPTER III.}

\section{THE SEVENTEENTH CENTURY.}

But though the change from common to individual ownership, from self-sufficing to profit-gaining agriculture, was accompanied with wide-spread distress, the sixteenth century, especially towards its close, witnessed a general impulse to the study and practice of farming. It was now that Herrera in Spain, Tarello in Italy, Heresbach in the Low Countries, Charles Estienne and Bernard Palissy in France, wrote upon agriculture. The gentry began to pay attention to farming. As Michel de l'Hôpital solaced his exile from court with his farm at Etampes, so Fitzherbert relieved his judicial labours with the cultivation of his land.

With the Tudor period begins the agricultural literature of England.' Besides Fitzherbert and Tusser, there were Turner, Googe, Sir Hugh Plat, Plattes, Markham, and others. 'Mayster Fitzherbert's Boke of Husbandry' was 'imprynted in 1523,' and in the same year appeared his 'Boke of Survering.' The reputed author, a judge of the Common Pleas, treated his subjects in the most practical manner. His theory of the origin of the fluke in sheep survives in a more scientific form at the present day. The prevalence of the rot disquieted other agricultural writers. Harrison attributes it to 'gossamers, rowty fogs, mildews, and rank grass.' Leonard Mascall, who wrote on

1 Appendix III., The early literature of agriculture. 
the 'Govermment of Sheepe' in 1605, warns shepherds against plants grown 'on wet and marish grounds.' Tusser is the poet of agriculture. He embodies his experiences in doggerel verse, without any invocations of Pomona or Ceres. In his own life he illustrated the difficulty of combining the practical farmer with the contemplative poet. 'He spread his bread,' says Fuller, 'with all sorts of butter, yet none would stick thereon.' He was successirely 'a musician, schoolmaster, serving-man, hnsbandman, grazier, poet-more skilful in all than thriving in his vocation.' His book was long recognised as a useful guide to farmers. In 1723, Lord Molesworth proposed that schools of agriculture should be established, in which 'Tusser's work should be taught to the boys to read, to copy, and get by heart.' Now it is only valuable as a storehouse of information respecting the domestic economy and rural life of our Elizabethan ancestors. Clover and artificial grasses were unknown to Tusser and Fitzherbert: the former mentions turnips as ' a kitchen-garden root to boil or butter.' Both advocate enclosures, and instance Essex and Suffolk to prove the superior cultivation under the newer system. Tusser's testimony that, in these two counties, beef and mutton were more plentiful, cheese and butter better, and all classes wealthier than elsewhere, is the more striking, as he was an Essex man and a Suffolk farmer. The proverbial 'Suffolk stiles' seem to point to the early extinction of parish fields; but both counties partily owed their pre-eminence to the possession of some of the highways between the Netherlands and London. Chaucer's merchant demands that the sea be kept clear between Orewell and Middleburgh. Yet it is significant that Fitzherbert and Tusser, representing the best theory and practice of agriculture of their day, ignore draining 
and dismiss manure or 'compass' with the briefest possible mention.

At the end of the seventeenth centmry the prospects of agriculture seemed brightening. As Hartlib, the friend of Milton and pensioner of Cromwell, puts it, 'ingenuities, curiosities, and good husbandry began to flourish.' 'The soil,' says Harrison, 'had growne to be more fruitful, and the countryman more painful, more careful, and more skilfnl for recompense of gain.' Wheat averaged ' on the welltilled and dressed acre' twenty bushels. Improved means of communication facilitated progress. Increased attention was paid to manuring. In Sussex, farmers purchased lime, fetched it from a distance, and burned it in kilns erected for the purpose. In Middlesex and Hertfordshire the sweepings of the London streets were bought up for the fields. In Cornwall, farmers rode many miles to get sand, and brought it home on horseback. In Sonth Wales seaweed was extensively used. New materials for agricultural wealth accumulated, especially throngh the revival of gardening. Since the wars of the Roses this art had nearly expined. Herbs, fruits, and roots, which had been plentiful in the fifteenth century, had died ont, or were thrown to the pigs. Even in 16.50, Hartlib says that gardening was hardly known in the north and west of England. Hops were introduced into England in the reign of Henry VIII, thongh the old rhyme is hardly correct which says,-

Hops, reformation, bays, and beer

Came into England all in one year.

They were extensively cultivated in Suffolk in the time of Thsser. Onions, cabbages, carrots, parsnips, ' colleflowers,' were chiefly imported from Flanders; though Piers Plowman could command the two former vegetables, they were 
now rare except about Fulham and the Suffolk coast. Carrots were called Sandwich carrots, after the chief place of their cultivation. Turnips were scarcely grown except in gardens near London. Potatoes were still exotics, and luxuries of the rich. Both turnips and clover are urged on English farmers by Elizabethan writers. Googe, who knew the Low Countries, calls clover 'trèfle de Bourgogne,' aud, after Heresbach, supposes it to be a Moorish grass, brought in by the Spaniards. In the same anthor's mention of a car armed with sharp sickles may be traced the first hint of the reaping machine.

The civil wars checked agricultural progress. Husbandry, if it did not actually decline, languished. It was a period of extreme distress. In 1651 Blith says that the poor farmers 'lived worse than in Bridewell;' Hartib adds that but for foreign supplies the people must have starved. Wheat rose rapidly, till in 1648 it stood at $85 \mathrm{~s}$. the quarter. This rise was due to the deficiency not only of harvests, but of arable land. The average price from 1647 to 1651 was $77 \mathrm{~s} .7 \mathrm{~d}$.; the arerage taken from 1647 to 1700 was only $49 \mathrm{~s}$. 10d. Hartlib calculates that, in Fngland and Wales, not more than four million acres were under tillage. While beef and mutton also rose to $3 \frac{3}{4} d$. per pound, daily wages withont food advanced only $1 d$. upon the $3 d$. of 1444 .

On the other hand, the materials of agricultural wealth rapidly accumulated, and the work of preparation continued almost uninterruptedly. To Sir Richard Weston, of Sutton in Surrey, formerly ambassador in the Palatinate, belongs the credit of the first successful cultivation of turnips and clover, the pivots of English agriculture. As Brillat-Savarin valued a new dish above a new star, so Young regards Weston as a 'greater benefactor than 
Newton.' He did, in fact, give bread to millions. Blith and Hartlib followed him, but it was long, as the latter says, before clover emerged from 'the fields of gentlemen into common use.' Hartlib urges the adoption of roots and the folding of sheep, 'after the Flaunders manner,' as a means of improving sandy commons. He continually advocates the use of clover and 'Holy Hay or Saint foine,' and gives space to the following advertisement: "Such as are desirous to buy any of the three-leaved grass, or" lucern, spurry, clover-grass, and sinke-foile, what quantity they please, may have them at Thomas Brown's shop at the Red Lion in Soper Lane.' Twenty years later, Plot mentions clover and sainfoin among the unusual grasses cultivated in Oxfordshire. In 1669 Worlidge, after advocating enclosures and the cultivation of artificial grasses, urges turnips on farmers, 'although this be a plant usually nourisht in gardens and be properls a gardell plant.' Still more explicit is Houghton (168?); he says that 'some in Essex have their fallows after turnips, which feed their sheep in winter, by which means their land is dung'd as if it had been folded; and these turnips, tho' few or none be carried off for humane use, are a very excellent improrement.' On the other hand, Blith derides turnips, which, he says, are only eaten by swive after they have been boiled.

Drainage was ably discussed by Blith. Writing as ' a lover of ingenuity,' he published his 'English Improver' in 1641. In 1652 a third edition of the work was published, under the title of 'The English Improver Improved.' In the interval Blith had become a captain and a courtier, and dedicated his book to the 'Right Honourable the Lord General Cronwell.' As remedies for the miseries of the agricultural population, he suggests the employ- 
ment of more capital, the abolition of 'slavish customs,' the recoguition of tenant right, the extinction of 'vermine.' Above all he insists on the necessity of drainage. It is characteristic of the age that he supports his argument from the Bible, and asks with Bildad, "Can the rush grow without mire, or the flagg without water?' Blith deals not only with surface water, but the constant action of stagnant bottom water. No drain conld, he said, touch the 'cold spewing moyst water that feeds the flagg' and rush,' unless it was 'a yard or four feet deep,' provided with proper ontfalls. His views are sound and advanced on a general scheme for drainage, in which landowners should be compelled to join for 'the commonwealth's advantage.'

When Blith wrote the drainage of the fens was a question of importance. The fen district was seventy miles long, in places thirty miles broad, and covered 680,000 acres. This was not land which had been under water since the Flood. Thorney was, in the time of William of Malmesbury, rich in vineyards and orchards, well wooded, productive, 'a rery paradise of pleasure and delight.' 'The drainage works of the Romans had been carried on by the monks of Thorney, Crowland, Ramsey, Ely, Spinney. But latterly they had fallen out of repair. The district is naturally drained by the Cam, the Ouse, the Nene, the Welland, the Glen, and the Witham. But it was only in the maps that they ran into the sea. The river-beds were foul, the channels choked; the streams continually overflowed their banks. Twice a day tides drove back the fresh water, and prevented the discharge of the mpland streams. The outfalls of the rivers silted up so rapidly, that in 1635, at Skirbeck Sluice, near Boston, a smith's forge and tools were found buried under sixteen 
feet of deposit. The country had thus become one vast deep fen, 'affording little benefit to the realm other than fish and fowl, and overmuch harbour to a rude and almost barbarous sort of lazy and beggarly people.'

The first drainage work of comparatively modern times was the cut from Peterborough to Denver, which, under the name of Moreton's leam, commemorates the famons Bishop of Peterborough. The whole district was surveyed at the close of the reign of Elizabeth, but it was not till 1606 that the first local Act was passed to reclaim the ring of Waldersea and Coldham. In 1630 the Earl of Bedford with thirteen gentlemen adventurers undertook to drain the southern fens. Though the Bedford level was the most completely executed work, the appliances could not cope with the rainfall of a wet season. Windmills were used to raise the waters of the interior districts to the level of the main river' Hartlib speaks of a 'Holland mill for dreyning set up at Ely, and kept by a certaine Frenchman.' But these clumsily constructed mills were inadequate. The work was partly done by Scotch prisoners taken at the battle of Dunbar, or by the Dutch prisoners of Admiral Blake. Other parts of the fens were in the same way partially reclaimed; others remained untonched till the present century. In some parts the works were never completed, or fell into decay, or were carried ont by persons whom Blith characterises as 'mountebank engineers, idle practitioners, and slothful, impatient slubberers.' In many districts the mills and embankments were destroyed by the fenmen. The following stanzas are quoted from the doggerel poem of some fen Tyrtæus :-

Come, brethren of the water, and let us all assemble, To treat upon this matter which makes us quake and tremble; 
For' we shall rue it, if ' $t$ be true, the Fens are undertaken, And where we feed in fen and reed, they'll feed both beef and mutton.

The feathered fowls have wings to fly to other nations, But we have no such things to help our transportations ; We must give place (oh grievous case !) to hornéd beasts and cattle,

Except that we can all agree to drive them out by battle.

Wherefore let us entreat our ancient water nurses

To show their power so great as t' help us drain their purses, And send us good old Captain Flood to lead us out to battle, Then Twopenny Jack with scales on 's back will drive out all their cattle.

Owing to the inadequacy of the original works, and the 'riotous letts and disturbances of lewd people,' the east fen became once more a shaking bog or a chain of lakes fringed with reeds. The Wildmore and west fens were in 1793 so wet, that ' 40,000 sheep, or one per' acre, rotted every year.' On Lindsey fen, in 1750, 'cows foraged midrib deep in water, swimming to their pasture from their hovels, and returning in the same way, and sheep were conveyed to pasture and clipped in flat-bottom boats.'

It is somewhat curious that foreigners should have taught the English the treatment of water. The Dutch drained our fens; paring and burning, irrigation, warpping, canals, are all foreign importations. A colony of French emigrants, settled near Thorney, introduced paring and burning, and the paring plough was long known as the French plough. The irrigation of meadows is said to have been first practised in modern times by the notorious 'Horatio Pallavazene,... who robbed the Pope to pay the Queen.' Warping was brought from Italy 
to the island of Axholme in the eighteenth century, and by its means the peaty soils at the mouth of the Humber were converted into 'polders.' The great 'Canal du Midi' was completed in 1681, but for nearly a hundred years its example was lost on England.

Before the Revolution the country, as has been seen, possessed the means of recovering its strength and indefinitely increasing its productiveness. Enclosures facilitated the progress of improvements. New methods of cultivation were studied, new crops introduced from abroad. Turnips offered winter keep for cattle; with cultivated grasses, they supplied the means of enriching sands now profitable only as rabbit warrens: the same discoveries prevented the waste of land by exhaustive cropping and subsequent idleness under fallow. Drainage had been more practically discussed than it was destined to be again till the time of Smith of Deanston. The burdens of feudal tenures had been removed. Though the Crown had reasserted its forest rights, the wild boar and the wolf disappeared in the reign of Charles II. But farmers were slow to profit by their improved position or to adopt new methods. No one, as Hartlib says, dared attempt innovations, lest he should be called 'a projector.' Little advantage was taken of the discoveries of experimental farmers; no general improvement was effected on the agriculture of the Georgics; no grazier formed a truer standard of the shape of cattle than Virgil or Columella. 


\section{CHAPTER IV.}

AGRICULTURAL PROGRESS IN THE EIGHTEENTH CENTURY : TURNIP TOWNSHEND AND THE NORFOLK SYSTEM.

THE gigantic strides by which agriculture has adranced within the present century dwarf previous progress into insignificance; but the change between 1700 and 1800 was astonishing. While population doubled itself, the number of persons engaged in agriculture decreased not only relatively, but, up to 1770 , actually. Before the end of the reign of George III. more than $6 \frac{1}{2}$ million acres of land were enclosed. The area under cultivation had increased, but not in proportion to the growth of population; but the difference between the two does not alone measure the increased productiveness of the soil. England not only produced food for a population that had donbled itself, and grain for treble the number of horses, at a greatly reduced expenditure of labour, but during part of the period was, as M. de Lavergne says, the granary of Europe. From 1700 to 1764 the standard of living among all classes was considerably raised. The discovery of silver had spent its force, and the value of the precions metals hardened. But the coinage was greatly debased. Consequently there was a great inflation of nominal prices, which dissatisfied consumers without benefiting prodncers. But this difticulty had been successfully met by the statesmanlike action of the Government of William III. Population increased 
more slowly than the productireness of the soil; poor rates fell below the figures of the preceding century; real wages were higher than they had been since the reign of Henry VI. Harvests were continuously prosperous; wheat, in spite of large exports, averaged, between 1713 and 1764, 34s. 11d. a quarter. There was little civil war or tumult, no rapidly increasing class of artisans, no glut of the labour market. Living improred among all classes. Instead of "Martylmas beef, the salted carcasses of half-starred oxen, 'euyll for the stone and euyll of digestyon, fitter' to be used outside as a waterproofe than inside,' fresh meat was eaten by the peasantry. Wheaten bread ceased to be a luxury of the wealthy; rye was now chiefly grown as a forage crop. The oaten loaves of Lancashire only survived in the proverb 'That's noan jannock.' The barley meal of Cumberland gave place to wheaten flour. In 1760 wheat was the breadstuff of fire-eighths of the population. The only drawbacks to agricultural prosperity were the 'most noted sheep rot' of 1735 , and the cattle plague which broke ont in Bohemia, derastated the north of France, and visited England three times during the period. Here the only remedy was to slanghter infected animals; the Government, paying one-third of the ralne, expended $135,000 l$. in a single rear. The period was tasteless, coarse, and apathetic; but it was the golden age of the English peasant.

The next half-century witnessed a complete change. The Poor Law of 1733 had checked population. Cottages were razed to the ground, lest they should become 'nests for beggars' brats.' But no impediments conld resist the effects of the prosperity of the previons period, or of the development of tracle. Population sprang up with a bound ; war' raised necessaries to famine prices ; bread, meat, cheese, beer, candles, were trebled; only clothing was cheapened. 
The climate worsened after 1764 ; the mean average rainfall from 1741 to 1750 was $18 \frac{1}{2}$ inches; from 1771 to 1780 it averaged 26 inches. The harvests were as unprosperous as they had previously been farourable; the imports of grain exceeded the exports. In no part of the country did the purchasing power of wages rise with prices. The aliowance system set a premim on large families, and so fostered the evil it was designed to alleviate. It was now that the South fell hopelessly behind the North. Before 1770 the rate of wages was lower in the North than in the South; now the position was reversed. Wages remained stationary in the South, eked out by mischierons allowances; while in the North they followed, though irregularly, the rise of prices. The introduction of machinery threw crowds of artisans out of work; the enclosure of commons again ruined thousands of small freeholders and copyholders. After 1814 the heary fall of prices produced severe distress among landlords and tenants. Two years later the Board of Agriculture sent a circular letter throughout the counties to ascertain the state of the kingdom. The answers showed that landlords reduced their rents 2.5 per cent., struck off arrears, gave farms rent free for a year; that still great quantities of land were thrown up ; that improrements were at a standstill, live stock decreased, and the country was filled with gangs of depredators; that everywhere 'bankruptcies, seizures, executions, imprisonments, and farmers become parish paupers,' were numerous. It is an extraordinary proof of the elasticity of the comntry that within ten years the social balance was restored.

The exertions of men like Townshend, Bakewell, Young, and Coke enabled farmers to meet the wants of a growing population. With their names is associated the agricul- 
tural progress of the century, which is comprised in improved methods of cultivation, the reduction of stockbreeding to a science, the enclosure of common field farms, the reclamation of commons and wastes, increased facilities of communication and transport, the invention of new implements, the application of new manures, the enterprise of capitalist landlords, the diffusion of intelligence among farmers. Within the period in question a class grew up which earned high wages and could afford to. purchase farm produce. But for this wage-earning artisan class, agriculturists would have remained content to satisfy uheir own wants. The crisis at home and abroad gives peculiar interest to the advance of agriculture. England was sharing in that industrial movement which culminated politically in the rise of the new republic of America and the downfall of the ancient monarchy of France. It is more exciting to watch the political earthquake on the Continent; but it is more satisfactory to trace the peaceful operations of nature by which the face of society was changed in England. To measure the influence of agriculture upon the two movements is impossible; but here, at least till the close of the century, there was no gap between it and the general advance of industry.

After the English revolution a new stimulus had been given to arable farming. The exportation of British wool was forbidden, and home manufacturers could not take up the supply. At the same time duties were laid on foreign wheat, and bounties were offered for the export of corn. ${ }^{1}$ Farmers

Bounties on exports :-

1. From 1697 to $1706,1,668,904$ quarters of wheat, barley, oatmeal, malt, and rye were exported, which were valued at 1,874,994l. 10s. $6 d$.

2 . From 1706 to $1726,8,134,196$ quarters were exported, valued at $8,429,704 l .14 s$.

3. From 1726 to $1746,9,488,703$ quarters were exported, valned at $10,080,2247.78 .3 d$. 
were thus attracted back from pasture to tillage. The wars which ravaged the Continent and prevented foreign nations from sowing or harvesting their crops completed what domestic policy initiated. It was at this crisis that Lord Townshend began the Norfolk or four-comrse system of husbandry, long the model for all other connties. Townshend s political career had been useful, and from 1709 to 1730 he had held important offices of State. In his capacity of Secretary he had accompanied George I. to Hanover, where he had seen turnips grown as a field crop. In 1730 lie abandoned to Walpole the exclusive enjoyment of power, devoted himself to farming; and, by causing 'two ears of corn to grow where but one grew before,' earned a bettel title to national gratitude than the whole generation of his political contemporaries put together.

Hitherto Suffolk and Essex had afforded the best examples of English farming. Suffolk was famous for its breed of Suffolk Punches, short compact horses, of about fifteen hands high, properly of a sorrel colour, unrivalled in their power of dranght, though, as Cullum wrote in 1790 , ' not fitted to indulg'e the rapid impatience of this

In the 1 st period $552, \$ 67$ quarters of wheat were exported.

, 2nd period 2,518,213

, 3 rd period $4,461,337$

"3

"

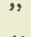

"

",

,

4. Between the years $1746-65,2,699,224 l$. 11s. $4 \frac{3}{4} d$. were paid in bounties on the following exports:-(1) Wheat, 6,800,016 qrs.; (2) barley, 1,26S,087 qrs.; (3) oatmeal, 67,186 qrs.; (4) malt, 4,977,303 qr's.

(5) rye, 939,580 qrs.

In the whole period, 1697-1765, it is calculated that upwards of 33 million quarters were exported, the valne of which exceeded $36,000,000 \mathrm{l}$.

Burke's Act of 1773 reversed the old policy of bounties, and, before it was modified, England had become a consumer rather than a grower of corn. See Appendix $1 \mathrm{~V}$. on the Corn Laws and the note there given on Bounties for Corn. 
posting generation.' It was famons also for its dairy produce, especially its cheese, "so hard that pigs grunt at it, dogs bark at it, but none dare bite it.' The mystery of its interior fired Bloomfield to sing of the Suffolk cheese which

Mocks the weak effort of the bending blade,

Or in the hog-trough rests in perfect spite,

Too big to swallow and too hard to bite.

The sonthern part of the county was chiefly held in small farms, crltivated with the care and neatness of 'la petite. culture.' Hollow drainage was practised earlier in Suffolk and Essex than elsewhere. The drains were wedge-shaped, filled with hazel bonghs, bullocks' horns, ropes of twisted straw, stones, or peat. Bradley (1727) speaks of the Essex practice of making drains two feet deep at close and regular intervals thronghont a whole field, filled with rubble or bushes, and covered over with earth; and be derives the term 'thorongh-drainage' from an Essex word 'thorow, meaning a trench to carry off' the water. Crag, a calcareons shelly mixture of phosphates, was extensively used in the eastern part of Suffolk to fertilise the soil. The depth and size of the pits prove the antiquity of the practice. Plonghing was economically conducted: two horses only were nsed; oxen were nnknown : ' no groaning ox is doomed to labour there " is the evidence of Bloomfield. The absence of oxen is an incidental proof of the early enclosure of the county, and of the prevalence of farmers rather than peasant proprietors. Yet, even in these favoured counties, successive corn crops were raised till the land ceased to bear, or weeds overpowered the cereals. Crabbe, himself a native of Suffolk, describes how

Rank weeds, that every care and art defy, Reign o'er the land and rob the blighted rye. 
Little effort was made to restore the fertility of the soil: roots were practically unknown; artificial grasses seldom, if ever, sown: scarcely any manure was used. Under a lease of 1753 a tenant on the manor of Hawsted was allowed two shillings for every load of manure which he brought from Bury and laid upon the land. But during a tenancy of twenty years only one load was charged to the landlord. The impoverished land was left to recover itself as best it could to grass. In the north-west corner of Suffolk tracts of moor and heath, alternating with blowing sands and rabbit-warrens, were interspersed with scanty patches of arable land, choked with weeds, in various stages of exhaustion.

Lord Townshend's estates were situated in Norfolk, then covered with rush-grown marshes, or sandy wastes where a few sheep starved, and 'two rabbits struggled for every blade of grass.' The brief but exhaustive list of its productions is 'nettles and warrens.' Six hundred thousand acres of Lincolnshire were either fen or wold. From Sleaford to Brigg, ' all that the devil o'erlooks from Lincoln town 'was a desolate moor over which a land lighthouse, Dunstan pillar, guided travellers. There were no fences for miles, but the furze-capped sand-banks which enclosed the warrens. The ligh ground running from Spilsby to Caistor was similarly a bleak unproductive heath. From the edge of the wolds to the sea was a boggy wilderness. Both counties were as much additions to the profitable dominions of England as any warlike conquests. Young, in 1760, describes the effect of Townshend's Norfolk husbandry on a district near Norwich :-

- Thirty years ago it was an extensive heath without either tree or shrub, only a sheep-walk to another farm. Such a number of carriages crossed it, that they would 
sometimes be a mile abreast of each other in pursuit of the best track. Now there is an excellent turnpike road, enclosed on each side with a good quickset hedge, and the whole laid ont in enclosures and cultirated in the Norfolk system in superior style. The whole is let at 1כ̌s. an acre, ten times the original value.'

It was not till the close of the century that this description of the improvements effected by the Norfolk system applied to the whole of the county. Still later was it before the methods which turned Lincoln heath from a rabbit-warren to a sheep market were generally adopted in Lincolnshire.

Among the improvements adopted by Townshend was the practice of marling. In ancient leases in Normandy tenants covenanted to marl. In England the practice had died out, owing, as Fitzherbert thought, partly to "ydlenes, partly to want of confidence between landlord and tenant. Markham says that marl was once largely used, since trees 200 or 300 years old grew in spent marl-pits, but that it had been discontinued after the wars of the Roses. Most of the agricultural writers of the serenteenth century, such as Hartlib, Honghton, Worlidge, Plot, agree with Markham in mrging the revival of the practice. Farmers believed that marl was ' good for the father, bad for the son,' till Townshend proved its value on the light sands of Norfolk. The tide of fashion set once more in its farour, and farmers found another proverb for their purpose :-

He who marls sand

May buy the land;

He that marls moss

Sufters no loss;

He that marks clay

Throws all away.

By means of marl alone, Young calculated that 'three or' 
four hundred thousand acres of waste were turned into gar'dens.'

But Townshend's greatest achievement was the field. cultivation of turuips and clover. A new vein of agricultural wealth was struck; turnips became the most active agents as well as the surest indicator's of good farming. Clover and turnips had hitherto been grown as experiments. Tull brought the cultivation of roots to comparative perfection. 'I introduced turnips into the field,' he says, 'in King William's reign ; but the practice did not travel beyond the hedges of my estate till after the peace of Utrecht." A similar prejudice existed against clover. 'Farmers,' as 'Tull states, 'if advised to sow it, would certainly reply, Gentlemen might sow it if they pleased, but they [farmers] must take care to pay their rent.' Townshend was the first great landlord who proved the value of green crops as the pivots of agricultural improrement. He initiated the Norfolk șstem, the merit of which depends on the judicious alternation of roots and grasses with cereals. The introduction of green crops encouraged the farmer to observe what, in the absence of chemical manures, was the golden rule of never taking two corn crops in succession; saved him from leaving a portion of his land every year unproductive; enabled him to increase his live stock and maintain it without falling off during the winter. For the sands of Norfolk, turnips possessed peculiar valne. Roots, fed off on the ground by sheep, fertilised and consolidated the poorest soil. Another portion of the crop, drawn off and stored for winter keep, enabled the farmer to carry more stock, supplied him with more manure, enriched the land, and trebled its yield. It thus became a proverb that ' a full bullock yard and a full fold yard makes a full granary.' Farming in a circle, un- 
like logic, proved a most productive process. Townshend adopted Tull's plan of drilling and horse-hoeing turnips instead of sowing them broadcast. He was an exponent of the maxim that 'the more the irons are among the turnips till the leaves spread across the rows, the better.' His advocacy of turnips earned him the nickname of Turnip Townshend, and supplied an example for Pope's Horatian illustrations-

Why, of two brothers rich and restless, one

Ploughs, burns, manures, and toils from sun to sun ;

The other slights, for women, sports, and wines,

All Townshend's turnips and all Grosvenor's mines.

Those who followed Townshend's example realised fortunes. In thirty vears one farm rose in value from $180 l$. a year to $800 l$.; another, rented by a warrener at $18 l$. a year, was let to a farmer at $240 l$. ; a farmer named Mallet made enough off a holding of 1,500 acres to buy an estate of the annual value of $1,800 l$. a year. Some farmers were said to be worth ten thousand pounds. But the practice spread by very slow degrees. Many persons classed turnips with rats among Hanoverian novelties, and refuser their assistance with Jacobite indignation. Nor was it possible to introduce roots or grasses among open field farmers on land which was common from August to Candlemas. But as the immense benefits of green crops became more evident the work of enclosure was accelerated. Besides the land enclosed by Acts of Parliament, thousands of acres were enclosed piecemeal by interchange among individual occupiers, or by agreement and redistribution in separate parcels among the whole body of commoners. 


\section{CHAPTER V.}

AGRICULTURAL PROGRESS IN THE EIGHTEENTH CENTURY : BAKEWELL AND THE GRAZIER'S ART.

Thr discoreries in the art of stock-breeding made by Bakewell, of Dishley, near Loughborough, in Leicestershire, produced even more startling results than Tornshend's Norfolk system. Before his day the English farmer, like the Lord Chancellor, took his seat on the woolsack. British wool commanded the highest prices at home and in foreign markets; it had been the chief object of agriculturists for three centuries. The classification of sheep as long-woolled, short-woolled, and intermediate, shows that sheep as wool-producing animals had long been studied in Fngland; the fleece, and not the carcass, was valued. Small animals, like the white-faced, hornless Ryeland sheep, were most profitable to farmers. In the reign of Henry VIII. 'Leemynster' wool fetched the highest, Cotswold the second price. Elynour Rummin, alewife of Leatherhead, receired payment in kind for her customers, of whom

Some fill their pot full

Of good Lemster wool.

In 178:3 Ryeland wool was sold at 2s. a pound, when ordinary wool fetched only $4 d$. Owing to the value of the fleece, Ryeland sheep were cotted in Herefordshire 
both summer and winter. Camden describes the cots in Gloncestershire as long, low-ceilinged buildings, three stories high, with slopes at the end of each floor, so that the sheep could mount to the topmost story. He characteristically derives the Cotswolds from this practice of cotting. But in the eighteenth century our farmers gained. a start over other agriculturists by their readiness to detect and accept coming changes. When Lonis XVI. was forming his flock of merinos at Rambonillet to improre French fleeces, English sheep-farming took a fresh departure, which had for its object, not wool, but butcher's meat.

Bakewell was an agricultural opportunist, 'un homme de génie qui a fait autant pour la richesse de son pays que ses contemporains Arkwright et Watt.' He was born in 1725 , and died in 1794. He saw that the day was near when meat would be more valued in the ox than draught, or in the sheep than wool. He succeeded in producing beef and mutton for the million. Visitors gathered from every part of the world to learn from him what are now axioms of stock husbandry, and to see his famous black cart stallion, his bull 'Twopenny,' or his ram 'Two-pounder.' In appearance he resembled the typical yeoman who figures on Staffordshire pottery, 'a tall, broad-shouldered, stout man of brown-red complexion, clad in a loose brown coat and scarlet waistcoat, leather breeches, and top-boots.' In his kitchen he entertained 'Russian princes, French and German royal dukes, British peers, and sightseers of every degree.' He never altered the routine of his daily life. 'Breakfast at eight; dinner' at one; supper at nine; bed at eleven o'clock: at half-past ten, let who would be there, he knocked out his last pipe.'

Before his day no true standard of shape was recog- 
nised. 'Cattle,' wrote Culley in 1809, 'were more like ill-made black hor'ses than an ox or a cow ; nothing would please but elephants and giants.' The favourite type were the gaunt Holderness breed, because they offered most space for the laying on of flesh. Oxen were prized for their power of draught; parish bulls were selected for those qualities which in Obadiah's pet were alleged to be wanting. No attention, except, as Hartlib allowed, in Lancashire and the northern counties, was paid to breed: it was a promiscuous union of nobody's son with everybody's daughter. Thus misshapen wall-sided beasts were scattered all over the country, and prizes were offered for the animal with the longest legs. Similarly sheep were tall, unthrifty beasts, valued for points which were absurd because they were useless. Wiltshire breeders demanded a horn which fell back so as to form a semicircle, in front of which the ear projected; Norfolk flockmasters valued the length and spiral form of the horn and the blackness of the face and legs; Dorsetshire breeders staked everything on the horn projecting forward, so that the ear was behind. Rams were, in fact, selected for horns, legs, and faces. Each county had its breed, unknown beyond its borders. Ryelands were limited to Herefordshire, old Norfolks to Norfolk, Southdowns to Sussex. The only exceptions were Welsh sheep, which were driven up to London for their mutton, and Hampshire downs, which seem to have been known in the seventeenth century as Hertfords. Bakewell's predecessor in sheep-farming was .J. Allom, a breeder of local fame. His own experiments were made on the 'old Leicestershire' or Warwickshire sheep crossed with the Ryeland. Marshall thus describes the 'true old Warwickshire' ram :- His frame large and loose; his bones heavy; his 
legs long and thick; his chine as well as his rump as sharp as a hatchet; his skin rattling on his ribs like a skeleton bound in parchment.'

With these unpromising materials Bakewell in 1750 began his uphill task. He discovered the principle of selection. He only used those rams and ewes that possessed the qualities which he wished to reproduce. As these qualities were perpetuated the breed was formed. His object was to breed animals which weighed most in the best joints, and quickest repaid the food they consumed. 'Small in size and great in value,' or the Holkham toast of 'symmetry well covered,' was his motto. He saw that the value of the sheep lay not in the length of the legs, but the size of the barrel; that the bones must be fine and the form compact, and that the true shape for profit was that of 'a firkin on as short legs as possible.' The great merits of his new Leicester sheep were their fattening propensities and early maturity. While other breeds required three or four years to fit them for market, the new Leicesters were prepared in two. Those who tried the Dishley sheep found that they throve where others starved, that while alive they were the hardiest, when dead the heaviest. Bakewell rapidly made a fortune. In 1755 he let his rams for the season at $16 \mathrm{~s}$. each; in 1789 a society was formed to extend his breed of sheep, which hired his rams at 6,000 guineas for the season.

Bakewell raised the new Leicesters to the highest pitch of perfection. But this was not all. His breed was best suited to the plains, but was ill adapted to hills or mountains. He had, however, shown the way in which breeds might be improved; imitation was easy. In a less immediate sense he was the creator, not only of the new 
Leicesters, but of the Southdowns and the Cheviots. Following in his footsteps, Ellman of Glynde took up the Sussex sheep, and under his skilful care and that of Jonas Webb, of Babraham, the Southdowns competed for supremacy with the new Leicesters. Similarly the Cheviots were improved on Bakewell's principles. Before these breeds, fitted for the plain, the hill, and the mountain, native races, like the Northumberland 'mugs,' the foresters of Nottingham, the Morfe-common sheep, died awar. like Red Indians before more civilised races. But gradually supporters rallied round other varieties. Bakewell's weapons were turned against himself: native sheep of other districts were improved by crossing with the Leicesters or the Southdowns; and though to these two breeds precedence will always be given on historical grounds, it may be questioned whether they have not been rivalled both in beauty and utility.

In cattle-breeding Bakewell was less successful. It was his material, not his system, which failed. He endeavoured to found his typical race on the Westmoreland cattle, the purest breed of the Craven Longhorus. He based his improvements upon the labours of two of his predecessors. Sir Thomas Gresley, of Drakelow House, near Burton, had in 1720 begun the formation of a herd of Longhorns. Webster, of Canley, commenced with some of the Drakelow blood; and Bakewell founded his experiments on two Canley heifers and a Westmoreland bull. But Bakewell could not produce the same results which he had developed in the new Leicester sheep. His cattle were good milkers, and little more. But it was by his example and practice that other breeds, with better natural qualities, were improved. Thus the Teeswater or Durham Shorthorns, both as dairy and meat-producing 
cattle, jumped into the foremost place. Charles Colling's Ketton herd was to cattle-breeders what Bakewell's new Leicesters were to sheep-farmers. In 1810 his stock was sold at an average price of 175 guineas. Similarly Tomkins, in 1769, took up and improved the Hereford cattle, from his two famous cows 'Pigeon' and 'Mottle.' By a pardonable anachronism Scott has assigned to the Laird of Killancureit 'a bull of matchless merit brought from the county of Devon (the Damnonia of the Romans, if we may trust Robert of Gloucester).' But the Devon cattle were only known as draught oxen for the plough in the days of Waverley. Mr. Coke of Holkham brought them into fashion early in this century, and their great breeder was $\mathrm{Mr}$. Quartley.

Bakewell's success and the increasing demand for butchers' meat raised up a host of imitators. Breeders everywhere followed his example : his standard of excellence was gradually recognised. The foundation of the Smithfield Club in 1793 did much to promote the improvement of live stock. In 1710 the average size of the cattle and sheep sold in Smithfield Market was-beeves $370 \mathrm{lbs}$., calves 50 lbs., sheep 28 lbs., lambs 18 lbs.; in 1795 they weighed respectively 800 lbs., 148 lbs., $80 \mathrm{lbs}$., and $50 \mathrm{lbs}$. Part of this improvement must be attributed to Bakewell and his successors, part to the enclosure of the commons. So long as these existed the cattle were stunted, if not starved; and the stint, even if any limit was imposed, was disproportionately large. But local prejudices were hard to overcome; it was years before farmers ceased to value the shape and proportions which gratified the taste of their ancestors. It requires many blows to drive a nail through hearts of oak; or, as others might put it, the 'John Trot geniuses' of farming were hardly convinced 
even by interviews with the Shorthorns or new Leicesters which were paraded through the county. The formation of herds became a favourite pursuit of the wealtly. Flora MacIvor might herself have lived to see the day when country gentlemen were breeders of cattle without being 'boorish two-legged steers like Killancureit.'

Bakewell was a man whose energy and skill deserved success. He was unpopular in his day because of his secrecy; he had no confidant except an old shepherd. So lavish was his hospitality that before the end of his life he had to give up his farm, and died in comparative poverty. His irrigated water meadows, producing four crops a season, his miniature canal, by which the produce of the farm was conveyed to and fro, as well as his skill in stockbreeding, prove him to have been a man far in advance of his age as a scientific and practical farmer. 


\section{CHAPTER VI.}

AGRICULTURAL PROGRESS IN THE EIGHTEENTH CENTURY : ARTHUR YOUNG AND THE DIFFUSION OF KNOWLEDGE.

BEFore 1780 the Eastern counties and Leicestershire had alone profited to any substantial degree by improvements in agriculture or stock-breeding. The character of the farmers, the size of their holdings, the small number of open fields, the terms of land-letting, will explain the keenness of their spirit of progress. Young and Marshall agree that, in these counties, farms were large, and landlords and tenants enterprising. The farmers in Norfolk occupied 'the same position in society as the clergy and smaller squires;' in Lincolnshire ' many had mounted their nags and examined other parts of the country;' in Leicestershire they 'had travelled much and mixed constantly with one another.' Throughout these districts farmers were well edncated, and possessed sufficient capital and confidence, though generally only holding at will or from year to year, to expend large sums of money on their land. In all the other counties agriculture languished, owing to the prevalence of wastes, the absence of leases, the ignorance of the people, the difficulties of communication, the obstinacy of traditionary practices.

The ancient forest of Sherwood, which recalled the days of Robin Hood and Little John, still occupied the 
greater part of Nottinghamshire; Rossendale, in Lancashire, was still a chace; nearly the whole of Derbyshire was a black region of ling; the land lighthouse of Dunstan pillar still guided the traveller from Sleaford to Brigg; Cambridgeshire and Huntingdonshire still defied the assaults of drainage; Northumberland was still overspread with forests of broom, in which a Scotch army might hide; from the northern point of Derbyshire to the extremity of Northumberland a line might be drawn for 150 miles as the crow flies, which passed across nothing but wastes. It was across this district that Jeanie Deans travelled in the reign of George II. Three quarters of Westmoreland, according to Bishop Watson, lay uncultivated. Hounslow Heath and Finchley Common were described in 1793 as wastes, fitted only for Cherokees and sarages. That part of the East Riding called the Carrs, from Bridlington Quay to Spurn Point, and inland as far as Driffield, was an extensive swamp, which produced little but the ague; willow trees marked out the road from Hull to Beverley, and the bells rang at dusk from the tower of Barton-upon-Humber to guide the travellers. Though many farmers in the north were masters of from 5,000 to 40,000 sheep, and tenants of farms from $500 l$. to $2,000 l$. a year, they still milked their ewes, and were ignorant of the nature of a fold.

Half England was cultivated in very small farms, or by small peasant proprietors, or on the common field system. So late as 1794 it is calculated that, of 8,500 parishes, 4,500 were even then still farmed in common. Out of 84,000 acres of arable land in Bedfordshire, 24,000 acres were in open fields. In the 147,000 arable acres of Cambridgeshire, 132,000 were tilled in common; out of 438,000 acres in Berkshire, 220,000 were similarly culti- 
vated. In Bucks 90,000, in Lincolnshire 268,000, in Huntingdon 130,000 acres were under this open field system. The Vale of Pickering, in Yorkshire, was farmed by the township, the common sheep-walks and pastures were overrun with bushes and weeds, the arable fields incessantly ploughed for an mnvarying succession of crops, the meadows mown year after year without intermission or amelioration. At Naseby a few pasture enclosures surrounded the mud-built village; the open fields, tilled on the trinity system, were crossed and recrossed by paths to the different holdings, uneven, filled with cavernous depths of mire: the common pastures were in a state of nature. rough, full of furze, rushes, and fern. Bosworth Field, in 1785 , was in wheat, as it had been three centuries before. In Oxfordshire and the neighbouring counties the common field system extensively prevailed. At Aston Boges, in Oxfordshire, the customs of the manor, ' used time out of mind,' were confirmed in 'ye 35th yeare of Queen Elizabeth, ano. dom. 1593.' The rules of cultivation which they laid down were carried out in the present century by the Sixteens, representatives chosen one from every four of the sixty-four yardlands ${ }^{1}$ into which the manor was divided. In 1797 Rothwell, in Northamptonshire, contained 3,000 acres: 600 acres were small enclosures near the village; the remaining 2,400 acres were in three distinct fields of 800 acres each, partly arable, partly meadow, divided into eighty yardlands cut up into parcels, and scattered over the fields. Stewkley, in Buckinghamshire, was at the same time surrounded by three extended fields, one fallow, one wheat, one beans. There were 104 jardlands of thirty acres each. The main roads were rendered invisible by the driftways to the various properties. The Cotswolds,

1 A yardland generally consisted of 30 acres. 


\section{ARTHUR YOUNG AND THE DIFFUSION OF KNOWLEDGE}

from Broadway to Tetbury, and from Birdlip to Burford, lay unenclosed. Farmers were poor, ignorant, spiritless: holdings were small, wages low. On common fields it was impossible to introduce green crops, or to profit by the discoveries of Bakewell. Young had some reason for the conclusion that the "Goths and Vandals of open field farmers must die out before any complete change takes place.'

In Essex and Suffolk leases for terms of years, with clauses as to management, were not unknown. But even landlords entertained prejudices against leases, because of the supposed want of reciprocity. In 1810 Young found many Oxfordshire landlords who never gave leases, because 'they told the farmer when he might begin systematically to exhaust the land.' Agreements, voidable on either side at six months' notice, were the rule in the country. Where a good nnderstanding existed between landlord and tenant leases were not indispensable. But if tenants at will lost confidence, as in Yorkshire at the close of the century, ' good farming' ceased, for fear the fields should look green, and the rent be raised.' Enterprise was impossible without certainty of return for ontlay. Tenants at will adopted the routine of the district, and plodded along in the beaten track trodden by their ancestors. The Berkshire saying -

He that havocs may sit,

He that improves inust flit,

expressed the popular belief that, if the tenant improved his land, he would be forced either to leave his holding or pay a higher rent. Leases for lives were the usual form, when the tenure was not at will or from year to year. But their utility was marred by the absence of any clauses of management or provision for the maintenance of buildings. In Devonshire leases were, as Fitzherbert advises, for three 
lives; but the landlord was often obliged, as the third life drew to its close, to put himself in as sub-tenant to save his farm buildings from irreparable ruin.

Still greater obstacles to agricultural progress were presented by an inert mass of local prejudice and an obstinate adherence to antiquated methods. The open field system provided sufficient for the occupiers who required nothing more. Where land was enclosed, the ignorance of the farmers made the dissemination of new ideas difficult. Not only could few read or write, but they entertained a not unjustifiable contempt for book-farmer's. Few agricultural writers had had the practical experience of Fitzherbert; most wrote as if they had never travelled beyond the sound of Bow bells. Sometimes their books were too systematic or too general; sometimes their promises were so extravagant as to give literary agriculturists the reputation of quack medicine vendors. Ridiculous and valuable suggestions are intermixed. Here is the remedy, suggested by Hartlib or his editor Beati, for flukes in sheep: "Take serpents or (which is best) viper's; cut their heads and tayles off and dry the rest to powder; mingle this powder with salt, and give a few grains of it so mingled to sheep.' Bewildered agriculturists fared ill between the bad scholarship, the inexperience, and the incorrect chemistry which was offered them in the name of science. In practice experimental farmers had often failed. Like ancient alchemists, they starved in the midst of their golden dreams. Tusser, teaching thrift, never throve. Gabriel Plattes, the cornseller who boasted that he could raise thirty bushels of wheat to the acre, died in the streets for want of bread. Jethro Tull, instead of gaining an estate, lost two by his horse-hoeing husbandry. Arthur Young failed twice in farm management before he began his invaluable tours. 
Difficulties of communication impeded agricultural progress. Under the open field system the neighbourhood had no interest for the village; drift lanes to closes were alone important. Like ancient geographers, they knew their own district, while to all beyond they applied the description of impassable wastes or horrid sands. Some of the great highways were in good repair. Turnpike roads had been established in 1663; and in the reign of George II.

No cit nor clown

Can gratis see the country or the town.

Yet, in the eighteen miles of turnpike road between Preston and Wigan, Young 'measured ruts four feet in depth and floating in mud only from a wet summer,' and passed three broken-down carts. Essex in the time of Fitzherbert was famous for its bad roads. In the eighteenth century it worthily maintained its reputation. 'A mouse could barely pass a carriage in its narrow lanes,' which were filled with bottomless ruts, and often choked by a string of chalk wagons buried so deep in the mire that they could only be extricated by thirty or forty horses. 'Of all the cursed roads that ever disgraced this kingdom in the very age of barbarism none ever equalled that from Billericay to the "King's Head" at Tilbury, was the suffering cry of Young in 1769. The roads of Herefordshire, says Marshall a quarter of a century later, were such as jou might expect to find in the marshes of Holland or the mountains of Switzerland. Norfolk possessed such natural capacity for good roads, that Charles II. suggested it should be cut up to provide highways for the rest of the kingdom. Tet even in this county Young found 'not a yard of good road.' In re- 
moter or more backward parts of England roads were impassable except for well-mounted horsemen, or wagons drawn by trelve horses. In narrow country lanes bells on the team were not an ormament, but a necessary warning. Roads were engineered on the principle that 'one good turn deserves another.' Farmers of one district knew the practices of the next as little as those of Kamtschatka. Outside their limited range were only

Anthropophagi, and men whose heads Do grow beneath their shoulders.

This extreme isolation was a formidable obstacle. Yet the days when Gloncester seemed in 'the Orcades,' and York was a Pindaric flight from London, had advantages. In 1800 it took fifty-four hours for ' $a$ ' philosopher, six shirts, his genius, and his hat upon it,' to reach London from Dublin.

Traditional practices rere agricultural heirlooms, which farmers guarded with jealous care: ocular proof of the superiority of new systems failed to wean them from the routine of their ancestors. Hartlib complained that in Kent he had seen 'four, six, yea, twelve horses and oxen to one plongh;' nor were the teams diminished a century later. By immemorial custom in Gloncestershire, two men and a boy, with a team of six horses, were employed for ploughing. Mr. Coke sent a Norfolk ploughman into the county, who, with a pair of horses and a Norfolk plough, did the same amount of work in the same time. But though the annual expenses were thus diminished by $120 l$. it was twenty years before neighbours profited by the lesson. In 1780 a Norfolk farmer settled in Devonshire, where he cultivated turnips on the newest methods. His crops were larger and finer than those of other farmers; 
yet at the close of the century none had followed his example. Young, in 1768, says that clover and turnips were unknown in many parts of the country. Clorer was not sown in Northumberland before 1752 , turnips did not appear till eight years later. The first root crop in Cumberland was grown in 1755 by Mr. Howard of Corby. Even where turnips were cultivated, drill husbandry was unheard of; broadcast sowing still prevailed; hoeing was hardly practised ont of the eastern comties. As to Jethro Tull, Young adds, 'farmers knew not that such a man existed.' In Devonshire, till nearly the end of the century, the spade was of the shape known to card-players, and crops were carried, or ' 'led,' from the fields, packed in crooks arranged on the backs of horses. Then Davies wrote his report on Wiltshire in 1811, turnips were almost unknown, though sheep were the sheet-anchor of the agriculture of the county. In 1812 Strickland survejed the East Riding of Yorkshire. In that year wheat had reached 122s. the quarter; but much of the land was still in open fields. Irish farmers at the end of the eighteenth century still used sledges, still sowed their potatoes broadcast, still 'walked backwards before their teams, striking them in the face when they wished them to advance,' still 'drew their ploughs and harrows by their horses' tails.' 'Indignant reader,' exclaimed Toung, 'this is no jest of mine, but cruel, stubborn, barbarous truth.' Yet in 16:34 an Act was necessary in England 'agaynst plowynge by the taile.'

The useful work of studying the agricultural practices of England and disseminating the results of scientific experiments was undertaken by Arthur Young. His name is ignored in many works on agriculture, notably in the article in the new edition of the 'Encyclopædia Britannica.' France has better appreciated his merits. In the phrase of 
M. Lesage, his latest translator and editor, she has made an adopted child of his work. Young was born in September 1741, at Bradfield Hall, near Bury St. Edmunds. His father was a Prebendary of Canterbury. From Lavenham School he passed, at the age of seventeen, into a wine merchant's office at Lynn. On the death of his father, in 1763 , he returned home as his mother's bailiff; but his experiments proved so unsuccessful that he was remored from the management of the estate. From various causes he failed twice in farming on his own account before he devoted himself to those tours, in the course of which he has drawn his spirited sketches of England, Ireland, and France. He first visited France in 1787 , on the invitation of the Duc de la Rochefoncauld-Lianconrt, whose tro sons had been partly educated in his neighbourhood at Bury St. Edmunds. Young was a man of keen observation and considerable culture, familiar not only with the writings of English agricultural writers, but with those of De Seres, De Châteauvieux, and Du Hamel. He possessed great talents for description, but little power of generalisation. His arguments in farour of corn bounties, and his depreciation of science, prove him to have shared the prejudices of the day. Tet he was one of the most enlightened and useful pioneers of agricultural improvement that the century produced. His enthusiasm is alwass genuine if it is sometimes extravagant, as when he praises the plumpness of Rubens's female portraits with the eye of a grazier, or remarks of a fine Correggio, 'A fine picture is a good thing, but I had rather it had been a fine tup.' In 1793 he was appointed secretary to the new Board of Agriculture. He died in London in February 1820, having been for ten years totally blind. 


\section{CHAPTER VII.}

AGRICULTURAL PROGRESS IN THE EIGHTEENTH CENTURYTHE SECOND AGRICULTURAL CRISIS-ENCLOSURES OF OPEN FIELDS AND COMMONS FROM 1770 TO 1820.

THE second agricultural crisis was due to the reaction from pasture to tillage in the latter half of the eighteenth and the beginning of the nineteenth centuries. England returned from sheep to arable farming under new conditions and changed circumstances, which rendered it a matter of national necessity to break up open fields, consolidate small holdings, and enclose wastes and commons. Withont large farms, capital, and increased production, it would have been impossible for England to feed her growing population, or to attain her commercial prosperity.

The blow fell in the first instance on the agrarian associations which still farmed the common fields. When Young commenced his tours few counties had changed their external features or agricultural practices for centuries. Hitherto the slow increase of a rural population had been the sole incentive to improvement. Watt, Arkwright, and others changed the condition of society with the suddenness of a revolution. Population was advancing by leaps and bounds; a market was opened for agricultural produce. The farmer lay down at night confident that he could supply his family with food; he woke in the morning to hear the clamour of crowded manufacturing cities 
for bread and meat. Self-sufficing agriculture was an anachronism. How was the new condition to be met? Arthur Young' was ready with his answer. 'Large farms and large capital' was his interpretation of the problem set by the manufacturer to the agriculturist. He proclaimed a crusade against open fields. As a practical farmer, the sight of good land rielding poor crops gave him pain; but he had better grounds for his hostility. Here and there the villagers had appointed field-reeves to direct agricultural operations; but, speaking generally, the farming of the old agrarian communities had deteriorated since the sixteenth century. They could make no use of improred methods of cultivation, rotations of crops, or machinery. Enterprising men were hampered by the apathy of less active partners. If one farmer drained his land, the others stopped up the main drain so that his land was swamped. The strips were too narrow to admit of cross-harrowing or cross-ploughing. No winter crops could be grown because common rights of pasture were enjoyed over the arable fields. Half the day was wasted in going to and fro between the different parcels; the expense of reaping or carting was enormously increased when crops lay in little, remote, and distant strips. Innumerable footpaths to the various closes cut up and contracted the available land. Litigation was perpetual, since selfinterested farmers ploughed up the common balks or headlands, moved their neighbours' landmarks, and filched their land or crops. As 'Tusser said two centuries before of common field farmers, -

Some champions agree

As wasp doth with bee.

The manure of the live stock was wasted on the commons 
instead of enriching the land of incividual owners. Without a general agreement among a large body of small, suspicious, and ignorant independent proprietors, alternate husbandry conld not be adopted by the open-field farmer; tumips and clover, the philosopher's stones which turned sand into gold, were beyond his reach. Where no interest was individual. no private person would improve, drain, or reclaim wastes; no would-be follower of Bakewell conld pursue the science of stock-breeding. The pastures on which the live stock of the township fed generated the rot; promiscuous herding propagated infections disorders. On every common were crowded together half-starved horses, cattle, and sheep, a disgrace to their respective breeds, a fruitful canse of disease, becanse no individual farmer could improve his breed of live stock. Not only was the arable land badly tilled, but the wastes and commons were a standing reproach, from a productive point of view, to the rural economy of the country. It is not surprising that Young should have demanded a general system of enclosure.

His crusade against the old common-field srstem was assisted by other causes. It required little to turn a peasant proprietor into a wage-earning labourer. Every step in the industrial development of the nation tended to the consolidation of farms, the extinction of the commonfield system, and the disappearance of small owners. Commerce drew the peasantry to centres of trade. Eren in the reign of Charles II. petitions were presented against the denudation of country districts and the consequent scarcity of agricultural labour. Thousands of the rural population were attracted from agriculture to manufacture; the small farmer no longer had the aid of his family in the cultivation of the soil, and he could not afford to pay wages. 
Formerly he had no need for money; home production satisfied his domestic wants: exchange or mutual accommodation supplied whatever he conld not fashion for himself. Wealth only existed in its simplest forms; natural divisions of emplorment were not made, because only the rudest implements of production were used. The rapid development of manufacture caused its complete separation from agriculture; the application of machinery to manual industries completed the revolution in social arrangements; a division of labour became an economic necessity. The farmer and the artisan became mutually dependent; barter no longer sufficed, but money was absolutely necessary. Hitherto the rude implements required for the cultivation of the soil, or the household utensils needed for the comfort of daily life, had been made at home. The farmer, his sons, and his servants, in the long winter evenings carved the wooden spoons, the platters, and the beechen bowls; plaited wicker baskets; fitted handles to the tools; cut willow teeth for rakes and harrows, and hardened them in the fire; fashioned ox-yokes and forks; twisted willows into the traces and other harness gear. Travelling carpenter's visited farmhouses at rare intervals to perform those parts of work which needed their professional skill. The women plaited the straw for the neck-collars, stitched and stuffed sheepskin bags for the cart saddle, wove the straw or hempen stirups and halters, peeled the rushes for and made the candles. The spinning-wheel, the distaff, and the needle were never idle; coarse home-made cloth and linen supplied all wants; every farmhouse had its brass brewing kettle. 'The very names of spinster, brewster, baxter, webster, showed that the women spun, brewed, baked, and wove for the household. All the domestic industries by which cultivators of the soil increased their 
incomes, or escaped the necessity of selling their produce, were now supplanted by manufactures. Basket or brush making, pillow lace, straw plait for hats, hand-loom weaving, spinning silk, hemp, or wool, stitching gloves for the trade of Hereford or Leominster, the woollen or worsted manufacturers of Norfolk and Suffolk, the broadcloth trade of Gloncestershire and Wiltshire, the iron manufacturers of Kent and Sussex, the baizes of Colchester and Sturminster, were gradually centred in the cities of the north, instead of being disseminated through the villages of the south. A change of fashion, like the decay of the taste for Derbyshire 'ribs,' brought Brandreth to the gallows. The cheapness of manufactured goods encouraged the dependence of the farmer on the manufacturer; the separation of the two incustries was essential for the perfection of both. The gigantic increase of the population, together with the withdrawal of a large part of the labouring classes from agriculture, demanded the utmost derelopment of the resources of the soil. Small farmers and peasant occupiers were picturesque obstacles to improvement, whose removal was necessary and inevitable.

On agricultural grounds the open-field system was indefensible; enclosures indisputably increased both rent and prodnce. The arguments nsed in its support are based on the damage done to the poor, and the depopulation of enclosed parishes. 'A Country Gentleman,' who, in 1772, wrote a pamphlet upon 'The Advantages and Disadvantages of Inclosing Waste Land,' did not exaggerate the profits of enclosure. He says that rich open-field land was often let in its open state at $6 s$. to $7 s$. per acre. Open farms were divided into two, three, or four fields : if three, one field lay fallow, depastured by sheep; the second was wheat or barley; the third, beans, peas, or oats. $\mathrm{He}$ 
drew up the following table of the probable results of enclosure :-

\begin{tabular}{|c|c|c|c|}
\hline Description of Land & Present Rent & $\begin{array}{l}\text { NewRent } \\
\text { to } \\
\text { Landlord }\end{array}$ & $\begin{array}{l}\text { Net Pro- } \\
\text { fits to } \\
\text { Farmer }\end{array}$ \\
\hline 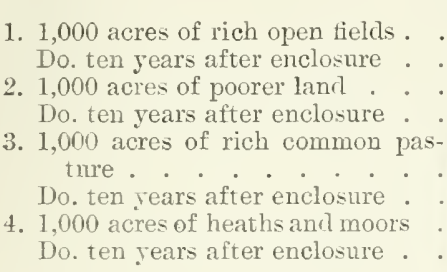 & 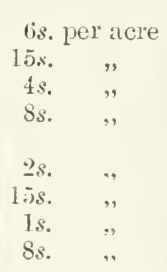 & $\begin{array}{c}E \\
300 \\
750 \\
200 \\
400 \\
\\
100 \\
750 \\
50 \\
400\end{array}$ & $\begin{array}{c} \pm \\
360 \\
500 \\
300 \\
370 \\
\\
240 \\
500 \\
60 \\
370\end{array}$ \\
\hline
\end{tabular}

Within the next half-century these predictions were abundantly confirmed by results; rents and production were more than quadrupled, and farmers grew rich upon war prices.

In 1793 the Board of Agriculture was constituted, with Sir John Sinclair as president, and Arthur Young as secretary. The first object of the Board was to collect information respecting the agriculture of the country. For this purpose a series of questions were circulated among farmers, many of which relater to open common fields. At the same time Commissioners drew up reports of the agricultural conditions of each county. The facts collected in these reports are invaluable to students of agricultural history. They establish beyond all controversy the enormous advantages of enclosed over open-field farms. Tenants lived comfortably on enclosed land, rented at $10 s .6 d$. an acre, who had starved on open farms at 2s. 6d. an acre; enclosed land was cheaper at $20 \%$, than open land at $8 \%$. The effect upon a district near Norwich of enclosures and the Norfolk system has been already illustrated.' 
'The vast benefit,' says Arthur Young, ' of enclosing can, upon inferior soils, be rarely seen in a more advantageous light than upon Lincoln Heath. I found a large range which formerly was covered with heath, gorse, \&c., and yielding, in fact, little or no produce, conrerted, by enclosure, to profitable arable farms; let, on an arerage, at $10 \mathrm{~s}$. an acre; and a very extensive country, all studded with new farmhouses, barns, offices. and every appearance of thriving industry; nor is the extent small, for these heaths extend near serenty miles.' Nor were these exceptional cases; ther might be paralleled in every county in the United Kingdom.

But enclosures aimed at more than the extinction of openfield farms. Wastes and commons were also to be fenced and reclaimed. In 1773 Arthur Young drew attention to the extent of land lying waste in his 'Observations on the Present State of Waste Lands of Great Britain.' The Report of the Committee of the Board of Agriculture upon Enclosures states that twenty-two million acres of land lay waste, of which England had 6,259,470 acres, Wales $1,629,307$ acres, Scotland $1+, 218,221$ acres. To this report is annexed a valuable sketch of the old law of wastes and commons, presented by the Surveyor-General of Woods. and Forests. The surveyor held that the common law annexed rights of common to all manors because of the inducement they afforded cultivators to till their land as arable farms, but that since the introduction of roots and artificial grasses no such need existed. If commons were unlimited, lords of manors might enclose; if stinted, commoners were often owners of the soil. The earliest method of enclosure was by writs of partition or admeasurement. But the proceedings were so costly that they were little 1 Agricultural Surrey of Lincolnshire, 1799, pp. 77-8. 
used. In more modern times commons were divided by consent of the interested parties, ol by private Acts of Parliament. Here, again, formidable obstacles impeded enclosures. It was difficult to obtain the consent of persons whose interests were opposed; but fonr-fifths of the commoners, the lord of the manor, and the tithe-owner must agree before a Parliamentary sanction conld be obtained. Cottagers were attached to the idle system of keeping a few half-starved cows upon the commons; small freeholders feared the legal expense; small common-field farmers dreaded a rise of rent; landlords hesitated to invest capital for the benefit of tithe-owners; tithe-owner's were unwilling to take land in exchange for their tenths of the produce. Finally, the expenses of private Acts were almost prohibitive. A General Enclosure Act was imperatively needed, but if such a measure was passed, 'what,' as a reporter asks. 'would become of the poor but honest attorney, officers of Parliament, and a long train of \&c. \&c., who obtain a decent livelihood from the trifling fees of every individual Enclosure Bill? The waste lands in the dribbling, difficult way in which they are at present enclosed will cost the country upwards of 20 millions to these gentry, which nuder a general Enclosure Bill would be done for less than one million.' Partly from social causes, partly in consequence of the recommendations of the Board of Agriculture, partly through the zeal of Arthur Young, but mainly through the necessity rhich presses upon a protectionist country, enyuged in a European wai, to feed its yrowing populution out of its home resources, the first general Enclosure Act was passed in 1801. From 1777 to 1793 , 599 Enclosure Acts were passed. Between 1793 and 1809 the number rose to 1,052. It has been calculated that $4 \frac{1}{2}$ million acres of land were thus added to the 
cultivated area of the country in England and Wales alone.

The agricultural and economical aspects of the question favoured enclosure, but the social argments were less conclusive. It was, indeed, urged that enclosure of commons would benefit the morality of the country. The commoners are described as a ' most wretched ' class, relying' on a precarious and vagabond subsistence, eked out by pilfering. Their 'miserable huts' are 'seldom or never abodes of honest industry,' but harbour 'poachers and thieves of every description.' Forests, like Epping or Hainault, were the resort of 'the most idle and profligate of men; here the undergraduates in iniquity commence their career' with deer-stealing, and here the more finished and hardened robber retires from justice.' On the other hand, it was said that enclosures depopulated the country, were often needlessly created, and inflicted irreparable damage upon the poor.

The depopulation of the country by enclosures was not confirmed by experience, becanse the object of the change was rather the increase of tillage than, as in the sixteenth century, the extension of pasturage. Arthur Young, in 1801,1 proves by statistics, that of thirty-seven enclosed parishes in Norfolk, population had risen in twenty-four, diminished in eight, and remained stationary in five. In some few instances, no doubt, land was enclosed and ploughed which would have been more profitable as open pasture, but these cases were rare and exceptional. The real strength of the argument against the enclosure of commons lay in the injury they often inflicted upon the poor. 'The 'Country Gentleman,' whose pamphlet has been

\footnotetext{
I Inquiry into the Propriety of applying I'astes to the Better Support and Muintenanee of the Poor.
} 
already quoted, recognises this as an inevitable result. The landlord, the farmer, and the nation must gain by enclosure, but 'the small common-field farmer' must become 'a hired labourer.' He recommends that the lot of these 'reduced farmer's' be rendered as easy as possible ' by laying to their cottages a sufficient portion of land to enable them to keep a cow or two.' Had this advice been followed, England might have escaped the deplorable effects of the poor-law in the next fifty rear's.

The claims of commoners were frequently disregarded by Commissioners. Young strongly adrocated enclosures, but he laments the disastrous effect of the cliange upon the general condition of the labouring population. He instances numerous enclosures which, without adequate compensation, deprived commoners of their live stock, made it difficult or impossible to procure milk for their children at any price, cut off their chief incentive to frugality, reduced them to hired labourers solely dependent upon their reekly wages. 'Many kept cows that have not since;' is his oftrecurring summary of results. Out of thirty-seren parishes he found only twelve in which the position of the poor was improved by the enclosure of commons. ${ }^{1}$ Many commoners received no allotment because they failed to prove their legal right; others were assigned too little land to keep a cow, and both land and cow were sold to wealthy farmers; others were bonght out for comparatively small sums before the award was made; others sold their allotments because they could not spend the sums necessary to enclose their portions; in some cases allotments were made to the owners and not to the occupiers of cottages. On the other hand, in some parishes the interests of the poor were carefully protected; they were not required to give strict proof of their legal

$$
1 \text { Arthur Young, On Wastes, } 1801 .
$$


rights, and were allotted sufficient land for the summer and winter keep of their cows. Wherever this plan was adopted the poor rate remained low, even dnring the troubled times of the French war. Men of that generation, who knew what it was to keep and to want a cow, preferred the cow to parochial relief of $5 \mathrm{~s}$. or $6 \mathrm{~s}$. a week.

Against these indiridual losses must be set the national gain. Without the enclosure of commons England conld never have fed her growing population, or gained the first place in the race for industrial supremacy. 'Where,' asks Arthur Young, ' is the little farmer to be found who will cover his whole farm with marl at the rate of 100 or 150 tons per acre? who will drain all his land at the expense of $2 l$. or $3 l$. an acre? who will pay a heavy price for the manure of towns, and convey it thirty miles by land carriage? who will float his meadows at the expense of $j l$. per acre? who, to improve the breed of his sheep, will give 1,000 guineas for the use of a single ram for a single season? who will send across the kingdom to distant provinces for new implements, and for men to use them? who will employ and pay men for residing in provinces where practices are found which they want to introduce into their farms?' Nor was the commoner without compensation in more certain employment and higher wages. If it is unpractical sentiment to regret the enclosure of commons, the rural poet of Dorsetshire may be invoked to tell the greatness of the loss to the labouring population.

Thomas (loq.) :

Why, 'tis a handy thing

To have a bit o' common, I do know,

To put a little cow upon in spring,

The while woone's bit or orchard grass do grow.

Jonx: Aye, that's the thing, you zee. Now I do mow

My bit o' grass, an mëake a little rick ;

An' in the summer while do grow, 
My cow do rum in common ror to pick

A bläde or two o' grass, if she can vind 'em, Vor tother cattle don't leave much behind 'em. An' then, bezide the cow, why, we do let Our geese run out among the emmet hills; An' then, when we do pluck 'em, we do get Vor sëale zome veäthers an' zome quills ; An' in the winter we do fat 'em well, An' car them to the market ror to zell To gentle-rolks.

An'then when I ha' nothèn else to do, Why, I can teäke my look an' gloves, an' goo To cut a lot o' vuzz and briars Vor hetèn ovens or vor lightèn viers; An' when the childern be too young to eärn A penny, they can g' out in zumy weather, An' run about, an' get together

A bag o' cow-dung vor to burn.

The change came at a difficult crisis. An artisan class was arising, and population shifting from the south to the north. Commoners and open-field farmers could not readily adapt themselves to altered conditions, or join in the keen struggle for existence which was commencing. At the same time the prices of necessaries were doubled during the war; yet wages remained the same. It was this combination of circumstances which rendered the poorlaw system so fatal. And the law was most unwisely administered. The weekly earnings of labourers were supplemented from the poor rate with such a sum as in the opinion of the magistrates would support their family ; a shilling $\mathrm{or}^{2}$ eighteen-pence was paid for each child. This bounty upon production threw single men upon the rates, because employers calculated that labourers with the largest families required least wages. While the war swelled farmer's' profits, ratepayers paid their labour bill. Wages 
were regulated not by services, but by wants. Such a system promoted early marriages, encouraged a superabundant population, increased the number of illegitimate births, amnihilated distinctions between good and bad workmen. It was now that the south fell hopelessly behind the north. As population centred round the coalfields, the manufacturing industries of the south dwindled, and its cloth and iron workers swelled the number of the indigent poor. After the peace of 1815 , disbanded soldiers, sailors, and militia-men added to the number of the discontented and unemployed. Thousands of artisans were discharged as machinery was introduced into manufactures. Thus the balance between the demand and supply of labour was completely orerthrown, and the distress of the wage-earning populations from 1810 to 1820 was only paralleled by the miseries of the sixteenth century. 


\section{CHAPTER VIII.}

LARGE FARMS AND LARGE CAPITALISTS-MR. COKE OF НOLKНАM.

A LARGE expenditure of capital was needed to bring into cultivation the newly reclaimed commons or the barbarously cropped and impoverished open fields. But in order to derive full profit from the outlay it was necessary to obtain access to the new narkets. Agriculture and manufacture agreed in demanding increased facilities of transport and communication. The demand created the supply. Hitherto the charges for the conveyance of heavy goods had been practically prohibitive. Except in the summer, farmers were confined to the nearest markets and deprived of the stimulus of competition. The impassable condition of the roads led to the widest differences in the prices of neighbouring districts. Meat varied with the distance from London; within fifty miles of the capital it was $4 d$., beyond that limit $2 d$; as the distance increased prices fell, and farmers at Horsham were glad to take five farthings a pound for mutton. Food rotted upon the ground in one parish, while in the next there was a scarcity. The cornlaw legislation of the eighteenth century provided for variations of prices in twelve different districts of England and Wales. Between 1760 and 1780 all the main roads were repaired, while Brindley's construction of the Bridgewater Canal established a canal mania, only paralleled by the railway mania of this century. Within a few years 
England was better provided with means of inland navigationt han any country except Holland. At first new means of communication depressed the wage-earning labourer. Wages were generally low where food was cheap ; increased facilities of transport equalised the price of meat, bread, cheese, butter; but wages were slow to follow the rise of prices, and it was fifty year's before the balance was restored.

Increased facilities of communication accelerated the rapid development of manufactures. When once the home markets were thrown open, agriculture received an extraordinary stimulus from the high prices of farm produce, and the increased demand consequent on a growing population and an improved standard of living. Napoleon became the Triptolemus of the farmer. The stoppage of foreign grain supplies, war prices, the corn laws, made land a profitable investment for capital. Even the fall of prices in 1814 only excited agriculturists to renewed efforts. New implements were tried; labour was economised by the inventions of Small and Meikle; cattle shows and plonghing matches were held throughout the country; prizes were offered to local breeders; farmers' clubs and provincial societies were established. Great landlords took the lead in improvements. It is said that Walpole always opened the letters of his farm steward before he broke the seals of letters on State affairs. Bolingbroke caused his house at Dawley to be painted with trophies of ricks, spades, and prongs, and read Swift's letters between two haycocks with his eyes to hearen, not in admiration of the dean, but in fear of rain. The later generation were more earnest or more practical. In 1723 a society of ' Improvers in the Knowledge of Agriculture' had been formed in Scotland; in 1777 the Bath and West of England Society was instituted, the Highland Society in 1784, the Smithfield Club in 1793. In the latter year Pitt, at the instigation 
of Sir John Sinclair, created the Board of Agriculture, with Young as secretary. 'Farmer George' contributed articles mder the signature of Ralph Robinson to Young's 'Annals of Agriculture,' kept his model farm at Windsor, and experimented in stock-breeding. So far Byron's epigram may be accepted -'A better farmer ne'er brnshed dew from lawn.' Lord Rockingham at Wentworth, the Duke of Bedford at Wobum, Lord Egremont at Petworth, and crowds of other landlords, followed the King's example. Fox in the Lonvre was lost in consideration whether the weather was favomrable to his turnips at St. Anne's Hill. Burke was seen by Young experimenting in carrots as a field crop on his farm at Beaconsfield, though he directed his sarcasm against the Duke of Bedford's devotion to agriculture. Lord Althorp, in the present century, worthily maintained the traditions of his official predecessors. During a serions crisis of affairs, when he was Chancellor of the Exchequer, John Grey of Dilston called upon him in Downing Street upon political business. Lord Althorp's first question, eagerly asked, was 'Have you been at Wiseton on your way up? Have you seen the cows?' No new book escaped the vigilance of' agriculturists. Miss Edgeworth's 'Essay on Irish Bulls' had not been published three days when it was ordered by the secretary of the Bath and West of England Society of Agriculture. Nor were the clergy less enthusiastic. An archdeacon, finding the churchyard cultivated for turnips, rebuked the rector with the remark, 'This must not occur again.' 'The reply, 'Oln no, sir, it will be barley next year,' proves that the eighteenth-century clergy were at least zealous for the rotation of crops.

Large farms and large capital found in Mr. Coke of Holkham their most celebrated champion. In 1776 he .came into lis estate, with 'the King of Denmark' as 'his 
nearest neighbour:' The refusal of a tenant in 1778 to accept a lease at an increased rent threw a quantity of land on his hands. Excluded by his politics from court and Parliament, he thenceforward devoted himself to farming. His energy was richly rewarded. Dr. Rigby in 1816 ('Pamphleteer,' xiii. p. 15) stated that the rental of the Holkham estate rose from 2,200l. in 1776 to 20,000l. in 1816.

When Mr. Coke took his farm in hand, not an acre of wheat was to be seen from Holkham to Lynn. The sandy soil grew nothing but rye. No manure was purchased; the little muck that was produced was miserably poor: a few Norfolk sheep and half-starved milch cows were the only live stock. He determined to grow wheat. $\mathrm{He}$ marled the land, purchased large quantities of manure, trebled his live stock. At the end of nine years his object was attained. He saw that on land like that of Norfolk muck was everything. 'The Flemish saying applied equally to the eastern'counties: 'Point de fourrage, point de bestianx; sans bestiaux, ancm engrais ; sans engrais, nulle récolte.' In 1772 the value of bones as manure had been accidentally discovered by a Yorkshire foxhunter, who was cleaning ont his stable. Coke profited largely by the discovery. He also introduced into the country oil-cake and other artificial foods, which, with roots, enabled the Norfolk farms to carry increased stock. Under his advice and example stall-feeding was extensively practised. Cattle and sheep were sent up half fed to the Norfolk fairs, to be bonght by graziers and fattened for the London market. On 'Bullocks' Hill, near Norwich, during the great fair of St. Faith's, were assembled drovers of every county, with Galloway Scots, Lowland Scots, Highlanders, and Skye cattle, besides beasts from less remote districts. The grass lands, on which the beef and mutton of our ancestors 
were raised, were deserted for the sands of the eastern counties; the metropolis drew its meat supplies from Norfolk. The cattle were sent up to Smithfield under the care of drovers, who took a week on the journey. The busiest time of the year was from April to June. The quantity of animals fattened on nutritious food gave the farmer the command of the richest manure, fertilised his land, and enabled him not only to grow wheat, but to verify the maxim, 'never to sow a crop unless there is condition to grow it luxuriantle.'

Coke also improved the live stock of the county. On his own estate, after patient trial of other breeds, he adopted Southdowns and North Devons. But his efforts were not confined to the home farm. Early and late he worked in his smock-frock, assisting his farmers to improve their flocks and herds. Grass lands were wholly neglected till he gave them his attention. If land wanted seeding, farmers threw indiscriminately on the ground a collection of seeds, drawn at haphazard from their own or their neighbours' ricks, containing as much rank weed or rough grass as nutritions herbage. It was a mere chance whether the farmer aided the sour or the sweet grasses in the struggle for existence. Stillingfleet, in 1760, distinguished the good and bad herbage by excellent illustrations of the kinds best calculated to produce the richest hay and sweetest pasture. Coke was the first farmer who appreciated the value of the distinctions. During May and June, when the grasses were in bloom, he gave his botanical lessons to the children of his tenantry, who scoured the country to procure his stock of seed.

Convinced of the community of interests among owner, occupier, and labourer, Coke stimulated the enterprise of his tenants, encouraged them to put more capital 
and more labour into the land, and assisted them to take advantage of every new invention or discovery. His farm buildings, dwelling-houses, and cottages were models to other landlords. By offering long leases of twenty-one years, he guaranteed his tenants a return for their outlay and energy. 'My best bank,' said one of his farmers, 'is my land.' At the same time he guarded against the mischief of a long unrestricted tenancy by regulating the course of cultivation. In all the leases of his estates he inserted covenants for the adoption of the Norfolk system of husbandry. Though clauses of management were then comparatively unknown, his farms commanded the competition of the pick of English farmers. Even Cobbett, in spite of his prejudices against landlords, was compelled to admit the benefits which Coke's tenants derived from his paternal rule. 'Every one,' he wrote in 1821, 'made use of the expressions towards him which affectionate children use towards their parents.'

One great obstacle to improvement remained. Farmers of the eighteenth century lived, thought, farmed, like the farmers of the sixteenth. The Holkham sheepshearings did much to break down traditions and prejudices. These meetings began in 1778, in Mr. Coke's own ignorance of farming matters: he annually invited small parties of farmers to his house to discuss agricultural topics and aid him with their advice. In 1818 open house was kept at Holkham for a week; hundreds of persons assembled from all parts of Great Britain, the Continent, and America. The mornings were spent in inspecting the farms and the stock; at three o'clock six hundred persons sat down to dinner; the rest of the day was spent in toasts and speeches. Among the pupils was Erskine, who abandoned the study of Coke at Westminster 
Hall to gather the wisdom of his namesake at Holkham. At the sheep-shearings were collected practical and theoretical agriculturists, farmers of different districts, breeder's of every stock. The Duke of Bedford, Lord Egremont, and other landlords established similar meeting's in different parts of the country.

National necessities demanded the extinction of the open-field farmer, and the enclosure and reclamation of wastes and commons. The same causes during this period brought the same fate upon the small freeholders or yeomen. More substantial than the open-field farmer or the cottager, they maintained their struggle for existence with more tenacity. 'The evidence of the Agricultural Commission of 1833 proves that they still existed in almost every county. But their numbers were already diminished. The social advantages of landownership combined with high profits to give land a fancy value. In Cheshire, during the French war, agricultural land fetched as much as forty years' purchase. Yeomen consulted their pecnniary advantage by selling their estates; capitalists gratified both their tastes and their speculative instincts by buying land. It was manifestly the interest of small freeholders to sell their properties, the size of which prevented their taking full advantage of the price of corn, and to employ their capital in farming hired land. Those who remained on their own estates were for the most part ruined. War prices and the corn laws made farming a gambling speculation; the wheat area alternately contracted and expanded; violent fluctuations in the value of farm produce upset all calculations. Many yeomen mortgaged their estates to make extravagant provision for their children, to buy more land, to enclose and improve their properties, or to erect better farm buildings. 
Prices fell, but the debt remained. The struggle was brief; farming deteriorated, buildings fell into ruins, finally the estate was sold. The purchasers were not yeomen, for after 1820 small capitalists ceased to invest their savings in land, but neighbouring squires or successful manufacturers. In Shropshire their capital dwindled, and they were forced to sell. In Wiltshire their farming retrograded and their buildings fell into bad repair. In Yorkshire the number of small proprietors diminished: formerly, if one small freeholder went, another took his place; now this ceased to be the case. In Worcestershire the small owners were obliged to sell, and men of their own class ceased to buy land after 1812. In Kent and Somersetshire many freeholders retained their land by practising the most rigorous self-denial, and by entirely ceasing to employ labour; but all who had mortgages or amnuities to pay were forced to sell their properties. Everywhere large landed properties were built up on the ruin of small landowners. It was only in counties like Lancashire, where the prices of dairy produce had not fluctuated during the war, and where huge markets sprang up at the doors of the farmer, that yeomen weathered the storm. The agricultural gain, derived from the extinction both of the common-field farmer and the small freeholder, was at the time great and undeniable. 'One-horse farmers' on heavy soils liad to struggle with the inconvenience of borrowing and lending horses. Hours were wasted before the teams conld be collected and baited; the process of ploughing was interrupted by frequent turns in small fields; the area of cnltivation was unduly encroached upon by hedgerows; the methods of farming were antiquated, the implements old-fashioned; without stock, capital, or machinery, living from hand to mouth, 
unable to buy manure, or cake, or any but the poorest sheep and cattle, the small yeoman could not hope to compete with the large tenant farmer. On social grounds the removal of small proprietors was a deplorable necessity. But the alternative was the starvation of millions of artisans. 


\section{CHAPTER IX.}

SCIENCE WITH PRACTICE, 1812 TO 1845.

If the present century has not proved uniformly prosperous to farmers, it has witnessed a miraculous advance in the scientific practice of agriculture. Farming has advanced with gigantic strides. Tast capital has been expended on farm buildings and drainage; new tracts of land have been brought into cultivation. Steam and machinery have lightened the toil, lessened the cost, and increased the amount of production. Systems of cultivation are better adapted to the requirements of soil and climate; more live stock is kept, and it is both better bred and better fed. The farmers' resources of crops, winter food, manures, appliances, are infinitely increased. New means of transport and communication bring markets to the remotest door. But the chief improvement has been the diffusion of intelligence and education; the work inangurated at the Holkham sheep-shearings has gone on apace. The 'rough-shod race' no longer despise science. Bucolic life was the pastime of the town, the relaxation of statesmen, the inspiration of poets; but farmers neither asked nor allowed scientific aid. Now good farming combines scientific knowledge with practical experience. The dawn of the new era was marked in 1812 by Davy's lectures before the Royal Society, and the adoption by that body of the motto 'Science with Practice.' Progress does 
not depend on chance-directed discoveries by unlettered rustics, but on experiments conducted by the rich and learned. History shows that unaided agriculturists have by sheer doggedness conquered most formidable difficulties. Foreign competition is a more insidious foe than the open revolt of nature's 'wayward team;' but the forces arrayed on the side of English agriculture are now indefinitely multiplied. Within the last century capitalists, mechanics, architects, geologists, chemists, phrsiologists, botanists, hare been enlisted on the side of the farmer. The agricultural progress of the present century is, in fact, summed up in the application of science and capital to the cultivation of the soil.

In the years 1812 to 1845 is included one of the most disastrous periods of English farming. It is also the period of Protection." Inflated prices raised rentals and the standard of living, and rastly increased the area under corn cultivation. Prices fell when the war terminated. Contracts of all kinds had been made in the expectation that those prices would continue. Landlords declared that their ruin was ineritable if rents were reduced, and farmers, holding under leases, felt the full pressure of the crisis. These facts came out in the Reports of the Select Committee on the Corn Trade, which sat in 1814, and increased Protection was the result. Farmers had learned that fortunes were to be made by growing corn, and once more expectations and rents rose together. But wheat steadily declined. For a few rears farmers paid their exorbitant rents out of capital ; but the end could not be long deferred. Again Select Committees sat in 1821-2. It was shown that rents had increased not less than 70 1 See Appendix IY., The Corn Laws. 
per cent. on the rentals of 1790. Agriculturists demanded that foreign corn should be prohibited; but the Committee of 1822 hinted that Protection was undesirable, and proposed nothing. Violent fluctuations in prices continued to overthrow all calculations; the wheat area now swelled and now shrivelled, and the sliding scale of 1829 only increased the speculative character of the farmer's trade. Select Committees sat again in 1833 and 1836, and evidence was given that farmers had lost all they had, and were working on the road; in the weald of Kent and Snssex there was scarcely a solvent tenant. The last ten years proved more prosperous; but the improvement was mainly due to better farming, the growth of population, the alteration of the poor laws, and the Tithe Commutation Act of 1836. Such is a brief epitome of the agricultural history of a period which will be examined in more detail.

The advance made in farming between 1812 and 1845 was effected in the face of almost unexampled distress. During the years 1773 and 1793 English imports and exports of grain balanced each other, and these twenty years mark the turning-point when the nation passed from growers into consumers of corn. Within the next two decades of years the war and deficient harvests forced up the price of agricultural produce. While the East drained England of its bullion, Pitt's issue of paper money inflated prices. As bank notes circulated in greater quantities, prices rose higher and higher. Wheat in 1800 and 1801 was driven up to the unprecedented height of $110 \mathrm{~s} .5 \mathrm{~d}$. and $115 \mathrm{~s} .11 \mathrm{~d}$; f for the five years 1809-13 it averaged 103s. 10d. Buyers of land paid forty and forty-five years purchase, raised heavy mortgages on their estates, charged them extravagantly with annuities, and loaded them with 
legacies and portions for younger children. Yet the land seemed to stand the strain. Rents were doubled and cheerfully paid by farmers who made fortunes ont of the war prices. Throughout the war the efforts of legislators were directed to the maintenance of high prices of homegrown grain. Heavy duties were imposed on foreign corn in 1804; they were increased in 1813, again in 1814, and again in 1815. It is, however, noteworthy that the last increase was not passed without a protest from ten peers, entered upon the journals of the House. The same policy was continued from 1815 to 1845 . One argument, strongly urged upon Parliament throughont the whole period of Protection, was that, if prices fell, the land newly brought under the plough must necessarily fall out of cultivation. An extraordinary stimulus was thus given to enclosures; ${ }^{1}$ 601 Acts were passed between 1810 and 1814, and at the same time the wheat-growing area was enormously increased. During this war period money was drawn together in masses in the hands of saving farmers and traders. A significant proof of the growing wealth is afforded by the amount of capital paying legacy duty, which rose from $1,116,680 l$. in 1797 to $33,118,281 l$. in 1820 .

But while all who sold produce profited by the artificial prices of commodities, the wage-earning population sank lower and lower. Agricultural labourers had lost their commons; their wages were supplemented not by their industry, but by their pauperism; and the poor rates exactly doubled between 1801 and 1813 .

At the close of the war distress prevailed over the whole of Europe. Throughout the progress of the struggle England, owing to her insular position, had suffered less

1 See Appendix V., Enclosures. 
than other countries. Its termination found her with a national debt of orer 900,000,000l., an excessive taxation levied to meet the war expenditure, falling prices and dwindling industries, a disordered currency; a fictitious credit, and a mass of unemployed labour. 'Peace and plenty' proved a ghastly mockery. Distress had always succeeded the close of war. In 1764 and again in 1784 farmers suffered severely from the sudden diminution of the demand for their produce. In 1815 the distress was proportionately increased by the length of the struggle and the exertions which the comntry had made. England lost the monopoly of trade which she had enjosed during the war; her manufactures exceeded the demand; warehouses were overloaded, markets overstocked; produce was unsold or unpaid for ; iron furnaces were blown ont, cotton mills closed; the coal trade languished; the shuttles stood still in Lancashire and Yorkshire. Distrust and speculation replaced wholesome and natural commerce. Side by side with commercial depression went agricultural distress. The bitter cry of the landowners was heard in the Honse of Commons, and in 1815 the monopoly of the lome market was secured to British growers mnless wheat was above $80 \mathrm{~s}$. But the sudden fall of prices in 1814 and 1815 , consequent on over-production and the diminished value of the currency, had already spread ruin and bankruptcy among the agricultural classes. In 1816 the Board of Agriculture issued a circular letter inquiring into the general conditions of agriculture. ${ }^{1}$ The answers, to which reference has been already made, reveal the gravity of the crisis. Landlords lost, by reductions alone, 9,000,000l. on their rentals of the preceding years; many farms were thrown up; notices to quit poured in. Large tenants, farning on borrowed capi1 See Appendix VI., Questions of the Board of Agriculture. 
tal, had become parish paupers; bankruptcies, seizures, executions, imprisonments for debt, were universally prevalent. The evidence laid before the Select Committee of 1821 confirms the truth of these reports. In Dorsetshire, for instance, fifty-two farmers, cultivating between them 24,000 acres, failed between 1815 and 1820. Rents were lowered in Somersetshire by a third, and the small farmers were reduced in point of diet to the condition of labourers, and the latter were compelled to subsist on bread and potatoes. In Sussex, again, rents fell, upon an average, 53 per cent. Even on large farms in Norfolk tenants suffered severely, and put down their chaise and riding horse. The blow fell the more heavily on the southern counties, among other reasons because the old practice of lodging and feeding labourers in farmhouses had been discontinued during the war, and money wages could only be paid by unprofitable sales of produce. Rents fell into arrear; tithes and poor rates remained unpaid; improvements were discontinued; live stock dwindled, and gangs of poachers and depredators kept the country in continual alarm. Numerous tradesmen, innkeepers, and shopkeepers, who depended on farmers for their principal custom, were involved in the same ruin. War prices were gone, war taxes remained. Out of falling profits owners of land were unable to meet augmented taxation and heary charges; occupiers could not pay rents which had been raised upon fallacious estimates of agricultural prosperity, and were slowly and reluctantly reduced. Meanwhile the credit of the paper currency was undermined; bank notes were discounted at a loss, and guineas sold at a premium. The failure of numerous county banks, which between 1797 and 1814 had increased in number from about 200 to 940 , added to the ruin of country districts. As the year 1816 ad- 
vanced, bad seasons created a scarcity; wheat rose suddenly from 52s. in January to $103 \mathrm{~s}$. in December; the potato crop, which had recently become important in England, failed; and the perpetual floods of the spring and summer were succeeded by a winter of appalling severity. The army and navy had been reduced, the militia disbanded, the store, commissariat, and transport departments placed upon a peace footing. To this mass of unemployed labour were now added thousands of artisans and agriculturists. Starvation stared them in the face. Distress bred discontent, and discontent disturbances which were fostered by political agitators. While the Luddites broke up machinery, gangs of labourers avenged the fancied conspiracy of farmers by burning stacks, ricks, and farmhouses, or destroying the shops of butchers and bakers.

Peace seemed only to aggravate every form of distress. At such crises the currency is often made the sole scapegoat for conditions which result from many causes. But one great cause of the general depression was the paper money, upon which had been built up extravagant ideas of the national wealth. Till cash payments were resumed financial equilibrium could not be permanently restored. The process by which the paper money was withdrawn extended over the first twenty years after the conclusion of the peace; but its general course was directed by Lord Liverpool's adoption of the single gold standard, and Peel's Currency Bill of 1819, to which the House of Commons agreed without a dissentient voice. The withdrawal of the paper money produced the same result as a drain upon the precious metals. A variety of causes combined with the resumption of cash payments to send down prices with 
startling rapidity. ${ }^{1}$ Landowners, who had raised money upon their land, found themselves confronted by ruin. Their reluctance to reduce rentals involved hundreds of tenants in their fall. The alternative was hard. Petitions show that where mortgagees foreclosed upon estates the land was sold for sums which barely, if at all, recomped the charges. In 1819 Cobbett's ominons prophecy respecting the Currency Bill seemed in danger of literal fulfilment: 'Before this Bill conld be carried into complete execution a million of persons at least must die of hunger.'

The cheapness of food abated distress among the manufacturing population, but it aggravated the difficulties of farmers. For the next fifteen years the attention of Parliament was continually called to the landed interests. Resolutions were passed at county meetings demanding relief; innumerable pamphlets proved that three pounds did not now go as far as two had done during the war, ${ }^{2}$ and asked for remunerating prices for agricultural produce; petitions covered the table of the Honse, and select committees sat in 1820, 1821, 1822, 1833, and 1836. But within twenty years after the peace had been readjusted to diminished prices, and agriculture slowly began to share in

1 Tuble showing the Fall of Prices, 1819-22.

\begin{tabular}{|c|c|c|c|c|c|c|c|c|c|c|c|c|}
\hline \multirow{3}{*}{$\frac{\text { Dates }}{\text { Jan. } 1819 .}$} & & \multicolumn{3}{|c|}{ Wheat per quarter } & \multicolumn{4}{|c|}{ Mutton per stone ( $8 \mathrm{lbs}$.) } & \multicolumn{4}{|c|}{ Beef per stone $(8 \mathrm{lbs}$.) } \\
\hline & & $s$. & & $s$. & s. $d$. & & $s$. & d. & $s$. & d. & & s. $d$. \\
\hline & & 64 & to & 84 & 50 & to & 6 & 4 & 4 & 0 & to & 0 \\
\hline July 1819 . & . & 58 &, & 80 & +6 &, & 5 & 2 & 4 & 6 &, & 4 \\
\hline Jan. 1820 . & . & 54 & , & 70 & 3 & , & 4 & 4 & 3 & 4 & $"$ & 4 \\
\hline July 1820 . & - & 58 &, & 81 & 4 & , & 5 & 2 & 3 & 6 &, & 6 \\
\hline Jan. 1821 . & . & 40 & , & 62 & 3 & , & 4 & 0 & 3 & 2 & , & 4 \\
\hline July 1821 . & . & 36 & , & 63 & 2 &, & 3 & 4 & 2 & 8 &, & 3 \\
\hline Jan. 1822 . & - & 30 & $"$ & 66 & 22 & , & 3 & 2 & 2 & 0 & , & 30 \\
\hline July 1822 . & - & 30 & $"$ & 56 & 110 & , & 2 & 6 & 2 & 0 & $"$ & 210 \\
\hline
\end{tabular}

2 The following illustration from 'A Letter to a Member of Parlia- 
the general revival of trade, yet the period left its mark not only in the extinction of small landowners, but in the retrogression of farming. On heavy clays less capital and less labour were expended; wet seasons prevented farmers from getting upon their land, and led to the discontinuance of manure, excessive cropping, and the impoverishment, even the abandonment, of heavier soils. Wages had been lowered and labourers dismissed; Swing and his proselytes were at work, and in 1830-1 agrarian fires blazed from Dorsetshire to Lincolnshire. To add to the difficulties of the clay farmer, the rot of $1830-1$, which is described as the most disastrous on record, 'swept away two million sheep.' Much of the land was in miserable condition. Ploughed up when corn was high, it was badly laid down again when prices fell. Some was cultivated as 'up and down land,' tilled for two or three years, and then abandoned, according to variations in the price of wheat. A general want of confidence prevailed between landlords and tenants, and recent experience created a profound distrust of leases. Rents had been reduced from 25 to 30 per cent., and large arrears had accumulated; poor rates

ment' is interesting as showing some of the ordinary expenses of living in $1822:-$

A person has an estate of, per annum . . . . $\quad \begin{gathered}f \\ 500\end{gathered}$

(His family consists of himself, wife, four children, one man and two women servants.) $f^{£}$

Education of his children with their clothing . . 160

Assessed and parochial taxes . . . . . 30

Servants' wages . . . . . . . . 25

Own and wife's clothing . . . . . . . 35

Deduct a third of his income . . . . . . 166

Remain to bear the expenses of housekeeping, sc. 81 What is to become of this class and all under? 
were enormously increased. Farmers on light lands suffered comparatively little. Prices were low; but the spread of drill husbandry, artificial manures, better rotations of cropping, and improvements in the breed both of cattle and sheep enabled them to farm with profit. A good machine was driving out a bad one. Fifty years before, clay lands were the corn and beef producing districts of the country, while the light soils of Norfolk lay uncultivated. Now the parts were reversed. This revolution in farming had been mainly effected by turnips, and only drainage could enable clay farmers to hold their own against their rivals. The Commission which was appointed in 1836 received evidence upon the condition of the landed interests. They made no report, but the majority of the witnesses confined the distress to clay farmers. Signs of returning prosperity became faintly visible. Mannfacturing progress began to tell upon agriculture; the new system of poor laws had already reduced the rates; wool, mutton, and beef had risen in price; barley and oats were selling briskly and at higher rates: wheat was low, but the price resulted partly from defective harvests in 1838 and 1839, partly from improved and extended cultivation. The ' rebellion of the belly' at Birmingham and Newport (Mon.) in 1839 and at Sheffield in 1840 was the result of the rise in prices by which the farmers profited.

The drainage of clay farms was the crying need of the day, and the Tithe Commutation Act of 1836 encouraged landlords and tenants to expend capital without fear that tithe-owners would share the profits. At the nick of time science provided the necessary means.

Drainage had been ably discussed by Walter Blith in 1641, and it had been insisted upon by Young as a necessary preliminary to agricultural improvement. But 
hitherto farmers had been baffled by insuperable difficulties. Over-wetness, which arose from water issuing to the surface in consequence of subterranean interruptions to its course, had been admirably dealt with by a Warwickshire farmer named James Elkington at the close of the eighteenth century. His services in tapping springs were in great request in the midland counties, where his crowbar was compared to the rod of Moses. He received a Parliamentary grant of a thousand pounds; but his success so largely depended on experience, that his secret was bnt imperfectly reduced to rules by Johnstone. ' Only springy or sponty land was drained, and only those spots which were considered dangerous to cattle. A trench was cut deep enough to reach the bed along which the water filtered before it encountered the obstacle that forced it to the surface, and was then filled with stones to within $2 \frac{1}{2}$ feet of the surface. But in draining the soil of its surface water the ordinary method was to throw the land into ridges from two to four feet high. As the headlands were often similarly dammed up, the furrows became standing pools of water. The height of these ridges was sometimes extraordinary. In Gloucestershire, while Marshall stood in a furrow, a man of middle height, crossing the field towards him, was lost to sight in every furrow. But this practice served other purposes besides drainage. On grass lands it provided a variety of herbage. Many farmers believed that it increased the surface. It was also employed on light chalky loams where it was not required for warmth or dryness, because in common fields continually fallowed, if the lands had lain flat, the soil would have been run together like lime

${ }_{1}$ An Account of the most improred Mode of Draining Land according to the System practised by Mr. James Elkington. By John Johnstone, Land Surveyor, Edinburgh, 1797. 
by a 'pash' of rain. The effect of this drainage was to wash the soil bare from the ridges into the furrows, and thence into the adjoining stream; thus the high parts were too poor, and the lower too wet, to sield crops. If the rain descended with any force, it ran along the surface, carrying with it the manure and the richness of the soil. Every river flowed turbid after a storm, laden with the wealth of the land.

The discoverer of the science of thorough drainage was Smith of Deanston. It had indeed been extensively practised in Essex, Suffolk, and Leicestershire, where land was drained by trenches filled up with haulm, ling, straw, or turf, and covered over. The practice of this system has been traced back in Essex to 1644; but in the nineteenth century it liad hardly travelled out of the eastern counties. Smith of Deanston had watched the effect of turf furrowdrains in carrying off bottom water on the flat clay lands of Stirlingshire. In 1806 he went to reside in Perthshire. There it occurred to him that the same system might be employed to carry off the surface water which stagnates on clay soil, rendering the land cold and tenacious in wet seasons, hard and unworkable in dry weather. In 1823 he began to try the experiment on a small farm at Deanston, and from 1834 onwards made known his extraordinary success to agriculturists.

The advantages of his system were at once evident, and now scarcely need remark. The soil cannot retain by attraction more than a certain amount of water; it must get rid of the rest by evaporation or superficial discharge. If the water runs off the surface, the land is deprived of one of the richest of fertilising agencies. Not only is rain heavily charged with ammonia, carbonic acid, and other gases, but it is the only carrier of heat downwards. The 
land is also robbed of its own natural fertility as well as of artificial means for its enrichment. If the soil rids itself of the surface water by evaporation, its temperature is chilled. A wet cloth wrapped round a bottle in hot weather acts as a refrigerator; the same effect is produced upon the soil by evaporation. But Smith's systen made rain a friend and not an enemy. In winter undrained land is saturated with water; in summer, baked so as to exclude all air; in frost, bound in a coat of iron. The object of Smith was to change the texture of the soil, to draw off the water and admit the air, and thus to communicate that divisibility and mellowness which farmers call friability. Drainage gave the farmer twice as many days on which he could work his land; it increased the efficacy of his farming operations and of his manures; it secured an earlier seedtime and an earlier harvest, raised the average produce, and lessened the expenses of working. On pasture land its benefits are not less obvious. Drainage destroys coarse aquatic plants, increases the sweetness and nourishment of the herbage, and affords a full bite to cattle weeks before undrained land.

Much remained to be effected in the details of drainage after Smith had demonstrated its principles. But within the next ten years Josiah Parkes (1843) had brought his practical and scientific knowledge to bear upon the subject, the necessary appliances had been simultaneously provided by Reed's cylindrical pipes (1843) and Scragg's machine (1845) for their manufacture, and the necessary capital was offered to landlords upon easy terms by loans provided under the Act of Parliament of 1846.

Drainage chiefly helped one class of farmers, new manures assisted all. In the infancy of agriculture little or no attention was paid to the use of manure. Fitzherbert 
and 'Tusser hardly mention the subject. Plat is the first writer who treats of it at any length. Salt sand, salt water, salt weeds, and everything of a saline quality had been strongly recommended by Gervase Markham in his ' Farewel to Husbandry,' written in the reign of James I. ; Gabriel Plattes considered that 'sal-amoniake' formed a good mould in which to set corn; the use of salt had been urged upon farmers by Lord Bacon. But, as a rule, a little half-rotted straw was the only substance used. On the sea-coasts farmers might employ seaweed and sand, but the prohibitive prices of land carriage prevented their use in the interior. Lime, chalk, marl, crag, gypsum, rags, coal ashes, and the sweepings of London streets ${ }^{1}$ were used by farmers who found their natural manures upon the spot; but their use was necessarily local. 'Nothing like muck' was the proverbial saying, because nothing but muck was obtainable. The one exception up to this time was bone, which had created a new industry. Now, however, as railways cheapened costs of conveyance, and drainage enabled the soil to benefit by fertilising substances, science provided portable means of enriching lands. Sprengel led the way by investigating the properties of soil, and Liebig brought chemistry to bear on the composition of new stimulants in the shape of manure. From 1835 onwards the use of nitrate of soda and guano gradually spread. The manufacture of British guano supplied a cheaper and hardly less valuable substance than its Peruvian rival. In

1 The manures enumerated by Hartlib (Legacy, 1652) are-'(1) Chalke ; (2) Lime; (3) Ordinary dung; (4) Marle; (5) snaggrett [shelly earth from river beds]; (6) Ouse from marsh ditches; (7) Sea Weeds; (8) Sea Sand ; (9) Folding of Sheepe ; (10) Ashes ; (11) Soote ; (12) Pigeon's and hen's dung; (13) Malt dust; (14) Salt and lime; (15) Grassy turf and brakes; (16) Fish; (17) Urine; (18) Woollen rags ; (19) Denshyving, or paring and burning ; (20) Mixing of lands ; (21) Lupines, and ploughing green plants into the ground.' 
1840 Liebig recommended, and in $1849 \mathrm{Sir}$ John Lawes obtained superphosphate of lime by dissolving bone-dust in sulphuric acid. ${ }^{1}$ Geology contributed its quota. In 1843 Professor Henslow proved that coprolites, similarly dissolved, would produce the required superphosphate. Eight years later Odams showed the value of the blood and refuse of London slaughterhouses. The use of guano, phosphatic, and ammoniacal manures completely revolutionised the old rules of cropping. It stimulated not only produce, but drainage. Manures and drainage acted and reacted upon one another; the first encouraged the second. Both together enabled farmers to carry more stock, and taught the lesson that he who puts most into the land gets the most ont. Manure, like charity, proved a blessing alike to the giver and receiver.

Other changes helped to mitigate the force of the blow from which English farming tottered. Railroads, steam navigation, joint-stock banks, assisted agriculturists in their difficulties. Parliament passed Acts for the Amendment of the Poor Law, the Commutation of Tithes, the Repeal of the Beer Duty, the Enfranchisement of Copyholds, the Enclosure of Common Fields, and reduced forty millions of taxation. ${ }^{2}$ Agricultural implements were improved or more widely diffused. Small's plough, the subsoil plough, Meikle's threshing machine, and the drill machine rendered labour more effective. The art of 'setting corn' is said by Sir Hngh Plat to have originated with a 'silly wench,' who accidentally dropped some wheat seeds

1 The declared value of bones imported into the country in 1814 was under 550l. In 1837 it had risen to $255,000 l$. In 1815 the quantity of rape cake and linseed cake was only $16,000 \mathrm{cwt}$.; in 1837 it rose to 800,000 tons. In 1841 the guano imported was only 1,700 tons; in 1847 it amounted to 220,000 tons.

2 The poor rates fell in England from 6,317,255l. (1834) to $4,044,741 l$. (1837). 
in holes into which she ought to have dibbled carrots and radishes. Tull suggested a machine for the purpose; but even in 1788 drills were only 'getting into use' in the first agricultural counties, like Norfolk and Suffolk. 'Mine,' says Mr. Samuel Taylor in that year, ${ }^{1}$ " was one of the first invented.' The inventor was the Rev. Mr. Cooke, and it made its first appearance at Aspul, in Suffolk. But, adds Mr. Taylor, 'it was at this time rare to see a piece of drilled corn.' In 1839 the use of an improved implement was explained to the Royal Agricultural Society as 'a machine to lay the seeds in regular rows;' but it made its way slowly into general use. New attention was paid to plants and grasses. It was now ${ }^{2}$ that swedes, cabbages, and Kohl rabi were cultivated, and that the mangel-wurzel was introduced. Dr. Chevallier cultivated selected and assorted qualities of barley seed; Colonel Le Coutenr, in Jersey, did the same for wheat, and the Lawsons in Edinburgh for grasses. During the same period veterinary science made gigantic strides, and valuable stock was no longer sacrificed to ignorant quacks. County societies were formed for the extension of agricultural knowledge, and the encouragement of stock-breeders by cattle shows. In 1819 the Board of Agriculture had expired: the formation of the Royal Agricultural Society in 1838 marks the revival of better times. The first meeting of this society, which was designed to act as the heart of agriculture, was held at Oxford in 1839. Neanwhile the schoolmaster was abroad, and in 1842 the Royal Agricultural College at Cirencester and the Agricultural Chemistry Association were founded.

1 Memoir of Samuel Taylor of New Buckenham, Norfolk, reprinted from the F'armer's Magazine, April 1841.

= Both swedes and Kohl rabi are mentioned by Young at the end of the previous century. 
Nor were the inflated prices of the war without permanent advantage to the agriculture of the county. The history of farming in Northumberland strongly illustrates this brighter aspect of a gloomy period. John Grey of Dilston, ${ }^{1}$ the Black Prince of the North, one of the most skilful and enterprising agriculturists of the day, played a conspicuous part in the change. Born in 1785, and early called, through the death of his father, to the management of property, he lived in the midst of the agricultural revolution. When his father first settled in Glendale the plain was a forest of wild broom. He took his axe, and, like a backwoodsman, cleared a space on which to commence his farming operations. The Cheviot herdsmen were then described as 'ferocious and sullen,' the people as meducated, barbarous, and ill-clothed. The country was wholly unenclosed, without either roads or sign-posts. The cattle were lost for days in the forests of wild broom. But the character of the soil, on which landlords alternately plundered or starved, attracted skill, enterprise, and industry. Men of the same stamp as the Messrs. Culley settled in its fertile vales, and by their spirited farming revolutionised whole districts which, like the rich vale of the Till, were wildernesses of underwood. The value of land was doubled, if not quadrupled, by the use of turnips and artificial grasses upon tracts which had previously produced naked fallows, or crops of peas choked with weeds. Money made by farming was eagerly re-invested in the reclamation of wastes; commodious buildings were erected, new roads were laid out, threshing machines, worked by water or by horses, were introduced as flails proved too slow a process for the increased produce. During the wars of the French Revo-

1 Memoir of John Grey of Dilston, by Josephine E. Butler. Edinburgh, 1869. 
lution profits increased rapidly, and with them rose competition and rents for land. Long leases were given and large farms, and every rood of soil was put in requisition; large stones were dug up and removed in order to obtain an arable surface; bogs were drained, and open lands enclosed. The fail of prices brought reductions of rent, failure of tenants, changes of ownership and occupancr. But the high state of cultivation which was stimulated by unexampled prosperity was maintained. A substitute for high prices was provided by the increased produce which resulted from manure, drainage, subsoil plonghing, and other results of the union of science with practice.

Similar changes might be noted in almost every county. One other instance will suffice. Before Mr. Pusey's Committee on Tenant Right in 1848 a witness was asked what had been the increase of produce in Lincolnshire in consequence of improred farming. He replied: "The increase has been from almost nothing to thirty-two and thirty-six bushels of wheat to an acre. It was formerly little more than a rabbit warren, only thirty-five years ago.' 


\section{CHAPTER X.}

SCIENCE WITH PRACTICE, 1845-1873.

The year 1845 divides the two periods of 'Science with Practice.' It inaugurated a new era. It marks the transition from farming by extension to farming by intension. Hitherto British farmers had mainly supplied the wants of a growing population by increasing the area of cultivation. After the General Enclosure Act of 1845 they were practically excluded from this resource. They could only meet new demands by developing to the utmost the productiveness of the soil. It is true that within the last forty years upwards of 800,000 acres have been taken into cultivation in England and Wales; but this increase is counterbalanced by the agricultural land which has been occupied by the growth of towns, roads, and railways. The farming area remains, roughly speaking, what it was in 1845 . Between 1801 and 1851 the population of Great Britain and Ireland increased by ten million new claimants for food, and the old supply of land was supplemented by four million additional acres. After 1845 British farmers were driven to depend for profits upon high farming. For the next thirty years they held their own by superior science against the vast corn-fields of Russia, the virgin soils of America and Canada, the alluvial plains of Egypt, and the favourable conditions of labour which enable India to grow grain with unequalled cheapness. During that period 
home-grown wheat was not displaced, but only supplemented by imported corn; the production of wheat did not decline, nor was its place supplied by foreign produce; imports did not increase faster than consumption. The serions question to be considered is whether English farming in 1888 is still in this position.

So long as Protection lasted, landlords and farmers were unable to resist the gambling spirit which it fostered. An upward tendency in prices raised rents and enconraged reckless competition for farms. But latterly the rise of prices proved only the flicker which precedes extinction. Corn-law rents and free-trade prices ruined farmers; Peel's sliding scale of 1842 gare them no relief; the reduction of their labour bills revived incendiarism. Finally, in 1846, Protection was abolished, and England adopted the principle of Free Trade. A period of great distress followed, in which rents were completely revised. Adverse seasons and fear of the consequences of free trade intensified the crisis. Mr. (now Sir James) Caird's pamphlet on 'High Farming the Best Substitute for Protection, "which was published in 1848, suggested the true remedy. The cessation of the free-trade panic, the revival of confidence, the diffusion of agricultural improvements, the expansion of trade, the increase of the precious metals owing to the discovery of gold and silver mines in Australia and California, and the Crimean war, helped the landed interests out of their difficulties. The cost of living, as regards the working classes, lessened; the raw materials of manufacture were cheapened; the rate of discount was lowered; new markets opened in the East, and the increase of our merchant shipping diminished the cost of transport. For the next fifteen years England enjoyed peace while Europe and America were at war, and the full effect upon prices of a free-trade 
policy only began to be felt in 1873. From 1846 to 1877 no proposition to inquire into the state of agriculture was laid before Parliament, if we except the inquiry into tenant right of 1848, and into land improvements in 1873. After the Crimean war the rentals of land rapidly and steadily increased; between 1857 and 1878 they rose not less than 20 per cent.; and the capitalised value of the increase was calculated at upwards of 260 millions.

This prosperity was claimed by the Manchester school as their achievement. Apart from the impulse of despair which it gave to farmers, there can be no doubt that free trade encouraged the best form of high farming. Corn fetched so low a price that, regarded as a separate department, corn-growing ceased to pay. But the rise in the price of meat enabled farmers to grow corn at a profit in conjunction with stock-feeding. Free trade forced them to adopt a mixed husbandry of corn and cattle, and made corn pay through the interrention of green crops and live stock. Here, again, the question now to be considered is whether these favourable conditions still exist. There can, it is feared, be but one answer. 'Down corn, up horn,' was the principle on which farming profits depended. Now both are down together. After the adoption of free trade the farmer's chief resource was to sell corn in the shape of meat; but the recent fall in the prices of stock has checkmated his industry.

The period from 1812 to 1845 had witnessed the preparation for, rather than the adoption of, high farming. The reports made to the Royal Agricultural Society in the early years of its existence, the letters of Sir James Caird as 'Times' Commissioner' in 1850, the letters of the Commissioner of the 'Morning Chronicle' in the same year, the evidence given before Mr. Pusey's Par- 
liamentary Committee on Agricultural Customs, supply abundant materials for estimating the progress of English farming since the Commissioners of the Board of Agriculture published their Reports from 1800 to 1812. The general impression made by the comparison is that farmers, speaking generally, had made but little use of the new materials of agricultural wealth which science had placed at their commancl. In each county high farming was rather the exception than the rule; at least one-half of the occupiers of land had made little advance upon the open-field farms of the eighteenth century. The characteristic of the period $1845-73$ is not the invention of novelties, but the wider diffusion of the best practices.

The repeal of the corn laws acted as a spur to the energies of farmers; and from 1853 to 1873 they were encouraged by a succession of prosperous seasons, to which the years 1866 and 1867 were the chief exceptions. If harvests were deficient, farmers were consoled by high prices. Wheat during the twenty years succeeding 1848 averaged little below the prices of the last twenty years of Protection, and the last six years of the period approached them even more closely. ${ }^{1}$ The Crimean war and the civil war in America stopped supplies from the Baltic and the New World; the great demand for grain for France raised the markets in 1871; the heavy rainfall and deficient harvest of 1872 brought wheat to $57 s$. per quarter; and thus foreign imports, though relieved in 1869 of the shilling duty, failed to force down the prices of English grain. At the same time the ravages of the cattle plague raised the prices of meat in 1872-3 to a figure which

${ }^{1}$ For 20 years preceding 1848 the arerage price of wheat was $57 s .4 d$.

For 20 years succeeding 1848

For five years $1869-70-71-72-73$

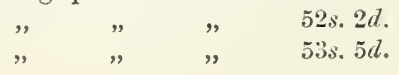


rendered stock-feeding and corn-growing highly remunerative. ${ }^{1}$ Even when corn was low the high prices of meat maintained the balance.

It would be a tedious because monotonous task to enumerate in detail the improvements effected in agriculture during this period. Roots and artificial grasses remained the great pivots of ligh farming. They enabled the farmer to keep more stock, enrich his land with more manure, and thus trebled the growth of corn by bringing into use not only rich soils, but light lands which had been previously valueless; they drew his attention to comparative degrees of maturity in sheep and cattle, and led him to devote himself to breed, precocity, and fattening propensity; they compelled tenants of stiff wet lands to drain carefully and thoroughly; they revolutionised the old systems of cultivation by demonstrating the advantages of autumn tillage. Not last nor least of their merits is the continuous employment they provide for agricultural labourers, who are no longer dismissed at the approach of winter, but earn their wages all the year round. Fresh

${ }_{1}$ Average Prices of Butchers' Meat (per stone of $8 \mathrm{lbs}$.) at the Metropolitan Cattle Market for 1843-6 and for 1870-3.

\begin{tabular}{|c|c|c|c|c|c|c|c|c|}
\hline \multirow[t]{2}{*}{ Years } & \multicolumn{4}{|c|}{ Bensts } & \multicolumn{4}{|c|}{ Sheep } \\
\hline & Inferior & 2ud class & 3 rd class & 4th clas & Inferior & 2nd class & 3 rd class & 4 th class \\
\hline & s. $\quad$ d. & s. $d$. & s. $\quad d$. & s. d. & s. d. & s. $\quad d$. & s. $\quad d$. & s. $\quad d$. \\
\hline 1843 & $2 \quad 8 \frac{3}{4}$ & $32 \frac{1}{2}$ & 37 & $\begin{array}{ll}3 & 10 \frac{1}{4}\end{array}$ & $\begin{array}{ll}3 & 0 \frac{1}{2}\end{array}$ & 3 & 310 & 41 \\
\hline 1844 & $27 \frac{1}{4}$ & 31 & $3 \quad 5 \frac{3}{4}$ & $310 \frac{4}{4}$ & $211^{2}$ & $3 \quad 5 \frac{3}{4}$ & $38 \frac{1}{4}$ & $40 \frac{1}{2}$ \\
\hline 1845 & $2 \quad 9 \frac{4}{4}$ & $35 \frac{1}{4}$ & $39^{4}$ & $4 \quad 1 \frac{1}{4}$ & $3 \quad 4 \frac{1}{4}$ & $\begin{array}{ll}3 & 10 \frac{1}{4}\end{array}$ & $3 \frac{7}{4}$ & $49^{2}$ \\
\hline $1846^{\circ}$ & $28^{4}$ & $31 \frac{1}{4}$ & $3 \quad 7 \frac{1}{4}$ & 40 & $\begin{array}{ll}3 & 7 \frac{4}{4}\end{array}$ & 41 & $5 \frac{1}{2}$ & 410 \\
\hline 1870 & $\begin{array}{ll}3 & 7\end{array}$ & $4 \quad 4 \frac{1}{2}$ & $411 \frac{1}{2}$ & 4 & 3 & $4 \quad 2 \frac{3}{4}$ & $5 \quad 03$ & $7 \frac{1}{4}$ \\
\hline 1871 & $3 \quad 11 \frac{1}{4}$ & $410 \frac{\frac{2}{4}}{4}$ & $5 \quad 4 \frac{2}{2}$ & $5 \quad 8 \frac{1}{2}$ & 4 & 410 & $510_{2}^{\frac{1}{2}}$ & $65^{4}$ \\
\hline 1872 & $3 \quad 7 \frac{1}{2}$ & $4 \quad 4 \frac{1}{2}$ & $5 \quad 3 \frac{1}{2}$ & $58^{2}$ & $4 \quad 5 \frac{1}{2}$ & 54 & $6 \quad 2 \frac{1}{2}$ & 68 \\
\hline 1873 & $\begin{array}{ll}4 & 9\end{array}$ & $5 \quad 3 \frac{2}{2}$ & $5 \quad 10 \frac{1}{4}$ & 0 & $2 \frac{1}{4}$ & $\begin{array}{ll}5 & 11\end{array}$ & $6 \quad 6 \frac{1}{4}$ & $69 \frac{1}{2}$ \\
\hline
\end{tabular}


discoveries increased their utility: swedes and mangelwurzels on the one side, spring vetches from the other, fill the gap which intervened between moisture-loving, frost-dreading turnips and later green crops. Geology and chemistry gave their invaluable aid to tillers of the land. Geology taught the reasons which govern the superfluity or the absence of bottom water, furnished definite classifications of soils, ascertained the composition of their different strata, explained the principles that control their capabilities and degrees of fertility. Chemistry reveals by its analyses the elements on which agricultural values of land depend, suggests how to remove differences or supply deficiencies, equalises the characters of soils, restores the properties which different plants exhanst, and, in a word, assists every branch of husbandry, from the manuring of the land to the production of milk, from the growth of corn to the fattening of cattle. The triumph of chemistry is summed up in the system of successive cropping without imporerishment which has been established by the experiments of Sir John Lawes and Dr. Gilbert. Mechanical inventions completed what geology and chemistry had commenced. The soil is not only improved by drainage and artificial manures, but by subsoil and trench ploughs and deeper cultivation; it is more easily tilled by the lighter and better implements which replaced the cumbrous plough with its shoe-like share fitted on to the wooden chip, and which, working at the lightest possible draught, show clean-cut, level-edged, unbroken rectangular furrows. Instead of the hawthorn tree which Markham recommended for a harrow, new implements are adapted for light or heavy lands, as well as clodcrushers, and horsehoes and scarifiers to cleanse the foulness of the land. Thus the soil is better prepared for the 
reception of the seed, and the seed itself is not only better selected and assorted, but it is more effectively sown by drills, which have supplanted the elaborate directions for hand-sowing given by Fitzherbert, and realised the wildest dreams of Worlidge, Evelyn, or Tull. Nor is meclianical invention content to improve the preparation, the tillage, and the sowing of the crops. It also supplies means by which they can be secured. Harresting by hand has given place to mowing, reaping, tedding, and binding machines; cumbrous wagons have yielded to lighter carts; elevators have diminished the labour of stacking; the flail is supplanted by threshing and corn-dressing machines, which not only thresh the grain quicker, but leave less in the straw. Lastly, the application of steam to agricultural implements has immeasurably increased their efficiency, and instead of horse or water power the plough can now be driven, or the corn threshed, by a strength that never tires or slackens. Nor has science confined its efforts to the treatment of arable land. It has done much to improve the management of grass; and in no department of agriculture has it achieved more marked results than in stock breeding and feeding. Stalls and yards which fifty years stood empty were filled with fat or store beasts. More stock was bred; and it is better bred, better fed, and more comfortably kept; while the use of oil-cake enabled the farmer to enrich his store of manure, increase his supply of winter keep, and carry more head upon his farm. And here, too, machinery economises his labour; it crushes his corn, breaks his cake, chaffs his fodder, pulps or slices his turnips, steams or boils his food. Stall-feeding avoids the waste that is inevitable in yards; each animal receives an equal portion of food instead of being starved by the strongest, eats at its leisure, ruminates unmolested, and 
rests undisturbed. Three beasts were fatted upon land which, as pasture, barely supported one. During this period, from 1845 to 1873 , most of these practices and appliances became widely known if not generally adopted. At the same time commodious buildings were erected; holdings were enlarged; small fields were thrown together, admitting light and air to the land, economising the time of the labourer, and saving expenses of repairs and gates.

But the most conspicuous improvement was the change among farmers themselves. The class rapidly advanced as it was recruited from men of skill, enterprise, and capital, open to new ideas, quick to accept new discoveries, able and willing to try experiments. Good roads, good homesteads, good crops, good stock, and good farmers became the rule rather than the exception. The union of science and practice has, in other respects, borne abundant fruit. It has created a new industry, and a new class of persons connected with farming; it has not only increased the amount, but lessened the cost of production, and thus freed the rural population to supply the demand for artisan labour; it has attracted capital into the land, and made the recognition of tenant right an indispensable necessity. Between 1851 and 1881 agricnltural students increased from 104 in 1851 to 728 in 1881, agricultural implement proprietors and workers from 55 to 4,260 , the land drainage service from 11 to 1,695 . On the other hand, though the produce as well as area under cultivation is greatly increased since 1801, the agricultural population has declined. In 1811 it was 34 per cent. of the whole; in 1821,32 ; in 1831,28 ; in 1841,22 ; in 1851,16 ; in 1861 , 10 ; in 1871, and still more in 1881, not only relatively but actually the total number ${ }^{1}$ of agricultural

1 See Appendix VII., Census Returns of Agricultural Classes. 
labourers has considerably decreased. Whether this result is satisfactory may be donbted; but it is indisputably a remarkable proof of the progress of scientific agriculture. Another sign of the change is tenant right. In the days of Protection English farming was conducted upon a system which required little or no capital. Farmers brought nothing upon their holdings in the shape of costly manure or expensive feeding stuffs; they laid down no pipes for drainage, and used no manure bejond that which was produced upon the farm; their premises were dilapidated and poverty-stricken. They themselves were men of little enterprise, capital, or intelligence, farming by rule of thumb and from hand to mouth, investing in no inprovements, aiming at nothing more than to make both ends meet. The essence of ancient tillage was exhaustion followed by fallow. Nothing was spent in replacing the productive qualities which the crops had withdrawn. All this was now reversed. The essence of the modern system was restoration of fertility; and tenants had at their command a host of resources, the use of which entailed a large expenditure of capital without immediate profits. High farming extracts more from the land; but it also puts more into it and increases instead of diminishing its value. Common law gave no compensation to outgoing tenants except for their way-going crops, and everything affixed to the soil belonged to the landlord. Under such circumstances tenants had little encouragement to expend money in manures, drainage, or a course of skilful farming : without capital, improvements were impossible; but capital is proverbially too shy to be attracted where no security is forthcoming. The necessary outcome of the changed system of farming had been recognised by Mr. Pusey in 1848. Before that time the cry for tenant right was un- 
heard, not because greater confidence existed between landlord and tenant, but because the protection of the right was not required. Three-quarter's of a century ago tenants were not compensated for their outlay because outlay was never made, or because profits covered the risk. From 1800 to 1820 land was clayed, chalked, or manured without any security for the tenant's outlay. The 'custom of the country' intervened on his behalf, but partially and ineffectually. It was proved before the Parliamentary Committee of 1848 that in three counties only, Lincoln, Leicester, and Glamorgan, did the custom of the country afford the tenant any redress, if he received a notice to quit before he had repaid himself for his outlay, or found his rent raised upon improvements which he had himself effected. Even then it was doubtful whether the prevalent usage of the district could have been successfully pleaded in a law-court, though it was often accepted in arbitrations. The demand for tenant-right, which has resulted in the Agricultural Holdings Acts of 1875 and 1883, is rather a significant proof of improved farming than of distrust between landlords and tenants.

To this same period appropriately belong the first records of practical and experimental agriculture. In 1864, upon the motion of Sir James (then Mr.) Caird, it was determined to procure statistical information respecting agriculture, the acreage under cultivation, and its food supplies, whether bread or meat. At first considerable difficulty was experienced, especially in the Midland and Southern counties, in procuring complete returns, which were regarded as portents of increased taxatiou. But the returns are now approximately correct, and have repeatedly proved their value. We are no longer at the mercy of guesswork, which often travels wide of the mark. Arthur 
Young calculated the acreage of England and Wales at forty-six million acres, and Pitt adopted his estimate as the basis of his Property tax. It is now accurately known ${ }^{1}$ how many acres are arable or pasture, what are the crops cultivated, and what the livestock which they carry. And the same information, in less detail, is also supplied with reference to our foreign competitors. Of equal, if not higher, value are the reports of experimental agriculture which are from time to time issued from Rothamsted, the most important station connected with farming in Europe or America. No branch of experimental agriculture or agricultural chemistry can be discussed without reference to the investigations of Sir John Lawes and Dr. Gilbert. It is difficult to estimate the enormons influence which their experiments have already exercised upon farming, or to assign limits to the increased productiveness of the soil which England might have witnessed but for the disastrous period of $1873-87$.

1 From these statistics it appears that the total area of England and Wales is $37,319,221$ acres, of which, in $1887,27,823,207$ acres are under crops, bare fallow, or grass. 


\section{CHAPTER XI.}

AGRICULTURAL DEPRESSION, 1873 TO 1887.

THE causes of the present as contrasted with previous depression are partly new and partly old. The sketch which has been given of agricultural progress shows that a succession of bad seasons or a revolution in the science of farming have produced widespread distress and necessitated changes of front which can only be effected with heavy loss. But the new element now for the first time present is foreign competition.

Though the circumstances are partially new, most of the literature on the subject is old. A large class of persons liave always doubted the reality of farmers troubles. In 1651 Blith said that the chief cause of the depression was the 'high stomachs' of the farmer. In 1816 people argued that if farmers drank sound beer instead of sour claret, and their wives returned from the piano to the dairy, they would still be wealthy. It was reserved for an imaginative poet in 1801 to charge them with soaking fivepound notes instead of rusks in their port wine. Then, as now, the complaint was leard that fundholders escaped taxation. Why, asks a pamphleteer of 1822 , should landowner's, who only get $3 \frac{1}{2}$ per cent. for their purchase, while 'moneyed men' obtain 5 per cent., be despoiled of a third of their income by a taxation which the moneyed interest escapes? Then, as now, the sufferers were not silent. The 
cry was heard that the taxes and the prices ruined farmers, and it was maintained in 1816 that wheat could not be grown at a profit under 54s., and that, if the tenantry had their lands rent free, they could not subsist under present conditions. Then, as now, political agitators were prepared to use depression to foment discontent. In 1766 a writer says that the 'sober industrious poor' are the real sufferers from high prices; but 'who,' he asks, 'ever heard of any of this character mixing themselves with mobs,' made up of the 'drunken, lazy, and abandoned,' whose case was misrepresented, exaggerated, or rather 'created by certain senseless and injudicious writers in the common newspapers?' In the last century, as well as this, every politician at a coffee-house had his infallible nostrum ; theorists elaborated impracticable schemes, which were supported by the ignorant and used by the factious; oppositions, themselves sitting in the cold shade of poverty, bewailed the miseries of the poor; dowagers at quadrille tables inveighed against the cruelty of Parliament in disregarding the voice of the people ; quiet old gentlemen from the depths of their armchairs recommended military executions of butchers, bakers, poulterers, and fishmongers as the most effective remedy. If we are to believe half what we see in print, times have been as bad before. Let the reflection encourage us in facing present difficulties.

For the last fourteen years the country has been passing through a crisis of prolonged, if not unexampled, severity. Three previous epochs stand out conspicuously as periods of agricultural depression. In the last half of the sixteenth century, at the close of the seventeenth century, and during the years 1813-36, the disordered state of the currency constituted an important factor in the distress. Similarly the distress in 1765-73 was partly due to the excessive 
value which was attached to gold. Similarly, too, the most prosperous era of the present century, 1854-73, synchronised with a large increase of the precious metals consequent upon the discovery of gold and silver mines. The presence of this factor alike in adversity and prosperity suggests that the crisis of 1873-87 is largely affected by questions of the currency. The influx of gold raises prices becanse the purchasing power of mouey is relatively diminished by its abundance, and sellers benefit by the enhanced value of their produce. But it also stimmlates commercial activity, and thus its tendency to raise prices is balanced by increased production and consequent cheapness. So, on the other hand, the withdrawal of large quantities of precious metals necessarily lowers prices, because the dearness of money increases its purchasing power, and consequently buyers gain by the seller's. loss. The passage from this broad and simple principle to its detailed application is bewildering in its intricacy. If, as appears certain, currency questions enter largely into the present depression, it is greatly to be regretted that those who speak with authority on this most recondite subject have not translated their technical language into a tongue which is more intelligible to ordinary understandings.

But it is not contended that the currency alone has produced the present crisis. A glance at the history of the past twenty years reveals, not only what has become of the gold, but numerous concurrent causes of financial depression.

The failure of Messrs. Overend \& Gurney in 1866 was the first symptom of the rottenness of our commercial prosperity. Reckless trading had spread widely. Insolvent firms glutted the markets with goods in order to manufacture credit, and deprived legitimate traders of 
their reasonable profits. Banks engaged in business which lay outside their proper sphere, and linked their fortunes with unscrupulous adventurers. The crash came in 1878, but it had long been inevitable. Events of such magnitude as the Civil War in America, the Franco-Prussian War, and the French payment of the Prussian war indemnity necessarily exercised a prodigious influence on the commercial world. Prices rose inordinately in England during the excited period from 1871-3. To this rise two circumstances mainly contributed. The American War had cut off cotton supplies for four years, and during that period all the old produce was sold off, while an actual scarcity was created. Consequently in 1869 capital flowed into the new channel literally in torrents. So, again, an extraordinary demand was created for coal and iron to develop the railways of Germany and the United States, while the opening of the Suez Canal gave a stimulus to the shipbuilding trade.

In 1873 the reaction came, thongh it did not reach Fingland till a year later, Quantities of capital were locked up in unremunerative railways; taxes had been largely increased to provide for war expenses or maintain huge armaments; reckless speculation had followed the triumph of Germany. A railway pánic set in in America, and disastrous failures occurred at Vienna, as well as in Germany and the United States, and they were followed by a fall in wages and in the prices of coal, iron, and other articles. When the reaction reached England it was aggravated by a series of bad harvests, as well as by the political difficulties to which the revival of the Easteru Question gave rise. In 1875 great failures like those of Im Thurn \& Co., or Alexander Collie, and the default on the Turkish debt aggravated the depression, which was intensified by strikes, 
labour disputes, reductions of wages, and the discharge of operatives. The following year brought no increase of trade, but rather diminished both wages and confidence. Throughout 1877 prices fell; trade shrank and financial disasters became general. But the full extent to which the commercial prosperity of the country was undermined was not suspected till the colossal failures of the Glasgow, South Wales, and West of England Banks in 1878. The country has not yet recovered the blow, although trade now stands on a sounder footing through the drastic purging it has undergone.

It is impossible to determine what proportion of the existing commercial depression is directly due to the diminished and diminishing supply of gold. But a diagnosis of the disease detects characteristic signs of a crisis arising out of the gradual decrease of monetary stock. A sudden exportation of cash may produce a short crisis as severe as it is transient. A slow reduction of the stock of money blights and paralyses trade, produces languor, and stifles energies. One puts a pistol to the head of commerce, the other drains its lifeblood. And these signs are accompanied by an exceptional demand for gold, and a palpable falling off in its supply. Within this period the paper currencies of the United States and European nations were replaced by specie payments. In 1871 the German Empire, which had hitherto adopted the single silver system, adopted the single gold standard with a subsidiary silver coinage ; America hoarded stores of gold in order to resume metallic money; Sweden, Norway, and Denmark substituted gold for silver in their currency. This drain upon the gold of the world, in addition to the ordinary consumption through wear and tear or works of art, was not met by an increased supply. On the contrary, Sir 
Hector Hay's evidence before the Silver Commission of $1876^{1}$ shows that the production of gold was steadily decreasing, and the evidence laid before the Select Committee on Depression of Trade in $1885^{2}$ establishes the same fact. To untrained eyes it also appear's significant that in the years 1877-81 the exports of gold from England exceeded the imports by $11,160,000 l .^{3}$ As gold became dearer, prices fell; its purchasing power increased. and produce was cheapened by the scarcity of the precious metals. At the same time silver was depreciated in value. The resumption by America of a double standard temporarily raised its price, but it fell again, partly absolutely owing to the increased yield of silver mines, partly relatively to the enhanced value of gold. Under ordinary circumstances the silver of the world is absorbed in the East. But the process has been extraordinarily slow. Meanwhile, as it appears to unscientific observers, the English farmer suffers both from the glut of silver and the famine of gold. ${ }^{4}$ The Indian rupee, once worth $2 s$., is now worth scarcely $1 s .5 d$. Corn producers benefit by the fall in paying wages; and merchants importing Indian produce can afford to speculate in the exchange, and undersell home markets. 'The use of a single gold standard possesses undoubted merits, but it is complicated by our possession of an Eastern empire which has adopted the single silver standard. ${ }^{5}$

1 See Appendix VIII. Table 1.

2 Ibid. Table 2.

5 The disturbance in the wheat trade in fact results from the disloca. tion between the values of English gold and Indian silver, though England has the advantage in the exchange. The British currency gives a fixed value of $2 \frac{1}{8} d$. to the grain of fine gold. When the Indian rupee was 1 s. $10 \frac{1}{2} d$., $10 \frac{1}{2}$ grains of fine gold purchased 165 grains of fine silver ; now 8 grains of fine gold purchase the same amount of silver. 
The general depression was aggravated by the collapse of agriculture, consequent, in the early part of the periorl, upon a succession of bad harvests. An inclement autumn in 1872 and an unfavourable spring counterbalanced the fine harvest weather of 1873 , and the crop fell below the average. The harrest of the next year was excellent and abundant, but it was the last of a cycle of prosperons seasons. Wheat began to fall in 1875 , and a succession set in of unsettled seasons with bleak springs and rainy summers. Farmers found everything cheap to sell and dear to buy. The harvests of 1875-6-7 fell far below the average both in quantity and quality. The average price of these three years was $51 s$. as against $57 s .5 d$. in the preceding three years. The potatoes failed, the fruit crop ran short, and the cattle plague was rife. In 1877 land agents began to complain that eligible tenants for vacant farms were scarce. The heavy losses which farmers had suffered from three bad seasons in succession, cattle plague, and scanty hay and root crops, were not compensated by the fine season of 1878. The full force of American competition made itself felt when agriculture at home was already thus enfeebled. The Civil War had delayed the impending pressure; it was now accelerated and intensified by the commercial panic in America in 1873, which drove thousands of the working classes out of trade, and settled them down as farmers in the Western States. A general move was made from the Eastern States towards the West. Land was taken up with extraordinary rapidity; population sprang up with a bound in districts which were unclaimed and minhabited except by the large stockowners, who pastured their herds ou open prairies which now yield abundance of corn. The effect was at once felt in the price of grain. The series of bad seasons 
culminated when the sunless, ungenial 1879 produced the worst harvest within living memory. Meanwhile America enjoyed crops of most exceptional abundance, and, taking advantage of the agricultural collapse in England, flooded the country with her produce. Some conception of her profits may be formed from the ease with which she carried out her resumption of cash payments.

Foreign competition, coming on the back of unprosperous seasons, completed the ruin of English farmers. They were unable to recover themselves, and went from bad to worse. The modern problem is low prices. The margin of profit on the staple produce of agriculture sank to nothing. Wheat-growing ceased to pay ; the keeping of more stock on arable land barely met the expense of artificial food; the reconversion of tillage to pasture glutted the milk market; meat farming suffered from the severe competition of America. Added to all these difficulties was the heavy burden of local taxation; labour was dearer and less effective; men were obliged to be employed where boys had sufficed; railway companies carried foreign goods at preferential rates, which compelled English farmers to pay part of the bill for carriage of their foreign competitors. Many remedies were proposed, some the results of wide, others of limited experience. Each suggestion, fortified by instances of its successful adoption, was recommended to the country at large. Investments in fish-farming or jam-making at the best could afford only local relief. As to this large class of remedies, the most that was to be said was that farmers must sit loosely to routine, and welcome assistance from whatever quarter it came. [No general cure for distress exists, except favourable seasons, increased supplies of money whether metallic or paper, revival of trade, curtailment of produc- 
tion by the shifting of capital, diminution of foreign competition, adjustment of standards of living to decreased incomes, restored courage, and the adaptation of farming practices to new requirements.

Recent seasons proved less inclement, and trade less languid; but two of the principal causes of the crisis operate with scarcely diminished force. Foreign supplies pour into the country in increasing volume. ${ }^{1}$ Agriculture bears upon its face every sign of a depressed industry. The soil remains weakly farmed, undermanned and understocked, partly because capital has dwindled, partly because of the ravages of cattle disease, partly becanse farmers are compelled to realise something, even if sales are premature. Land is going back; it is falling ont of condition, if not out of cultivation, and farmers are too poor, too weak, and dispirited to restore or maintain it. Its produce per acre is diminishing; and the number of sheep has decreased by more than two million since $1875 .^{2}$ High farming at present prices appears waste of money; agriculture cannot hold its own by intension against extension. The progress of centuries seems thrown away; the instrument becomes useless just when it is perfected and able to donble the existing produce of the soil. From every point of view but the farmer's, the brightest spot in the general gloom is the cheapness of food. Free trade has at least secured the country from the horrors of famine.

In the face of past losses and present prices landlords have reduced their rentals to little more than the amount which they reached in 1836. And still 'Let the landlords come down with the rents,' in the apprehension of many, solves every difficulty and closes every argument. Not

1 The growth of this prodigious trade from 1866 is shown in Appendix IX.

2 See Appendix $\mathrm{X}$., Statistics of Agriculture, 1867-87. 
every landlord is a Dives; the majority sit at the rich man's gates. Many of them succeed to land encumbered by settlements and mortgages; they cannot dispose of their property, for land is a drug in the market; rates and taxes swallow up what is left from interest and rent charges, and the so-called landowner becomes an agent between his tenants and the mortgagees and taxgatherers. Anyone who has lived in the country can call up before his eyes numerous families who have curtailed their expenditure, diminished their establishments, let or closed their houses, or become absentees on the Continent. But among farmers arrears, bills of sale, liquidations, bankruptcies kept ever in advance of reductions and remissions of rent. It is, of cour'se, impossible to determine the exact amount of their loss. In 1875 their capital might be placed at something between $230,000,000 \mathrm{l}$. and $260,000,000 \mathrm{l}$; in 1887 it has fallen to below $160,000,000 l$. Where they once employed over $10 l$. per acre, they now scarcely employ $6 l$. The census returns of 1881 in a different way attest their impoverishment. The number of tenant farmers diminished between 1871 and 1881 by 10 per cent., while the great increase in the number of bailiffs shows that many are farming as servants land which they had formerly held as occupier's. Many of those who are still in occupation of land are only holding on by their eyelids in hope of better times, or protection. Up till the last year labourers had suffered least of all by agricultural depression. Their position was, and for those who are employed still is, inmeasurably superior to their condition at the commencement of the century. Their cottages are improved, their wages higher, and the prices of all the necessaries of life lower; they are better housed, better clad, and better fed. But as arable land is converted to pasture, and farmers 
are hard pressed by unremunerative prices, numbers are necessarily thrown out of work, employed half-tine, or crowd into towns to meet an exodus into the country of starving artisans; their El Dorado proves to be the workhouse or worse. The landlord's income is precarious, the farmer's fixed rent an improvident speculation, the labourer's wages an uncertain remmeration. With existing conditions all classes, but especially those engaged in agriculture, are necessarily dissatisfied.

Before considering the many remedies proposed, it may be said that, though State interests override the interests of individuals: though the cultivation and occupation of the soil are matters of national concern; though the limitation in the quantity of land attaches a fancy value to its acquisition and renders its possession a monopoly-no true distinction on the score of ownership can be drawn between real and personal property. Money invested in land and money invested in the funds are equally the fruits of industry, equally entitled to protection. Rights, legally acquired under existing land laws, cannot be disturbed without destroying that security which is the vital breath of nations. Sudden changes, subversive of the social system, rather aggravate than cure existing evils. Freedom of contract is a sounder principle than State interference, and voluntary action more satisfactory than compulsion. Whatever are the remedies applied, they must be consistent with established rights and recognised economic laws. On the one side, the accumulation of large estates in few hands is admittedly an evil ; on the other, the mixture of large, middle-sized, and small holdings is economically and socially the most advantageous organisation. But, unless legislation is ill-considered and revolutionary, no general change can be immediately effected in the occupation or 
even the cultivation of the soil. Wise reform will only affect existing conditions by degrees; it will pave the way for, but not effect, radical change; it will create no artificial class by the stroke of a pen. Relief from agricultural depression must be sought, not in the manufacture of a peasant proprietary by suppression of landlords, but in the restoration of confidence and the consequent attraction of more capital into land, the extinction of all hindrances to the development of high farming, the removal of every obstacle to the wider distribution of landed interests, and above all, the revival of paralysed energies.

Crude panaceas are in vogue at the present day; wild theories are promulgated for the redistribution of English land. In the days of her commercial and agricultural supremacy, England might safely ignore such demands for change. An ever-increasing prosperity postponed the shock of antagonistic interests. But now, when disastrous seasons and foreign competition paralyse the energies of agriculturists, when commerce ceases to expand with sufficient rapidity to employ a growing population, land questions are not merely considered with curiosity, but the exclusive privileges of the few are discussed with deepening eagerness. The assailants of property may be noisy out of all proportion to their numbers; their confidence may rather proceed from ignorance than from the calm of reasoned conviction; they may have given no proof, tested by success, that their schemes are feasible; they may forget that the first and worst sufferers by economic blunders are the poor; but it is idle to ignore the danger of an agitation which has already scared away capital from the land, and renders chronic the enfeebled condition of agriculture. It is easy to distinguish the historical and economical aspects of Irish from English land 
questions; yet the exceptional legislation which has been deemed necessary for the Irish tenantry has already borne fruit in England. The cry is raised, and assidmously encouraged by political leaders, that landlords are a parasitical growth, a remnant of feudalism, a class that reaps what others sow. The misconception is industriously fostered that England is a solitary exception to the universal rule of European landholding. It is maintained with increasing vehemence that God made the land for the people, that land is an ager publicus, which the State has granted to landlords to administer, but which she may at pleasure resume. Men quote with approval Mirabeau's retort to the objection that he could not sell the landed property of the Church-'Not sell it! then I will give it.' 


\section{CHAPTER XII.}

\section{PEASANT PROPRIETORS.}

The chief social and theoretical remedy which is proposed for the existing agricultural distress is the forced growth of a peasant proprietary. The peasant proprietor is the spoilt child of theorists; his artificial creation by the stroke of a pen is the favourite panacea of a large section of land reformers. Towards this end, in one shape or another, all theoretical reforms appear to tend. No one will deny that the spontaneous increase of small owners is socially and politically valuable, or that the aggregation of large properties in a few hands is a source of political and social danger. 'Latifundia perdidere Italiam ;' and it is quite possible that land monopoly may prove the ruin of England. The happiness of a people depends on the distribution, not on the accumulation, of wealth; the larger the proportion of those who enjoy a proprietary interest in the soil, the stronger is the guarantee afforded to the stability of the State. From an economic point of riew it may be donbted whether peasant proprietors are profitable; but the enquiry whether a large or small farm produces most per acre jields in importance to the question-Which contributes most to the sum total of national prosperity?

It is useless to appeal in favour of peasant proprietors to the instances quoted by Mill. His authorities belong to 
an extinct condition of society. At the present day means of communication are easy; agriculture has ceased to be self-sufficing, and has become dependent on manufacture; machinery has been introduced into all farming operations; foreign competition has to be faced. Reports of agricultural enquiries abroad prove that the Continental peasantry are not more capable of competing with prairie farmers and rich, if not virgin, soils than are our English tenantry. The Agricultural Congress at Nancy, which concluded its session in the last week of August 1886, practically decided that ' une seule ressource reste donc aux cultivatenrs qui veulent éviter la ruine, c'est d'élever les rendements de leurs récoltes.' In other words, high farming is the recommendation of the congress.

No country and no system of farming has entirely escaped the present depression. Peasant proprietors have suffered less than tenant farmers, only because they employ no hired labour and grow corn, not for sale, but for their own consumption. For tenant farmers the agricultural crisis is hardly less serious in France than it is in England. The proof lies on every side. Forced sales of stock and rural bankruptcies are numerous; disputes are rife respecting claims to unexhausted improvements; farms are difficult to let, rents are falling, population migrates into the towns, land decreases in value. It no longer pars to grow wheat; flockmasters get nothing for their wool; American pork undersells French produce; the florist of Angers complains of his Belgian rival; the madder of Vaucluse is beaten out of the field by indigo. Wages are rising in a falling market; labour is not only scarce and dear, but it has deteriorated in quality. The younger generation is not, it is said, like the old; lads go off to seek fortunes in towns, or cannot endure, after the gaiety 
of barrack life, the monotony of the country. Girls will not work like their mothers, but become dressmakers or shopgirls. In France, as in England, politico-economical questions are chained to the car of party politics; no one dares to inrestigate the principles which regulate commercial dealings. In France, as well as in England, a new privileged class has been created, that of the rentier, who escapes the taxation which crushes the agriculturist. As in England, so in France, through railway rates are said to favour the foreigner; and in both countries the cry grows louder that the cheapest loaf becomes the dearest when no one has money to buy it. If French peasants and tenant farmers have suffered less than their English brethren, it is becanse the land has never been called upon to produce two gentlemen's incomes, and because large employers of labour are nerer ashamed of the blouse and the sabot. In Germany, again, the business of farming is in a most depressed condition. A United States consul of great experience reports that farming properties in districts which are remote from large cities, and where the consumption of milk and other perishable produce is small, may be purchased at fifty per cent. of their former value. Farmers who bought land at the high prices of 1871-74, have sunk half the capital thus invested; those who raised the purchase-money on mortgage have suffered still more. The canse of this downward tendency is the low price of corn and cattle. Increased import duties have not directly benefited farmers. It is only under the new tariff law, which provides that a portion of the income derived from income duties shall be paid over to district authorities, and credited against their bills for local taxation, that they gain by the taxes on produce. A programme was adopted by a farmers' meeting at Cassel in 1883, which 
might have been laid before an English Chamber of Agriculture. The following are some of the measures which were decided upon as vitally necessary to the existence of farmers :-

(1) The diminution of their outgoings by economy in administration, increased liability of personalty, a revision of stamp duties and other charges on land transfer, a tax on stock exchange transactions, an increase in indirect taxation.

(2) The increase of their receipts by protective duties on foreign produce, suppression of middlemen, readjustment of railway rates which favour the foreigner, reintroduction of domestic industries.

(3) The extinction of the land tax; the abolition of the law of succession, which drives peasants to contract debts in order to keep estates together and provide portions for younger children; the provision of cheap loans; and the adoption of a double standard of coinage.

Acre for acre, the English system produces more than the foreign. What reason is there to suppose that the raw agricultural labourer of England, suddenly planted on a cottier farm, will extract more from the soil than his Continental rival, who is favoured by a genial climate, centuries of training, and acquired habits of industry and thrift? The heary rainfall and low temperature of this country narrowly limit the number of agricutural products which are suited to the farming of peasant proprietors, and even confine cereals to a limited area. Under such circumstances it is impossible that peasant proprietors can flomrish universally in Britain. Nor in districts most adapted to their existence can their capital command 
those artificial manures which, to the exhausted fertility of an old country, have become a necessity.

This statement is strongly confirmed by the conditions of agriculture in France. Variety is at once the charm and the solid advantage of France. It is by her diversities of soil and climate that her peasant proprietary thrives. By the same diversity she is protected against foreign competition or adverse seasons. As in England the relations of landlord and tenant farmer constitute practically the only system of land tenure, and corn-growing and cattle-feeding her only agricultural industry, so her districts are purely agricultural or purely manufacturing. It is not so in France, and too much stress can hardly be laid on the contrast. On the one hand, her land tenures are more flexible and more elastic, and her modes of cultivation more diversified, so that all her eggs are not stored in a single basket; on the other hand, agriculture and manufacture are not separated into distinct districts. The squalid hannts of English trade are surrounded at the best by blackened wastes; in French Flanders dense population and high farming advance hand in hand. At the doors of factories, at the brink of coal-pits, is some of the best cultivated land in the world, land which affords recreation and profit to thousands of artisans. 'The importance of this feature in its bearing on the happiness of the industrial population and on the alleged pulverisation of the French soil can hardly be exaggerated. But eren in this favoured country there are certain conditions which are necessary for the existence of a peasant proprietary.

The departments in which large properties are rarest are the following :-Gers, Charente, Haute-Loire, Manche, Lot, in which only 6 to 10 per cent. of the properties 
exceed 300 acres; and Charente-Inférieure, Rhône, Tarnet-Garoune, and Seine. It is impossible to assign any general reasons for the relatively large number of peasant proprietors in these departments. In each different locality much depends on the character of the soil and climate, the special crops, the rate of agricultural wages. Thus, for instance, in Manche, with its unrivalled pastures, its ready markets for eggs, poultry, and butter, its fruit orchards, and its domestic industries, peasant proprietors flourish. Owing to the amount of grass and to the decrease of population, but little agricultural employment is provided. Consequently wages are very high, and selffarming is profitable. The same remarks apply to the neighbourhood of Paris, where the rural population is attracted into the city, and where market-garden produce commands a ready sale. In Rhône, again, where manufacturing industries abound which give employment to thousands of peasant proprietors, tenant-farming is unprofitable, while at the same time the market is good, and the peasant supplements his earnings in the muslin works of Tarare or some of the numerous manufactories of Givors. So, lastly, Charente-Inférieure is well suited to a peasant proprietary. Its soil varies between the reclaimed marshlands of La Rochelle and Rochefort to the valleys and gently undulating plains of Saintes, the well-wooded district of St. Jean d'Angely, or the heathy ground of Jonzac. Peasant proprietors, who number considerably more than half of the adult male rural population, are to be found in the richest districts, where, besides the vine and the ordinary cereals, hemp, flax, fruits, and garden vegetables are grown in great abundance. There is also a large trade carried on in horses. One farmer breeds the colts, the other buys them at six or eight months and 
sells them at two or two and a half years old. Lastly every farmhouse has its still for the manufacture of spirits; large quantities of oil are extracted from walnuts; and the paper-works on the river Touve employ thousands of artisans, who are also small landowners.

In purely agricultural districts, where hired labour is cheap, or in mountainous and barren tracts, peasant proprietors do not thrive. On the other hand, the system of small farms worked by their owners succeeds wherever population is dense, labour dear, manufacturing industries abundant, and markets good for garden stuff, dairy produce, or poultry. The absence or presence of peasant proprietors depends on certain conditions of success, withont which no peasant proprietor is eager to buy the land. They will not thrivo wherever they are planted; a fact which is often overlooked by theorists who point to the French peasant as a proof that owners of land will make gardens ont of deserts. The fact is, no French peasant makes the attempt where it appears useless. If he can command some specially fertilising substance like the seaweed which the Breton peasant collects, or if he enjoys exceptional advantages of climate like that of Roscoff, his industry and energy know no limits, and he will in a few years transform a wild coast into a ceinture dorée. But it is not inland, on barren moors of heath, ling, broom, and stunted pine, that he thrives or even exists. A closer review of French farming than space permits would prove the point that the presence or absence of peasant proprietorship depends on the presence or absence of some essential conditions of success. '

The excessive subdivision of the soil is often urged against the system in France. But the objection is based 1 See 'Rural France,' Edinburgh Rericn, October, 1887. 
rather on the presumed results than the actual effect of the partage forcé; customs have sprung up which so far evade the law as to prevent morcellement becoming pulverisation. Greater objections may be urged against the operation of a law which subdivides the soil on mechanical rules without reference to demand and supply, which splits up estates into minutely scattered parcels, wasting both the soil and the time of the owner, and breeding perpetual litigation. Another formidable danger is the amount of the French peasant's debt. No one is more possessed by the demon of property, more maddened by the soif $d u$ sillon, or more seduced by the fascinations of angulus iste. He raises money, not for improvements, but for additional purchases; he increases his debt with blind recklessness, borrowing often at $7 \mathrm{per}$ cent. from the local Rigou, and becomes proprietor only in name. Yet the mortgages on landed property in France do not amount to half the sum with which land in England is encumbered. In some parts of France the mortgage debt is said to be 80 per cent. of the value of the land, but the general average is only 15 per cent. Balzac's portrait of 'Courtecaisse' is less favourable than Michelet's graphic picture. Perhaps the true condition of the modern peasant lies midway between the two. In actual command of the luxuries of life, the creation of a class of small owners in England would lower the standard of comfort. The French peasant is worse housed and worse fed than the English labourer. His cottage is generally a single room with a mud floor, in which he, his family, and his livestock live, eat, sleep, work, and die; in cold weather he defies all sanitary laws, and makes his room a tank of stagnant air. From morning to night his toil is excessive and prolonged; female labour is the rule; children are continuously employed. 
Progress and education are alike difficult; the rural population often remains ignorant, narrow-minded, jealous, and obstructive.

Holiday writers seem to believe that the French peasant always enjoys summer weather. If Englishmen spend a winter in the country, it is probably in the sunny south. It is not thus that they can understand the melancholy timbre in the voice of the Auvergnat, or the wail of his 'Il faut travailler pour vivre.' No one who has read the 'Satires Picardes' of Hector Crinon, the 'laboureur, poète et sculpteur' of Péronne, can doubt the hardships of peasant life in France. The peasant working in the fields, as Crinon describes him, eats nothing but bread-hard, green, and mouldy-with a beard as long as that of a sapper. The food sticks in his throat, but he has nothing to wash it down. Drenched to the skin with the showers that sweep orer the treeless plains, cut to the bone with the bitter cold, exhansted by a long day's work, he finds nothing ready for his refreshment when he returus home. No fire has been lighted; the water for his soup is still at the bottom of the well; it must be drawn up, the pot put on, and the fire kindled. His soup, when he gets it, is only water with the chill taken off, in which float a few raw regetables. Small farmers are the first in the barn in the winter, the first in the fields in the summer, and the last to leave their work. They only rest in the grave. The sleeping fox catches no hen, and the gain is so small that labour is unremitting. As the ass that earns rarely eats the oats, so the peasant fats fowls for his richer neighbours. 'Pour tout régal nous n'avons que de la flammiche,' a thick dough cake baked on the hearth. For meat he eats once a year, at the 'fête de Pâques,' a small piece of tough, skinny cow beef. At other times his food is cab- 
bage or sorrel soup. His only drink is water. Easier, exclaims the poet, is the lot of the hired labourer. In Brittany many of the peasants live on porridge made of buckwheat without milk, potatoes, rye bread, and buckwheat pancakes without butter. If they are a little better off, they add milk and salt butter, and pork and cabbage two or three times a week. In Berri, Marche, Limousin, Auvergne, and the Cevennes, chestnuts are the staple diet of the rural population converted into a sort of porridge or paste and eaten hot. The fate of the peasant in his old age is often cruel. So long as the old man has not signed the deed of partition, he has the best seat by the fire; no morsel is too choice for him. The moment it is signed, he is regarded as a burden; he is sent out to beg with ragged clothes; the sooner he dies the better. In fact, the French peasant is seldom far from the border-line of starvation; all the product is consumed on the spot; money is scarce, and famine periodical if not frequent. He is rarely well off unless he has other means of support. Many peasants in Belgium combine agricultural with other agricultural pursuits; many in France are agricultural labourers for hire, and eke out their subsistence, as in the Alpes Maritimes, by moneta forestiere; in Hérault they are day labourers who till their own plots of land, or, as their patois expresses it, 'font limpéraou' out of working hours ; in Hautes-Pyrénées they hire themselves out for daily wages; in Tarn-et-Garonne the pagés, as the peasants are called, work in harvest times as estivandiers and solutiers; in Auvergne the ground is tilled by old men, women, and children, while the able-bodied men work in large towns all the summer as porters and water-carriers; so, too, the Limousin supplements the scanty produce of his land by wages earned in summer months as a bricklayer or stonemason. Yet, on 
the whole, the French peasant is less hopeless and more independent than the English labourer; he possesses greater weight in the social scale. Arthur Young was no friend to peasant proprietors, but he says of those in the Isle of Axholme: "Though they work like negroes, they are very happy respecting their mode of existence.' The lot of the French peasant is indisputably hard, his fare meagre, his cottage filthy, his standard of life and education often lamentably low. On the other hand, a peasant proprietary increases the number of those who have something to lose and nothing to gain by revolution, encourages habits of thrift and industry, gives the owner of land, however small his plot, a stake in the country, and a rested interest which guarantees his discharge of the duties of a citizen. Combined with the partage forcé, it checks population, for ' la plupart des Normands n'ont pas lu Malthus, mais ils pratiquent instinctivement ses conseils.'

No one will deny that the system of peasant proprietors is socially advantageous. It affords a training to the rural population for which we in England have found no substitute. It checks the centralisation of pauperism, the overgrowth of population, and the migration into towns. The element of stability which it contributes to the State is more valuable to the French than ourselves. There the towns are inflammable as touchwood, while the country ignites more slowly. Yet even here it is useful to have a class of slow-thinking men, who will answer political firebrands with 'Cela est bien, mais il faut cultiver notre jardin.' But, while conceding the advantages of a peasant proprietary, it is impossible to ignore the inseparable difficulties which beset its establishment in England. The porerty and misery or the wealth and happiness of French peasants are often exaggerated in the interests of poli- 
ticians or of theorists. The small owner is not superior to the ordinary conditions of agricultural success. He will not thrive wherever he is planted, or live on land which starves a rabbit. The chief conditions of his prosperity do not exist in England. We have no commons, no domestic industries, no union of agriculture with manufacture, no special crops for which his minute labour is peculiarly adapted. Some of these conditions can be created; but it is well to bear in mind what is entailed in the establishment of a peasant proprietary, as well as to recognise the duties which such a system throws upon the State.

Finally the example of France is often quoted to prove that a happy and contented peasant proprietary may be established by legislation. The illustration is unfortunate. In the fourteenth century peasant proprietors were numerous in the country, and on the whole increased continuously. In 1697, as Bois-Guillebert states in his 'Détail,' famine compelled them to sell the land which they had painfully acquired in the two preceding centuries. But this check was only temporary. Forbonnais points out that in 1750 impoverished landlords sold their lands to their tenants. Necker states that there were in his time 'une immensité' of peasant proprietors. Doniol ('Histoire des Classes rnrales') says that before the Revolution a quarter of the soil had passed into their hands. Arthur Young goes further when he states that in 1787 a third of the land was tilled by peasant owners. The returns on which the land tax of 1790 was based show that, in many districts, the number of proprietors then amounted to two-thirds of the landowning population. It is a travesty of history to assert that the peasant proprietary of France was created by legislation, inasmuch as it was firmly established under the same land laws which existed in this country. 
On general grounds the proposition can hardly be disputed that an increase in the number of those who enjoy proprietary interests in the land is socially and politically, if not economically, advantageous. But the increase must be obtained by evolution, not revolution. For immediate relief of agricultural distress it is folly to look to peasant proprietorship. None of its advantages can be secured unless its growth is spontaneous. Habits of thrift, industry, and sobriety are formed by centuries of custom and training-they will not spring up like mushrooms in a single night. State legislation opposed to natural laws is as effective as the Pope's bull against a comet. The disappearance of the class in England and its prevalence abroad result from gradual, well-ascertained causes. No argument for its artificial creation can be drawn from agrarian legislation on the Continent, while in every European country it only exists side by side with landlordism. If it can be shown that the difficulty and expense of the transfer of land obstruct the natural growth of peasant proprietors, let the obstruction be removed. Its removal is on other grounds desirable. But the destruction of large estates and the creation of a class of small owners is a more than doubtful experiment of the legislature. Peasant proprietorship cannot be revived without a return to an extinct social system. Reduce population by one-half, revive domestic industries, return commons and wastes to their former barremess, make the farmer independent of manufacture-in a word, restore the conditions of selfsufficing agriculture, and the peasant proprietor may still thrive. Under the present conditions of production, when crops must be sold as commodities for money, it is only under exceptional circumstances that the peasant owner maintains his ground. 


\section{CHAPTER XIII.}

\section{LANDLORDS A NATURAL GROWTH.}

T'He case against nationalisation of land might be rested on the impracticable nature of the object for which it is demanded. If the legislative introduction of a peasant proprietary is condemned as impossible, the broad features of the existing cultivation by landlords, tenant farmers, and wage-earning labourers must remain unchanged. But defenders of this system are challenged by the oft-repeated statement that landlords in this comntry are a parasitic growth. Although the State purchase, or nationalisation, of land is chiefly demanded for the creation of peasant proprietors, time will not be wasted by an attempt to prove the futility of this statement, which is continually used as a rhetorical point.

In France the system of peasant owners and tenant farmers exists side by side, and is the outcome of natural causes and economic laws. France offers no parallel to the commercial exigencies which in England during the fifteenth and sixteenth centuries required the home production of wool, and evicted crowds of small farmers from the land to make room for the shepherd, his dog, and his flock. So, again, the population of France remained stationary, while that of England increased at the rate of geometrical progression; the one country, confronted by 
the practical problem of making bread and meat for the million, concentrated her energies on the wholesale production of corn and cattle; the other, opposed by no such difficulty, developed a different system of land tenure and of farming. The effect of the French movement was to tighten the peasant's grasp upon the land, of the English to tear it from his clutch.

In Belgium, as in France, the relations of landlord and tenant exist side by side with a peasant proprietary. In both countries the peasant owners are the growth of natural laws. In Belgium the largest portion of the land and the most productive and fertile districts are held by tenant farmers. The 'Pays de Waes' is not cultivated by small owners, but by tenants, who have for their landlords the little tradesmen of the towns. The poorest soils, such as the Campine or Luxembourg, are tilled by peasant proprietors. But even in the Campine the farmer ekes out his agricultural earnings by travelling over Europe as a pedlar in human hair.

Both the objects and results of agrarian legislation in Germany have been misinterpreted by English land agitators. Stein and his successors did not expropriate the landlords, or deprive them of their land to create a peasant proprietary. Before 1807 land in Prussia was divided, like society, into three castes; peasant land could not be exchanged for burgher land, or burgher land for noble. The old Teutonic communities occupied the greater part of the land, but the ownership was vested in the feudal barons. Peasants could not acquire more than the dominium utile; the dominium directum belonged to the landlord. They were really serfs, fixed to the soil, irremovable from the manor, holding their land by money rents and personal services. They enjoyed common rights 
among themselves and usufructuary rights over the demesne. Thus, though the soil was divided into a number of individual properties, freehold ownership was practically unknown. The objects and results of Prussian agrarian legislation were to emancipate the peasant from serfdom, release him from the manorial land, and abolish his personal services, to consolidate intersected estates and extinguish common rights. Landlords received as compensation for the release of their serfs a portion of the peasant lands; the peasant retained as freehold a diminished portion of the soil which he had occupied. The Legislature in fact effected a compromise by an interchange of interests. Prussia remains to this day an example of that union of small, middle-sized, and large properties which is economically and socially the most advantageous organisation.

As with Prussia, so with other states in Germany. Between 1817 and 18t8, in Baden, Württemberg, Bavaria, and Hesse, the serfdom of the peasants was abolished by redemption of feudal services; common rights were extinguished, or so regulated as no longer to retard agricultural progress; absolute individual ownership was substituted for common occupation by members of agrarian communities; landlords emerged from the transaction with an increased private estate, and peasants with a diminished but freehold property.

The same legislation has produced with some varieties the same results both in Austria and in Russia, Nor was the legislation which is in Demmark associated with the name of Hansen and 'the peasant's friends' of a more revolutionary character. Landlords abandoned their fiscal immunities and feudal rights, but retained their land. Each estate is now divided into demesne and peasant 
lands. Over his demesne the landlord's rights are unfettered; he leases it to tenants by contracts which the State does not seek to control. But he may not increase this portion from the Böndergaard or peasant lands. The Böndergaard is occupied by peasants who rent from the landlord the land which they cultivate. When leases expire, the landlord is bound to offer the farm at a fair rent. If no tenant accepts the farm, he may parcel it ont among other peasant farmers, or let it in lots to the hired labourers, or absorb it in the demesne on giving an equivalent, or sell it to the peasant tenants. To encourage him in this latter course, he is allowed to annex to the demesne one-tenth of the peasant farm thus put up for sale.

Throughout the Continent landlordism exists side by side with a peasant proprietary; in no country has the State expropriated the landlords; in none has the experiment been tried of an artificial creation of small owners. At the most the State has superintended and assisted the passage from primitive communism and mediæval usufruct to individual ownership. All Tentonic nations started from the same agricultural basis; in all fendalism was a universal featnre; in all the same conflict was waged between the manor and the mark; in all there has been the same transition from common to allodial property. In no country has the land been nationalised; in all proprietary rights are acquired by private individnals; the same system is at work in each, but the results are not identical. Both in England and on the Continent rights of ownership and of usufruct were once vested in different persons. Lords of the manor were lords of the soil, but their profitable enjoyment of every portion except their demesne was limited by the usufructuary rights enjoyed by their tenants. When the primitive germs and natural laws of 
social development are thus identical, it might be expected that results should prove analogous. If England appears to form an exception to rules of development which have elsewhere prevailed, the exception is rather apparent than real. The change which took place on the Continent within living memory commenced in England four centuries ago, and was practically completed before 1800 . Its causes and progress have been already traced in considerable detail.' On the Continent the land problem was solved by the light of the French Rerolution; in England it was determined while the spirit of fendalism still predominated. Yet in Germany in 1810 the interests of the 'Halb-Bauern' were as much overlooked as those of cottagers in England during the sixteenth and eighteenth centuries. What England lost in one direction by the disappearance of a peasant proprietary she gained in another by that early start in the race of commercial prosperity which necessitated the extinction of small proprietors. The higher class of artisans represents the yeoman farmer, and its creation is the direct result of our land system. Neither nations nor individuals can eat their cake as well as keep it. Without large farms, capital, and increased production, it would have been impossible for England to feed her growing population, or to attain her commercial prosperity. No such economic necessity affected the agriculture of the Continent; no industrial changes as yet revolntionised the conditions of foreign society. Buffon's maxim, 'A côté d'un pain il naît un homme,' still held good on the Continent, wlien, in England, population trode on the heels of production, and when peasants were no longer born to the bread on which they lived, but were suddenly required to furnish food for

' See Chapters II., III., V'II., and IX. 
vast centres of manufacturing industry. Abroad population remained stationary; the habits of the people continned to be agricultural; manufacturing classes were comparatively unknown. Consequently, on the Continent, farming retained its self-sufficing character, and the agrarian communities, which belonged to primitive conditions of society, outlived the decay of feudalism.

In England the security, if not the profit, of the investment, together with the social and political advantages which once attached to the possession of land, stimulated capitalists to lay field to field, and those yeomen who still owned the soil either consulted their pecuniary interests by selling their estates, or were.compelled by the widespread ruin of the first half of the present century to relax their hold upon the land. The result is that the whole number of landowners, properly so called, in England and Wales scarcely exceeds at the present time 170,000 persons. No one contends that such a condition of things is sonnd or healthy. But the difficulty of resisting the natural tendency to accumulate land is forcibly illustrated by the report of a Land Commission recently published in the United States. Statistics show that, in a country where estates in fee tail are obsolete or abolished by law, where there is no fendal tennre, no primogeniture, no privileged class-in a country, finally, where the transfer of land is simple, easy, and cheap-large estates and large farms have become the rule. The United States contain more tenant farmers than any other country in the world, and, where this class exists, those who do the drudgery do not own the land. Land monopoly is becoming the system of America.

The course of agricultural history in England has on the whole been governed by natural economic laws; its 
present condition is the result of gradual well-ascertained causes. But the record of the growth of large estates is not so free from the taint of oppression that landlords can appeal with entire confidence to their moral title-deeds. The pancity of their numbers, and the exceptional nature of their position and property, should add no element of insecurity to their possessions; yet they warn landlords to think less of their rights than their duties; they render it essential that no indiridual should fall below the highest standard of the class. It is inconceivable that any serious attack upon legal rights of property should be sanctioned by the law-abiding English nation. No more fatal blow could be struck at that national credit upon which our very existence depends. There is nothing in the examples of foreign legislation, there is still less in the history of the growth of English landed property, to justify the State in violently forcing back or putting forward the clock of social progress, in defying the natural laws of agricultural development, in arbitrarily replacing the peasantry of the country in a position which the majority abandoned nearly four centuries ago, and for the surreuder of which compensation was, in most cases, offered and accepted. Even if State interference were in theory so justified, practical experience does not invariably encourage a repetition of the experiment. Foreign precedents cannot be accepted when favourable and rejected when adverse. In Greece the rent to the State was from the first repudiated; in Belgium the tenants always regarded themselves as State pensioners. Nor is the failure confined to foreign countries. At Snigs End and Minster Lovell the experiment was tried after the Chartist movement. It cannot be said to have succeeded. If it is to be repeated on a large scale, we may once more witness the spectacle of tillers of the 
soil setting up perches for rabbits to roost upon. If economic laws, precedents, history, experience, national justice, and national security still weigh for anything with the legislature, the conversion of the State into a land agency for the immediate and artificial creation of a peasant proprietary may be dismissed to the limbo of crude panaceas and mpractical theories.

Nor should it be forgotten, in the interest of landlords, that all the improvements in English agriculture, which have given us, speaking generally, an undisputed supremacy in the art of farming, have been effected by private capital and individual enterprise. In these days of competition, agriculture must advance or retrograde. Peasant proprietors cannot conduct expensive experiments or invest money in the improvement of stock. If the State creates a class of small owners, it must be at the same time prepared to assume the expenses which have hitherto fallen on private individuals. In France, for instance, where a peasant proprietary exists, the State stands in the place of the landlords. Where properties are large State interference is rarely necessary, because enlightened self-interest generally coincides with public policy. But among a mass of ignorant, small owners, minute, isolated policies prevail, and the State alone regards larger interests. In the eighteenth century, the existence, not merely the commerce, of England imperatively demanded large holdings, owned by capitalist landlords, and let to capitalist tenants. By this means only, when no foreign produce supplemented native resources, could the soil supply food for its vast population. France has felt no such overwhelming pressure of population; no inexorable law of demand and supply has divorced her peasantry from the soil. In England, for public purposes, the State faroured the growth 
of a small class of capitalist landlords. In France the State sacrificed the few to the many, and promoted the increase of small owners standing on the border-line of pauperism. In England the State has left agriculturàl improvement to private enterprise; in France she supplies out of the pockets of the taxpayers the capital and direction in which her land system is deficient. If the present system is abolished in England, the State must not only undertake the expenditure of the landlord, but make the ontlay of the tenant farmer. Peasant proprietors are, in fact, costly exotics, which, in their present surroundings, can only be reared with a certain loss to the community in the general productiveness of the land, a deterioration in their own standard of comfort, and a perpetual expense to the taxpayer.

A glance at some of the leading features of the French system of State aid to agriculture will bring home the lifficulty of creating a peasant proprietary to the breechespockets, if not the consciences, of legislators.

Elementary agriculture is tanght in primary schools, where children learn to distinguish between plants, grasses, and soils; often a plot of ground is attached to the school which serves as an experimental farm. The school teachers are supplied with training in the subject by departmental professors, who, under the direction of the Minister of Education, give courses of lectures in the écoles normales The rest of the system of agricultural education falls under the department of the Minister of Agriculture. Three classes of schools are provided:-(1) the fermes-écoles; (2) the écoles pratiques; (3) the écoles nationales. The fermes-écoles are numerous and useful; among them are those of Trois-Croix, near Remnes; St.-Gauthier, at Domfront; St.-Michel (Nièvre); Nolhac (Haute-Loire). 
Many of these primary agricultural schools were founded by private enterprise after the Restoration, but in October, 1848, they were recognised as part of the administrative system of the State. Lads enter these schools as apprentices, not as pupils. They musi not be over sixteen at the time of entrance; they are fed and treated as labourers; they go through a course of two or three years, and at the end leave the school with a certificate which qualifies them to act as bailiffs. If they show decided aptitude, they may obtain a bursary at one of the écoles nutionales. The yearly cost of each farm pupil to the State is 10l.; the State also defrays the expenses of the salary of the director and his assistants. The director obtains the labour of the pupil for nothing, and manages the farm for his own profit and at his own risk. The écoles friatiques are assisted and superintended by the State. It was intended that there should be one school in each of the twelve regions into which France is agriculturally divided. These agricultural high schools are designed for the sons of the wealthier class of cultivators. The cost is from 400 francs to 500 francs a year. The pupils learn practical agriculture and the elements of physics, chemistry, natural history, botany, veterinary science, and stock-breeding. They have not proved particularly successful; the best known is that of Merchines (Meuse). The three écoles nationales are placed in the centres of three districts of France. They are Grignon, near. Versailles (Ile de France); Grand Jouan, near Nozay (Loire-Inférienre); Montpellier (Hérault), formerly La Saulsaie (Ain). All three schools were founded before the Second Empire-Grignon in 1827, Grand Jouan in 1832, La Saulsaie in 1840. The course of instruction at Grignon lists two and a half years; and each year is divided into 
two terms, the first from October to March 15, the second from Narch 15 to Angust. All the pupils are obliged to pass the entrance examination, unless they have previously taken the degree of Bachelier ès-Sciences. They may be either externes or internes. The externes pay 200 francs a year for their lectures; the internes pay from 1,000 francs to 1,200 francs for their pension and lectures. There are bursaries in each of the three colleges, which are filled up in open competition among the pupils of the farm schools. The Institut Agronomique, which crowns the fabric, forms a faculty of agriculture.

Besides these schools in the general practice and science of agriculture, there are special schools, such as the sheep farm at Rambouillet, the gardening establishment at Versailles, the school of drainage and irrigation at Lézardeau, near Quimperlé, the three veterinary schools of Lyons, Alfort, and Toulouse, and the écoles de dressage like that near Caen. In 1879 departmental professors were appointed, whose duties are twofold. Under the direction of the Minister of Education, they lecture at the normal schools to pupils who are being trained as schoolmasters; under the instructions of the Minister of Agriculture, they hold conferences with the agriculturists, teachers, and proprietors of each canton, perambulate all the country villages to observe agricultural processes, keep in touch the various local societies, and spread the knowledge of improvements. By the law of June 16 , 1879, each department is to be provided with a professor, and their agricultural duties were minutely defined in a circular of M. Tirard in 1881.

Agricultural shows and competitions as well as horseraces are encouraged by the State. The great central show is held at Paris; but, for the promotion of provincial 
competitions, the whole conntry is divided into twelve regions, Algiers forming a thirteenth. These concours régionaux are under the direction of the State, which gives the prizes and pays the expenses of the judges. Agricnltural societies have been formed under State patronage for the departments, the arrondissements, and even for the cantons. Veterinary science is a subject to which the State pays great attention. A veterinary officer is attached to each arrondissement, who has passed through the four years' comrse at one of the three veterinary schools, and has received the diploma entitling him to practise. His powers are considerable. All the foreign livestock is subjected to a veterinary examination at one of the points at which it is permitted to be importer, and only sound animals enter the country. Internally, the existing law contains most stringent provisions for the slaughter of infected cattle. State indemnities are granted to owners of slaughtered animals. The State interests itself in the breeding of horses, cattle, and sheep. The Ministry of Agriculture contains, for instance, a Directeur des Haras, who has under him inspectors general and inspectors. At the Haras du Pin there is a free school, in which is taught every detail connected with the management of horses. There are twenty-one depôts of the great Haras de Pompadour; and more than 2,500 stallions are placed at the disposal of the owners of mares.

Nor is the State aid confined to edncation and the improvement in livestock. Each arrondissement has its Ingénieur des Ponts et Chaussées, who assists proprietors in all drainage operations. In each arrondissement again there is the agent royer, who inspects the roads of the district in his care. There are three different classes of roads, 
the chemin vicinal, départemental, and national. The first class is kept in repair by the Communes, the second by the Department, the third by the State. It is the duty of the road overseer to assess the expenses of the repairs.

Lastly, the State assists works of irrigation, reclamation, and similar improvements, indirectly through the Crédit Foncier, and directly with subventions and loans. It has facilitated means of transport, subventioned the erection of bridges in place of the old ferries, assisted canals, railways, and roads. It has aided in works of imrigation like those of Verdon, near Aix, St. Martory (Haute-Garonne), Lagoin (Basses-Pyrénées), La Bourne, near Valence. It has helped to improve barren wastes by such means as winter submersions in the valieys of the Durance, the Arc, and the Isère. It has attempted to replant the forests, and so check the ruinous floods so common in the mountainous districts of the Alps. It has assisted in the reclamation of La Sologne, the barren tract of heath and furze or sandy wastes diversified with marshy ponds, which formerly belonged to the Orléanais, and now makes up part of the Departments of the Loir-et-Cher, the Cher, and the Loiret. Thirty years ago this district was a desolate thinly populated plain, soppy as a sponge in winter, dry as a cinder in the summer, and so unhealthy that the average length of human life was only twenty-seven years, inhabited by a stunted race whose stupidity passed into the proverbial saying of ' un niais de Sologne.' The State set on foot drainage works, cleaned out the waterconrses, introdnced marl, planted pines, and set an example which has been followed by many proprietors. So, too, it has aided to drain the district of the Dombes (Ain), where grass alternates with water and cattle with fish, and to bring into cultivation the landes of Gascony by pine plantations. 
Are English taxpayers prepared to pay several millions every year in order to try an experiment which, economically at least, is of doubtful utility, and would probably result in establishing as the real proprietor, not the agricultural labourer, but the city money-lender? 


\section{CHAPTER XIV.}

\section{DISTRIBUTION OF LAND.}

IF the State acquisition of the land and its arbitrary redistribution among the class of peasant proprietors be rejected as an extravagant and impossible plan, the broad features of the existing system of land ownership, occupation, and cultivation must remain unchanged. What are the conditions of that system?

The total acreage ${ }^{1}$ of England and Wales under all kinds of crops, bare fallow, and grass was, in 1887, $27,753,207$ acres.

The New Domesday Book ${ }^{2}$ shows that there are 972,836 proprietors of land in England and Wales, holding between them $33,013,510$ acres. These figures may be thus analysed :-

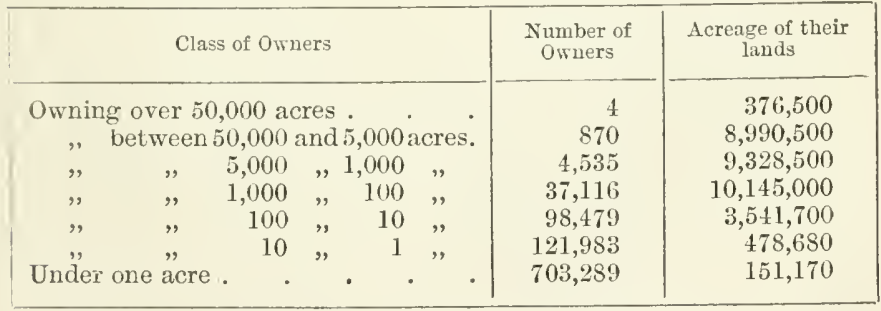

But the returns in the New Domestlay are incorrect

${ }^{1}$ Appendix XI. gives the statistical returns of the crops of England and Wales for 1867,1877 , and 1857, and, for purposes of comparison, fonr other estimates of the dates respectively of $1688,1771,1808$, and 1827.

2 Moved for by Lord Derby in the House of Lords, February 1872. Compiled, 1874-5. 
and misleading; and the following analysis ${ }^{1}$ gives a more reliable answer as to the conditions of land ownership in England and Wales:-

(1) 4,217 persons own, in estates of over 1,000 acres, $18,546,000$ acres.

(2) 33,937 persons own, in estates of between 1,000 and 100 acres, 8,927,000 acres.

(3) 217,009 persons own, in estates of between 100 and 1 acres, 3,931,000 acres.

(4) 14,419 public bodies own 1,443,500 acres.

(5) 703,200 persons own, in holdings of under 1 acre, 151,000 acres.

But even this result leaves a false impression, if it is forgotten that it applies not merely to agricultural but to building land. The number of owners of agricultural land

Number, Acreage, Average Size, and Number of Horses and Livestock

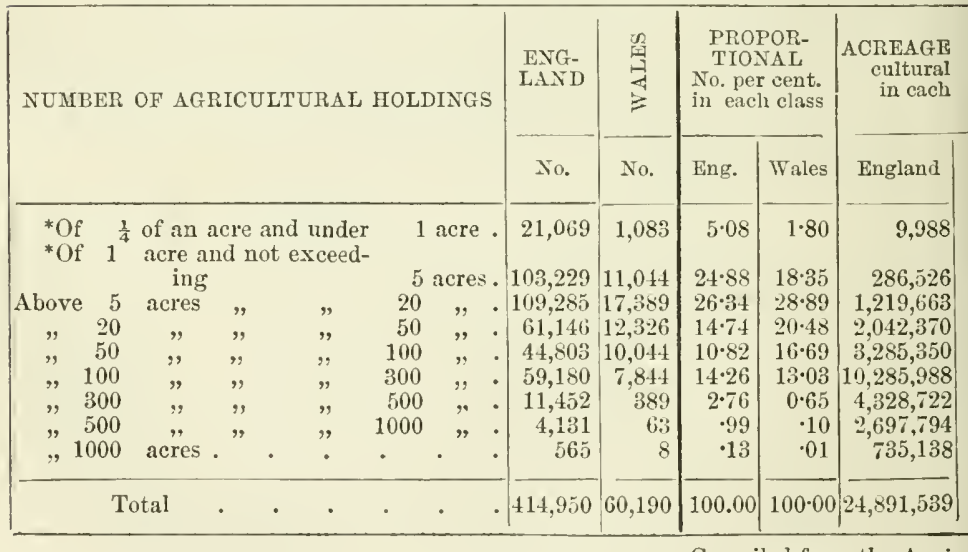

Compiled from the Agri-

* Probably many of these small holdings are also

1 See English Land and English Landlords, by the Hon. G. Brodrick, London, 18s1, 8vo; and The Great Landonners of Great Britain and Ireland, by John Bateman, 4th edition, London, 1883, 8vo. 
is far smaller. Thus 4,217 persons own half the land of England and Wales; and an amount exceeding the cultivated area of the country, or over 28 million acres, is the property of 38,000 persons.

English land laws, prior to 1882 , combined with social and economic causes to lessen the number and increase the size of landed properties. At the same time small farms decreased in number, as they were consolidated and thrown together to economise management and utilise machiners. The census for 1881 gives the number of tenant farmers at 223,943. But a fuller answer to the question-' How is the land occupied?' will be supplied by the following table. Though the average size of holdings in England and Wales is only 53 acres, yet 19 millions out of the 27 million cultivated acres, or rather more than on each Class of Agricultural Holding in England and Wales in 1885.

\begin{tabular}{|c|c|c|c|c|c|c|c|c|c|}
\hline \multirow{2}{*}{$\begin{array}{l}\text { of agri- } \\
\text { holling } \\
\text { class } \\
\text { Wales }\end{array}$} & \multicolumn{2}{|c|}{$\begin{array}{l}\text { A } \nabla \text { ERAGE } \\
\text { SIZE of } \\
\text { holding in } \\
\text { each class }\end{array}$} & \multicolumn{2}{|c|}{$\begin{array}{l}\text { No. of HORSES } \\
\text { in each class of } \\
\text { holding }\end{array}$} & \multicolumn{2}{|c|}{$\begin{array}{l}\text { No. of CATTLE } \\
\text { in each class of } \\
\text { ho!ding }\end{array}$} & \multicolumn{2}{|c|}{$\begin{array}{l}\text { No. of SHEEP } \\
\text { in each class of } \\
\text { holding }\end{array}$} & \multirow{2}{*}{ 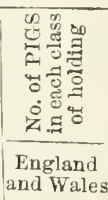 } \\
\hline & Eng. & Wales & England & Wales & England & Wales & England & Wales & \\
\hline 530 & $\frac{1}{2}$ & $\frac{1}{2}$ & - & - & - & - & - & - & - \\
\hline 34,532 & $2 \frac{3}{4}$ & $3 \frac{1}{4}$ & 21,259 & 1,837 & 85,910 & 13,955 & 85.730 & 21,947 & 155,048 \\
\hline 200,169 & $11 \frac{1}{3}$ & $11 \frac{4}{2}$ & 68,250 & 9.327 & 383,574 & 69,253 & 385,248 & 166,102 & 303,474 \\
\hline 420,482 & $33 \frac{1}{2}$ & 3.4 & 107.897 & 24,049 & 551,941 & 124,027 & $905, \pi 71$ & 489,602 & 298,724 \\
\hline 735,671 & $73 \frac{1}{4}$ & $73 \frac{1}{4}$ & 160,755 & 39,562 & 750,165 & 189,820 & $1,673,7: 57$ & 770.948 & 353,770 \\
\hline $1,233.374$ & $173 \frac{3}{4}$ & $157 \frac{4}{4}$ & 446,260 & 57,768 & $1,948,372$ & $2 \div 6,111$ & $6.469,35-$ & $1,100,444$ & 754,386 \\
\hline $143,6 \% 3$ & 378 & $369 \frac{1}{4}$ & 164,996 & 5,494 & 645,016 & 28,181 & $3,670,977$ & $1: 7,883$ & 225,010 \\
\hline 39,793 & 653 & $631 \frac{3}{4}$ & 90,041 & 1,082 & 301,224 & 5,527 & $2,784,094$ & 43,170 & 114,836 \\
\hline 10,373 & $1301 \frac{1}{4}$ & $1296 \frac{1}{2}$ & 19,410 & 242 & (j0,343 & 1,214 & 792,620 & 12,262 & 21,504 \\
\hline $2,818,547$ & 60 & $46 \frac{3}{3}$ & $1,078,868$ & 139,461 & $4,689,545$ & $708,09 \mathrm{i}$ & $16,766,854$ & $2,742,358$ & $2,226,752$ \\
\hline
\end{tabular}

cultural Returns of 1886 .

included in the field allotments (see Appendix XIV.).

two-thirds, are occupied in holdings ranging from 100 acres to upwards of 1,000 acres. The land thus owned 
and occupied was in 1881 tilled by 870,798 agricultural labourers. ${ }^{1}$

These conditions may be contrasted with the analysis drawn up by Gregory King, ${ }^{2}$ the Lancaster Herald, of the population of the country in 1688. King calculated the total number of families at $1,349,586$. Of this total number more than three-fourths were directly connected with agriculture, and three-fifths of the agriculturists enjoyed proprietary interests in the soil. The figures of early statisticians cannot be implicitly relied on; but whatever allowance is made for errors, the contrast is startling enough. Up to the commencement of the eighteenth century it was rare to see 'one only master grasp the whole domain.' 3

The most marked peculiarity of English land tenure is the small number of landlords, tenants, and labourers. At the present crisis this system has apparently collapsed, and failure is not unnaturally commonly attributed to its distinguishing feature. During the past fourteen years dis-

I In England and Wales, in the reign of Elizabeth, there were three million agriculturists to one million non-agriculturists. In the years of Protection 1801-41 the agriculturists were (1811) 35 per cent., (1821) 33 per cent., (1831) 28 per cent., (1841) 22 per cent. of the population. Now barely one-fifth of the population [26 millions, 1881] are engaged in agriculture. In France, in 1851, the industrial classes numbered 83 per cent. of the total population, and of these 56 per cent. were engaged in agriculture. In 1876 the industrial population had risen to 90 per cent, and 53 per cent. were agriculturists.

2 See Appendix VII. Census Returns, Table 1.

${ }^{3}$ In 1862 M. de Lavergne calculated that in France $37 \frac{1}{3}$ million acres were owned by 50,000 owners, whose estates averaged 750 acres; $37 \frac{1}{2}$ millions by 500,000 owners, whose estates averaged 75 acres; $37 \frac{1}{2}$ millions by $5,000,000$, who held properties averaging $7 \frac{1}{2}$ acres. In other words, one-third of the land was held by 50,000 owners, one-third by 500,000 , one-third b5 $5,000,000$. The statement is too neat to be absolutely true. But it is remarkably confirmed by the most recent estimates. See Edinburgh Review (Oct. 1887), 'Rural France.' 
tress has gradually increased in intensity, till it has ruined hundreds of landlords and tenant farmers. The stress of foreign competition falls with increasing force upon rents as the screw continues to tighten. With every turn of the screw the pressure becomes more intolerable for those landowners who are required to meet fixed charges from dwindling revenues. Their sufferings are none the less real because they are unexpressed. At a low estimate land has depreciated in letting value 35 per cent.; and a competent authority, Lord Derby, has computed the aggregate loss of the landlords at 300 millions sterling. The sufferings of tenant farmers rise more rapidly to the surface becanse the land is, as a rule, their only source of income. The last report of the Royal Agricultural Benevolent Institution affords significant proof of the reality of the distress. Upwards of 400 farmers, who had recently cultivated holdings varying from 100 to 1,000 acres, were applicants for relief. The same ruin now attacks the agricultural labourer. As the area of corm cultivation contracts, and land grows grass instead of grain, the economical transition means the destitution, if not the starvation, of thousands.

The facts are patent, but they do not necessarily result from any defect in the existing tenure or cultivation of the land. Their causes must be sought elsewhere. In the past, large landlords and large farmers won for England, directly or indirectly, the first place both in manufacture and agriculture. Nor is it only yesterday that they did good service to the State. Our system admits abuses and lacks elasticity; but capitalist landlords have proved the saviours, not the ruin, of farming. It is this class which to-day has saved England from the horrors which accompany distress in Ireland, and English land- 
lords have, voluntarily and by private bargain, offered reductions which law has there enforced. In this country the worst cultivated and most highly rented soil, and the most beggarly farm buildings, are found on the estates of small investors. If the numbers of this latter class were larger, distress wonld be proportionately increased, and their wretched dependents might as well hope to suck honey from flint as to obtain generous consideration of their distress. The blow has fallen upon the wealthy classes, not upon those who in igmorance resort to agrarian ontrage. Nor has the country failed to profit by the losses of individuals. Diminished rentals do not mean a corresponding increase in the wealth of foreign prodncers. The greater part of the 300 millions that landed proprietors have lost is distributed among the toiling millions of our great cities. Scherlule $D$ of the income tax, ${ }^{1}$ which includes all trades and professions, proves that within the past ten years the number of incomes ranging from 150l. to 500l. a year has grown 21 per cent. The public servants and salaried employés of private houses of business have increased 50 per cent. Estates paying probate duty below $5,000 l$. are more numerous; the capital of registered companies shows an increase of 90 per cent., but, while the number of shareholders has risen, the arerage amount of their holdings has fallen; the number of insurance policies has grown steadily, but the sums insured are smaller; the number of depositors in savings banks has increased, and the deposits per head are less; the insurance companies of the poor have enormously extended their business. These facts minister cold comfort to impoverished landlords and ruined tenants,

1 See presidential address of the Right Hon. G. J. Goschen before the Statistical Society, December 6, 1887. 
but, in striking the balance of profit and loss, they cannot be overlooked.

Under other systems of land tenure than our own, ruin is widely spread. Everywhere the pressure of foreign competition is severely felt, but in other countries it is accompanied by demands for relief which it is impossible to resist and mischievous to concede. Adrocates of a peasant proprietary belong, as a rule, to the party which is most deeply pledged to a Free Trade policy. Do they reflect that foreign experience shows their economical and agricultural theories to be opposed? The agricultural labourer has hitherto supported Free Trade; transform him into a small farmer, and you make him a Protectionist. From this, as well as from every other point of view, it is assuredly no time to hazard agrarian experiments, which can only succeed under exceptional combinations of favourable circumstances.

In many respects the existing relations of landlords, tenants, and agricultural labourers, might be advantageously modified. But the true lesson to be drawn from the small numbers directly interested in land is not that the existing system is to blame for the collapse, not that the three profits are necessarily doomed, but that the day has passed for legislation which favours a few producers at the expense of millions of consumers. In France one half, in England barely one fifth, of the total population are engaged in agriculture. The English landed interests waste their strength if they struggle for relief in the form of Protection, or the reduction of the tithe rent-charge. What chance have 38,000 landlords and 224,000 farmers of persuading twenty millions to pay $6 d$. for a loaf of bread which they can now purchase for $4 \frac{1}{2} d$.? For every one 
who says bread is too cheap there are a hundred who find it too dear. Or what prospect has this same handful of persons of appropriating to their own use funds the reversion of which belongs, under remote and doubtful, but not impossible, contingencies, to the nation as a whole? 


\section{CHAPTER XV. \\ PROTECTION AND TITHE RENT-CHARGE.}

Historically ${ }^{1}$ Protection is associated with a period of prolonged and unprecedented distress, with agricultural gambling and reckless speculation in land, with bankruptcy and insolvency of farmers, with the degradation and pauperism of agricultural labourers, with high prices and extravagant poor-rates, with incendiarism and starvation, with hunger made and perpetuated by law in the interests of a single industry. This was the price which the nation paid for artificial rents and artificial prices.

There once lived a philosopher, who, seeing that he had scratched out both his eyes in a quickset hedge, determined

To jump into a bramble bush

And scratch them in again.

His example is urged by Protectionists, not only upon the nursery, but upon the nation generally.

A black mark is set against Protection in the memory of consumers in this country; the system itself is also discredited by comparative failure on the Continent. It is established in France and Germany $;^{2}$ but import duties do not enable farmers to grow wheat at a profit. In Germany, as has been said, farmers have only gained by

1 See Chapter IX.

2 See Appendix XII., Peturn of prices of wheat in France, Belgium, and Prassia. 
Protection, because the Government applies the revenue which it yields to the reduction of local burdens on farming industries. From France comes the same tale. France had always preserved an import duty of 60 centimes the quintal on foreign wheat, and of $1 \mathrm{fr} .20 \mathrm{c}$. on foreign fiour. In December, 1884, the Chamber of Deputies decided to propose import duties not only on wheat and flour, but on oats, rye, barley, and malt, which had been hitherto imported free. In spite of strong protests, the policy of Protection was finally adopted in 1885. The duty on foreign wheat was fixed at $5 s .3 d$. the quarter, and 25 francs per head was charged on all foreign cattle. M. Tirard, the present Premier, was then Minister of Finance, and the Ministry promised increased duties if agriculture did not improve. The pledge has been kept; the duty on foreign wheat was raised to $8 s .9 d$. in 1887 , and other duties in proportion. It may be added that France annually imports eight million quarters of grain. The recently published reports by English Consuls at French ports show that $5 s .3 d$. per quarter was an inadequate duty. At Bordeaux duties on foreign cattle have not raised the prices of live stock, which, within the last two years, fell from 6 to 8 per cent., and the same remark applies to cereals. Near La Rochelle corn does not pay, live stock sells cheaper at each successive fair, markets are overstocked with fruit and vegetables. Peasant owners must either sell their land or be supported by the nation. They will undoubtedly choose the latter alternative, and the next elections will be decided on the cry for increased protection. In the Brest district rents are unpunctually paid, and peasant proprietors are falling hopelessly into debt. Round Harre import duties have not raised the price of cereals. 
In the neighbourhood of Boulogne and Dunkirk prices both of corn and cattle have fallen. On the other hand, the important grain trade of Marseilles is suffering severely from the Protectionist policy. The obvious result of Protection is to decrease both exports and imports of agricultural produce; but the example of France shows that import duties have not raised the prices of wheat and beef, which are lower than when the duties were first imposed. The fault is that the duty is not large enough, and it may be confidently anticipated that it will be shortly raised from $8 s .9 d$. to at least $12 s$. a quarter. ${ }^{1}$

The result of English and foreign experience on the subject of Protection is universally this. Import duties ruin the grain trade of seaport towns, but they do not necessarily raise the home price of wheat, because they stimulate over-production at home. In England from 1820-48, in France and Germany from 1885 to 1887, wheat did not rise, but rather fell, in consequence of the exclusion of foreign competition. Farmers cut their own throats by increasing their breadths of corn cultivation. Hence, if protection is advocated as a remedy for low prices, it fails to produce the desired result, and the cry is raised for higher duties. It is probable that nothing short of a duty of $20 \mathrm{~s}$. a quarter would raise bome prices to the point at which wheat would become profitable; and if bread rose to $6 \frac{1}{2} d$., this price means an income tax of at least $1 \mathrm{~s}$. a week on the wages of labour.

Everyone now regrets that Mr. Gladstone, in 1869, took off the $1 s$. duty on corn, which did not keep out a single quarter of wheat or raise the price of bread a

1 In Germany the demand of agriculturists for increased Protection seriously embarrasses the political action of the Government. Austria and Hungary export quantities of wheat and flour to Germany, which the agrarian party desire to exclude by doubling the existing duty. 
farthing; in the seventeen jears that have since elapsed, this economic pedantry has cost the nation nearly twelve million pounds; and once taken off it cannot be put on again. It is not denied that import duties, if they are high enough, would benefit farmers, or that the stimulus which they would give to arable farming would indirectly prove advantageous to agricultural labourers. But wheat cannot, it is said, be grown at a profit moler $40 \mathrm{~s}$. Is an import duty of $20 \mathrm{~s}$. likely to be obtained, or, if granted, is it large enough to succeed? Both questions: must be answered in the negative. Fair traders are not likely to embarrass the question of taxing manufactured articles with the unpopular demand for the taxation of raw necessaries of life. Bread is the exclusive food of thousands; its cheapness cannot be diminished in the face of trade depression; it is the very last article which any Government can venture to tax, for the charge falls on the very poor. Agriculturists will only prove the catspaws of manufacturers if they swell the cry for Fair Trade. It is useless to ask for what, in all human probability, can never be granted. The consumers, and not the producers, of bread and meat now govern public opinion. The landed interests would, it is submitted, be wiser to concentrate all their strength upon obtaining pecuniary relief from foreign competition, not by raising the price of bread and meat, but by shifting a portion of the load of taxation which burdens real property to the shoulders of personalty. The effect of an import duty is to counterbalance existing taxes upon land; if those taxes themselves are lightened, the same object is effected in a less objectionable manner.

Tithe rent-charge difficulties are less obviously, but not less vitally, affected by the numerical inferiority of 
the landed interests. Fifty years ago agricultural depression raised an agitation against tithes. It was said, with great force, that tithes upon produce discouraged and retarded agricultural progress at a moment when the rapid growth of population rendered it necessary to develope to the full all the resources of the soil. One among many of its evil effects was to prevent the ploughing up of pasture land. A Parliament of landlords listened favourably to the cry. The gross tenth of the annual produce of titheable land on the average, taken from 1829 to 1835 , was $6,756,105 l$. But the sum at which it was commuted was $4,053,663 l$. In other words, 40 per cent. of the gross tenth went at once into the pockets of the landlords. Besides this, they also received all that portion of the increased value of the produce of the land which, prior to 1836 , would have fallen to the Church, and which Sir J. Caird, in 1877, estimated, at two million pounds a year. Tithe rent-charge stood still while rentals rose; it was in 1836 as 4 millions to 33 millions (or more probably 28 millions); in 1877 it was $4 \frac{1}{2}$ millions to 51 millions. Thus the gain which landowners received from the Tithe Commutation Act of 1836 must be measured by many millions.

In 1887, as in 1836, under the pressure of agricultural distress, the cry against tithe rent-charge is renewed. But times and tempers are entirely changed. Landed interests no longer rule supreme in Parliament, and it cannot now be said that the charge retards and discourages agricultural progress, for it falls on the land and not on the produce. The agitation takes the shape of a demand for its revaluation, that is to say, its reduction. It is said that tithe rent-charge has become a disproportionate burden, and must be readjusted, or, 
without circumlocution, must, be cut down to relieve landlords and tenants. In the first place, the Act of 1836 was designed to fix proportions not between rent-charges and the value of the land out of which they issued, but between rent-charges and their purchasing power in coin, to commute tithe of produce in kind for variable money payments charged upon the land, and maintain existing relations between values of titheable produce and prices of living. So far as the Act has failed, it has failed because it has not guarded the interests of tithe-owners. In the second place, even if the real issue was whether the tithe rent-charge is disproportionate to the value of land and ought to be readjusted, the factors in the question are the relations which the charge bears to the rentals of 1829-35 and 1887, not those which it bore to the rentals of 1870-80. Those who bought land fifteen years ago purchased unprofitable bargains, and undoubtedly the tithe rent-charge has not decreased proportionately to their rentals. But this fact, though it may elicit sympathy, is beside the mark. The question is-does the tithe rentcharge at $3 \frac{1}{2}$ millions bear a relation to the rental of 1887 disproportionate to that which it bore at four millions to the rental of 1836 ? 'The answer can only be in the negative. Assume that rentals in 1887 have fallen to the figure at which they stood in 1836, and no one can pretend that they have fallen below twenty-eight millions, there still remains a considerable margin in favour of the tithe-owner. ${ }^{1}$

1 Sir James Caird takes 33 millions as the amount of rental in 1836. If this figure had been arrived at by Sir James himself, it would command acceptance upon lis authority. But it appears that. Sir James adcpted it from the Encyclopadia Britannica (Letter to the Times, July 22, 1879), and the estimate is, for two reasons, probably extravagant. The gross annual value of the produce of the land in 1829-35 


\section{Even supposing landowners could prove their case} against the tithe rent-charge, a glance at the nature of the charge shows how hopeless is their expectation that the nation will submit to its reduction. Tithes form part

averaged 101,000,000l. If 33 millions was at that time the rental, the produce only amounts to three rents. Four rents is a more reasonable allowance, and this wonld bring the rental of 1836 to 25 millions. Again, Schedule B of the Income Tax, 1814-15, gives the rental of England and Wales at $34,028,655 l$. But these are the war rentals. There was no Income Tax from 1816 to 1842 ; but the evidence given before Sir James Graham's Select Committee on Agriculture in 1833 shows that rents were undergoing a reduction of from 20 to 30 per cent. They continued to fall for the next five Jears. If in 1836 the rental was 25 millions, it would show a reduction of 25 per cent.; 33 millions only allows a reduction of 3 per cent., which is contrary to the evidence before the Select Committee. Lastly, in 1845, a careful inquiry into the valuation of land for taxing purposes shows that it had not even then materially increased in value since 1815. (See Parl. Papers, 1846, vol. xl. page 14). For these reasons it is impossible to "put the rental of 1836 higher than $2 \mathrm{~s}$ millions. The tithe rentcharge has been reduced $12 \frac{1}{2}$ per cent. since 1836 . Therefore, unless landlords are prepared to prove that their rentals amount in 1887 to only $24 \frac{1}{2}$ millions, they cannot assert that the relation which the rent-charge bears to rents in 1887 is disproportionate to that which it bore to rent in 1836. It is perhaps worth while to notice that a pamphleteer in 1767 , who adrocates the commutation of tithe, states that it then amounted to between a fourth and a third of the rent. He puts the rental of England and Wales at 16 millions, and the tithe, at its lowest computation, at $4 \frac{1}{2}$ millions. (Political Speculutions on the Dearness of Provisions, Part II., 1767.) Another writer (Three Letter's to a Nember of the Houso of Commons, from a Country Farmer, 1766) demands the abolition of tithes in kind, and asks that the existing charge should be commuted at a "portion of the fair rent-say an 8th, a 7 th, a 6th, or a 5th.' This advanced reformer never contemplated that for a considerable portion of the last half-century the tithe would not amount to a tenth of the rent. Arthur Young calculates tithe at 3s. $6 d$. an acre; to this he adds a further sum for the gathering. He estimates the rental of the land of England at 22,400,000l. and the tithe at 7,000,000l. (Eastern Counties: London, 1771, vol. iv. p. 459.) Yet landlords and farmers complain that they have lost by the Tithe Commutation Act of 1836. See also 'The Tithe Qnestion,'Edinburgh Revien, January, 1888. 
of a fund vested in the clergy to promote the spiritual interests of the nation, and are, as the law now stands, inalienable, so long as religion is recognised to be a vital element in the national welfare. But subject to this life-interest of the Church, the nation claims the revenue in reversion. It is the duty of the State to preserve intact the corpus of the property. Upon this point Church and State are united; the present interests of the first, the prospectively possible interests of the second are identical. Sections of the community desire to divert the fund to secular purposes; but though those who seek to secularise the charge are actuated by antagonistic motives, they are agreed that the fund shall not be reduced.

Donbtless the landed interests might benefit by the appropriation of tithes to the relief of local taxation. But so far as landlords and tenants have joined in the antitithe agitation, they have demanded its reduction, not its secularisation. They therefore ask the very thing which the clergy, the secularists, and the Nonconformists, and incleed the whole body of the nation, are interested in refusing. No class benefit can be obtained except at the expense of the conmunity; no relief can be extended to landlords without a corresponding diminution of the fund now dedicated to religious purposes, but under certain contingencies, available for education or similar objects. It is the obvious interest both of the Church and the State that whatever profits are derived from dealing with the charge should be secured for national purposes. If the four millions of money alienated from the Church at the Reformation and in 1836 were still available for national objects, the sting would be gone from the present agitation against tithes. Till now each successive change has impoverished the clergy and enriched the 
landlords; but while the Church is weakened, no portion of the sum has hitherto been set aside to meet the cry that there are other national purposes besides those of religion. Is this fatal course to be again pursued at the present crisis? Is it at all likely that a handful of the community can repeat their financial triumphs at the Reformation and in 1836 , in opposition not only to the life interests of the clergy but the reversionary interests of the nation? If landlords or farmers agitate against tithe in the hope that it will be reduced, they will be inevitably disappointed. They are in fact only the stalking-horses of those who desire to appropriate the funds to secular objects.

Some change in the charge is doubtless imminent. The first proposal leaves the incidence where it now rests, but alters the calculation. Thus the septennial averages give the tithe-owner for every $100 l$. of tithe rent-charge 87l. 8s. $10 d$; the prices of the year 1886 would have given him only $75 l .1 s .5 \frac{1}{2} d$. If the charge were computed in 1888 according to the preceding six years, and that for 1889 according to a quinquennial average, the charge of 1893 , if the length of the averages were thus annually reduced, would be the prices of 1892 . But there is no reason to suppose that so slight a change would reconcile tenants to the continuance of their liability; and if the concession is only the first of a series, there is absolutely no ground for thus mulcting the clergy.

A second proposal changes the incidence and does not alter the calculation. It makes tithe rent-charge altogether a landlord's outgoing, and insists that all land shall be rented tithe free. But the proposed change hardly pretends to be final; the spiritual interests of the nation will still be prejudiced, though the clergyman becomes the tithe proc- 
tor of the landlord instead of the evicting bailiff of the tenant farmer'; and, lastly, if 5 per cent. compensation is granted to the landlords by the legislature, the national reversioner can never again claim the whole of the tithe rent-charge. It irrevocably surrenders to individuals, for doubtful benefits, 5 per cent. of a property which belongs to the whole body of the clergy and laity.

These considerations seem fatal to any legislation which only proposes either to continue the present liability of occupiers or to render the charge an owner's outgoing. The Government Bill of 1887 erred, as it seems, in not going far enough. So long as the principle of voluntary redemption by landlords is adopted, the scheme must be necessarily impaled on the horns of a dilemma. If the terms are made easy, the scheme may work, but it works at the cost of clerical and national interests. If the terms are disadvantageous, clerical and national interests are preserved, but the scheme is stillborn and a dead letter. The terms offered in the recent Bill rightiy protected religious life tenancies and national reversions. But the result was that only trustees, colleges, and other bodies, whose powers of investment are limited, could have profitably redeemed the charge. Apart from a landlord's unwillingness to store all his eggs in a rickety basket, the proffered terms would have tempted no one who could command more than 3 per cent. for his money. So long, also, as agitation can be brought to bear upon a small body of tithe-owners, tithe-payers will hold back for better terms of redemption. Convince agitators that the interest of the tithe-owner and the nation is in fact one, and you convince them of the hopelessness of delay. The only principle upon which a scheme of redemption can be made immediately operative, without emriching individuals from 
the corpus of a property which belongs to the clergy and the State, is to show that the life-tenant and the reversioner are the parties with whom the bargain must be struck.

Redemption, therefore, appears to be the final solution of the difficulty.

The first step towards the extinction of the charge is for the State to undertake its collection, and compel tithepaying tenants to deduct the charge from the rent. Assume, by way of illustration only, that the State guarantees to the clergy a net 60 per cent. of the 100l. charge regularly paid, free of rates, taxes, and costs of collection. At present values this would leave the State a margin of $27 \frac{1}{2}$ per cent., out of which to pay the necessary outgoings. In the hands of the clergy there must be deducted from the gross value of the tithe, besides 15 per cent. for rates and taxes, 10 per cent. for arrears, remissions, abatements, and costs of collection. In the hands of the State this last percentage would be reduced to $2 \frac{1}{2}$ per cent., and thus the State would have 10 per cent. in hand to meet further falls in the averages, and compensate, in special cases, the losses incurred by landlords pending new arrangements with their tenants, or by the clergy through diminution of income. But the margin would be rapidly freed from liability in respect of these two last payments. Thus protected, the State could well afford to wait a turn in the tide, and escape a ruinous sale in a falling market.

All schemes of redemption, whether compulsory or voluntary, proceed on the basis of State co-operation. The State raises a loan at 3 per cent. and lends at 5 per cent. The difference at compound interest pays off principal and interest within a fixed period. The amount of the State loan, the extent of the advance to landlords, the 
rate of interest charged, are mainly determined by the rate of years' purchase at which the charge is capitalised. It is the interest of the State to demand thirty years' purchase, of the landlord to offer fifteen. Between the two rates lie the possible compromises. But the basis upon which the charge is generally valued for redemption seems false in principle. A uniform rate of purchase based upon the gross value of the charge, subject to the dednction of the average necessary outgoings, would press hardly on individuals. Rates vary in every parish. Thus in $A$ the rates are $7 s .6 d$, in $\mathrm{B} 5 s$. , in $\mathrm{C} 2 s .6 d$. The average outgoing in these three parishes is 5s. in the pound, and this deducted from the gross valne of a hundred pound tithe rent-charge leaves $75 \mathrm{l}$. as the sum to be redeemed. Assume, for the sake of illustration only, that twenty years' purchase is a fair rate at which to capitalise the charge, and in A, B, and $\mathrm{C}$ the charge is redeemed for the same capitalised sum of $1,500 l$. But observe the different values of the purchase. The withdrawal of the tithe rent-charge from the amount of rateable property in each parish necessitates a readjustment of the assessment upon the remaining property. Practically speaking, landowners will be additionally burdened by the amount now borne by the tithe rentcharge. Therefore, in A parish the annual value of the purchased charge is $62 l$. $10 \mathrm{~s}$, in $\mathrm{B} 75 \mathrm{l}$, in $\mathrm{C} 87 l .10 \mathrm{~s}$. In other words, the landowner in A buys a very bad, in B a fair, in $\mathrm{C}$ a very good bargain. The most equitable method would be to calculate not the average but the actual outgoings, and to purchase the charge at its net value. Under these circumstances the charge would be redeemed in $\mathrm{A}$ at 1,250l., in $\mathrm{B}$ at 1,500l., in $\mathrm{C}$ at $1,750 l .{ }^{1}$

1 If the outgoings are similarly capitalised at twenty years' purchase, it will seem that the sum in each parish is actually the same. Thus in 
This calculation shows the important bearing of rates upon the question of tithe redemption, and indicates the direction in which, if anywhere, landlords and tenants must look to gain by the State collection of the tithe rent-charge. Redemption may be compulsory and immediate, in which case landlords would borrow from the State at 5 per cent. the sum required for redemption, and in less than fifty years would have paid off principal and interest and extinguished the charge. But the terms would be necessarily governed by the miserable state of the present market. Church and State must be content not only to make a wretched bargain, but to see the value of the property rise for the benefit of individuals rather than of the community. Suppose, on the other hand, as has been suggested throughout, that the State undertakes the collection of the tithe, and, protected against possible loss by a considerable margin, waits for better times, and that redemption is voluntary and gradual. What then? It is in the highest degree improbable that land, which is limited in quantity, should permanently lose its value in the midst of a growing population, and the selling value of the rent-charge will benefit by any rise in the value of the property out of which it issues. If, again, agricultural depression should prove in some degree a question of currency, a readjustment of our financial conditions by depreciation of gold or appreciation of silver would restore agricultural industries to health and advance the value of the tithe. If, again, the country were to embark on a policy of Protection, the value of the charge would rise immediately, if not permanently. If, again, as the populations of foreign countries

$\mathrm{A}, \mathrm{B}$ and $\mathrm{C}$, respectively, the capitalised outgoings are $750 l$., $500 \mathrm{l}$., and $250 l$., and the respective prices paid are in $A 1,250 l+750 l .=2,000 l$; in B $1,500 l_{.}+500 l_{.}=2,000 l_{\text {. }}$ in C $1,750 l_{\text {. }}+250 l_{.}=2,000 l$. 
increase, the surplus production which now floods our markets were consumed in the land of its growth, the tithe rent-charge would once more approach par value. Even its present value is unduly depreciated by the alleged insecurity of the tithe-owner's tenure; it is worth far more if not only the life tenant but the reversioner guarantee the title. Even to those who hold no optimistic views of the immediate future of farming, the sale of property of the nature of the tithe rent-charge, even though a purchaser is found by compulsion, appears little short of financial suicide. If these improvements in the value of the charge appear too distant or too problematical, it cannot be disputed that the readjustment of local burdens is a measure of the immediate future. Local taxation is the weight which really crushes English farming; relief has been long promised and long deferred; it cannot now be long postponed. But the immediate result of any readjustment of the load will be to enhance the net value of the rent-charge. If the State holds the charge, the benefit of this certain rise will be secured; the national fund, and not any private individual, will benefit; and, until religion is voted to be noxious or obsolete, the increased money will continue as now to be sacred to religious trusts. At the same time, so long as the State collects the fund, it can afford to be generous with the additional value its own action creates. The larger the reduction of local rates, the greater the gain upon the tithe rent-charge, and the larger the sum which might be devoted to such objects as the establishment of a system of land transfer by registration, the equipment of an efficient State department of agriculture, or scientific and technical education in farming. 


\section{CHAPTER XVI.}

\section{LEGISLATIVE AID ; LAND LAWS, LAND TRANSFER,} EDUCATION, RAILWAY RATES.

If the nationalisation of land is rejected as an impossible plan; if rural society is not to be reconstructed on the ruins of the landlord system; if farmers must combat foreign competition with no other weapons than those of resolute, capable men ; if Protection, condemned by history and discredited by recent failure, is placed beyond the reach of agriculturists; if a reduction of tithes is scarcely less hopeless because the reversion of the fund belongs to the community at large-what, it may be asked, becomes of the Land Question? It is reduced to its practical meaning; and that practical meaning varies, apart from peasant proprietors, Protection, and abolition of tithes, with the respective needs of owners, occupiers, and cultivators. Landlords may possibly hint that production is hindered because farmers have adopted extravagant standards of living, and neglect their business. Farmers, perhaps, blame landlords, and attribute depression to high rents, restrictions upon cropping, land laws, and want of security for tenants' improvements. Both will probably agree that the seasons have been adverse, that land is exorbitantly taxed, that railway rates favour foreign producers, that hired labour is scarce, dear, and bad. The agricultural labourer has his own special grievances. He complains that there is no rung in the social ladder on which he can 
place his foot; that his wages do not permit him to save; that, though unable to supplement them from other sources, he depends entirely upon them; that it matters little whether he scamps his work or does it honestly, whether he attempts to save or calls for another pot of beer, for the workhouse is his inevitable end. The general pnblic may, perhaps, include among these and other causes of depression, the sense of insecurity which scares away capital from the land; dimly comprehended currency questions, to which, like the Gulf Stream, all that is inexplicable may be attributed; the want of elasticity and variety in farming practices; the lack of sufficient capital, adequate knowledge, energy, and business enterprise, among both landlords and farmers.

These are the practical meanings of the Land Question. Some of them can only be adequately discussed by experienced agriculturists, and upon such it may appear presumptuous to touch. But, without any desire to teach farmers their business, it is impossible not to observe in every country district many points in wlich the general standard falls hopelessly below the practice of the few. Many of the causes of agricultural distress can be controlled by farmers themselves; others, like the seasons, defy human calculation. Some, on the other hand, can only be removed by legislative action.

This chapter will be confined to this latter class, and to such snbjects as the reform of the land laws, the provision for scientific agricultural education, the equipment of a ministerial department of Agriculture, the revision of railway rates.

Insecurity lies at the root of the present conditions of agriculture. Foreign competition, following upon disastrous seasons, produced the present collapse: it has been 
perpetuated by want of confidence. So long as wild proposals for compulsory redistribution of property received the support of prominent politicians, no landlord would expend money on improvements, no capitalist, large or small, wonld invest in the purchase of land, no tenant would accept a lease, no labourer wouid put his heart into his work. While the intentions of the Legislature remained dubious and threatening, land continued to be unsaleable and half-farmed. Behind all legislative changes lurked the ominous question of confiscation. Land may be treated as private property, held so as not to prejudice the public welfare, but not to be taken from owners without fair compensation; or it may be distinguished from private property, and the principles which gnard private property held inapplicable to land. On which line was land legislation to proceed? Wild talk about Stateownership, ransom, and natural rights, societies to nationalise the land, heroic remedies of illogical half-disciples of Mr. George might be in themselves of little importance. But when the air was filled with vague threats, the attitude of ministers remained studionsly nentral. Agitators complained of conditions which they themselves rendered chronic. Meanwhile the continned insecurity was rapidly producing results which threatened the subversion of rural society. Fortunately the example has been given that a patriotic fusion of political parties for the promotion of national interests is yet possible in party government. That restoration of confidence, which is the indispensable preliminary to agricultural revival, seems already to have begun, and to bear fruit in renewed energy.

Arguments nrged against the artificial creation of a peasant proprietary scarcely apply to their natural growth. Economically States gain more by agricultural factories 
than by small farms conducted as domestic industries. Socially the advantages of a class of peasant owners are indisputably great. The rural economy of the nation would benefit by the diffusion of land ownership, and farming offers no exception to the rule that two strings to the bow are better than one. If legislation is only invoked to remove artificial aids to the aggregation of large estates, the process will not foster that sense of insecurity which has paralysed the energies of landlords, and rendered chronic the enfeebled state of agriculture. Already signs appear of a tendency towards the multiplication of small tenant-farmers, if not of small orners. Small holdings obstructed progress so long as capital was required for the reclamation, enclosure, or drainage of land. But at the present day this argument loses much of its force. So again, while England depended for grain on home supplies, corn could be produced more economically on large farms. Now, when prices render its home production unremunerative, and foreign supplies are adequate to our wants, another argument for large farms is at least modified. Small farmers, content with small profits, depending on gardens, livestock, and dairies, commanding the umpaid labour of their own families, may make both ends meet, where larger capitalists go through the Court. If agriculture is tending in this direction, legislation must remove all hindrances to its natural course; landlords are sufficiently alive to their own interests to do the rest. The risk of forcing streams into artificial channels is increased by the arguments which have been urged, from an economic point of view, against the creation in this country of peasant proprietors. In the nncertainty of their success under the changed conditions of modern agriculture, it is madness for the State to dictate, by positive legislation, the direction of their advance. 
Many advantages undeniably flow from an increase in the number of proprietors of the soil, and where men do not become owners of small tenant farmers. But the creation of either class must remain a matter of individual enterprise. No State can afford costly experiments on a large scale, the success of which is doubtful.

Whether land is farmed ligh or low, by large or small farmer's, by peasant owners or capitalist tenants, it is socially and politically expedient that legislation should remove all artificial obstacles to the acquisition of small interests in land, or the development of high farming, which hitherto has never obtained a fair chance of displaying its capabilities. In either case the preliminaries are the same, a reform of the land laws, and a scientific and practical agricultural education.

The object of land law reform is twofold : the extinction of all hindrances to the full development of landed property, and the simplification of the transfer of land. To the first head belong such changes as the abolition of primogeniture and entail, and other changes which assimilate the laws of real and personal property. The declaration of the spirit of the law in favour of primogeniture appears, from the rarity of intestacy, to be a matter of slight importance. It is different with the other objects of land law reform. Before 1882 the land was held by a series of life tenants, each of whom in turn, so soon as they arrived at the age of so-called discretion, deprived themselves irrevocably of the free use of their estates. Thus life tenants were hampered with restrictions upon the development of their property, burdened with encumbrances, unable and unwilling to spend money on improvements. Lord Cairns's Settled Land Act made one gigantic stride in the right direction; impending legislation makes a second. 
Lord Halsbury's Bill, which will probably be reintroduced in the ensuing session, abolishes primogeniture and entail, but leaves untouched the power of testamentary disposition and of settlement. Taken in conjunction with Lord Cairns's Act, it relegates this side of land law reform to the limbo of obsolete grievances. Short of abolishing settlements altogether, it is difficult to see what additional freedom can be given to life tenants, unless, indeed, the power of creating life estates were limited to their creation in favour of children.

The second object of land law reform is to cheapen and facilitate the transfer of real property. Examinations of title are costly, tedions, and insecure: mountainons piles of unintelligible deeds, lengtlyy abstracts, heary law charges, and blistered titles characterise the existing system. It is said that the transfer of land cannot be cheapened or facilitated until it is freed from the complicated titles which settlements enconrage. The heroic remedy is therefore suggested to abolish settlements. If this course were adopted, indefeasible titles might be safely conferred by registration; withont this preliminary step, it is donbtless hazardons to guarantee registered possessory titles, even when, after due notice, thes remain unchallenged. This risk is less than lawyers make it appear. Legal conservatism may go too far. National interests would suffer from the loss of the power to prevent property accumulated by thrift from being squandered by extravagance. But if lawyers insist too strongly on the injustice of guaranteeing titles by registration, they peril the existence of settlements. A cheap and easy method of transfer is imperatively demanded. Among European nations the want is almost universally supplied; England is nearly the solitary exception. It may be impossible to combine 
land registration with secret conveyances and equitable mortgages, though the example of Australia proves the contrary; but there can be no valid reason why all conveyances should not be pnblic, or why informal mortgages should continue to exist. Unless titles are guaranteed by registration, registries become merely records of dealing with land, or additional epitomes of titles which lawyers are compelled to search. The mere establishment of a registry of deeds is a retrogression. What is required is a public and compulsory system of land registration, based upon careful cadastration, which shall pass the estate by the official act of the registrar. Some cases of hardship may admittedly occur in the first establishment of a land registry; yet the number and importance of these are exaggerated. Adequate means for introducing the new system are already provided by the register of the Land Tax Commission. The intricacy, expenses, insecurity, and delays of the existing mode of land transfer necessarily check the circulation of land, and lessen its value as the basis of credit. To small capitalists, the class which all land reformers desire to encourage, the cost of conveyance presents a formidable obstacle. Deeds are not only expensive, but to ignorant persons terrible. Small investors cannot afford the luxury, and, if they could, they shrink from the terrors of the unknown. The market might be glutted with land, but till the present system of examination of title and execution of deeds and conveyances is abolished, purchasers of the class of peasant proprietors cannot, and will not, come forward. The Settled Land Act of 1882 gave tenants for life powers to sell, but it conld not make land saleable. The difficulty is, not how to increase the quantity of land for sale, but how to double the number of purchasers. There is plenty of land in the 
market, but there are few buyers, because, among other reasons, land is an inconvenient form of property, awkward to deal with, and therefore tempting only to the rich. The result of such a system is that the majority of persons in this country have no sympathy with ownership of land, and neither feel respect for, nor desire to secure, the sacredness of real property.

The difficulties of introducing land transfer by means of registration are undonbtedly great. They are courageously met in Lord Halsbury's Land Transfer Bill of 1887. The Lord Chancellor proposes to render transfer by registration universal, to bring estates gradually under the Act through the agencies of local registries in districts from time to time declared, to invalidate all dealings with land by sales, mortgages, conveyances, or settlements, except through the machinery of registration, and to establish a guarantee fund for the compensation of aggrieved purchasers. The details of the Bill will be better understood if the proposal is compared, both in its introduction and its working, with systems of land transfer already in operation.

In the Australian colonies the system has been in force since it was introduced into South Australia thirty years ago by Sir R. Torrens. Upon the Torrens Act Lord Westbury and Lord Cairns based their legislation of 1862 and 1875, and on it the Prussian legislation of 1872 is founded. All land alienated by the Crown subsequently to 1858 was brought under the Act compulsorily, and the title of the owner was the Registry; land previously alienated was registered voluntarily. In the latter case, the applicant submits his title to examiners, who report to the registrar upon the clearness of the title and of the description of the parcels. Notices of the application 
are then issued, and if no objection is alleged within a certain period, duplicate certificates of title are drawn up, one of which is placed on the Registry, the other lianded to the owner. Applicants in undisturbed possession, or enjoying good holding titles, are registered. It is not necessary to show such absolute titles as will satisfy punctilions conveyancers, or can be enforced upon unwilling purchasers. Registrars do not demand strict proof, but admit qualified, possessory, and prima fucie claims. Error is guarded against by a guarantee fund. Cases of fraud or mistake hardly ever occur; in 999 cases ont of 1,000 , the title proves sufficient. If the registered orrner mortgages his land, he retains his certificate of ownership, but it is endorsed with the charge. Thus, while he cannot deceive second mortgagees, he retains the power of additionally charging his land. He can, if he likes, effect equitable mortgages by lodging his certificate of ownership with a creditor, who issues a caveat to the registrar, forbidding him to register any further dealing with the estate till some named period has expired after notice is given. The land is then marked in the Registry with a red cross; and the notice given to equitable mortgagees of the intention to effect additional charges enables them to secure priority. Both settlement and entails exist in Australia, and are effected by registration. In these cases the life-owner is registered as such, and the folio of absolute ownership is closed. Each owner who places himself on the register, or succeeds to land by inheritance or by will, subscribes $\frac{1}{2} d$. in the pound to a Guarantee Fund, out of which, in cases of fraud or error, aggrieved purchasers or rightful owners are indemnified. No money is paid out of the fund to the first registered owner; but it enables him to offer the estate to purchasers 
with the guarantee behind his back. Purchasers are not entitled to compensation until they have exhausted all possible remedies against fraudulent vendors. In cases of error, the rightful owner is compensated, not placed in possession. This system has been in operation for many years in the Australian colonies. $U p$ to 1886 only four titles have been cancelled, and only 2,000l. has been paid away in compensation. The aggregate amount of the Guarantee Fund is over 200,000l.

The Prussian system ${ }^{1}$ was adopted in May, 1872, and has since been applied in many of the German States. It proceeds on the same lines as the Torrens Act. In Prussia registries of deeds in which all mortgages were registered existed in every market town, and also a cadastral survey in which estates were defined. On these bases the law worked. Full titles of ownership of land

1 The subject is likely to prove of such importance that some of the best and most recent authorities are qnoted below for the benefit of those who care to pursue it further.

(a) For the introduction of the system.

(i.) Lehrbuch des preuss. Privatrechts, von Heinrich Dernberg, 3. Aufl. vol. i. p. 450 et seqq., sections 190-199.

(ii.) Handbuch des deutschen Privatrechts, von Otto Stobbe, vol. ii., sections $94-95$.

(b) For the system itsclf.

(i.) Die preussischen Grundbuch- und Hypotheken-Gesetze, von H. Werner (1873) (quoted by Mr. Brickdale).

(ii.) Das prenssische Grundbuch-Recht, von H. Bahlmann (quoted by MI. Scott).

(iii.) Reports on Saxe-Coburg Land System and Prussian Land Transfer Laws, by Mr. Scott of the British Embassy at Berlin. Parliamentary Papers, Commercial Papers, part i. 1882, and Report, 1887.

(iv.) Annuaire de la législation étrangère, Paris, 1873. Art. par M. Paul Gide.

(v.) Law Quarterly Review, vol. iv. p. 63 et seqq. Jan. 1888. Article by Mr. C. F. Brickdale. 
can only be acquired by registration; all charges on real property are invalid, until they are registered in the 'Grundbuch,' or Land Register, of the commune, arrondissement, or other territorial unit. No property acquired by will or inheritance can be alienated or charged until the new owner registers his title, and for this purpose he produces an official certificate of probate. Persons in possession of land when the Act came into operation were required to register their titles on the 'Grundbiicher' of their districts. Mere possession for forty-four years, or possessory titles of ten years' duration, with mima fucie evidence that such had a legal commencement, were accepted; lesser titles required stricter proof. Like the Torrens Act, the Prussian law provides an insurance fund.

The foundation was already laid in Prussia for the introduction of registration, and in Australia titles were scarcely old enough to be complicated: but although some additional difficulties impede the establishment of this system in this country, the titles which are to be registered here will, if entails are abolished, be simpler than in Prussia or Australia. Lord Halsbury's Bill, though in some points it necessarily creates dissatisfaction, makes the first attempt to simplify land transfer which offers real prospects of success. To be placed on the register little more is probably required than guaranteed titles. The gradual establishment of the system may be necessary on the score of expense, but it is an undoubted blot upon the Bill. By the temporary employment of local solicitors, who are generally familiar with the titles by which the neighbouring land is held, the process of registration might be simultaneously and inexpensively effected, especially if only marketable titles are required for the 
first step in the proceeding. The exclusion of rightful owners in cases of error appears cruel; but it is less hard than our existing system, which confiscates the invested capital of innocent and bonch fide purchasers. The guarantee should, it is submitted, be paid at once to aggrieved purchasers, and the registrars should, in their names, enforce all their remedies against fraudulent vendors. It is greatly to be hoped that a Bill, the adrantages of which are so numerous, will be speedily passed.

The system is not new in this country, but as old as the Norman Conquest. Registrars resemble Stewards of Copyhold Courts, to whom the old estate is surrendered and by whom the new one is granted. Titles cease to be derivative, and rest upon the last entry in the registry; examinations, abstracts, deeds disappear; landowners can carry their certificates of ownership in their waistcoat pockets. Since mortgagees need not receive the legal estate, or 'sit upon their deeds,' mortgages are effected with the utmost ease for such small sums as $5 l$. or $10 l$., and foreclosure becomes a simple inexpensive process. Consequently charges will be effected at cheaper rates, and second mortgages will not be dearer than first. Land transfer by registration saves 90 per cent. in expense, prevents any possible litigation, is completed in a quarter of an hour, and is so simple a process that men of ordinary intelligence can safely transact their orrn business. No class is more interested in the remoral of legal cobwebs than the English landlords. Recent experience of landowning has not been favourable; future prospects are gloomy. They have been severely taught the danger of storing all their eggs in one basket, especially when the bottom has fallen out. Many must be anxious to sell. 
Whatever renders a commodity more marketable and more manageable adds to its value. The best chance of obtaining a reasonable price for land is to remove the fetters which restrain its transfer. From every point of view a reform of the land laws in the direction we have indicated wonld be a social and economical gain, but it is quite possible that increased facilities of transfer may encourage the consolidation as much as the diffusion of property.

If rents are permanently reduced, landlords must become their own agents. If increased production affords the remedy for agricultural collapse, scientific training is required by the tenant farmer. If the soil is to be tilled in small holdings, or by a peasant proprietary, preparation must be made to educate them for the task. Thus, from every point of view, education becomes an indispensable condition in the future of agriculture. In England little provision is made to supply the want. Our manufacturers woke from their dreams of industrial supremacy to find that technical schools on the Continent had in a few years counterbalanced the advantages this country had gained from an early start. It is not impossible that our agriculturists may, from the same cause, find themselves left behind in the race. Continental Europe is rich in the supply of teaching adapted to the wants of every class. Even Ireland possesses sixty tax-supported farm schools. In Great Britain the State subscribes a grant towards the teaching of agriculture in the Science and Art Department of Kensington ${ }^{1}$ and contributes $150 l$. a year to the

1 Kensington is a curious place for an agricultural department. Within the last year the number of students has increased by 25 per cent. In 1885 there were eight ; in 1886 there were twelve agricultural pupils. The Australian Colonies have recently increased facilities for agricultural education. In Victoria, for instance, a central college is to 
endowment of a professorial chair at Edinburgh; private enterprise provides Cirencester, Downton, and Aspatria; agricultural societies offer examinations and prizes; and farming is taught in some of the country schools. Scotland, as usual, leads the van of education. Edinburgh University has recently formulated an exhaustive scheme for examinations in agricultural science. The examinations established by the Surveyor's' Institute for land agents attract an increasing number of candidates. Night schools for teaching scientific agriculture lave been at work for three years with considerable success in Aberdeenshire and Forfarshire. But, if the country is on the eve of an agricultural revolution so great as the creation of a peasant proprietary, or even the multiplication of small holdings, something more is required than isolated efforts. A glance at the means provided in some of the principal European states may bring home to us our relative deficiencies, and mrge the country to inaugurate a new departure.

A sketch has already been given of the French system. France has an organised system of education which works with great efficiency, and to which it annually devotes 70,000l. It is designed to encourage men of science to experiment in chemistry and machinery, to afford practical as well as theoretical instruction to landed proprietors, agents, and farmers, to train up intelligent peasant proprietors and labourers. For these objects there are four grades of schools. In most of the departments model farms, or fermes exemplaires, are established for farm labourers; provincial schools are carried on for bailiffs

be founded at Melbourne, and a new farm school is to be established at Longerenong. It is expected that the existing farm school at Dookie will show a profit for 1887 . 
and farmers, as well as higher grade schools, like Grignon, for landed proprietors and estate agents; and finally the Institut Agronomique supplies every appliance that is required for scientific investigation. There are besides special schools, and veterinary schools at Alfort, Lyons, and Toulouse. In many of the primary scliools agriculture is taught. and to some of the normal schools land is attached for practical teaching: each department already is, or shortly will be, pervaded by a peripatetic professor.

In the Austrian Empire the school of Krumman was founded so far back as 1799. There are now, scattered through the country, three smperior, four middle-class, and seven lower agricultural schools; there are also several special establishments in which instruction is afforded in such branches as shepherding, bee-keeping, grape and orchard management.

The dairy schools of Denmark have already enabled Danish farmers to rival English produce in London markets. Belgium, Italy, Norway, Saxony, Sweden, are all more amply provided with means of general edncation in agricnlture than England. As France has her Institut National Agronomique, Germany has her Institute; the Agricultural Sections of Jena, Poppelsdorf, Bonn, or Göttingen correspond to Grignon and the écoles nationales; the Landwirthschaftschulen to the écoles pratiques, the Ackerbauschulen to the fermes écoles. In Prussia more than thirty institutions teach the practice and theory of agricnlture; Möglin, founded in 1806 by Thaer, the Arthur Young of Germany, offers education of the highest class; Annaberg trains peasant farmers and bailiffs; in twelve primary schools agricultural pupils act as hired servants, and do the work of the model farms; itinerant 
teachers are paid by the Government to travel from village to village. There are also thirteen special schools in which such subjects as meadow culture, flax dressing, and gardening are taught. ${ }^{1}$

Württemberg is especially well provided with means of agricultural education. Besides the Royal Institution of Hohenheim, there are three school farms, an agricultural chair at Tübingen, and a veterinary school at Stuttgard. On many large farms there are apprenticed pupils preparing for Hohenheim. Voluntary winter schools, obligatory evening schools, and lecture meetings enable farmers to keep pace with the latest scientific discoveries. Practical agriculturists, in the pay of the State, visit the different districts, discuss special branches of farming, and co-operate with local associations in experiments and improvements. In all these countries admirable means exist for diffusing agricultural knowledge, and bringing home to the smallest farmers the best modes of cultivation. Scientific instruction is given in a practical form, and in a shape which is easily comprehended.

Almost every nation on the Continent is better provided with means of agricultural education than England, and a Committee of the Royal Agricultural Society is now

1 After the emancipation of the serfs, Russia recognised the urgent need of spreading among the mass a rational knowledge of agriculture. She has her agricultural museums, her three grades of primary, secondary, and higher education, as well as special schools adapted to the wants of different districts. Bavaria, besides large institutions at Weihenstephan near Munich, Lichtenhof, and Schleissheim, has agricultural sections in all the technical schools. Hesse possesses an agricultural eollege at Darmstadt, open to young farmers from November 1 to March 31. Courses are given for the benefit of national school. masters; botany, physics, and chemistry are taught in the national schools; wanderlehrer impart instruction in the villages, visiting their circuits every year, so as to be able to note improvement. 
investigating our deficiencies. The course is often too ambitious and laid out on too large a scale; but every tiller of the soil has the opportunity of learning the principles of his art, and of using to the utmost advantage the materials at his command. In every other department of hnman knowledge, where practice depends upon science, the shortest road to success is the mastery of general principles; in other words, theoretical investigation. The truth of this fact, as applied to agriculture, is ignored by the State in England. The art is carried to considerable perfection, but the science is neglected. Our farmers are skilful in the practice of received principles; they despise the general laws on which those principles depend; to them agriculture is only a collection of accepted precepts. Science has turned many traditions upside down; it may have a similar revolution in store for farming. The principles of scientific agriculture must be explored by men of science, and applied by men of practice; but a better understanding between the two can only be obtained by education. Every farmer does not require the highest scientific training; but, even in his isolated experiments, some knowledge of physics, chemistry, botany, or geology is useful, if it only teaches him what to avoid, and how to apply the results of the work of others. Doctors' boys do not qualify as practitioners by delivering medicines; nor do tillers of the soil become farmers by learning a traditional round.

Landlords require education as much as any of the classes which are interested in the cultivation of the soil. They alone have, to some extent, the means of supplying their want. In the future many must manage their own properties. Even if they can afford the luxury of an agent, it seems absurd to surrender to others the practical control 
of their estates. From this point of view it might be advantageous to introduce applied agricultural chemistry into the Science Schools of Oxford and Cambridge. At Oxford Mr. Primrose McConnell has tanght agriculture with marked success to the selected candidates for the Indian Civil Service.

To occupiers and cultivators of the soil, the value of agricultural education needs no demonstration. Unlike the landlords, their wants in this respect are inadequately, or not at all supplied. One feature, at least, in the continental system of education imperatively requires introduction into England. Account-keeping is as essential for farmers as for tradesmen. Chalkmarks on backs of doors or scattered notes in memorandum books will never show farmers how they stand, or in what special department they are losing money. On the Continent book-keeping forms a prominent feature of agricultural education. Pupils write journals of everything done on the farm, make particular notes of special work done and of the workmen employed, keep cashbooks of payments, sales, accounts with the house, and accounts of separate departments. If the way is to be paved for the growth of a peasant tenantry or proprietary, farm accounts should become a feature in all the rural schools of England.

Farmers, if rich enough, are to some extent able to gratify their children's wish for education in farming subjects. Experience shows that the wish is rare. Large sums of money have been voted by Congress to found agricultural schools for farmers' sons in America; but very few avail themselves of their exceptional advantages. Even for the wealthier classes of agriculturists much remains to be done. But no agricultural teaching of any sort is provided for labourers. And it is here that the greatest need 
is felt. In rural districts boys lose practical training to gain the three R's, and acquire in the process a distaste for farming occupations. Thus farmers suffer in two ways : they pay men's wages for boys' work, and labour is less efficient. Elementary education in the first principles of agriculture wonld go far to mitigate these evils. At the present day children in rural schools learn to read from books which are useless; their object lessons are polar bears or creatures with which they are equally unfamiliar; the natural history of horses, cattle, sheep, pigs, and ponltry, or insects and birds, is entirely neglected; they know more of glacial action than they do of air and water ; their minds are stnffed with historical facts, but of the nature of soils, seeds, grasses, or trees they are probably entirely igmorant. If after passing a certain standard, say the third, they received technical edncation in the work of their future lives, practically illustrated from a few acres attached, as is often the case on the Continent, to the school itself, they would be better equipped as labourers, and would take intelligent interest in work which to them is now dreary routine.

Hitherto agricultural progress has, in this country, depended entirely upon private enterprise. But as agriculture grows more scientific and landlords more impoverished, the need of a State Department of Agricnlture is urged upon Government with increased force. Something is already done in this direction, but much remains. The Agricultural Department of the Privy Council, which already commands the services of Professor Brown, has been recently strengthened by the appointment of $\mathrm{Mr}$. Whitehead as agricultural adviser. State aid is also given to horse-breeding. The Government devoted $5,000 \mathrm{l}$. for this purpose in 1888, and appointed a committee to frame a scheme for its distribn- 
tion. They propose to offer twenty-two prizes, or 'Queen's Premiums,' of 200l. each, to thoroughbred stallions, in the hope of securing the serrice, at nominal fees of $2 l$., of firstclass thoronghbred sires in every district in England. They are also considering the German and French systems of State haras, and the improvement of the old English strains fostered by the Cleveland, Hackney, and Coaching Horse Societies. It is also probable that the Committee upon Dairy Produce may suggest some technical education in butter and cheese making. In other directions the want of an Agricultural Department is severely felt, as, for example, to stamp out swine-fever and pleuro-pneumonia, and to give reliable analyses of artificial manures or reports upon seed samples. In this last direction technical education may supply farmers with the necessary knowledge, but meanwhile the loss is heavy.

State departments for agricnlture already exist abroad. ${ }^{\text {? }}$ Some account has been given of State aid to farming in France. It may be interesting to illustrate the practical working of that system. In the antumn of 1887 M. Barbe, Minister for Agriculture in the Ronvier administration, issued two circulars. In the first, which was addressed to the Prefects, he calls attention to the black rot, a new disease among vines in the Garonne district,

1 Germany has a powerfully equipped Ministry of Agriculture for Agriculture, Domains, and Forests. In the United States the Central Department of Agriculture is divided into 12 branches, each presided over by a separate officer directly responsible to the Minister of Agriculture for the work of his division. Thus the Seed Division purchases, tests, examines, reports upon seeds, experiments in their cultivation, and ascertains the localities to which they are best suited. The other divisions are (2) Botany, including plants and grasses; (3) Mycology, which investigates diseases of trees and plants caused by fungi; (4) the Microscope; (5) Forestry; (6) Ornithology ; (7) Mammology ; (8) Pomology, for the assistance of fruit-growers; (9) Chemistry; (10) Entomology; (11) Veterinary Science; (12) Statistics. 
notices certain insect pests which destroy farm crops, directs that farmers shall be invited to give notice of their attack, and requires Prefects and Professors to investigate the subject, and, if possible, devise the appropriate remedy. In the second circular, addressed to the departmental Professors of Agriculture, M. Barbe insists on the losses caused by bad seed, and directs his subordinates to call public attention to the Govermment Seed Trial Station, established three years ago at the office of the National Agricultural Institute in Paris. It may be added that the Institute, to which are attached experimental farms and laboratories at Joinville, inquires into methods of cultivation, examines and reports upon samples of seed which farmers propose to buy, or investigates the introduction of new varieties, and the amelioration of those already introduced. The Professors of the Institute, which is temporarily located in the Conservatoire des Arts et Métiers, include the best known specialists of the day, and its director, M. Engene Risler, enjoys a European reputation as a scientific agriculturist.

Another point, in which legistation is urgently needed, is the revision of Railway Rates. The question is less simple than it at first sight appears. But the grievance of English farmer's is real and substantial.

Three modes of rating have been proposed : (i.) equal mileage rates; (ii.) rates regulated by costs of conveyance; (iii.) differential rates. The third is the principle adopted in England.

Equal mileage rates are manifestly unfair, because it is reasonable to consider the costs of construction from point to point on the same line, the steepness of the gradients or other costs of service. It may be also conceded that consumers derive advantage from special through rates for long 
distances, and that it is only by their means that London draws fish from Hull, meat from Aberdeen, regetables from Penzance, and sweeps a radius of 150 miles for her milk supply. But the inexpediency of charging on the same scale for long distances as for short does not make it fair to charge higher rates for short distances than for long. You cannot argne in the same breath that consumers gain by placing remote markets on the same footing as near, and by placing near markets on a worse footing than those which are remote.

But the case against through rates for foreign perishable produce is still stronger. Foreign produce may be brought to London partly by sea and partly by land, or wholly by sea. If goods are imperishable, if quick delivery is not essential to their good condition, if they do not suffer by delay in transit, foreign producers may choose either mode of conveyance. They naturally choose the cheapest. In this case, if low railway rates encourage foreigners to send their goods partly by land, English producer's are little, and possibly not at all, injured. Their grievance would be formulated thus. Railway companies admit that they carry at a profit hops from Flushing to London for $25 s$; therefore their profit must be enormous on the same weight of hops at $36 \mathrm{~s}$. $8 d$. from Sittingbourne to London. It is only by charging local producers high that they can so cheapen rates for foreigners as to secure their traffic. The answer would probably be: Kentish hop-growers pay more, because they can only employ land carriage; foreigners can send by sea, and it is this competition between two modes of conveyance that determines the cheapness of the rates.

But there is no such competition possible in the case of perishable produce, such as butter, fruit, regetables, and 
fresh meat-the very commodities to which farmers are recommended, and peasant proprietors would be obliged, to turn their attention. Here time is of the essence; delay injures condition; quick transit is a necessity ; and consequently there is no natural competition between sea and land carriage. If perishable produce was sent to London by sea, it could not compete in quality with English goods. When, therefore, foreign perishable produce is sent through to London at through rates, which are actually less than those charged to local growers, and in fast trains from which local growers are excluded, the English farmer is indisputably injurerl. Here is no natural competition between sea and land carriage, both of which are available to the foreigner, to cheapen the through rates, but only the artificial competition, created by rivalry between competing companies, each seeking, in the interests of their respective shareholders, to outbid the other and attract the traffic to their own lines. Here, then, British farmers pay the carriage bills of their foreign rivals. It is iclle to plead the interests of the consumer ; they would be equally consulted if companies paid smaller dividends, and they cannot be selved at one and the same time by bringing remote markets to his door, and by driving near markets to a distance. Space is annihilated, but only if it is sufficiently great; food is cheapened, but only by bounties to foreign producers, and premiums on distance at the expense of proximity.

What is the remedy? Equal mileage rates are simple, but the simplicity is attained by the sacrifice of equity. Rates based on the cost of conveyance without reference to the value of the articles are financially unsomnd. A ton of sand would pay the same as a ton of copper, or a hundredweight of fresh beef as a hundredweight of potatoes. On 
the whole, differential rates, if fairly worked, are the most equitable system. But in no case should special import rates be actually lower for long than for short distances, and a different scale should be provided if the perishable character of the article precludes natural competition between land and sea carriage. The scale of rates should be published in a clear, intelligible form, and an appeal should lie to a Board of Control, whose decisions should bind the companies. Such Boards of Control are no novelties. In Holland, Belgium, and France the Government retains power to adjust rates in the public interest. In Prussia, and the German Empire generally, similar powers are vested in Conciliation Boards. It is true that in these countries railways were partly built by the State; but the common principle is that, if railways are primarily commercial undertakings, they are endowed with exceptional powers, because they are designed to develop, and not to cripple, the resources of the country. 


\section{CHAPTER XVII.}

FISCAL RELIEF. FRO'TECTION PRICES AND PROTECTION TAXES, OR FREE TRADE TAXES AND FREE TRADE PRICES.

REstoRED confidence, larger powers of dealing with their land, increased practical and scientific knowledge, welldirected State assistance, revised railway rates, may infuse new life into landlords and tenants. But their special public grievance is the unfair incidence of local taxation. At the present moment agriculturists are oppressed by Protection taxes upon Free Trade prices. In the debates on the Repeal of the Corn Laws, both Sir Robert Peel and Lord John Russell argued that the removal of the burdens upon land must necessarily accompany the extinction of its immunities and privileges. So long as consumers of agricultural produce were heavily taxed through import duties for the benefit of producers, it was but reasonable that agricultural land should bear the largest share of the burden of rates. But from 1848 onwards that reason ceased to apply. Free Trade ought, in common justice, to go hand in hand with fair taxation. Yet legislators continue to burden agricultural land, as if the community was still burdened for its support. Rates are charged with innumerable items of national concern, inseparable from civilisation or social organisation; and existing arrangements exhibit a chaos of areas, districts, and local authorities, in which national and local purposes are confusedly 
intermingled. A comprehensive measure of local government is alleged to be the only ultimate remedy; but meanwhile the plea is made a subterfuge to evade that relief, the justice of which the proposed reform itself concedes.

Taxation of land mainly consists in (1) the Land Tax; (2) Local Taxes. It is often contended that landlords have evaded payment of the Land Tax by reducing it to insignificance. But, in the first place, the true representative of the Land Tax for national purposes is Schedule A of the Income Tax. In the second place, the evasion of payment is not by realty but by personalty. In its existing form the Land Tax dates from 1692, when a new assessment was made; but it undoubtedly represents a part of the ancient subsidies, scutages, hidages, and tallages. Present inequalities, increased by partial redemptions, sprang from the politics of the Revolution; the counties in which it was heaviest were most attached to the House of Stuart. The Land Tax, following the practice of the ancient subsidies, which it represents, originally applied to personalty as well as to realty, but the difficulty of assessing the former proved so great, that in 1833 the net receipts only amounted to 5,2117., and in that year an Act was passed abolishing its application to personalty. So far as the Land Tax is concerned, it is personalty, not realty, that has evaded payment. It is not, however, by abolition of the Land Tax, which at the best would afford but partial relief, that landlords should seek redress. The Land Tax is an old tax, subject to which estates in this country have all been acquired.

Local Taxation consists of old and new rates. The old rates were the following (1) Poor Rates, (2) County Rates, (3) Highway Rates, (4) Church Rates. To these must be added other rates which fell upon land, such as 
Light and Watching Rates, Sewers Rates (not Metropolitan), Drainage and Inclosure Rates. The amounts of this last class are not separately retmined in early reports on Local Taxation.

The four first-mentioned rates formed the chief items of Local Taxation. If, as it is believed, the value of agricultural land has fallen to about the value of 1815 , it becomes not only historically, but practically, interesting to give the amount of Local Taxation so far as it can be made ont in 1815,1827 , and $18+1$. The total amount, and, where practicable, the items, will be found set out in the note, ${ }^{1}$ and in Appendix XIII. These years, it will be observed, are jears in which it was reasonable that Local Taxation shonld fall heavily upon agricultural land, because, nnder the protective system, the community at large was heavily taxed for its support.

In 1848 England adopted a Free Trade Policy, but she did not readjust her Protection taxes. On the contrary, she has every year added to the burden upon agricultural land. In reason, if agriculturists have no Protection, they ought to have fair taxation; in fact, they have neither. Personalty or building land eats its cake in the form of Free Trade, and keeps it in the shape of relief from taxation. House property never had, and therefore never lost, the benefit of Protection; but it is in building land that the increased valne of the soil now consists. The whole force of the double blow inflicted by the loss of

1 The returns in early reports for any given year supply the item of one rate, another supplies a second, but 1827 is the first year in which all four are given. In 1803 and 1814 Poor Rate was 5,348,205l. and $8,388,974 l$; in 1792 , County Rate was $218,215 l$; in $1803,317,977 l$; in $1814,573,504 l$. Highway Rates averaged for the three years 1811-12-13, $1,407,200 l$; in 1827 , Church Rates were 564,3887 . For other details, see Appendix XIII. 
Protection and by increased taxation without commensurate increase in value, has fallen upon agricultural land, and it is agricultural land alone that requires relief. As a curious comment upon the existing crisis in England, it may be noted that when, in 1884, the proposed protective duties were referred to a French committee of deputies, an amendment was moved and carried, remitting the whole of the Land Tax, except that portion which was assessed on vineyards and building land; but the Chamber and the Senate preferred Protection. In England justice imperatively demands the remission of taxation on agricultural land. Such a measure is due of right to agriculturists as the necessary consequence of Free Trade; it was promised in 1848; it is virtually conceded in every Treasury subvention; it is implied in the repeated answer that landlords must wait for Local Government Reform; it has been accepted by several resolutions of the House of Commons; it has been recommended by recent commissions on agriculture.

In 1815 the rental of England and Wales was $36,000,000 l$. ; in 1878 it was 51,000,000l. But at least 35 or 40 per cent. reduction has been made in 1887. At this moment rents are certainly no higher, possibly they are lower than in 1815. Again, in 1815 foreign corn was excluded under $80 \mathrm{~s}$. a quarter, and the duty acted as an income tax on the wages of consumers to enable producers to bear the charges upon land. In 1887 there is no import duty, and no tax paid by the community for the benefit of the producer. Again, in 1815 agricultural land paid an enormous proportion of poor. rate, because ratepayers contributed to the farmer's labour bill; but in 1834 the Poor Law system was totally changed, and farmers now pay wages from their own pockets. Are, then, local bur- 
dens readjusted? Are they lightened? On the contrary, they are enormously increased. Agricultural land is

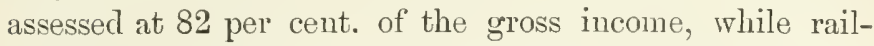
ways, mines, and houses, which alone enjoy the so-called unearned increment, escape respectively at 31,42 , and 77 per cent. Once this was just, now it is flagrantly unjust. New charges have been thrown upon agricultural land: as local burdens, education rates are glaring anomalies; ratepayers have lost their tolls and the whole maintenance of highways falls upon the landed interests, though it is the brewer or the coal merchant who makes the profitable use of roads. If landlords and tenants invest capital in improvements, or borrow money and similarly apply it, they are assessed upon the improvements. If they invest in the funds they escape, as does the mortgagee who holds a charge upon the land. Is it then surprising that farming improvements, in these hard times, are not effected ? Traders, fundholders, mannfacturers enjoy a regulated system of poor law, security of life and property, and wellkept roads for nothing; owners and occupiers of land at the cost of millions. Not only are new charges thrown upon agricultural land, and old means of assistance withdrawn, but, item by item, with the exception of church rate, every one of the old charges ${ }^{1}$ is increased, and this upon what is possibly a lower income than that of 1815, when Protection prevailed, and when the Poor Law acted as a wages fund. Mr. Goschen, in the conclusion of his report on Local Taxation, ${ }^{2}$ says of 1868 , 'An historical retrospect seems to prove that, as regards the burdens on land, they are not heavier than they have been at various periods of this century.' But, with all deference to his eminent

1 See Appendix Xill, Local Taxation.

2 Parliamentary Accounts and Papers, 1870, vol. lv. 
authority, his historical retrospect is only an historical squint if it fails to notice the two most prominent features of early local taxation-first, that, as regards rates generally, agricultural land was heavily burdened because it enjoyed, so to speak, a drawback in protective duties; secondly, that, as regards poor rates in particular, agricultural land was heavily burdened because, prior to 1834 , the administration of the Poor Law taxed the community to pay the farmer's labour bill. The two reasons for the burden are now gone, but not the load; rather it is, in the past trenty years, enormonsly increased. The climax of injustice has been reached within the last ten years, when distress has increased rates by more than a third. Agricultural depression raises the value of realised personalty, because it cheapens the cost of food, but it proportionately lowers the value of agricultural land. The property which profits by depressicn escapes scot free from the burden of local taxation, which falls more heavily upon agricultural land as its value declines.

It would not suffice to show, even if it were possible, that the burden of local taxation is the same in 1888 as in 1841. The following comparison between the figures of the four old rates in 1841 and 1885 shows that it is higher by $3 \frac{1}{2}$ millions. In both cases the Metropolitan expenditure muder the heads of Poor Law Authorities and Churchwardens (church rates) is included :-

1 This date is chosen in preference to 1827 , because the new Poor Law had then come into operation, while Protection still continued. In other words, that year is the simplest of the two detailed returns in the period of Protection, becanse one great factor which previously swelled rates in the interests of agricuitural land is eliminated. 


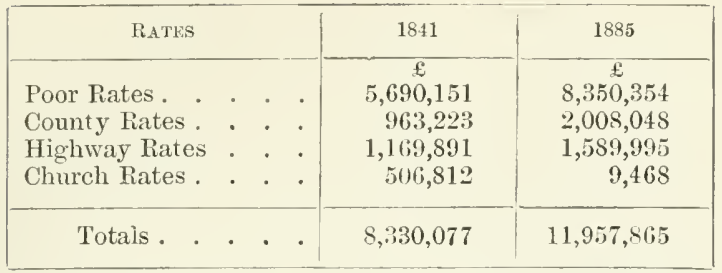

To this comparison must be added the facts that, in 1841 , turupike tolls amounted to $1,318,081 l$. ; that of the old rates, Sewers Rates, Drainage, Embankment, and Conservancy Rates, and Burial Board Rates are all increased; that a new rate falling wholly upon the land, the Rural Sanitary Rate, amonnts to $313,724 l$. ; and that the School Board Rate, partly urban, partly rural, has risen to $1,320,923 l{ }^{1}$

Since 1815 the total sum levied by local rates has risen from 8 millions to more than 26 millions in 1885. By far the largest share of the increased burden falls upon towns, and the Treasury subventions must also be considered $(3,773,610 l$. in 1885). But it will hardly be disputed that not less than 2 millions of additional taxes have fallen upon rural districts, in which the value of property has, if anything, decreased, which now derive less direct benefits from a large portion of the expenditure than heretofore, and which no longer enjoy the compensating advantages of the protective system. In strict justice, if the principle was carried out upon which land was originally burdened, the agricultural interests are entitled to be placed, with regard to local taxation, in a better position than they enjoyed iu 1815, when the total amount raised by rates was 8 millions instead of 26 millions. Their present position is that of

For the detailed comparison of the rates in 1841 and 1885 , see Appendix XIII. 
Protection taxes and Free Trade prices; they are, therefore, abundantly justified in demanding either Protection prices or Free Trade taxes.

It will be admitted on all sides that Local Government Reform is necessary. Local organisations growing up haphazard, and created from hand to mouth, are needlessly complicated, and the spread of population intensifies their ineffectiveness. The mischief is brought home to ratepayers by the astounding growth of local debt. Between 1868 and 1885 local rates, exclusive of tolls, dues, and rents, rose from 16 to 26 millions, while during the same period Imperial taxation, excluding the Post Office, and miscellaneous receipts, only increased from $48,570,000 l$. in 1868 to $53,223,000 l$. in 1885 . During the ten years ending in 1884 the liabilities of the local authorities, in respect of outstanding loans, rase from 93 to 165 millions, and at the present moment the local debt is little less than a fourth of the National Debt. This enormous burden accumulates unchecked, if not encouraged, by its interested administrators. Ratepayers, aghast at the amount of their indebtedness, cannot see, much less control, its growth, their pockets are emptied on every side by local bodies, each invested with large powers to tax or borrow They cannot, at the same moment, keep an eye on quarter sessions, vestries, burial boards, sanitary boards, poor law guardians, parish overseers, drainage or sewers commissioners. Thus this burden grows day by day, uncontrolled by any central body, affecting different aress in different degrees, each portion administered by different authorities, elected on different methods, exercising their respective powers over intermingled areas which are not conterminous, and enjoying a practical anarchy and collective irresponsibility. A strong central body with consolidated 
powers, is imperatively needed to enforce economy, promote efficiency, and exercise control over convenientlysized and well-arranged districts.

But administrative reform ought not to hinder financial relief. Excessive taxation and its wasteful distribution are two distinct abuses capable of separate removal. Whatever portion of local taxation is reduced for agriculturists must be necessarily transferred to some other form of property. Nor would it be difficult to establish a local taxation income-tax, and use existing returns to assess realised personalty. But if this method of supplying the deficiency is rejected, other alternatives exist. Subventions from general taxation are clumsy expedients, but the State supervision which they carry with them, if reform of local government is postponed, becomes a valuable advantage. Another and simpler method of relief is afforded by the allocation of certain taxes, like the dog, gun, game, and carriage licenses, to local authorities. ${ }^{1}$

But the mode of financial relief hardly belongs to the present inquiry, which is not so much intended to suggest remedies as to insist upon the unfair incidence of protection taxes upon agricultural land. Here, and not in its incidence upon building-land, lies the inequality of the present system. Here, whatever increment bas been gained is hardly earned, and here alone is relief urgently required.

It is often argued that the reduction of local rates exonerates property at the cost of labour, and quarters landlords upon the State. Though the reduction of local rates is primarily a landlord's question, because upon him

1 Another financial measure which would indirectly confer substantial benefits upon agricultural land would be the reduction of 3 per cent. consols to $2 \frac{1}{2}$ per cent. By such a change capital would be necessarily attracted from comsols to land, since both would then be placed upon mach the same footing as remunerative investments. 
falls three-fourths of the charge, yet the interests of farmers are not limited to the remaining fourth. They are strong enough to secure reduced rents as a consequence of remission. Again, the existing incidence of local taxation would necessarily prevent the growth of small owners, the spoilt children of those who use this argument against any reduction in the burden of rates. It is a novel mode of encouraging peasant proprietors to tax them more heavily than any other class in the community. Unless the soil is partially relieved from rates, the dreams of extreme land-reformers are impossible of realisation. 


\section{CHAPTER XVIII. \\ SELF-HELP NOT PROTECTION.}

Legislatiox and financial reform may, and, it is hoped, will, do something for agriculture; but it can, and must, do most for itself. State aid may be a good crutch; it is certainly a bad leg. The only certain and immediate assistance comes from self-help. When the situation is looked fairly in the face, foreign competition in corn is seen to be, for the present at least, a fixed quantity. If agriculturists expect foreign wheat supplies to cease, they may starve where they stand, like Horace's rustic waiting for the river to cease to flow. It is true that American or Indian grain production and population will some day run neck and neck; but few of the present generation of men will live to see that agricultural millennium. It is so inherently improbable that import duties on wheat will ever be imposed, that farmers only follow the will-o'the-wisp of Protection to be lured still deeper into the Slough of Despond. Agriculturists must therefore revise their practical ideas, if they cannot, in this respect, revise the fiscal system. From other sources relief will be but infinitesimal.

Where, then, are agriculturists to look for a livelihood? In 1886 the total value of imports of agricultural produce ${ }^{1}$ amounts, in round figures, to 113 millions of pounds. Of this total value, $62 \frac{1}{2}$ millions consisted either of grain, not

1 See Appendix VIII., Values of Imports of Agricultural Produce. 
including Indian corn (3う millions), or of articles which either cannot be produced at all or cannot be grown

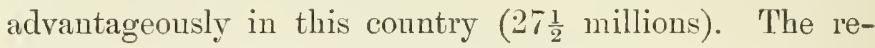
maining $50 \frac{1}{2}$ millions consists, for the most part, of produce which not only might be produced in this country, but, if railway rates were readjusted, could be produced with equal advantage nowhere else. Excluding salt and preserved meat, cheese, margarine, and lard, which are not perishable, and therefore could be conveyed here by sea, we annually import from abroad perishable produce, such as livestock, fresh meat, butter, eggs, fruit, and vegetables, of the enormous value of $30,600,0007$. This sum, which exceeds the total value of the imported wheat by $1 \frac{1}{2}$ millions, can be produced at home under superior advantages of proximity.

Our foreign meat supply arrives alive or dead. In the first case, English farmers suffer constant risk from imported contagious disease. Against this influx of living beef and mutton, if not unduly favoured by railway rates, English farmers can and must contend. But imported livestock should not be suffered to spread infection among the flocks and herds of this country. In France veterinary officers belonging to the Agricultural Department are stationed at all the ports of entry, armed with full powers to exclude or slaughter foreign livestock. In the Netherlands the vigorous action of the Ministry of Agriculture has stamped out pleuro-pneumonia. Why should not a similar practice prevail in England? So long as contagious diseases are not shut out, British farmers fight foreign meat-producers with one hand tied behind their backs. Railway rates tie up the other. Under no natural system of competition could 30 million pounds' worth of perishable produce be thrown upon the London markets in equal 
condition to English goods. If once the protective rates were revised, which now exclude home growers from home markets, English farmers would turn for profit to fresh perishable produce; and if they do so, there is an additional 6 millions of imported bacon, hams, and cheese, in the best qualities of which they might defy foreign competition. This $36 \frac{1}{2}$ millions probably amounts to more than the rental of farms in England and Wales in 1887.

History proves that farming has twice before changed its front. In the sixteenth century farmers turned from the plough to pasture; in the eighteenth and nineteenth centuries they reverted to tillage. Now, at the close of the nineteenth century, livestock and dairy-farming must supersede corn as the farmer's sheet-anchor. Changes of front in the faces of watchful rivals are dangerons manouvres, attended with risk and loss; but the sooner they are effected the better. There are signs that the new departure las in fact commenced; and its inevitable result, the decreased demand for agricultural labour, is lamentably manifest. The area of corn cultivation has decreased by 618,000 acres upon the area in $1875-7$; on the other hand, more land is under rotation grasses, clovers, and permanent pasture, or fruit orchards and market gardens.

Under changed conditions, agriculture begins to show faint symptoms of revival, which the scarcity of winter food, compensated as it was by abundant pasture up to December, has failed to check. Every county can produce instances of shrewd, industrious, persevering men who now farm with profit by adapting low-rented land to new requirements, by economy of labour and personal supervision. Holdings have been rednced in size, and the proportions of arable and pasture are better adapted to varied and diversified husbandry. Land once more yields 
a profit; the moccupied area is less in 1887 by 18,533 acres than it was in 1881 ; agricultural-implement makers report an increased demand for their goods. The invention of new dainy implements and processes, the study of foreign systems, the importation of American experts, the establishment of milk factories and creameries, the formation of associations and unions anong milk-producers, testify to the growing importance of dairy-farming.

The countrs, then, appears prepared to enter upon a great agricultural change. But withont cordial co-operation between owners and occupiers no new departure can succeed. Both profit by getting the utmost from the land; and the real question for both parties to consider is, How can eren-handed justice best be meted out to their respective interests? Landlords dislike to surrender control over their estates, and farmers dislike to risk capital on insecure tenures. Something may be said for both positions. But unless landlords find the whole capital, farmers have justice on their side.

Parties to contracts must, as a general rule, protect their own interests; but thongh farmers are now able to drive a bargain, their position is in some respects peculiar. The profession of a farmer is seldom lncrative, and he embarks in it everything that he has. He follows the most hereditary of callings; he cannot transfer himself and his money to other trades; he is as helpless as generations of farming can make him. It is the consciousness of this fact that drives him into ruinous competition for land. He may lose money on his farm, but he cannot readily throw up his holding, especially if he lias a family. It is often better for him to suffer an annual loss than to risk the auction sale which closes his occupation. He has little incentive to improvement ; he cannot patent his agricultural 
processes; till recently his landlord often appropriated in the shape of increased rent the results of his enterprise. He has no benefit of fancy prices for his produce; he cannot wait his market, for his goods snffer in the keeping; he is deprived by railway rates of the natnral protection afforded by distance; he is subjected, without the favour of fashion, to the barest competition; his scanty profits are intercepted by middlemen, who stand between him and the producer.

On the other hand, if agricultural produce all round has decreased in value by 25 per cent., rents have fallen from 30 to 40 per cent., while seed corn, cake, mannre, or' store cattle and sheep are cheaper in proportion. Much, too, has of late been done for farmers. The Game Laws, ${ }^{1}$ which, for more than a century bred bitter feelings, have been modified. The law of distress, which, by giving artificial security to landlords, often raised rents above their natural level, is limited in its range. The old legal maxim 'Quicquid plantatu' solo accedit solo' is at least shaken. The present Government has removed some of the inequality of taxation by allowing farmers to declare their actual income under Schedule D. It has also protected them against adulterated produce, which robbed their dairy-farms of legitimate profits, ${ }^{2}$ or their purchases in cake of half their valne. ${ }^{3}$ But snch remedies only touch

${ }^{1}$ Game is no new grievance. In 1774, Arthur Young (Political Arithmetic, p. 204) speaks of the number of hares as ruinous to farming. In 1830 a pamphleteer, writing as Agricola, begs landlords to abandon their 'contemptible place-hunting battues,' the proceeds of which are 'destined for the London poulterer,' and speaks of the 'nursery of game ' as 'the stepping-stone to a sinecure.'

2 The Margarine Act. But it may be doubted whether the Act will effect its object. Perhaps the best legislative protection against the admixture with butter would have been to require it to be coloured red or pink.

\footnotetext{
3 The Merchandise Trude Warks Act.
} 
the fringe of the farmer's difficulties. His real grievance against the landlord is the absence of security for unexhausted improvements under a lease. Ownership affords the strongest encouragement to agricultural progress. On large estates it cannot be combined with occupation; the relations of landlord and tenant must necessarily be maintained. Tenants of the class of cherclier's of agricultural industries are easily found, who cultivate the soil as lodgers, skim and rob the land, and reduce farming to leave to an exact science. But how can improving furmers be induced to hire land? Three plans have been proposed. The first is to create peasant proprietors; the second is to recognise that dual ownership which is involved in tenant-right; the third, and most feasible proposition, is to secure to the tenant in the fullest degree the benefit of the improvements which he effects. English farmers have no claim to fixity of tenure; but they may fairly ask, and are entitled to obtain, absolute security for their outlay.

With high farming, tenant-right, in some form or other, became an absolute necessity ; but the Legislature proved slow to recognise the change in agricultural conditions. Although the need of maintaining the fertility of the soil increased every year, modern tenants possessed no more security for outlay than medieval farmers who never put a sixpence into the soil. How compensation should be given is a much-debated question. Holdings acquire additional value in three ways: first, by permanent improvements effected by the landlord; secondly, by artificial manures which produce a temporary increase in the fertility of the soil ; thirdly, by a course of skilful farming, the effects of which last for years, but are capable of exhaustion. No question arises on the first head, and very little on the 
second; the real difficulty begins with the third. If tenants, by skill and liberality, liave increased the letting or marketable valne of land, they are entitled to compensation for whatever increase remains when landlords seek to change the conditions of a tenancy. Thus, even on the third head, difficulty only arises when, at the expiration of a lease, a notice to quit is given, or the rent is raised. In order to ascertain the valne of the tenant's improvements, two plans are proposed-open sale in the market, and valuation with arbitration. The first is the free sale of tenant-right; the second is the principle adopted in the Agricultural Holdings Acts of 1975 and 1883. One fatal objection may be urged against the first plan. The incoming tenant buys the improvements; in other words, he enters upon the farm with his capital reduced, if not exhausted. Farmers, in fact, cut a stick for their own backs. On other grounds the three $\mathrm{F}$ s, with the attendant tutelage of a land court, are not only historically indefensible, but mnecessary and unfair to English landlords.

To quitting tenants, the principle of reference and arbitration, adopted in the Agricultural Holdings Acts of $187 j$. and 1883, affords adequate security. The latter Act is compulsory, and therefore escapes the danger which made the first inoperative. But its provisions are cumbersome, and its schedules of improvement minute but inadequate. It gives no security to sitting tenants against a rise of rent based upon their improvements. If they refuse the rise, their alternative is to quit. 'The choice is rnfair; the losses on a sale preparatory to quitting a farm often amount to ruin; countless considerations besides those of business induce tenants to consent to a rise which they cannot afford. The adrantage taken of this dilemma negatived the intended results of the Irish Land Act of 
1870 , and was made the excuse for the three F's of 188.3. For the present time in Fingland, the parts are rerersed; land competes for tenants, not tenants for land. But it will not always remain so, and tenant farmers lave now the opportunity of, as it were, legislating for themselves. Ample security might be given by a very simple bill, dealing with the principle of compensation, the mode of its assessment, and the manner of its parment. The broad principle is, that when changes in the condition of a tenancy are proposed, tenants are entitled to compensation for any additions which their skill and capital have made to the letting value of the land: landlords are entitled to similar compensation for any diminution caused by niggardly or negligent farming. The value of the addition must be calculated by reference to experts and arbitration, and the amount limited to seven years' purchase, the period within which it would generally be exhausted. Lastly, in the case of quitting tenants the compensation thus estimated and capitalised should be paid by or to landlords on the surrender of the farm; in the case of sitting tenants the compensation should either be paid by the landlord in a capitalised sum, or be for seven years deducted from the increased rent. A measure constructed mpon these lines would give tenants every necessary security and inducement for skilful and liberal farm management.

But even if compensation were thus secured, many agreements are objectionable on account both of their contents and their omissions. Restrictions upon cropping or sales of produce belong to bygone conditions of farming, and fail to achieve their objects. If it is necessary to guard against the impoverishment of the land in the interests of the owner or the incoming tenant, the best protection, next to the interests of the occupier himself, will 
be to prescribe the annual quantity of manure, and the course of the latter year's cultivation. To the class of omissions belongs the want of a sliding scale to adjust rents to the rise or fall of prices. Without such a scale a fall in the value of agricultural produce places tenants under leases at the mercy of landlords. The following system is, it is believed, adopted on Lord Tollemache's estates; and although difficulties may arise in working out the percentages of the rise and fall, the fairness of the principle admits of no dispute.

Average price of three cropls. $s . d$.

410

116

390

$36 \quad 0$

310

Standard $31 \quad 6$

290

$26 \quad 0$

$24 \quad 0$

216

190 liise or fall upon the rents.

Rise of 25 per cent.

, 20 ,

, $15 \quad$,

," $10 \quad$,

, $5 \quad$,

$\begin{array}{crr}\text { Fall of } & 5 & \\ , & 10 & , \\ , & 15 & , \\ , & 20 & , \\ , & 25 & ,\end{array}$

Upon this system, assuming the rent on which the standard is obtained to be $1 l$. an acre, if prices reach $44 \mathrm{~s}$. the rent only rises to $25 \mathrm{~s}$. an acre. On the other hand, if prices fall to $19 \mathrm{~s}$. the rent falls to $15 \mathrm{~s}$. The scale for the fall is less eqnitable than the scale for the rise. If prices fell so low as the two last figures, the surplus profit for rent would be a minus quantity. But though particular percentages might always be disputed, the principle of sliding scales and fluctuating rents is at once so reasonable and practicable, that its adoption would go far to remove those natural objections to leases which spring from fear of falling prices and fixer outgoings. Mutual confidence between landlord and tenant, jnst agreements, security for 
ontlay, freedom of and in contract, sliding scales for rent, wonld remove the principal hindrances which scare away improving tenants. Farms at present rentals may, it is believed, be marle to pay. Undoubtedly if farmers slumber in their empty corn-bins dreaming of Protection, they will be worn out before things wear round. But capable men of energy and enterprise, wide awake to every chance of profit-men who in personal expenses cut their coats to their cloth, who thoroughly understand and keep the master's eye upon their business-can, and do, make farming answer. They have, in many respects, rarely occupied a more favourable position; they have a choice of holdings and their own terms. But profits do not lie in the old ways, nor are fortunes to be expected. Profits lie in pennies saved rather than in pennies made-in careful planning, skilled management, economy of working expenses, minnte attention to detail. Many losses might be prevented or controlled if farmers more often remembered that no part of their holdings better repays tillage than their heads.

Profitable farming has been revolutionised by the annihilation of time and space, and the reduction of freights of ocean transit which steam and trade-depression have together effected. But agriculture, like some heavy body which has reached a high rate of speed, cannot be pulled up abruptly. The machinery las ceased to drive it forward, but the way that is still upon it carries it in the direction of wheat. Yet the mass shows signs of breaking off into different directions. Low farming takes the place of high because it is safer. Holdings are reduced in sizea change which may prove advantageous to agricultural labourers; breadths of arable land are diminished, and farms better proportioned for mixed farming. Dairying, 
livestock breeding, rearing, and fatting, are the most remunerative forms in which tenant farmers can employ their capital. Nor is it only to this or that side of the country that mixed farming is suited. It is sometimes said that one district grows wheat, another dairies, according to the value of the soil. But the example of France is not required to prove that stock may be bred and reared, and cheese and butter made, on arable land. Dairying is more a question of markets than of soil. It is true that the butter made in the rich pastures of Gournay and Isigny fetches from 2s. 6d. to $3 s$. 6 $d$. a pound in the Paris markets; but much of that which competes in English markets is produced on cultivated lands by the yield of tares, clover, roots, rye, and oats. Varied husbandry pays on light, shallow soils which will not produce a permanent grass. It employs more labour than land which is laid down permanently to grass. It also saves expenses both of men and horses, because it diminishes the area under the plongh, by substituting for three-fourths of the arable portion a three or four years' lea, which may be grazed or cut for hay. 'The system of rotation and temporary grass which it adopts costs less in seeds than permanent pastmre, and may be reconverted to tillage whenever necessary. It restores the fertility of arable soil, because it gives time for the vegetable matter to accumulate. It supplies fodder-crops, which in dry seasons, like 1887, are the saving of stock-breeder's and dairymen. It secures more profits from breeders and dealers, because more stock is reared at home and fewer 'stores' are purchased. It minimises the risk of contagions disease, because it Iessens the number of cattle which travel through the country; and not only is home-bred stock less liable to disease, but it is better suited to the soil and climate. It enables farmers to compete with foreigners in those forms of pro- 
duce in which proximity gives them natural advantages. It is, in fact, peculiarly adapted to the growth of beef, mutton, veal, butter, milk, and pork-articles in which home markets enjoy a natural monopoly, and the imported value of which annually exceeds 20 millions. It increases the proportion of livestock, and thus assists farmers to consume at home produce which they cannot sell at a profit. Better prices are realised in milk and butter than were made thirty years ago. Prime qualities of English hard cheese maintain their prices; there is an increasing demand for soft cheese of the Coulommier's type; buttermilk commands a ready sale among confectioners. If half-and-half cheese like Brie, or skim-milk cheese like Gervais, both famous in Paris, command no sale; if separated milk is not, as in the North, bought to mix with porridge, skimmilk may be used to rear calres and pigs with peculiar adrantage. Shorthorns, as is well known, take kindly to rearing by hand; and the excessive fatness which depreciates the price of maize-fed American 'hog-products' is best counteracted by nitrogenous food, like milk mixed with pea-meal or barley.

Where markets are convenient, the milk trade is easy and remunerative; but farmers have hitherto given away their profits to be reaped by middlemen. One of many signs that they are awakening to the importance of the trade is seen in their alliances to determine the prices of the districts. Co-operation in the sale of produce is sorely needed. It is probable that that uniformity which places Normandy at the head of the butter trade can only be secured in factories. If so, let us have them. But it is certain that if English cheese and butter are to compete at all with foreign goods, they must, before all things, be above suspicion for purity. In a war of 'wrinkles' we 
should go to the wall, and genuineness is our only strength. Bogus butter mixed with margarine, or bogus cheese made up with hog's lard, would kill the industry. So, too, if it is to compete with success, English butter must be well and uniformly made, carefully packed, and sent to market in attractive condition. Slovenly systems result in strong taste and low prices. These necessary elements have of late brought into prominence milk-factories and creameries. The danger of the system, unless it is conducted by and for farmers, is that it may establish another race of middlemen.

If tenant-farmers could but clear their exes of the dust of Protection, their outlook is by no means dismal. They enjoy a climate which is admirably adapted for diversitied farming; they have at their very doors an insatiable market; they command the best breeds of live animals; the diminished valne of agricultural produce is met by a corresponding fall in rents and the costs of production; labour is cheap, abundant, and, when good, the best in the world. They have before them examples, in every county, of men of their own class who have conquered circumstances, and who are at the present moment making money in their profession. All that is required is a frank recognition, both by landlords and tenants, of the changed conditions under which farming can be made to pay; on the one side, fair rents and proper homesteads for the manufacture of meat and dairy produce; on the other, revived energy, scientific practices, and more direct relations between producers and consumers. 


\section{CHAPTER XIX. \\ AGRICULTURAL LABOLRERS.}

STANDING as agricultural labourers do on the brink of pauperism, the slightest slip downwards carries them over the verge. But the most cheering symptom in rural distress at present, as contrasted with the past, is that hired labourer's have been the last, and not the first, to suffer by depression. Looking back to the period of protection from 1790 to 1840 , their condition was deplorable, a disgrace to civilisation generally, and to landlords and farmers in particular. Betreen 1770 and 1850 the average rent of arable land had more than doubled, while wages increased by one-eighth, the rent of cottages rose by a half, and the commons, by which the labourer had improved his income, were enclosed-rarely, indeed. without compensation, but generally without any permanent equivalent. The old Poor Law degraded peasants to parish pensioners, checked the circulation of labour, deteriorated its efficiency by fixing pay with reference to wants rather than services, encouraged the growth of a surplus population by rewarding the most productive couples. The standard of life from 1800 to 1834 sank to the lowest possible scale; in the South and West wages paid by employers fell to $3 s$. to $4 s$. per week, angmented by parochial relief from the pockets of those who had no need of labour ; and insufficient food has left its mark in 
the physical degeneracy of the peasantry. Herded together in cottages which, by their imperfect arrangements, violated every sanitary law, generated all kinds of disease, and rendered modesty an unimaginable thing; driven to a distance from their work in order to create model villages, and congregated in 'open' parishes, where they were subjected to the extortions of house-building speculators; compelled by insufficient wages to expose their wives to the degradation of field labour, and to send their children to work as soon as they could crawl-the peasant had little cause in the past to be enthusiastic for the land laws, the corn laws, and parochial relief. Disorganised by his divorce from the soil, demoralised by the poor law, degraded by insufficient money wages, lodged worse than the animals, oppressed by the high price of necessaries, the labourer would hare been more than human had he not risen in an insurrection which could only be quelled by force. He had already carried patience beyond the limit where it ceases to be a rirtue.

The relative improvement in the present condition of the agricultural labourer is enormons. Landlords have spared no pains to improve his moral and material position. Labonrers are comfortably lodged, and few are without land in the shape of field or cottage gardens; the agricultural gang, public or private, is at an end; fewer women and young children work in the fields; the abuses of the truck system have been reduced. They enjoy comforts to which twenty years ago they were strangers; they are better housed, better fed, better clad; their work is lighter, and their wages, tested by the purchasing power of money, higher than they liave been for centuries. But slow-witted as Hodge proverbially is, his memory is singularly tenacious. Deeply hidden in the recesses of 
his intricate mind lurk vague theories of lost rights, and more distinct traditions of past wrongs. He forgets that his present condition, in its substance, results from the natural operation of economic laws; he only remembers the occasions on which its unfortunate accidents have been aggravated for the benefit of landlords or of farmers.

Speaking generally, the worst aspects of peasant life at the present moment are the decreasing demands for agricultural labour, the absence of any reasonable prospect of emerging from the condition of hired service, and the pauper allowance which rewards the most industrious career. Some readjustment between the demand and supply for labour, some social ladder, and some better provision against old age are the true needs of the agricultural poor. So far from relieving the glut of labour, the new departure in the practice of farming will still further congest the market. Economical management and increased breadths of grass, whether permanent or temporary, mean a reduction of working expenses, which will take the form, not of less wages, but of less employment. Emigration affords the only outlet for the excess of the labour supply. But, putting this aside for the moment, do the agricultural changes which appear imminent afford no hope of partial remedy?

Everything points to a great reduction in the size of holdings, and closer relations between the labour and the land. Capital, in the shape of money, is being withdrawn from farming; large tenants are scarce, large farms hard to let. Capitalists worth from 5,000l. to $10,000 l$. will not invest in a trade which now means daily drudgery or pecuniary loss. Others, who have lost half their capital, would be glad to lose half their land, and desire to concentrate their money on narrower areas. Large farms go 
begging, when smaller holdings create competition. Thus the demand for land increases in extent as it diminishes in intensity; and the same fact has been already noted as the characteristic of social progress. " If agriculture for the time discards steam ploughs, it may find that spades are trumps. Easy-going farmers, bred in the traditions of cornlaw prices, are yielding to smaller men who, by sheer hard work, will force the land to pay.

Small peasant tenancies of 15 acres, in these days of small profits, offer a better chance of success than co-operative farms, where .Jack is as good as his master, and one idler drags down the rest. Small tenants, who make no outlay for labour, are indefatigable in their industry. If they soil their cattle, as every peasant does in France, they can keep three cows on land which, if grazed, would barely keep two. Calves, pigs, poultry, are within the reach of the humblest. Bigger men might also find breeding mares a profitable investment, especially if the Government provided good sires at easy rates. In France eggs are collected by cocotier's who travel the districts: a similar plan wonld enable the English peasant tenant to compete for a share in the 2,881,000l. which the country annually pays for foreign eggs. If a butter-making factory or a market for milk were at hand, his success would be as certain as anything can be in farming.

But the most industrious tenants require money capital with which to start. How is it to be provided? On the Continent the Prussian land-banks have proved useful agencies for the purpose. But, with the English dislike to State interference, 'caisses de crédit Raffeisen' may prove more popular. Societies of landlords form syndicates, and issue 3 per cent. bonds on the security of their

1 See page 160. 
land. The money thus raised is advanced to farmers at easy rates, from $3 \frac{1}{2}$ to 4 per cent. The system was started by M. Raffeisen in Neuwied on the Rhine, and, wherever it has spread, has proved successful. It is, however, essential that the circle within which each bank operates should be narrow, so that the members of the syndicate may be accurately informed of the position of wonld-be borrowers. ${ }^{1}$ One great feature of French agriculture cluring the recent depression is the increase of métayaye. Many agricultural writers admit that, on this system, landlords and tenants have got most from the land, and suffered least from falling prices; some have even called it the land system of the future. The theory of metayarge is admirable, and its working has been completely revolntionised since it was condemned by Arthur Young and Mill. Landlords and tenants combine to stock a farm; the tenant tills the soil, and manages the live stock under the direction of the landlord; the profits are divided as the interest on their respective capitals. Métayage applies co-operation directly and simply to agricultural industries; it forms an association of capital with labour, of practice with science; it brings to bear upon both partners the strongest motives of self-interest. It affords every variety of tenure, from the maître-valet who contributes nothing but his labour, or the personniers, companies of maitre-valets working under the

1 In some cases syndicates have been allowed to issue paper money against their cash in hand. The Prussian Land Bills of Exchange considerably increase powers of borrowing on real property. This negotiable mortgage (Grundschuld) may be made payable to order, and, if endorsed in blank, passes by mere delivery; and the holder for value can always enforce his claim against the estate. The power to transfer whenever the holder wishes increases the value of land as a security, and is easily obtained if a land registration system were once established in the country. 
supervision of their leader, the bourrat, to the metayen who brings $100 l$. into the partnership. ${ }^{1}$

It may, therefore, prove that, in the future, some large percentage of discharged labour will be settled on small holdings. On larger farms economies will take the form rather of reduced numbers than of reduced wages. The best men will probably be regularly employed at present rates; but nothing can, it is feared, secure permanent wages for industrious but unskilful labourers, still less for idle, drinking loafers, who are only servants on Saturday nights.

Different rates of wages have always existed, and may be illustrated from the scales fixed by justices of the peace in the serenteenth century. ${ }^{2}$ So, too, it was the habitual practice of farmers, at the commencement of the present century and previonsly to the general adoption of turnips and artificial grasses, to dismiss half their labourers in the winter months. The new and deplorable result of necessary changes in agricultural practices is not merely reduction of wages, or even temporary loss of work, but the sheer impossibility for a considerable section of the rural community to find work in the Old World.

There are, then, three classes of agricultmial labourers, who will be differently affected by the new departure which seems imminent: those who themselves settle on small holdings, those who find employment on large farms, and those who are discharged. If the tendencies of Eng-

1 For further details see 'Rural France,' Edinburgh Revien', October 1887, pp. 312-15.

1 E.g., in 1610, in Rutland, three classes of Iabourers are distirguished. 'A superior servant in husbandrie which can eire, sow, mow, thresh, make a rick, thacke and hedge the same, and can kill a sheep, hog, and calfe,' obtained $22.10 s$. a year with food; a common servant, $2 l$; a 'meane servant,' $1 l .9 s$. 
lish farming are rightly interpreted, the change will supply to the first two classes that social ladder, those means of making independent provision for old age, and that stimulus to energy, which their condition has litherto lacked. The marked deterioration in the quality of English labour is partly due to hopelessness, partly to the educational needs of the day, partly to want of varied experience. The first cause may be remored by the stimnlus afforded by small farms or allotments, by new sources of livelihood or new adjuncts to wages; the second may be mitigated by technical teaching in village schools; for the third it is perhaps hopeless to look for the extended revival of the bothy system of the north, which under a slightly different form prevailed at no distant period throughout the country. Farmers and their men once lived together and ate together; but the relations of the agricultural classes are altered. The reports of the Agricultural Commissions at the beginning of the century show that the practice of lodging and feeding farm servants died out because farmers' wires were 'too fine to keep house.' But such a practice benefits farmers, becanse, when prices are low, they need not sell large quantities of produce to realise money wages; and, in times of scarcity, labourers obtain a larger money value in the shape of food than they could buy for themselves. The farmer had constantly on the premises a large staff of labour: labour was more efficient; boys, boarded and lodged in farmhonses, learned all kinds of work, turned their hands, like Mr. Arch, to everything, and, like him, were perhaps worth $24 s$. a week to their emplojer. Above all, the system checked early and improrident marriages. The discomforts of a lodger in an overcrowded cottage blind the agricultural labonrer to all prudential considerations; he marries before he has time to save; for the next 
few years his life is an arduons struggle, which generally brings him on the parish. To the peasant the bothy system offers the same advantages which clubs afford to a different class. It enables him to wait in comfort till he has saved money. In some parts of France and in the north of England the hind's house is a frequent appendage to a farm. Labourers are hired for the year, and barracked on the spot in homesteads presided over by married labourers. They are better fed, and enjoy many comforts which they must forego when married. If such a system could be revived, labourers would not be driven to improvident marriages; they might save money before they start in life; they wonld be better trained to various kinds of work; they would acquire the money and the skill to make the most of allotments.

Sound policy and justice alike required that allotments should become universal. The most satisfactory and effective method of extending the system is the voluntary action of landlords; but to apathy or selfishness compulsion is rightly applied. Few cases remain in which the want is not supplied, and the question seems to be rapidly passing into an urban phase. ${ }^{1}$ The last session of Parliament, it may be added, secured compensation to allotment tenants for unexhausted improvements. Socially allotments stimulate thrift in early youth; they make labourers independent, train them to habits of industry, occupy their leisure, enable them to provide for old age. Agriculturally they counteract the prejudicial effects of education on the practical efficiency of labour by making boys and girls knowledgeable in agricultural matters; they prevent agricultural labour from migrating to the towns. Economically they occupy the leisure time of labourer's, and reclaim the 
drunkard, the idler, and the poacher; they relieve the rates, and, if a cow is kept, improve the health of the nation by supplying children with milk. Commercially they pay where the size is not too great to occupy more than the leisure time of the labourer, where the position is readily accessible, and where the rent is fair and paid direct to the landlord.

England and Wales, at the present moment, contain 807,608 agricultural labourers, farm servants, and cottagers. The table in Appendix XIV. shows that of this number 102,774 persons have potato-grounds or cow-runs; and that there are 387,574 field and 257,482 garden allotments. Thus more than three-fourths of the agricultural labourers occupy land in one form or another. The field allotments are for the most part conveniently placed, since, out of $387,000,318,000$ lie within half a mile of the cottages. A considerable number of those labourers who do not possess allotments are lodgers, or sons living at home with their parents. It is therefore strictly true that allotments are almost universal in rural districts.

The Table of Allotments has been drawn so as to show the districts in which they preponderate. It is intended for comparison with the Table of Wages, ${ }^{1}$ which has been similarly drawn. Comparatively few allotments exist in grazing districts, where wages are relatively high; they are most numerons in the corn counties, where wages are relatively low. 'It will be seen that the average weekly wages of agricultural labourers were estimated in 1771 by Arthur Young at $78.5 \frac{1}{2} d$. ; in 1824 they had risen to $9 s .7 \frac{1}{2} d$.; in 1881 , to $14 s .5 d$. Thus not only do labourer's enjoy better cottages than heretofore, as well as a system of allotments which is almost universal, but their nominal

I See Appendix XV., 'Agricultural Wages.' 
wages have risen within the last half-century by nearly five shillings. Nor is this all. It will be seen, from a glance at Appendix XVI.,' Table 2, that, within the last fifty years, their real wages have increased to an almost equal extent. Every item, except butter and butcher's meat, costs less, while the 4-1b. loaf has fallen from 1 s. 4 d. to $4 \frac{1}{2} d$. The condition of agricultural labourers may be, and ought to be, improved in directions already indicated, and it seems almost incredible that in the whole of England and Wales there should still be only 9,466 of the total number who have the opportunity of keeping a cow. But the advance which they have made in material prosperity is enormons, especially if it is remembered that their earnings, though primarily consisting of weekly wages, are largely supplemented by payments for task-work, piecework, and allowances; that, if employed at all, they are employed more continuously than in former times; and that though coal varies too widely in price in different districts to admit of any average being taken, yet not only firing, but all articles of clothing, are far cheaper in 1887 than in $182 \%$.

On the other hand, many articles of clothing which were formerly made at home are now bonght, and the very large additions to the weekly earnings of the family which were made by the wife and children are, to a great extent, withdrawn. Wages from 1871 to 1873 rose far higher than the figures shown in 1881, and further reductions have taken place within the last six years. But it seems probable that the average fall upon the wages of 1881 is not more than 1s. a week, and this loss is partially covered by the increased purchasing power of wages.

It is, then, evident that agricultmial labourers in full

${ }^{1}$ See Appendix XVI, Prices of Provisions, \&c. 
employment are, at the present moment, better off than any of the classes directly interested in agriculture. If small tenancies, as a consequence of the impending changes in farming, were placed within their reach, their prospects would be brighter than they have been for a century, their narrow horizon wider, their opportunity greater of rising in the social scale, their chance of independence better. The reverse of the picture is black. A large displacement of labour is imminent, which will further overstock the market. For this excess of supply there seems no remedy but emigration. The German labour colonies have succeeded among the unemployed, and their introduction into Russia has relieved the distress of the 180,000 peasant proprietors who in bad times have thrown up their holdings. ${ }^{1}$ But the system aims at little more than temporary relief; it affords no such prospects of permanent independence as are offered by State-directed colonisation, which plants well-assorted groups of emigrants on the vacant lands of our colonial empire. The Old World offers no adrantages comparable to those, for instance, of the village settlements of New Zealand. The Government sells land in small lots at $1 l$. the acre, or lets 20 acres for the same sum, and advances loans at $\check{5}$ per cent. to enable buyers or tenants to build houses or clear land. The colonies have the vacant land; England, the surplus population. The need of ontlet is urgent, and every day increases its pressure. Private enterprise cannot bring together colonial land and English labonr on a scale large

1 The first of these labour colonies (Arbeiter-Kolonic) was established in 1882 at Wilhelmsdorf in Westphalia. There are now (1887) sisteen, most of which are managed by 'House Fathers,' who are 'Brothers of the Inner Mission' trained at Hamburg and Berlin. A6 temporary expedients they are interesting, because successful, experiments. 
enough to prove effective. But private money would be, it is believed, subscribed in abundance if the Home Government framed, and negotiated with the colonies, a scheme to relieve that congestion of the labour markets which is the most pressing evil of the nineteenth century. 


\section{CHAPTER XX.}

\section{CONCLUSION.}

IT only remains to sum up the conclusions which have been formed.

The history of agriculture in this country traces the English system of land tenure to commercial or social exigencies which did not affect Continental nations. To these natural differences, rather than to artificial causes, is due the contrast in respect of land-ownership which England and the Continent present. What England lost in one direction she gained in another; she sacrificed the yeoman to the artisan.

Historically no substantial foundation exists for the cry that the English peasant proprietary was forcibly divorced from the soil. Still less does the history of any foreign country support the theory that the class can be created by the stroke of a pen. Nor can agricultural depression be attributed to our system of land-ownership. Whatever social and political advantages belong to a peasant proprietary, Continental experience shows that it is little less exposed to agricultural depression or foreign competition than the class of tenant farmers, and that its standard of farming can only be raised or maintained by a large outlay of public money, which in England is borne by private individuals.

The collapse of English agriculture must therefore be traced to other canses than conditions of land tenure. It 
commenced with inclement seasons, but it now springs from low prices arising out of foreign competition, cheap freights, over-production, and the increased purchasing power of gold. Where is the remedy to be sought?

Not in violent changes in conditions of land tenure; throughout the present crisis capitalist landlords have proved the saviours of the industry, and not an incubus on the soil. The pancity of their numbers slould add no element of insecurity to their property, but it narrowly limits the range of practicable measures for their relief. As a remedy for low prices Protection fails. Continental experience shows conclusively that moderate import duties do not enable wheat to be grown at a profit. Even if Protection offered a remedy, it is unlikely to be applied. For every one man who says that bread is too cheap, there are a hundred who say it is too dear. Nor, again, is the remedy to be found in the reduction of the tithe rentcharge. Apart from the injustice of the demand, those interested in its existing application, and those desirous of its diversion to secular objects, are united to preserve the corpus of the property intact. Moreover, subject to the life interest of the Church, inviolable so long as religion is recognised to be a vital element in the well-being of society, the nation claims the reversion; and therefore it is a prime duty of the State to guard the property with jealous care.

If, then, the remedy is not nationalisation of the land, nor Protection, nor the reduction of the tithe rent-charge, what is it? Some of the canses of agricultural depression may be met by legislation, others spring from natural conditions which cannot be controlled; others may be removed or modified by agriculturists themselves.

To the first class belong such remedies as the following. 
Land-law reform would increase the powers of life tenants to promote high farming, which hitherto has never enjoyed a fair chance of proving its capabilities. Increased facilities to transfer or charge land by the establishment of land registries would increase its value for sale or mortgage, and, even if they did not extend the number of proprietors, would remove all artificial hindrances to the natural growth of small owners. At present land lies so far beyond the general public that the masses have little respect for, or desire to guard, the sanctity of real property. Financial reform demands the readjustment of local taxation, which, as a burden on agricultural land, has lost its original justification, and now imposes Protection taxes on Free Trade prices. In this connection it may be suggested that since the dead capital, in the form of realised personalty, preys upon the living capital employed in industry, and since the fall of prices increases the value of the first in proportion as it diminishes the value of the second, a reduction of the interest upon the National Debt from 3 per cent. to $2 \frac{1}{2}$ is not inequitable, and would attract capital from consols to agricultural land by equalising the remunerative value of the investments. The extension of technical agricultural education, especially among labourers, and the efficient equipment of a Ministry of Agriculture, are so urgently needed as to be indispensable preliminaries to the successful growth of a peasant proprietary or a peasant tenancy. Finally, the present scale of differential railway charges excludes Euglish farmers from home markets. Higher rates upon local traffic than for long distances, and artificial competition between rival companies where land and sea carriage are not equally available and where time is essential, place premiums on distance at the expense of proximity, protect foreign producers, and offer bounties to 
remote markets by placing home growers at an actual disadvantage in respect of costs of conveyance.

No legislation can transform those elements of agricultural depression which depend on natural canses. So far as the currency affects the question, the increased prodnction of gold will, on the one side, diminish its purchasing power, and, on the other, restore its relative value to silver; while a decreased yield of the silver mines would deprive Indian corn producers of their advantages in the cost of production, and corn merchants of their speculations in rates of exchange. No other remedy, except the introduction of an international monetary standard, suggests itself for currency disturbances, though the issue of $1 l$. notes, payable to bearer on demand, might reduce the existing appreciation of gold, and, in the face of present prices, it might possibly prove good policy to suspend forced sales of silver on behalf of the Indian Government. Cheap freights immensely increase the stress of foreign competition. If trade revived, foreign goods would no longer arrive as ballast or for nominal charges, and hopeful signs are manifest that the long frost of commercial languor is breaking up. In the last quarter of 1887 everytling rose; pig iron, coal, copper, tin, lead, wheat, barley, oats, rice, beef, mutton, cotton, jute, petroleum-all realised better prices.

But though legislative aid may mitigate artificial hindrances to agricultural revival, and thongh one of the natural causes which intensify the stress of foreign competition appears to be passing away, self-help affords the best aid to agriculturists. Too many farmers slumber in their empty corn-bins, dreaming of Protection. If they cannot revise the fiscal system, they can at least revise their practical ideas. The reduction of the size of holding's 
and of the breadths of corn cultivation seems to indicate that the country stands on the edge of a revolution in farming practices, such as characterised the sixteenth and eighteenth centuries. Small farms are easier to let than large holdings, more suited to reduced capitals, better adapted to new requirements. Agriculture, if it is to pay, has become a daily drudgery, which men who are worth 5,000l. are indisposed to undergo. Such a reduction in the size of holdings harmonises with the laws of progress which have been observed as characteristics in society and other industries. Although large farmers with sufficient skill and capital to adopt the best practices of the highest farming may hold their own, the problem of low prices appears to be best met by economical management, minute attention to details, and constant personal supervision. Diversified farming, which concentrates its efforts on stock breeding, rearing, and fattening, and the production of fresh perishable articles of food, can be pursued with profit upon small holdings, whether farms of 250 acres, or peasant tenancies of fifteen acres where no outlay is made for wages. Prices have undoubtedly fallen; but land, labour, stock, and all the materials of farming have fallen in proportion. Every county can produce instances of enterprising men who regard foreign competition in wheat as a fixed quantity, accept the new conditions, and force the land to pay at present prices. Agricultural depression, in the strict sense of the word, is over for those who are not lured by the will-o'the-wisp of Protection deeper and further into the Slough of Despond.

If the change from tillage to pasture is unaccompanied by an exteusion of present holdings, the new departure which appears to be imminent must inevitably increase 
the amount of unemployed labour. If, on the other hand, it results in the multiplication of peasant holdings and in more direct relations between labour and land, a percentage of the displaced labour will become absorbed in small tenancies to the great advantage of rural society in general. Small farms supply those ladders of thrift, wider horizons, incentives to energy, and prospects of independence which are the great wants of their present condition. The best labourers may find employment upon the larger holdings. But for the rest, who are too unskilful or too numerous to secure permanent wages, the New World offers advantages for which the old affords no parallel. The crisis is indisputably grave; revolutionary legislation is powerfully advocated, and the position of landlords completely isolated. Agricultural labourers possess the franchise at a stage in their civilisation which renders them an easy prey to unscrupulous agitators. The fatal germs of the Irish Land Act of 1881 have already borne fruit in the demands of the Farmers' Alliance, and in the land bills which have been successively put forward by English, Scotch, and Welsh farmers. At the first gleam of agricultural prosperity the cry for tenantright will be renewed. Landlords have now the opportunity of removing legitimate grounds of discontent; of increasing the number of those who, as small occupiers, will be interested in the maintenance of landed interests; of reviving those cordial relations with their tenants which in times past made English agriculture the model and example for foreign nations; of striking from the hands of socialistic theorists weapons which are dangerous to the safety of society. The distinction between giving and giving up is vital. But here there is not even a question 
of giving. Changes such as are suggested entail no surrender of rights, no sacrifice of pecuniary interests. On the contrary, they are dictated to landlords not merely by political prudence, 'but by commercial selfinterest. 


\section{APPENDIX I.}

A TABLE SHOWING THE AVERAGE PRICE OF WHEAT PER QUARTER FROM 1043 TO 1886.

\begin{tabular}{|c|c|c|c|c|c|c|c|c|c|c|c|}
\hline $\begin{array}{c}\text { A.D. } \\
10 \pm 3\end{array}$ & . & $s$. & $\begin{array}{l}d . \\
0\end{array}$ & $\begin{array}{c}\text { A.D. } \\
1455\end{array}$ & . & $s$. & $\begin{array}{l}d . \\
2\end{array}$ & $\begin{array}{c}\text { A.D. } \\
16 \pm 9\end{array}$ & . & $\begin{array}{c}s . \\
\text {. }\end{array}$ & $\begin{array}{l}d . \\
0\end{array}$ \\
\hline 1125 & . & . 20 & 0 & 1460 & - & 8 & 0 & 1650 & . & . 76 & 8 \\
\hline 1196 & . & . 13 & 4 & 1463 & . & - 2 & 0 & 1651 & . & . 73 & 4 \\
\hline 1197 & . & . 18 & 8 & 1486 & . & . 24 & 0 & 1652 & . & . 49 & 6 \\
\hline 1237 & . & . 3 & 4 & 1491 & . & . 14 & 8 & 1653 & . & . 35 & 6 \\
\hline 1243 & . & 2 & 0 & 1494 & . & . $\quad t$ & 0 & 1654 & . & . 26 & 0 \\
\hline $12 \pm 6$ & . & . 16 & 0 & 1497 & . & . 20 & 0 & 1655 & . & . 33 & 4 \\
\hline 1257 & . & - 24 & 0 & 1499 & . & - 4 & 0 & 1656 & . & . 43 & 0 \\
\hline 1258 & . & . 16 & 0 & 1521 & . & . 20 & 0 & 1657 & - & . 46 & 8 \\
\hline 1270 & $96 s . t c$ & 128 & 0 & 1551 & . & - 8 & 0 & 1658 & . & . 65 & 0 \\
\hline 1286 & $2 s .8 d$. & & & 1557 & & 8 & 0 & 1659 & . & . 66 & 0 \\
\hline but & from : & & & Bef & Fre har & & & 1660 & . & . 56 & 6 \\
\hline storm & $m$ or & & & ve & st th & & & 1661 & . & . 70 & 0 \\
\hline July & $20 \mathrm{i}$ & it & & & ice ros & & & 1662 & . & . $7 \pm$ & 0 \\
\hline rose & to & 16 & 0 & to & . & 53 & 4 & 1663 & . & . 57 & 0 \\
\hline 1287 & . & 3 & $t$ & Aft & er har & & & $166 t$ & . & - 40 & 6 \\
\hline 1288 & . & 1 & 6 & & st it fel & & & 1665 & . & . 49 & 4 \\
\hline 1294 & . & 16 & 0 & to & . & 5 & 0 & 1666 & . & . 36 & 0 \\
\hline 1315 & . & 20 & 0 & 1574 & . & 56 & 0 & 1667 & . & 36 & 0 \\
\hline 1316 & . & 32 & 0 & Aft & er har & & & 1668 & . & . 40 & 0 \\
\hline 1317 & . & 44 & 0 & & st. & 21 & 0 & 1669 & 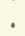 & . 44 & 4 \\
\hline 1336 & . & 2 & 0 & 1587 & . & . $\quad 64$ & 0 & 1670 & . & . 41 & 8 \\
\hline 1349 & . & 2 & 0 & 1594 & . & 56 & 0 & 1671 & . & . 42 & 0 \\
\hline 1359 & . & 26 & 8 & 1595 & . & 53 & 4 & 1672 & . & . 41 & 0 \\
\hline 1361 & . & 2 & 0 & 1596 & . & . 80 & 0 & 1673 & . & 46 & 8 \\
\hline 1363 & . & 15 & 0 & 1597 & $80 s$. to & 104 & 0 & 1674 & . & . $\quad 68$ & 8 \\
\hline 1379 & . & 4 & 0 & $16 \pm 1$ & . & . 57 & 1 & 1675 & . & . 64 & 8 \\
\hline 1387 & . & 2 & 0 & 1642 & . & . 60 & 2 & 1676 & . & . 38 & 0 \\
\hline 1390 & . & . 16 & 8 & 1643 & . & . 59 & 10 & 1677 & . & . 42 & 0 \\
\hline $1 \pm 01$ & . & 16 & 0 & 1644 & . & . 61 & 3 & 1678 & . & . 59 & 0 \\
\hline 1407 & . & 4 & 4 & 1645 & . & . 51 & 3 & 1679 & . & . 60 & 0 \\
\hline 1416 & . & 16 & 0 & 1646 & . & . 42 & 8 & 1680 & . & . 45 & 0 \\
\hline 1423 & - & 8 & 0 & 1647 & . & . 63 & 8 & 1681 & . & . 46 & 8 \\
\hline 1434 & . & 26 & 8 & $16 \pm 8$ & . & . 85 & 0 & 1682 & . & . 44 & 0 \\
\hline
\end{tabular}


Appendix I.-cont.

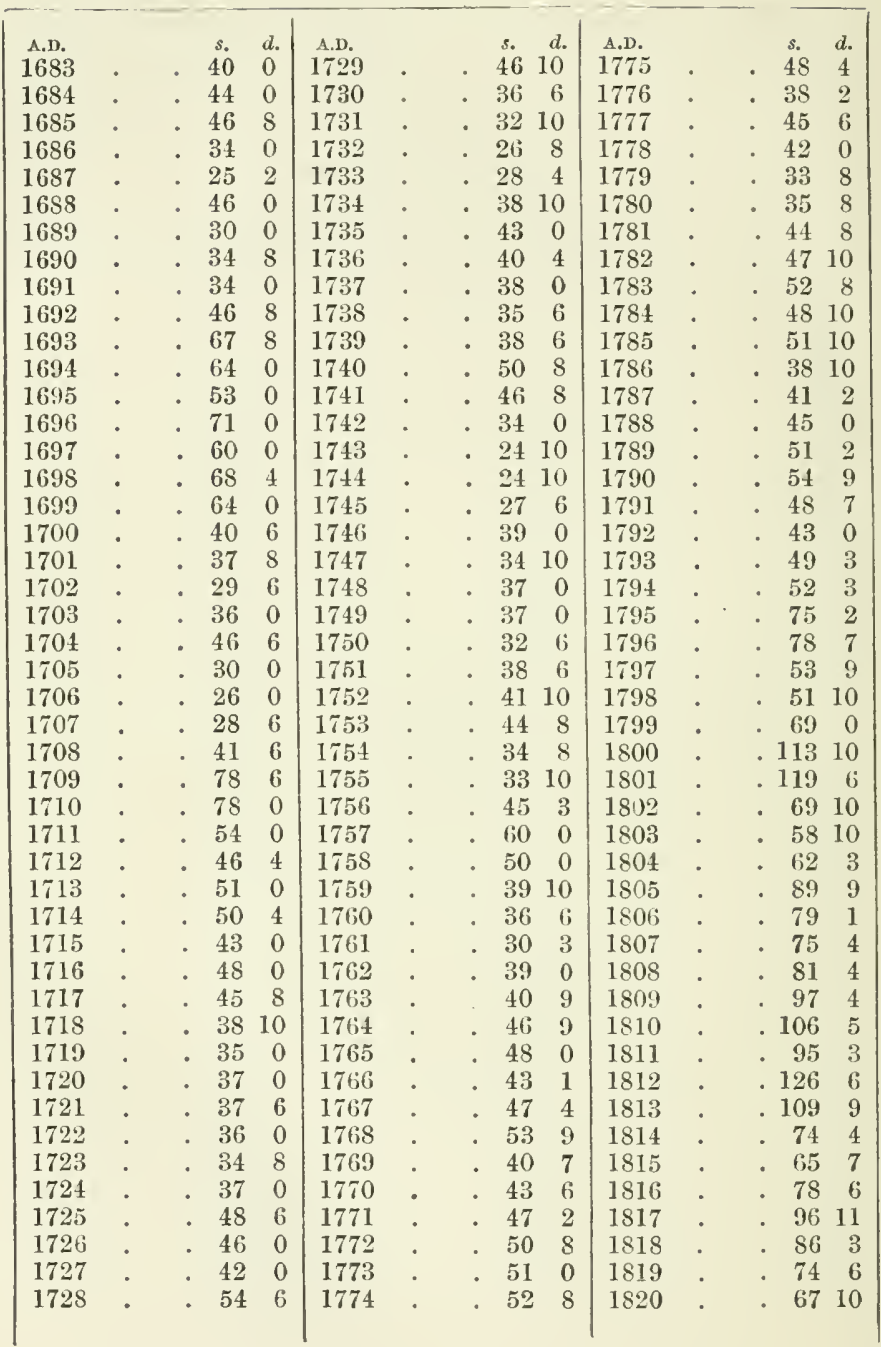


Appendix I.-cont

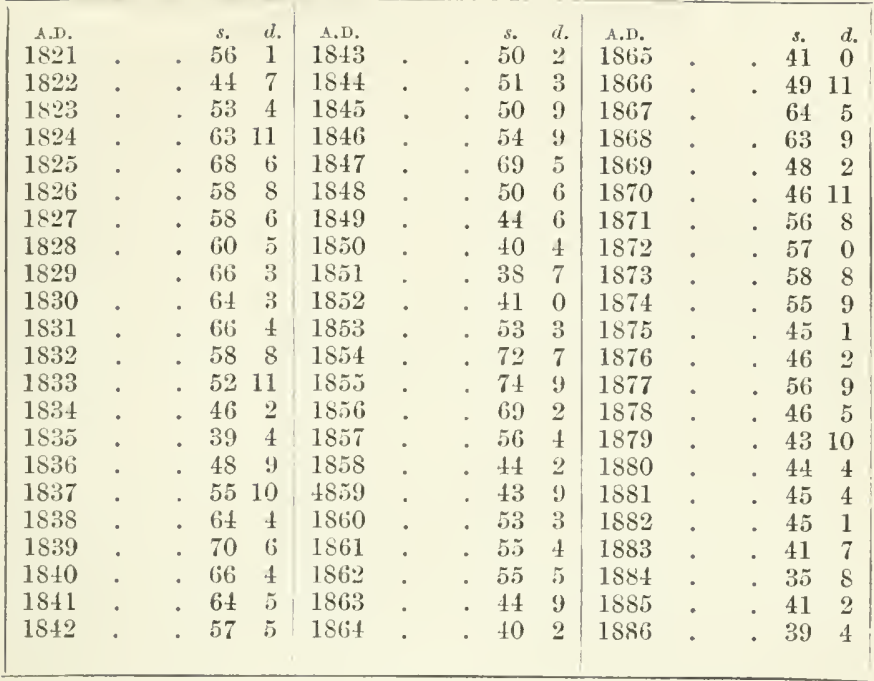

'The prices down to 1652 are taken from Fleetwood's Chronicon Pre. tiosum; from 1653 to 1764 from Charles Smith's Tracts on Corn Trade (edit.1804), pp. 125-7. These latter are unusually high, as they represent the prices of the best, and not the middling, wheat. 


\section{APPENDIX II.}

LEGISLATION AGAINT PASTURE FARMS ON SOCIAL GROUNDS.

(a) In the 4th year of Henry VII. an Act was passed relating to the Isle of Wight, to prevent the mischief arising from throwing small holdings into one large farm. The Preamble recites :-

'Forasmuch as it is to the king, \&c., great surety, and also the surety of this realm of England, that the Isle of Wight be well inlabited with English people, \&c., the which isle is lately decayed of people, by reason that many towns and villages have been beaten down, and the Fields ditched, dc., and many dwelling-places, ferms, and ferm-holds taken into one man's hands, that of old time were wont to be in many several persons holds and hands, and many several households kept in them, and thereby much people multiplied, and the same isle thereby well inhabited; the which now, by the occasion aforesaid, is desolate, and not inhabited, but occupied with beasts and cattle; so that if hasty remedy be not provided, that isle cannot be kept and defended, but will be open and ready to the king's enemies, which God forbid :-For remedy whereof it is ordained,' \&c.

(b) 4 Henry VII. c. 19 is more general. The Preamble recites as follows:-

'The king our sovereign lord having a singular pleasure above all things to avoid such enormities and mischiefs as be hurtful and prejudicial to the common weal of this liis land, and his subjects of the same, remembereth that among other things great inconveniences daily do increase by desolation, and pulling down, and wilful waste of houses within this 
realm, and laying to pasture what customably have been used in tillage; whereby idleness, which is the ground and beginning of all mischiefs, daily doth increase. For where in some towns two hundred persons were occupied and lived of their lawful labours, now there are occupied two or three herdsmen, and the residue fall into idleness, that husbandrie, which is one of the greatest commodities of this realm, is greatly decayed, churches destroyed, the service of God withdrawn, the bodies there buried not prayed for, the patrons and curates wronged, the defence of this land, against our enemies outward, feebled and impaired, to the great displeasure of God, to the subversion of the policy and good rule of this land if remedy be not provided,' itc., \&c. 


\section{APPENDIX III.}

AGRICULTURAL WRITERS OF THE $16 \mathrm{TH}, 17 \mathrm{TH}$, AND FIRST HALF OF THE 18Th CENTURIES.

The principal agricultural writers of England and Wales from 1500 to 1740 are given in the following list; but the list does not pretend to be exhaustive, nor are the editions to which the dates are affixed in all cases the first.

1523. Fitzherbert (Sir Anthony) One of the Justices of the Court of Common Pleas.

1. Boke of Surveyeng. 1523, 4 to.

2. Boke of Husbandry. 1525, 4to.

1537. De Benese (Sir Richard)

This Boke sheweth the maner of measurynge of all maner of land. Southwarke, 1537.

1573. Tusser (Thomas)

Five hundredth points of good husbandry. London, 1573, 4to.

1574. Scot (Reginald)

A perfite platforme of a Hoppe Garden and necessarie instructions for the making and mayntenaunce thereof. London, 1574, 4 to.

[This is the first treatise upon hops.]

1594. Plat, or Platt (Sir Hugh)

The Jewell House of Art and Nature. London, 1594 , Svo.

1605. Mascall (Leonard)

The Government of Cattell.

Part I. The Govermment of oxen.

Part II. The Government of horses.

Part III. The ordering of sheep.

Loncton, 1605, 4to. 
1607. Norden (Jolnn)

The Surveyor's Dialogue. London, 1607, 8vo. de., \&c.

1610. Vaughan (Rowland)

Most approved and longexperienced Water Workes.

Containing the manner of Winter and Summer drowning of Medow \& pasture. London, 1610, 4 to. [This is the first treatise on irrigation.]

1614. Markham (Gervase)

1. The English Husbandman. London, 1614.

2. Countrey Contentments, 2 parts. London, 1615 , 4 to.

3. A Way to get Wealth, 6 parts. London, 1638.

4. Complete Farriar. London, 1639, Svo.

1639. Plattes (Gabriel)

$$
\text { dre, \&c. }
$$

A discovery of Subterraneal Treasure.

(Not Agricultural but Mineral Works.) London, 1639 , 4 to.

1649. Blith (Walter)

The English Improver ; or, A new survey of husbandry. London, 1649, 4to.

[This is the first explanation of the science of drainage.] 1650. Weston (Sir Richard)

A Discourse of Husbandrie used in Brabant and Flanders. (Edited by S. Hartlib.) London, 1650,4 to.

[This is the first attempt to explain the cultivation of turnips.]

1650. Hartlib (Samuel)

1. A discourse of Hushandrie used in Brabant and Flanders. London, 1650, 4 to.

2. Samuel Hartlib his Legacie ; or an enlargement of the Discourse of Husbandry. London, 1651, 4 to.

3. A Design for plentie by an universall planting of fruit-trees. London, 1652, 4 to.

4. The Compleat Husbandman. London, 1659, 4 to. \&c., de. 
1656. Lee (Josepli) Rev.

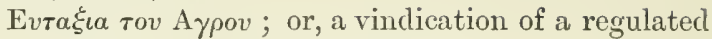
inclosure. London, 1656, 4 to.

1659. Speed (Adolphus)

Adam out of Eden, or an abstract of clivers excel-

lent experiments touching the advancement of Husbandry. London, 1659, Sro.

1661. Stevenson (Matthew)

The Twelve Moneths; or, a discourse of every action proper to each particular moneth. London, 1661, 4to.

1662. Miles (Abraham)

The Countryman's Friend and no ... Mountebank, but a rare method of Chirurgery and physick. London, 166.), Sro.

1664. Forster (John), of Hanslop, Bucks.

England's Happiness increased; or a sure and easie remedy against all succeeding dear years; by a plantation of the roots called potatoes. London, 1664, 4to.

[This is the first treatise upon potatoes. The cultivation of the root was practically little known till the end of the eighteenth century, when it was zealously advocated by the Board of Agriculture.]

1669. Worlidge (John)

Systema Agriculture; the mystery of husbandry discovered. London, 1669, fol.

1670. Reeve (Gabriel)

Directions left by a gentleman to his sons for the improvenent of barren and heathy land in England and Wales. London, 1670, 4to.

1673. Smith (John) Captain, late a London merchant. England's Improvement revis'd in a Treatise of all manner of Husbandry and Trade by Land and Sea. London, 1673, 4 to.

1677. Yarranton (Andrew)

England's improvement by sea and land, 2 parts. London, 1677-81, 4to. 
1681. Houghton (John), F.P.S'

1. A Collection of Letters for the improvement of Husbandry and Trade. London, 1681-3, 4 to.

2. An Account of the Acres and Houses with the Proportional Tax, dc., of each county in England and Wales. London, 1693, s. sh. fol.

1685. Moore (Sir Jonas)

1. History of the Great Level of the Fennes. London, 1685, Sro.

2. England's Interest, or the Gentleman and Farmer's friend, 2nd edition. London, 1703, 12mo.

1697. Meager (Leonard)

The Mystery of Husbandry ; or, arable pasture and wood-land improved. To which is added the Countryman's Almanack. London, 1697, 12 mo.

1708. Mortimer (John)

The Whole Art of Husbandry, 2 parts. London, 1708 , svo.

1717. Jacob (Giles)

The Country Gentleman's Vade Mecum. London, $1717,12 \mathrm{mo}$.

1724. Bradley (Richard)

1. A treatise concerning the manner of fallowing ground. 172t, Svo.

2. A collection for the improvement of husbandry. 1727,8 vo.

3. A complete book of husbandry, \&c. 1727, 8vo.

1731. Tull (Jethro), of Shalborn, near Hungerford, in Berkshire, was a man of great inventive genius as well as scientific attainments. He advocated deep cultivation, drilling seed, small sowings, hoeing turnips. He also invented a variety of implements, such as ploughs, hoes, drills, de.

The new horse-houghing husbandry. 1731, 4to.

1731. Ellis (William), of Little Gaddesden, Hertfordshire.

1. The Practical Farmer. London, 1731, Svo.

2. Chilton and Vale Farming. London, 1733, Svo.

3. A complete system of Improvements. London, 1749, sro.

$$
\text { \&c., Ec. }
$$




\section{APPENDIX IV.}

\section{THE CORN LAWS.}

Tre Enghsh corn laws at different times aimed at three prin. cipal objects :-(1) Abundance and low profits. (2) Revenue. (3) Encouragement of tillage and agriculture by raising prices to an artificial height.

(1) The first object was secured by absolute prohibition of exportation, which was the policy of the Legislature from the Norman Conquest to 1329 , or by compulsory sales of produce for what it would fetch at the nearest market, and laws directed against engrossers or corn-dealers.

The first object was gradually exchanged for the third, and the necessity of maintaining the rural population ${ }^{1}$ or strengthening the navy forms the transition stage between the prohibition of exports and protection. The laws against engrossing, \&c., were modified in 1663, when intemal corndealing was permitted, and repealed in 1773 .

(2) The second object governed the legislation of 1660 , but was speedily abandoned.

(3) Encouragement of tillage and agriculture was the object of the Legislature, with certain exceptions, from the fourteenth to the nineteenth century.

The following are the principal Acts relating to corn :-

\begin{tabular}{|c|c|c|c|}
\hline Year & Statute & Provisions & $\begin{array}{c}\text { Price of } \\
\text { Wheat at date }\end{array}$ \\
\hline 1323 & $\begin{array}{l}17 \text { Ed. II. } \\
\text { c. } 3\end{array}$ & $\begin{array}{l}\text { Permitting importation of corn from } \\
\text { Ireland into England. }\end{array}$ & $\begin{array}{ll}\text { s. } & d . \\
7 & 5 \frac{3}{8}\end{array}$ \\
\hline 1329 & 3 Ed. III. & $\begin{array}{l}\text { Prohibiting importations of corn into } \\
\text { England unless the prices of a quar- } \\
\text { ter of wheat, rye, or barley exceeded } \\
\text { respectively } 6 s .8 d ., 4 s \text {, and } 3 s \text {. }\end{array}$ & $6 \quad 6 \frac{5}{8}$ \\
\hline
\end{tabular}


Appendix IV.-cont.

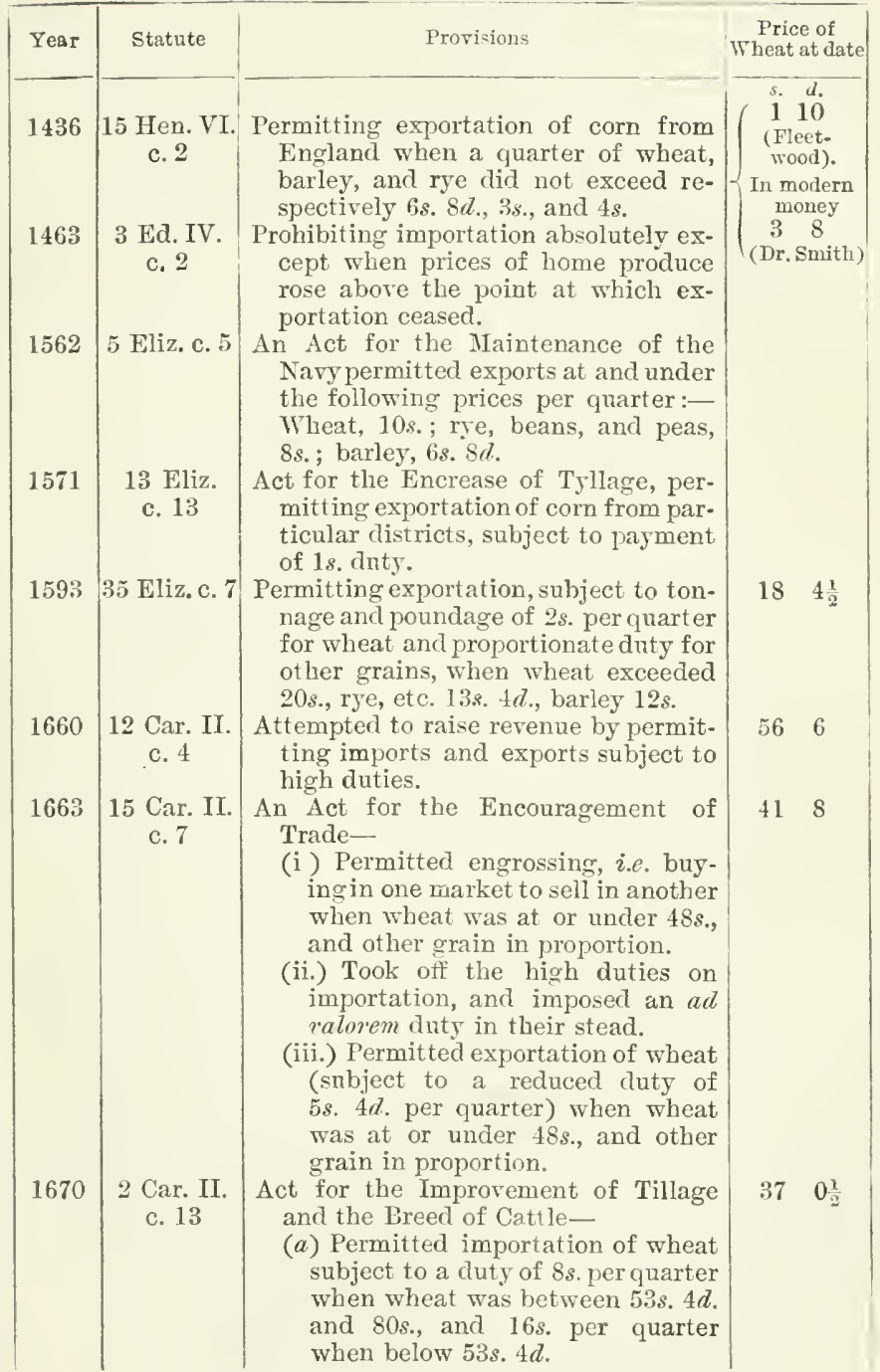


Appendix IV.-cont.

\begin{tabular}{|c|c|c|c|c|}
\hline Year & Statute & Provisions & $\begin{array}{l}\text { Pric } \\
\text { Wheat }\end{array}$ & $\begin{array}{l}e \text { of } \\
\text { at date }\end{array}$ \\
\hline 1670 & $\begin{array}{l}2 \text { Car. II. } \\
\text { c. } 13\end{array}$ & $\begin{array}{l}\text { (b) Prohibited exportation when the } \\
\text { lome price of wheat was } 53 s .4 d \text {. } \\
\text { or above it. Other grain in pro- } \\
\text { portion. }\end{array}$ & s. & $d$. \\
\hline $168^{\prime}$ & $\begin{array}{l}1 \mathrm{Wm} . \& \\
\text { Iary, c. } 12\end{array}$ & 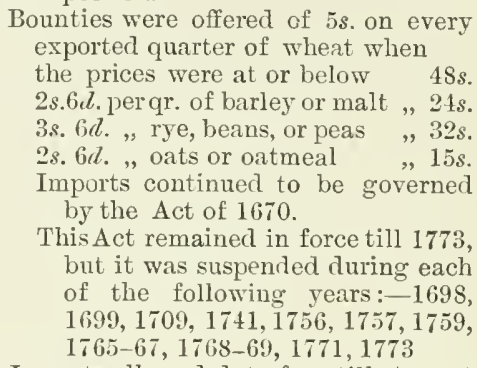 & 46 & 8 \\
\hline 1757 & $\begin{array}{c}30 \text { Geo. II. } \\
\text { c. } 7\end{array}$ & $\begin{array}{l}\text { Imports allowed duty free till August } \\
25,1757 \text {. }\end{array}$ & 60 & 0 \\
\hline 1766 & $\begin{array}{l}6 \text { Geo. III. } \\
\text { c. } 3 \& 4\end{array}$ & $\begin{array}{l}\text { Permitted importation of wheat, oats, } \\
\text { and oatmeal from America duty free } \\
\text { up to Michaelmas in that year. }\end{array}$ & 43 & 1 \\
\hline 1773 & $\begin{array}{l}13 \text { Geo. III. } \\
\text { c. } 43\end{array}$ & $\begin{array}{l}\text { Burke's Act- } \\
\text { (1) Prohibited exports and abolished } \\
\text { the bounty when the quarter of } \\
\text { wheat was at or abore } 44 s \text {, of rye } \\
28 s \text {, of barley } 32 s \text {, of oats } 14 s \text {. }\end{array}$ & 51 & 0 \\
\hline
\end{tabular}

1 Bounties paid upon Eirports of Corn under 1 William \& Mary from $1697-1765$.

\begin{tabular}{|c|c|c|c|c|c|c|c|c|}
\hline Years & Wheat & Barley & Malt & Oatmeal & Rye & $\begin{array}{r}\text { Amount of } \\
\text { ties }\end{array}$ & Bour & \\
\hline $\begin{array}{l}1697-1706 \\
1706-1726 \\
1726-1746 \\
17 \pm 6-1765\end{array}$ & $\begin{array}{r}\text { Quarters } \\
552,867 \\
2,518,213 \\
4,461,337 \\
6,800,017\end{array}$ & $\begin{array}{r}\text { Quarters } \\
251,689 \\
433,237 \\
590,080 \\
1,268,080\end{array}$ & $\begin{array}{r}\text { Quarters } \\
623,345 \\
4,381,205 \\
3,871,332 \\
4,777,303\end{array}$ & $\begin{array}{c}\text { Quarters } \\
2,015 \\
11,922 \\
45,932 \\
67,186\end{array}$ & $\begin{array}{r}\text { Quarters } \\
238,985 \\
789,618 \\
520,020 \\
939,580\end{array}$ & $\begin{array}{c}\mathcal{E} \\
289,670 \\
1,371,032 \\
1,769.756 \\
2,628,503\end{array}$ & $\begin{array}{r}s . \\
14 \\
4 \\
4 \\
4\end{array}$ & $\begin{array}{r}d . \\
0 \\
0 \\
2 \\
7\end{array}$ \\
\hline $1697-1765$ & $14,332,435$ & $2,543,096$ & $13,653,186$ & 127,056 & $2,488,206$ & $£ 6,058,962$ & 6 & 9 \\
\hline
\end{tabular}

Between 1765 and 1773 the law was almost continnously suspended. In 1773 Burke's Act was passed. In the next twenty-six years the imports of wheat (aud of other grain in proportion) exceedel the exports. The following table shows the gradual decline of our export trade :-

1765-7:4 imports of wheat exceeded exports by 830,619 quarters

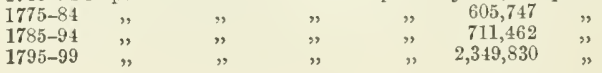


Appendix IV.-cont.

\begin{tabular}{|c|c|c|c|c|}
\hline Year & Statute & Provisions. & $\begin{array}{c}\text { Price } \\
\text { Wheat at }\end{array}$ & $\begin{array}{l}\text { of } \\
\text { t date }\end{array}$ \\
\hline 1773 & $\begin{array}{c}13 \text { Geo. III. } \\
\text { c. } 13\end{array}$ & $\begin{array}{l}\text { (2) Permitted exports and continued } \\
\text { the bounty when prices were below } \\
\text { the above limits. } \\
\text { (3) Permitted imports of foreign } \\
\text { grain at a duty of } 6 a \text {. a quarter } \\
\text { when home-grown wheat was at } \\
\text { or above } 48 s \text {, and other grain in } \\
\text { proportion. } \\
\text { (4) Imposed the prohibitory duties } \\
\text { of } 12 \text { Car. II. upon foreign pro- } \\
\text { duce imported below those prices. } \\
\text { (5) Allowed foreign corn to be im- } \\
\text { ported duty free for exportation. }\end{array}$ & s. $d$ & \\
\hline 1791 & $\begin{array}{l}31 \text { Geo. III. } \\
\text { c. } 30\end{array}$ & $\begin{array}{l}\text { (1) Rearranged the scale of duties on } \\
\text { imports, } 6 a \text {. a quarter on wheat at } \\
\text { or above } 54 s . \text {. } 2 s .6 d \text {. between } 54 s \text {. } \\
\text { and } 50 s ., 24 s .3 d \text {. below } 50 s \text {. } \\
\text { (2) Pelmitted wheat to be exported } \\
\text { up to } 46 s \text {. without bounty, and up to } \\
44 s \text {. with bounty. } \\
\text { (3) Provided proper registration of } \\
\text { prices of grain. }\end{array}$ & 48 & 7 \\
\hline 1804 & $\begin{array}{l}14 \text { Geo. III. } \\
\text { c. } 53\end{array}$ & $\begin{array}{l}\text { Imposed higher duties on foreign im. } \\
\text { ports, } 6 d \text {. a quarter when home prices } \\
\text { were at or above } 66 s ., 2 s \text {. } 6 d \text {. be- } \\
\text { tween } 66 s \text {. and } 63 s ., 24 s .3 d \text {. below } \\
63 s \text {. It also permitted exports up } \\
\text { to } 54 s \text {. }\end{array}$ & 62 & 3 \\
\hline 1806 & $\begin{array}{l}16 \text { Geo. III. } \\
\text { c. } 97\end{array}$ & $\begin{array}{l}\text { Free export and import of corn per- } \\
\text { mitted between Great Britain and } \\
\text { Ireland. }\end{array}$ & 79 & 1 \\
\hline 1813 & $\begin{array}{l}53 \text { Geo. III. } \\
\text { c. } 33\end{array}$ & $\begin{array}{l}\text { The bounty was discontinued and un- } \\
\text { restricted freedom of exportation } \\
\text { allowed. Importation was permitted } \\
\text { at the following duties for wheat :- } \\
\text { Is. a quarter at or above } 80 s \text {, and } \\
\text { an increasing duty, with decreasing } \\
\text { prices, till the duty on wheat im- } \\
\text { ported at } 64 s .=24 s \text {. }\end{array}$ & 109 & 9 \\
\hline 1815 & $\begin{array}{l}55 \mathrm{Geo} \text {. III. } \\
\text { c. } 26\end{array}$ & $\begin{array}{l}\text { Mr. Robinson's Act, only passed under } \\
\text { a protest from ten Peers, entered on } \\
\text { the Journals of the House, pro- } \\
\text { hibited the importation of foreign } \\
\text { wheat till home prices stood at the } \\
\text { following figures per quarter :- } \\
\text { Wheat, } 80 s . \text {; barley, } 40 s \text {. ; oats, } 26 s . \text {; }\end{array}$ & 65 & 7 \\
\hline
\end{tabular}


Appendix IV.-cont.

\begin{tabular}{|c|c|c|c|c|}
\hline Year & Statute & Provisions & $\begin{array}{r}\text { Price } \\
\text { Wheat a }\end{array}$ & of \\
\hline 1815 & $\begin{array}{c}55 \text { Geo. III. } \\
\text { c. } 26\end{array}$ & $\begin{array}{l}\text { rye, beans, and peas, } 53 s \text {. British } \\
\text { North American corn was admitted } \\
\text { on a lower scale. }\end{array}$ & s. & \\
\hline 1822 & $\begin{array}{l}3 \mathrm{Geo} . \mathrm{IV} . \\
\text { c. } 60\end{array}$ & $\begin{array}{l}\text { Another scale was fixed which was to } \\
\text { come into force so soon as the limits } \\
\text { stated by the Act of } 1815 \text { had been } \\
\text { reached. Nominally a concession, } \\
\text { the new Act increased Protection by } \\
\text { loading corn with additional duties } \\
\text { for the first three months after } \\
\text { opening the ports. }\end{array}$ & 44 & 7 \\
\hline 1825 & & $\begin{array}{l}\text { The home crop was so deficient that } \\
\text { foreign wheat was admitted, irre- } \\
\text { spective of home prices, at a duty of } \\
\text { 5s. per quarter. }\end{array}$ & $6 \mathrm{~S}$ & \\
\hline 1826 & & $\begin{array}{l}\text { Foreign rye and oats were admitted at } \\
\text { nominal prices. }\end{array}$ & 58 & 8 \\
\hline 1829 & $\begin{array}{l}9 \text { Geo. IV. } \\
\text { c. } 60\end{array}$ & 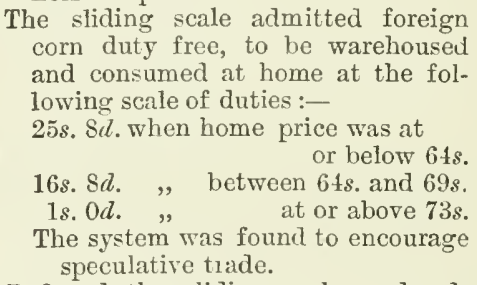 & 66 & 3 \\
\hline $18+2$ & 5 Vict. c. 14 & $\begin{array}{l}\text { Reduced the sliding scale, and ad- } \\
\text { mitted cattle and fresh provisions } \\
\text { to be imported from abroad. }\end{array}$ & 57 & 5 \\
\hline 1843 & $\begin{array}{l}6 \text { \& } 7 \text { Vict. } \\
\text { c. } 29\end{array}$ & $\begin{array}{l}\text { Reduced the duties on Canadian wheat } \\
\text { to } 1 \text { s. a quarter. }\end{array}$ & 50 & 2 \\
\hline 1816 & $\begin{array}{l}9 \text { s } 10 \text { Vict. } \\
\text { c. } 22\end{array}$ & $\begin{array}{l}\text { On and after February } 1,1849 \text {, foreign } \\
\text { corn was admitted on the following } \\
\text { scale:- } \\
\text { (a) Wheat, barley, oats, rye, beans, } \\
\text { peas, } 1 s \text {. per quarter. } \\
\text { (b) For meal of any of the same, } \\
4 \frac{1}{2} \ell \text {. per cwt. }\end{array}$ & 54 & 9 \\
\hline 1869 & $\begin{array}{l}32 \text { Vict. } \\
\text { c. } 14, \text { s. } 4\end{array}$ & $\begin{array}{l}\text { Abolished these duties, which were in } \\
\text { the nature of registration fees. }\end{array}$ & 48 & 2 \\
\hline
\end{tabular}




\section{APPENDIX V.}

\section{ENCLOSL'RES.}

THE number of acres enclosed since 1700 probably exceeds $8 \frac{1}{4}$ millions. The progress of the movement is shown below.

\begin{tabular}{|c|c|c|c|c|c|c|c|}
\hline \multicolumn{6}{|c|}{ Reign or Date } & \multirow{2}{*}{$\frac{\text { No. of Bills }}{3}$} & \multirow{2}{*}{$\frac{\text { Acreage }}{1,439}$} \\
\hline Anne & • & . & . & . & . & & \\
\hline George I & & . & . & . & . & 16 & 17,960 \\
\hline George I & II. & . & . & . & . & 226 & 318,778 \\
\hline \multicolumn{8}{|c|}{ George III. - } \\
\hline (a) 17 & 760 & & . & . & . & 1,482 & $2,980,000$ \\
\hline (b) 17 & $797-$ & 810 & . & . & . & 956 & $1,897,980$ \\
\hline (c) 18 & 810 & & . & . & . & 771 & $1,410,930$ \\
\hline $1820-30$ & . & . & . & . & . & 186 & 340,380 \\
\hline $1830-40$ & . & . & . & . & . & 129 & 236,070 \\
\hline $1840-50$ & . & . & . & . & . & 66 & 369,127 \\
\hline $1850-86$ & . & . & . & . & . & - & abont 800,000 \\
\hline \multicolumn{4}{|c|}{ Total, 186 years } & . & . & 3,835 & $8,372,662$ \\
\hline
\end{tabular}

The decline in the number of enclosures is apparently arrested in 1840-50 ; but 270,000 acres out of the total enclosed in that decade of years were enclosed under the General Act of $18+5$.

The agricultural statistics from 1866 to 1886 show an apparently large increase in acreage; but this is mainly due to fuller and more correct returns. It is also to be noticed that the area of agricultural land is being constantly diminished by the growth of towns, the increase of railways, roads, \&c.

More than three-fourths of the total enclosures $\{6,288,910$ acres) were made in the reign of George III. 


\section{APPENDIX VI.}

QUESTIONS ATTACHED TO THE CIRCULAR LETTER OF THE BOARD OF AGRICULTURE (FEBRUARY 13, 1816).

1. ARE any farms in your neighbourhood unoccupied by tenants; and have landlords, in consequence, been obliged to take them into their own hands? Please to state the number of farms, and their size.

2. Have any tenants, within your knowledge, given notice to their landlords of quitting their farms at Lady-day, or any other period?

3. Have any farms been lately relet at an abatemont of rent; and if so, what is the proportion of such abatement?

4. What circumstances, denoting the distress of the farmers, liave come to your knowledge, which may not be included under the above queries ?

5. Is the present distress greater on arable or on grass farms?

6. Have flock farms suffered equally with others?

7. Does the country in which you reside suffer from a diminished circulation of paper?

8. What is the state of the labouring poor ; and what is the proportion of poor rates compared with the years 1811 and 1812 ?

9. What remedies occur to you for alleviating these diffculties ? 


\begin{tabular}{|c|c|c|c|c|c|}
\hline 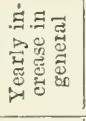 & 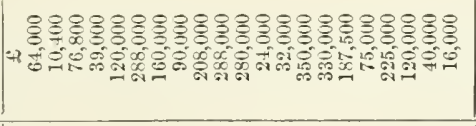 & 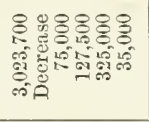 & 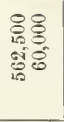 & 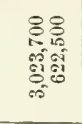 & 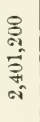 \\
\hline 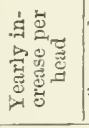 & 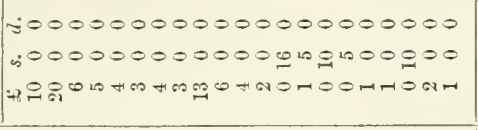 & 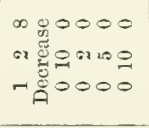 & $\begin{array}{l}\infty \\
00 \\
00\end{array}$ & $\begin{array}{l}-\infty \\
\infty\end{array}$ & $\infty$ \\
\hline 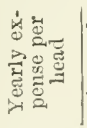 & 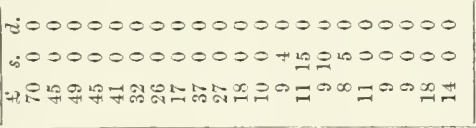 & $\begin{array}{l}\Rightarrow 0000 \\
=0020 \\
=\pi+1\end{array}$ & $\begin{array}{l}\infty \\
\infty \\
\infty\end{array}$ & $=$ & $\infty$ \\
\hline 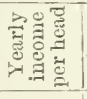 & 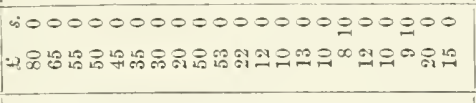 & $\begin{array}{l}\infty 0000 \\
\rightarrow \text { ntan }\end{array}$ & 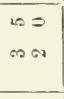 & 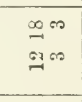 & $\stackrel{\infty}{n}$ \\
\hline 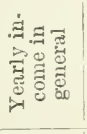 & 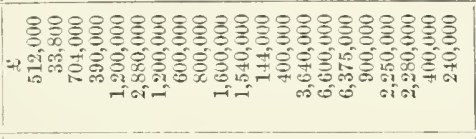 & 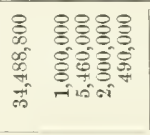 & 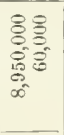 & 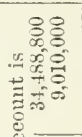 & 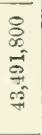 \\
\hline 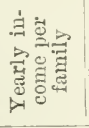 & 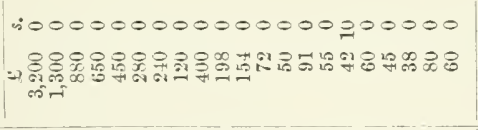 & $\begin{array}{l}\infty \quad 0000 \\
\infty \quad 820=1\end{array}$ & $\stackrel{\varrho}{\varrho}$ & 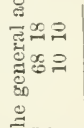 & 28 \\
\hline 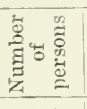 & 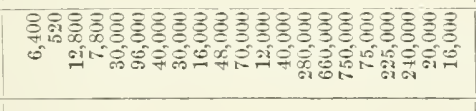 & 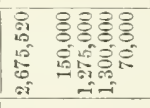 & 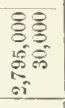 & 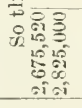 & 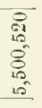 \\
\hline 总 & 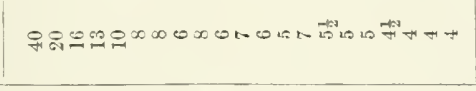 & $2 \pi \cos 6 \cos ^{-10 x}$ & ${ }_{00}^{-1+}$ & 2000 & +1 \\
\hline 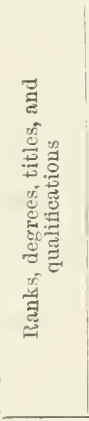 & 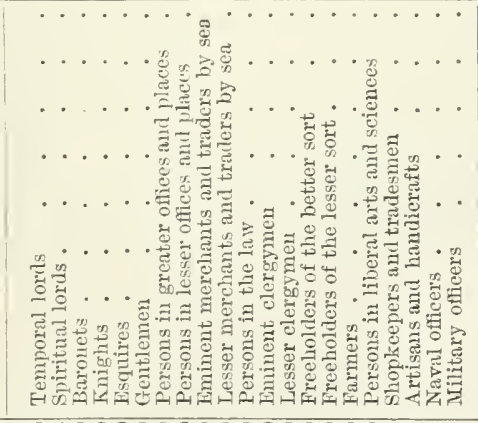 & 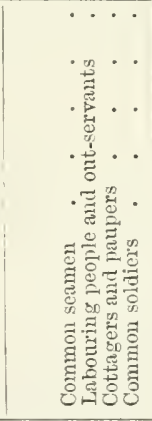 & 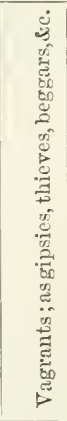 & 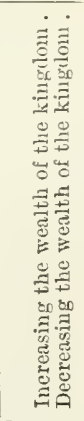 & 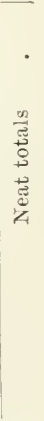 \\
\hline 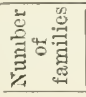 & 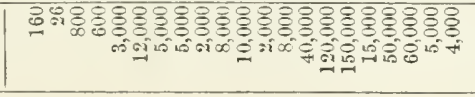 & 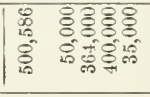 & $\begin{array}{l}8 \\
8 \\
0 \\
0 \\
0\end{array}$ & $\begin{array}{l}\infty 08 \\
108 \\
80 \\
80 \\
10\end{array}$ & $\begin{array}{l}\infty \\
\infty \\
10 \\
0 \\
0 \\
-1 \\
-1\end{array}$ \\
\hline
\end{tabular}


TABLE 2.-Numbers and Occupations of those who were engaged in Agriculture in England and Wales in 1851, 1861, 1871, and 1881.

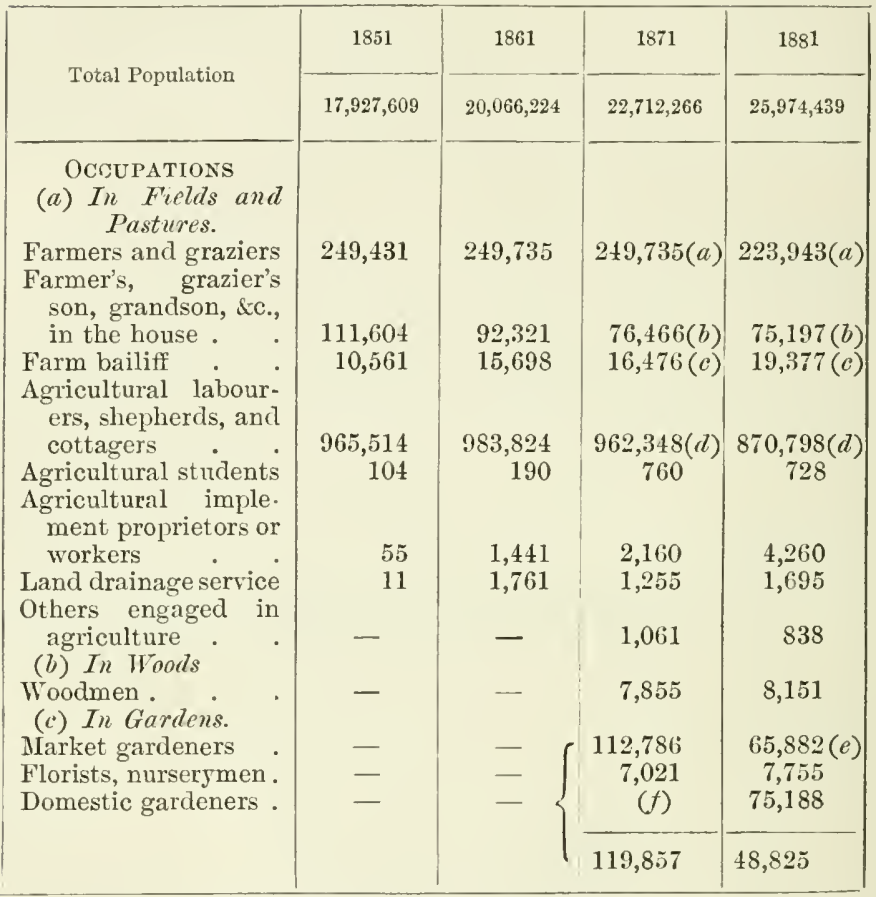

(a) Shows reduction of 25,964 in number of farmers, or 10 per cent.

(b) Shows a decline in the number of those who, having no other definite occupation, are practically agricultural labourers.

(c) Shows that terant farmers are giving up holdings and becoming bailiffs.

(d) This decline of 10 per cent. is explained by increase either of agricultural machinery or of pastoral farms.

(c) Owing to difficulty of comparing returns based upon different methods, it is impossible to give the increase of market gardeners, but it seems to be considerable. The increase of florists, \&c., is large.

(f) In 1871 a different reckoning was adopted from that of 1881 . The sum-totals afford a comparison. 


\section{APPENDIX VIII.}

TABLE 1.-Estimated Production of Gold throughout the World fiom 1852 to 1875.

(Paper handed in to the Committee on Depression of Silver, by Sir Hector Hay. No. 338 of Session 1876. Appendix, p. 25.)

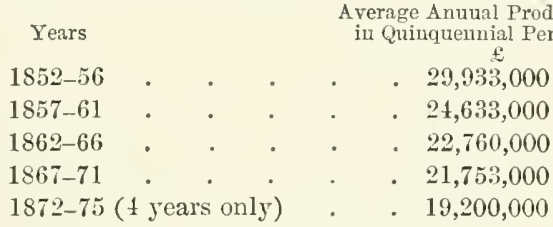

TABle 2.-Estimated Production of Gold and Silver throughout the World in Quinquennial Periods from 1851 to 1880, and in the Years 1881 to 1884. (000's omitted.) ${ }^{1}$

\begin{tabular}{|c|c|c|c|c|c|c|}
\hline \multicolumn{5}{|c|}{ Years } & \multirow{2}{*}{$\begin{array}{c}\text { Gold } \\
27,553\end{array}$} & \multirow{2}{*}{$\begin{array}{c}\text { Silver } \\
7,975\end{array}$} \\
\hline $1851-5 \overline{5}$ & . & . & . & . & & \\
\hline $1856-60$ & . & . & . & . & 28,745 & 8,144 \\
\hline $1861-65$ & . & . & . & . & 25,824 & 9,910 \\
\hline $1866-70$ & . & . & . & . & 26,770 & 12,051 \\
\hline $1871-75$ & . & . & . & - & 23,809 & 17,724 \\
\hline $1876-80$ & . & . & . & . & 24,105 & 22,052 \\
\hline 1881 . & . & . & . & . & 22,027 & 23,333 \\
\hline 1882. & . & . & . & . & 20,492 & 24,921 \\
\hline 1883 . & . & . & . & . & 20,079 & 26,059 \\
\hline 1884 . & . & . & . & . & 19,530 & 25,740 \\
\hline
\end{tabular}

1 See Report of Commission on Depression of Trade, 1886 (11), «xiii, Appendix B, Table 5. 
TABLE 3.-Imports and Exports of Gold for the Years 188i-81. (In Thousands of Pounds, 000's omitted.)

\begin{tabular}{|rr|r|c|c|c|}
\hline Year & Imports & Exports & $\begin{array}{c}\text { Excess of } \\
\text { Imports }\end{array}$ & $\begin{array}{c}\text { Excess of } \\
\text { Exports }\end{array}$ \\
\hline 1877. & $\cdot$ & 15,452 & 20,361 & - & 4,909 \\
1878. & $\cdot$ & 20,872 & 14,969 & 5,903 & - \\
1879. & $\cdot$ & 13,331 & 17,549 & - & 4,215 \\
1880. & $\cdot$ & 9,459 & 11,829 & - & 2,370 \\
1881. & $\cdot$ & 9,963 & 15,499 & - & 5,536 \\
\hline Total & 69,077 & 80,207 & 5,903 & 17,033 \\
\hline
\end{tabular}

TABLE 4.-The following are the Money Systems adopted in the Principal Nations of the World.

\begin{tabular}{|l|ll|}
\hline \multicolumn{1}{|c|}{ 1. Gold System } & $\begin{array}{l}\text { 2. Gold and Silver } \\
\text { System }\end{array}$ & 3. Silver System \\
\cline { 1 - 2 } Eugland. & France. & Holland. \\
Australia and New Zealand. & Belgium. & Austria. \\
Germany. & Italy. & Russia. \\
Norway. & Switzerland. & Egypt. \\
Sweden. & Greece. & Japan. \\
Denmark. & Spain. & China. \\
Portugal. & Roumania. & India. \\
Turkey. & United States. & Mexico. \\
Persia. & Chili. & West Indies. \\
Brazils. & Venezuela. & \\
Argentine Republic. & Paraguay. & \\
Canada. & & \\
S. Africa. & & \\
\hline
\end{tabular}




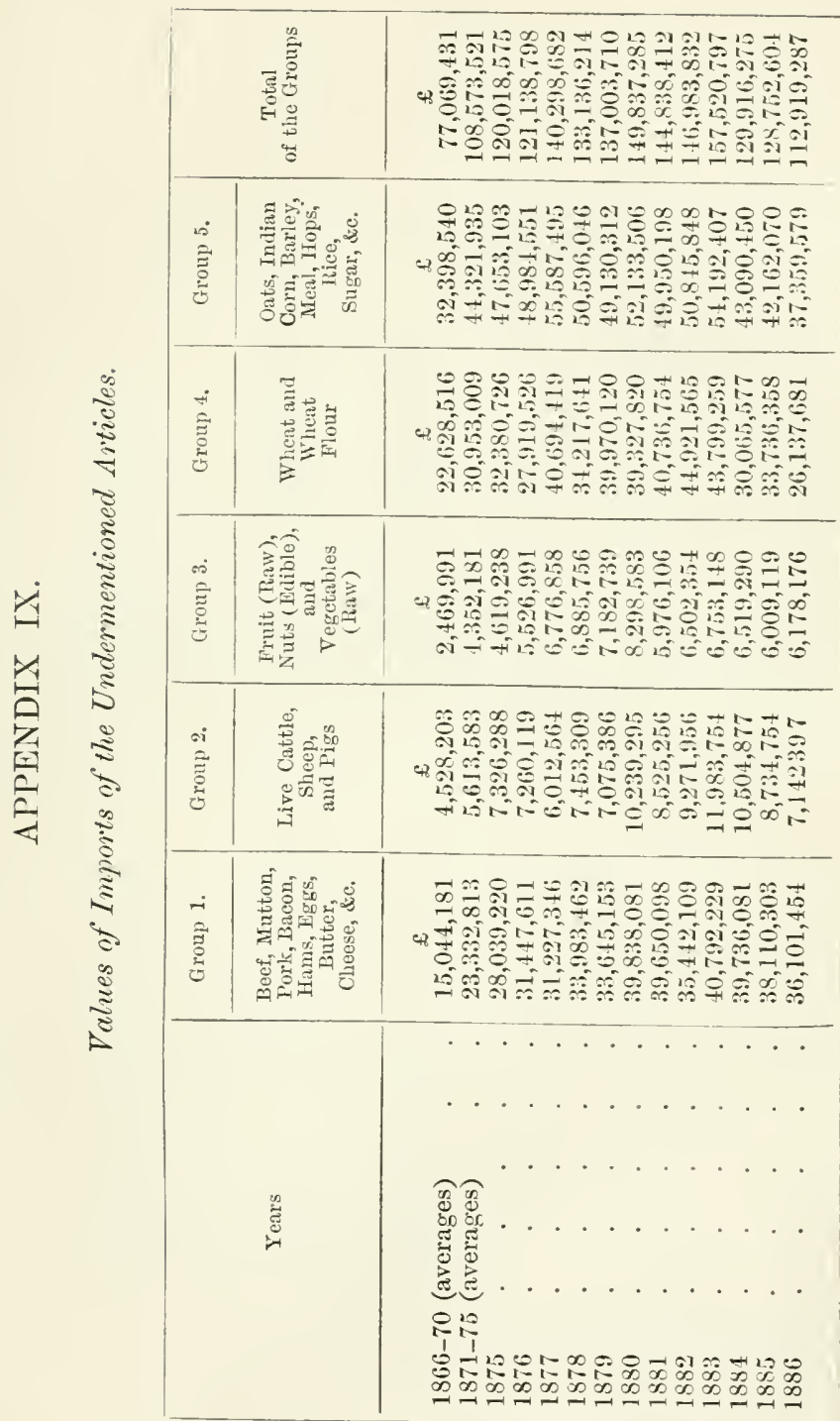


TABLE 1.-Acreage under each Description of Crop, Fallow, and

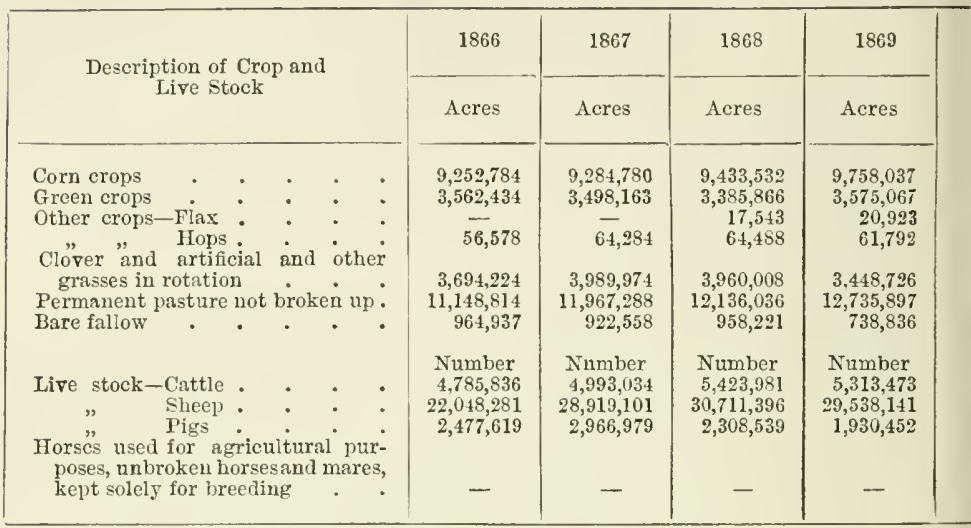

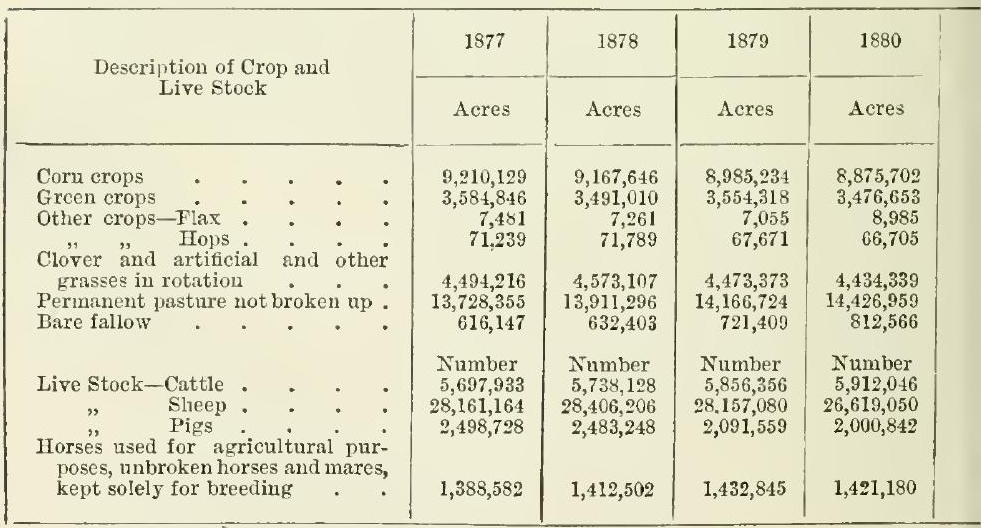




\section{-DIX X.}

Grass, and Number of Horses, Cattle, Sheep, and Pigs, in Great Britain.

\begin{tabular}{|c|c|c|c|c|c|c|}
\hline 1870 & 1871 & 1872 & 1873 & 1874 & 1875 & 1876 \\
\hline Acres & Acres & Acres & Acres & Acres & Acres & Acres \\
\hline $9,548,041$ & $9,675,261$ & $9,573,551$ & $9,458,928$ & $9,431,490$ & $9,451,650$ & $9,184,769$ \\
\hline $3,586,730$ & $3,738,180$ & $3,616,383$ & $3,576,486$ & $3,581,270$ & $3,664,107$ & $3,574,249$ \\
\hline 23,957 & 17,366 & 15,357 & 14,683 & 9,394 & 6,751 & 7,641 \\
\hline 60,594 & 60,030 & 61,927 & 63,278 & 65,805 & $69,17 \mathrm{I}$ & 69,999 \\
\hline $4,504,884$ & $4,369,448$ & $4,515,451$ & $4,366,818$ & $4,340,742$ & $4,354,071$ & $4,540,273$ \\
\hline $12,072,856$ & $12,435,442$ & $12,575,606$ & $12,915,929$ & $13,178,012$ & $13,313,621$ & $13,515,994$ \\
\hline 601,517 & 542,840 & $64 i, 898$ & 706,498 & 660,206 & 557,979 & 651,212 \\
\hline Number & Number & Number & Number & Number & Number & Number \\
\hline $5,403,317$ & $5,337,579$ & $5,624,994$ & $5,964,549$ & $6,125,491$ & $6,012,824$ & $5,846,302$ \\
\hline $28,397,589$ & $27,119,569$ & $37,921,507$ & $29,427,635$ & $30,313,941$ & $29,167,438$ & $28,172,951$ \\
\hline $2,171,138$ & $2,499,602$ & $2,771,749$ & $2,500,259$ & $2,422,832$ & $2,229,018$ & $2,293,620$ \\
\hline $1,266,709$ & $1,254,450$ & $1,258,020$ & $1,276,441$ & $1,313,739$ & $1,340,129$ & $1,374,576$ \\
\hline
\end{tabular}

\begin{tabular}{|c|c|c|c|c|c|c|}
\hline 1881 & 1882 & 1883 & 1884 & 1885 & 1886 & 1887 \\
\hline Acres & Acres & Acres & Acres & Acres & Acres & Acres \\
\hline $8,847,976$ & $8,833,380$ & $8,618,675$ & $8,484,730$ & $8,392,006$ & $8,260,165$ & $8,145,894$ \\
\hline $3,510,568$ & 3475,660 & $3,454,579$ & $3,487,703$ & $3,521,612$ & $3,480,480$ & $3,463,706$ \\
\hline 6,534 & 5,220 & 4,317 & 2,247 & $\mathbf{2 , 4 9 0}$ & 3,068 & 3,072 \\
\hline 64,943 & 65,619 & 68,016 & 69,258 & 71,327 & 70,127 & 63,706 \\
\hline 4,342,285 & 4,327,392 & $4,395,922$ & 4,381,404 & $4,654,173$ & $4,689,200$ & $4,781,027$ \\
\hline $14,643,397$ & $14,821,675$ & $15,065,373$ & $15,290,820$ & $15,342,478$ & $15,535,279$ & $15,671,395$ \\
\hline 795,809 & 784,425 & 778,203 & 749,699 & 560,322 & ว52,898 & 485,874 \\
\hline Number & Number & Number & Number & Number & Number & Number \\
\hline $\mathbf{5}, 911,642$ & $5,807,491$ & $5,962,779$ & $6,269,141$ & $6,597,964$ & $6,646,683$ & $6,491,268$ \\
\hline $24,581,053$ & $24,319,768$ & $25,068,271$ & $26,068,354$ & $26,534,635$ & $25,520,718$ & $25,958,768$ \\
\hline $2,048,090$ & $2,510,402$ & $2,617,757$ & $2,584,391$ & $2,403,380$ & $2,221,475$ & $2,299,323$ \\
\hline $1,424,938$ & $1,413,578$ & $1,410,596$ & $1,414,377$ & $1,408,789$ & $1,425,359$ & $1,428,383$ \\
\hline
\end{tabular}




\section{STATISTICS OF AGRICULTURE.}

TABLE II.-Acreage under each kind of Crop, Bure Fallow, and Grass, and IIorses, Cattle, Sheep, and Pigs, in the Fear 1887, in each Division of Great Britain; with the Totals for Great Britain.

\begin{tabular}{|c|c|c|c|c|}
\hline & $\begin{array}{l}\text { ENGLAND, } \\
1887\end{array}$ & $\begin{array}{l}\text { WALES, } \\
18 S 7\end{array}$ & $\begin{array}{l}\text { ScotuAND } \\
1887\end{array}$ & $\begin{array}{l}\text { GREAT } \\
\text { BRITAIS, } \\
\quad \mathbf{1 8 8 7}\end{array}$ \\
\hline & Acres & Acres & Aeres & Acres \\
\hline Total area of land and water. & $32,597,398$ & $4,721,823$ & $19,466,978$ & $56,786,199$ \\
\hline $\left.\begin{array}{l}\text { Total acreage nuder all kinds } \\
\text { of crops, bare fallow, auil } \\
\text { grass }{ }^{2} \cdot{ }^{*} \cdot{ }^{*}\end{array}\right\}$ & $21,922,052$ & $2,831,155$ & $4,862,097$ & $32,615,304$ \\
\hline 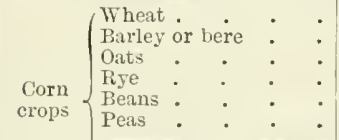 & $\begin{array}{r}2,197,580 \\
1,759,636 \\
1,768,123 \\
45,994 \\
343,673 \\
226,002\end{array}$ & $\begin{array}{r}69,407 \\
118,920 \\
255,434 \\
1,349 \\
2,078 \\
2,142\end{array}$ & $\begin{array}{r}50,337 \\
206,600 \\
1,064,432 \\
7,817 \\
18,963 \\
1,407\end{array}$ & $\begin{array}{r}2,317,324 \\
2,085,156 \\
3,087,989 \\
55,160 \\
370,714 \\
229,551\end{array}$ \\
\hline Total . . . & $6,347,008$ & $4 \cdot 49,330$ & $1,349,556$ & $8,145,894$ \\
\hline 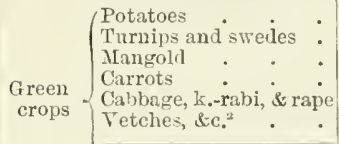 & $\begin{array}{r}369,243 \\
1,119,268 \\
351,588 \\
14,468 \\
145,690 \\
380,286\end{array}$ & $\begin{array}{r}40,570 \\
70,487 \\
7,764 \\
459 \\
1,343 \\
4,592\end{array}$ & $\begin{array}{r}119,839 \\
482,532 \\
1,338 \\
1,115 \\
6,640 \\
16,484\end{array}$ & $\begin{array}{r}559,652 \\
1,972,287 \\
360,690 \\
16,042 \\
153,673 \\
401,362\end{array}$ \\
\hline Total & $2,680,543$ & 125,215 & 657,948 & $3,463,706$ \\
\hline $\begin{array}{l}\text { Clover, sainfoin, } \\
\text { \& grasses wuler }\end{array}$ & $\begin{array}{l}1,708,719 \\
1,116,415\end{array}$ & $\begin{array}{l}175,119 \\
137,255\end{array}$ & $\begin{array}{r}411,120 \\
1,202,399\end{array}$ & $\begin{array}{l}2,324,958 \\
2,456,069\end{array}$ \\
\hline Total & $2,825,134$ & 312,371 & $1,643,519$ & $4,781,027$ \\
\hline 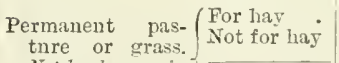 & $\begin{array}{l}3,926,513 \\
8,619,990\end{array}$ & $\begin{array}{r}483,771 \\
1,415,375\end{array}$ & $\begin{array}{r}152,076 \\
1,043,670\end{array}$ & $\begin{array}{r}4,562,360 \\
11,109,035\end{array}$ \\
\hline $\begin{array}{lll}\text { Not broken } & \text { up } \\
\text { rotution }^{3} & .\end{array}$ & $12,546,503$ & $1,929,146$ & $1,195,746$ & $15,671,395$ \\
\hline $\begin{array}{l}\text { Flax } \\
\text { Hops } \\
\text { Bare faliow or nncropped arable } \\
\text { land }\end{array}$ & $\begin{array}{r}2,746 \\
63,706\end{array}$ & $\begin{array}{l}{ }^{56} \\
15,034\end{array}$ & $\begin{array}{l}900 \\
\cdots \\
14,428\end{array}$ & $\begin{array}{r}3,702 \\
63,706\end{array}$ \\
\hline
\end{tabular}

1 Not inclnding nursery-gronnds and woods, and that part of the acreage of orchards and market gardens which is not devoted to any of the crops or grass mentioned in the above table.

2 Except clover and grass, which are separately shown.

3 Exclusive of heath and monntain land. 
Appendix $X$.-Table II. continued.

\begin{tabular}{|c|c|c|c|c|c|}
\hline & & $\begin{array}{l}\text { EXGLAXD, } \\
1887\end{array}$ & $\begin{array}{l}\text { WALES, } \\
1887\end{array}$ & $\begin{array}{l}\text { SCOTLAND } \\
1887\end{array}$ & $\begin{array}{l}\text { GRFAT } \\
\text { BRITAN, } \\
\text { 1887 }\end{array}$ \\
\hline & & Number & Number & Number & Number \\
\hline \multirow{3}{*}{ Horses $^{1}$} & $\left(\begin{array}{c}\text { Used solely for agri- } \\
\text { culture }\end{array}\right.$ & 766,693 & 72,354 & 142,083 & 981,130 \\
\hline & $\left.\begin{array}{l}\text { Unbroken horses, and } \\
\text { mares kept solely } \\
\text { for breeding }\end{array}\right\}$ & 330,509 & 67,771 & 48,970 & 447,253 \\
\hline & . $\quad$. & $1,097,202$ & 140,128 & 191,053 & $1,428,383$ \\
\hline \multirow{3}{*}{ Cattle } & $\left\{\begin{array}{c}\text { Cows and heifers in } \\
\text { milk or in calf }\end{array}\right\}$ & $1,841,664$ & 282,686 & 411,930 & $2,536,280$ \\
\hline & $\begin{array}{l}\text { Other }\left\{\begin{array}{l}2 \text { years \& above } \\
\text { cattle }\end{array} \text { Under } 2 \text { years }\right.\end{array}$ & $\begin{array}{l}1,160,887 \\
1,621,164\end{array}$ & $\begin{array}{l}131,934 \\
282,617\end{array}$ & $\begin{array}{l}266,252 \\
412,131\end{array}$ & $\begin{array}{l}1,559,073 \\
2,345,915\end{array}$ \\
\hline & Total & $4,623,715$ & 697,237 & $1,120,316$ & $6,441,268$ \\
\hline \multirow{2}{*}{ Sheep } & $\left\{\begin{array}{l}1 \text { year old and above } \\
\text { Under } 1 \text { year old }\end{array}\right.$ & $\begin{array}{l}9,930,719 \\
6,521,789\end{array}$ & $\begin{array}{r}1,804,465 \\
935,894\end{array}$ & $\begin{array}{l}4,411,065 \\
2,354.836\end{array}$ & $\begin{array}{r}16,146,249 \\
9,812,519\end{array}$ \\
\hline & Total & $16,452,508$ & $2,740,359$ & $6,765,901$ & $25,958,768$ \\
\hline Pigs 2 & 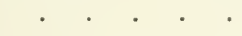 & $1,940,507$ & 223,170 & 135,646 & $2,299,323$ \\
\hline
\end{tabular}

${ }^{1}$ As returned by occupiers of land.--Including ponies.

2 The number of pigs is exclusive of those kept in towns, and by cottagers with less than a quarter of an acre of laud. 


\section{APPENDIX XI.}

TABLE 1 (a).-The Land of England and Wales and its Products in 1688. (Davenant on Trade, vol. ii. p. 219.)

\begin{tabular}{|c|c|c|c|}
\hline & Acres & Talue per acre & Rent \\
\hline $\begin{array}{l}\text { Arable land } \\
\text { Pasture and meadow. } \\
\text { Woods and coppices . } \\
\text { Forests, parks, and com- } \\
\text { mons } \\
\text { Heaths, moors, mountains, } \\
\text { and barren land } \\
\text { Houses and homestears, } \\
\text { gardens and orchards, } \\
\text { churchesand churchyards } \\
\text { Rivers, lakes, meres, and } \\
\text { ponds. . . } \\
\text { Roads, ways, and waste } \\
\text { land . . . }\end{array}$ & $\begin{array}{r}9,000,000 \\
12,000,000 \\
3,000,000 \\
3,000,000 \\
10,000,000 \\
1,000,000\{ \\
500,000 \\
500,000\end{array}$ & 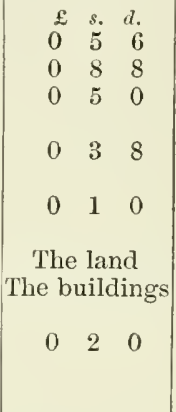 & $\begin{array}{r}\stackrel{£}{2} \\
2,480,000 \\
5,200,000 \\
750,000 \\
570,000 \\
500,000 \\
450,000 \\
2,000,000 \\
50,000\end{array}$ \\
\hline In all & $39,000,000$ & about 6 & $12,000,000$ \\
\hline
\end{tabular}

TABLE $1(b) .-A n$ Estimate of the Live Stock of England and Wales in 1688.

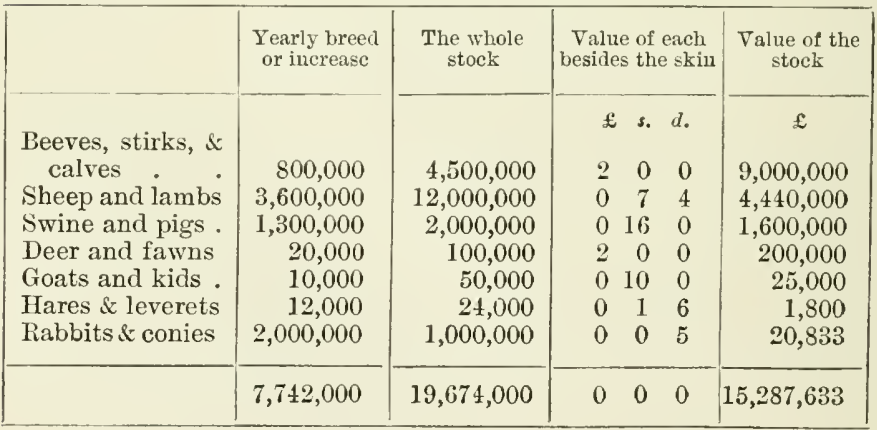


TABLE 2-Arthur Young's Estimate (1771) of the (A) Area of Cultivation, $(B)$ Capital employed by the Farmer, (C) Product of the Soil, and (D) Live Stock in England and Wales.

(a) arable State of the Soll of England and Wales.

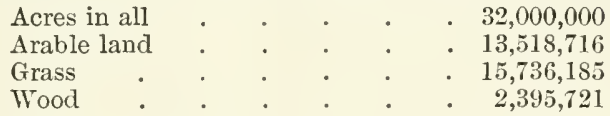

(B) Capital employed by the Farmer.

(i.) Stock in Husbandry.

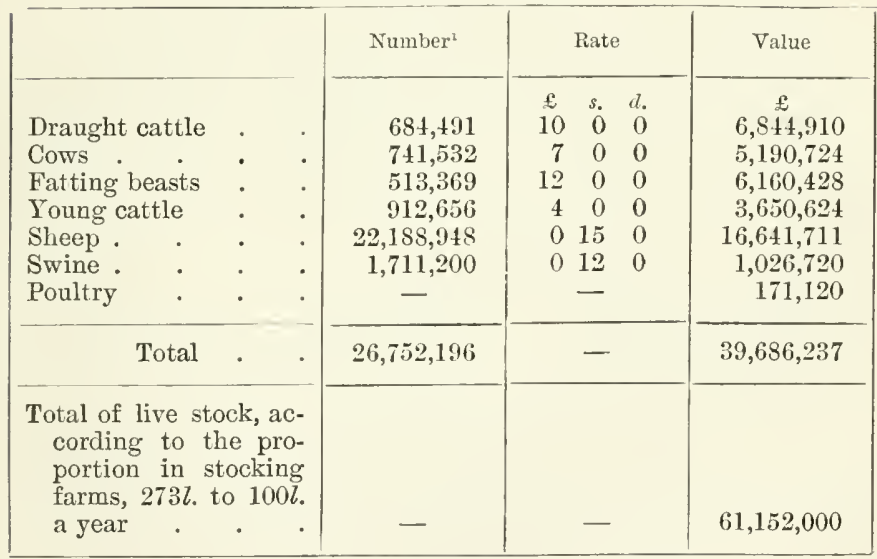

(ii.) Dead Stock.

Implements at $70 l$. per 100l. a year _ . . 15,680,000 Furniture

$" \quad$ "Total $\quad \cdot \quad \cdot \quad \cdot \frac{15,680,000}{31,360,000}$

T The number of the stock (swine excepted) is the actual number; the value is Young's conjecture. 
(B) Capital employed by the Farier-continued.

(iii.) Sundries. Including seed, labour, \&c. ․ $\quad$. $51,520,000$

(iv.) Recapitulation.

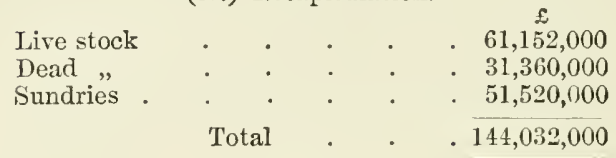

(C) Product of the Soll.

Arable Crops.

\begin{tabular}{|c|c|c|c|c|c|}
\hline Crops & Acres & $\begin{array}{l}\text { Product } \\
\text { per acre }\end{array}$ & Total product & $\begin{array}{c}\text { Pe } \\
\text { quarter }\end{array}$ & Talue \\
\hline Wheat & $2,795,008$ & $\begin{array}{l}\text { Quarters. } \\
30\end{array}$ & $\begin{array}{l}\text { Quartcrs. } \\
8,385,024\end{array}$ & $\begin{array}{l}s . \\
40\end{array}$ & 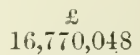 \\
\hline Barley & $2,623,885$ & 40 & $10,495,540$ & 20 & $10,495,540$ \\
\hline Oats & $1,483,065$ & 46 & $7,044,558$ & 16 & $5,635,645$ \\
\hline Peas & 513,369 & 27 & $1,+75,935$ & 26 & $1,918,714$ \\
\hline Leans & 399,287 & $\begin{array}{l}4 \quad 1 \\
\& \quad s . \quad \text { a. }\end{array}$ & $1,647,058$ & 26 & $2,141,174$ \\
\hline $\begin{array}{l}\text { Turnips } \\
\text { Clover }\end{array}$ & $\begin{array}{l}1,711,228 \\
3,201,425\end{array}$ & $\begin{array}{lll}2 & 2 & 5 \\
5 & 4 & 0\end{array}$ & & & $\begin{array}{r}3,629,228 \\
16,647,410\end{array}$ \\
\hline Total & $12,707,268$ & - & $29,048,115$ & - & $57,237,759$ \\
\hline
\end{tabular}

(D) Cattle.

\begin{tabular}{|c|c|c|c|c|}
\hline & & Rate per head & Number & Total \\
\hline $\begin{array}{l}\text { Cows . } \\
\text { Sheep : } \\
\text { Fatting beasts } \\
\text { Young cattle } \\
\text { Swine . } \\
\text { Poultry }\end{array}$ & $\begin{array}{l}\cdot \\
\cdot \\
\cdot \\
\cdot\end{array}$ & $\begin{array}{rrr}\stackrel{L}{\varepsilon} & s . & d . \\
5 & 10 & 0 \\
0 & 11 & 8 \\
5 & 0 & 0 \\
1 & 0 & 0 \\
0 & 15 & 0\end{array}$ & $\begin{array}{r}741,532 \\
22,188,948 \\
513,369 \\
912,656 \\
1,711,200\end{array}$ & $\begin{array}{r}£ \\
4,078,426 \\
12,943,551 \\
2,566,845 \\
912,656 \\
1,283,400 \\
171,120\end{array}$ \\
\hline Total & . & - & $26,067,705$ & $21,955,998$ \\
\hline
\end{tabular}


Table 3.-The Proportion of Land cultivated for Different Purposes in England and Wales in 1808.

(An Inquiry into the State of National Subistence. By W. T. Comber. London, 1808. Appendix XXV.)

Crops.

Wheat

Barley and rye.

Oats and beans

Clover, rye, sc. .

Roots and cabbages cultivated by the plough .

Fallow

Hop-grounds

Nursery-grounds

Fruit and kitchen gardens cultivated by the spade

Pleasure-grounds

Lands depastured by cattle

Herlgerows, copses, and woods

Ways, water, sc.

Total cultivated area

Commons and waste lands

Total acreage of England and Wales
Acres.

$$
\text { - } 3,160,000
$$

861,000

- $2,872.000$

- $1,149,000$

$1,150,000$

$2,297,000$

36,000

9,000

$+1,000$

16,000

- $17,479,000$

- $1,641,000$

- $1,316,000$

. $32,027,000$

- $6,473,000$

. $38,500,000$

Table 4.-Mr. W. Couting's General Statement of the Superficial Area of Englund and Wrales in 1827.

(Select Committee on Emigration, 1827. Sissional Pupers, 1827, vol.v.)

\begin{tabular}{|c|c|c|c|c|c|}
\hline $\begin{array}{l}\text { Territorial } \\
\text { divisions }\end{array}$ & $\begin{array}{l}\text { Arable land } \\
\text { and gardens }\end{array}$ & $\begin{array}{c}\text { Meertows, pas- } \\
\text { tures, and } \\
\text { marshes }\end{array}$ & $\begin{array}{l}\text { Uncultivater } \\
\text { improveable } \\
\text { wastes }\end{array}$ & $\begin{array}{l}\text { Unimprove- } \\
\text { able wastes }\end{array}$ & $\begin{array}{l}\text { Total } \\
\text { aereage }\end{array}$ \\
\hline & Acres & Acres & Aeres & Aeres & Acres \\
\hline England & $10,252,800$ & $15,879,200$ & $3,454,000$ & $3,256,400$ & $32,342,400$ \\
\hline Wales. & 890,570 & $\because, 226,430$ & 530,000 & $1,105,000$ & $4,752,000$ \\
\hline Total & $11,143,370$ & $17,605,630$ & $3,984,000$ & $4,361,400$ & $37,094,400$ \\
\hline
\end{tabular}


TABle 5.-Total Acreage under each kind of Crop, Bare Fallow, and Grass ; Total Acreage of Orchards, Market Gardens, Nursery-grounds, and Woods; and Number of each kind of Live stock in Great Britain in each of the Years 1867, $1877,1887$.

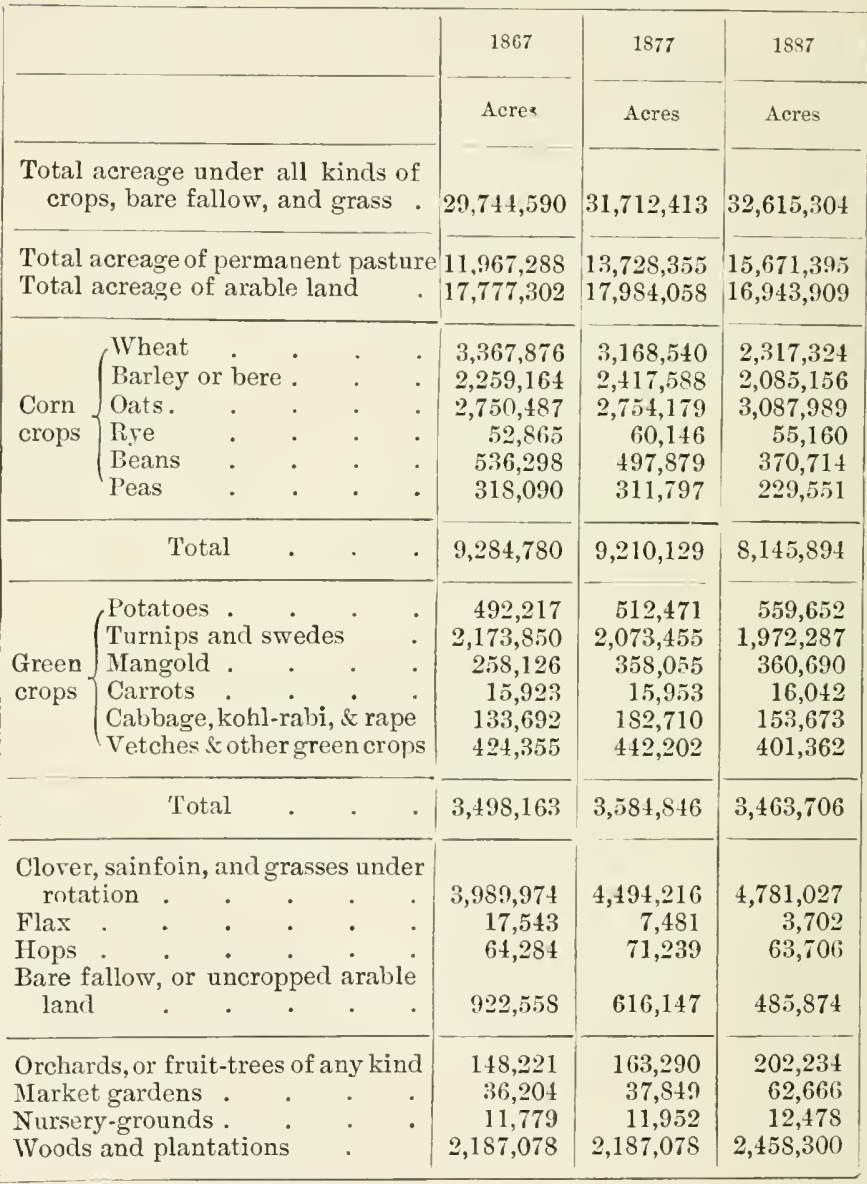


Appendix XI.-continued.

\begin{tabular}{|c|c|c|c|c|}
\hline & & 1867 & 1877 & 1887 \\
\hline & & Number & Number & Number \\
\hline \multicolumn{2}{|c|}{ Horses $\left\{\begin{array}{c}\text { Used solely for agriculture } \\
\text { Unbroken horses \& mares } \\
\text { kept solely for breeding }\end{array}\right.$} & $\begin{array}{l}965,515 \\
301,194\end{array}$ & $\begin{array}{l}970,786 \\
417,796\end{array}$ & $\begin{array}{l}981,130 \\
447,253\end{array}$ \\
\hline & Total & $1,266,709$ & $1,388,582$ & $1,428,383$ \\
\hline \multicolumn{2}{|c|}{ Cattle $\left\{\begin{array}{l}\text { Cows and heifers in milk } \\
\text { or in calf } \dot{2} \text { years old } \\
\text { other cattle }: 2 \text { above } \dot{ } . \\
\text { Ditto under } 2 \text { years old } .\end{array}\right.$} & $\begin{array}{l}2,038,092 \\
1,266,753 \\
1,688,189\end{array}$ & $\begin{array}{l}2,207,017 \\
1,464,317 \\
2,026,599\end{array}$ & $\begin{array}{l}2,536,280 \\
1,559,073 \\
2,345,915\end{array}$ \\
\hline & . $\quad$. & $4,993,034$ & $5,697,933$ & $6,441,268$ \\
\hline \multicolumn{2}{|c|}{ Sheep $\left\{\begin{array}{l}1 \text { year old and above } \\
\text { Under } 1 \text { year old }\end{array}\right.$} & $\begin{array}{l}18,449,005 \\
10,470,096\end{array}$ & $\begin{array}{l}18,145,205 \\
10,015,959\end{array}$ & $\begin{array}{r}16,146,249 \\
9,812,519\end{array}$ \\
\hline & Total & $28,919,101$ & $28,161,164$ & $25,958,768$ \\
\hline Pigs & ..$\quad$. & $2,966,979$ & $2,498,728$ & $2,299,323$ \\
\hline
\end{tabular}




\section{APPENDIX XII.}

Return showing Price of Wheat per English Quarter in France, Belgium, and Prussia in the Years 1835, 1845, 1855, and 1885, and the Import Duties on Wheat per English Quarter in the same Countries at the same periods (so far as can be given).

\begin{tabular}{|c|c|c|c|c|c|c|c|c|}
\hline \multicolumn{5}{|c|}{ Price per English Quarter } & \multicolumn{4}{|c|}{ Import Duty per English Quarter } \\
\hline Countries & 1835 & 1845 & 1855 & 1885 & 1835 & 1845 & 1855 & 1885 \\
\hline & s. d. & s. d. & s. d. & s. d. & s. $d$. & s. $d$. & s. $d$. & s. $d$. \\
\hline France & $35 \quad 2$ & $45 \quad 9$ & $47 \quad 2$ & $39 \quad 1$ & sliding scale & do. & do. & $\left\{\begin{array}{c}1885 \\
5 \text { 3after7Мау }\end{array}\right.$ \\
\hline Belgium & & $46 \quad 8$ & & & 80 & 04 & free & $\begin{array}{c}1855 \\
\text { free } \\
22 \text { to } 20 \mathrm{Feb} .\end{array}$ \\
\hline Prussia & $23 \quad 2$ & $35 \quad 4$ & 600 & 350 & no info & mation & 28 & $\begin{cases} & 1885 \\
6 \quad 6 \quad \text { after } & 20\end{cases}$ \\
\hline England & 394 & 5010 & 748 & $41 \quad 2$ & sliding scale & do. & free & $\begin{array}{l}\text { Feb. } 1885 \\
\text { free }\end{array}$ \\
\hline
\end{tabular}




\section{APPENDIX XIII.}

TABLE 1.-Rates in $1803,1815,1827$, and 1841 .
(1) In 1803 the total burden of the rates was
$\stackrel{\stackrel{£}{\Sigma}}{5,8 \pm 8,000}$
(2) In 1815
(3) In 1827
(4) In 1841
",
"
$8,164,000$
$\begin{array}{lr}, & 9,189,687 \\ , & 9,487,027\end{array}$
"

(1) and (2) No figures for the earlier years will supply the items in detail. But for the two latter years the information is more detailed.

(3) $1827-$

1. Poor and county rates . . . . $7,803,465$

2. Highway rates . . . . . . $1,121,834$

3. Church rates . . . . . . 564,388

$$
\text { Total . . . . } £ \overline{\$ 9,489,687}
$$

(4) 1841 - (A) Direct Taxation (Rates).

1. Poor rate $\quad . \quad$. $\quad 5,69 \stackrel{\mathcal{E}}{5}, 151$

2. County and police rate . . $\quad 963,223$

3. Highway rate * . . 1,169,891

4. Church rate . . . . 506,812

5. Borough rate . . . . 246,743

6. Sewer rate (MLetropolitan) . $\quad 75,000$ 
(B) Indirect Taxation (Tolls, Fares, and Dues). Brought forward . . $£ 8,651,820$

1. Borough tolls . . . . 172,911

2. City of London . . . 188,521

3. Turnpike tolls . . . $1,348,081$

4. Light dues . . . . 243,023

5. Port dues . . . . 525,000

6. Fees in administration of justice . . . . . $\quad 57,668$

Total . . . . $£ 11,187,027$

TABLE 2.-Local Taxation in 1873 and 1885 (omitting purely Uiban and Metropolitan).

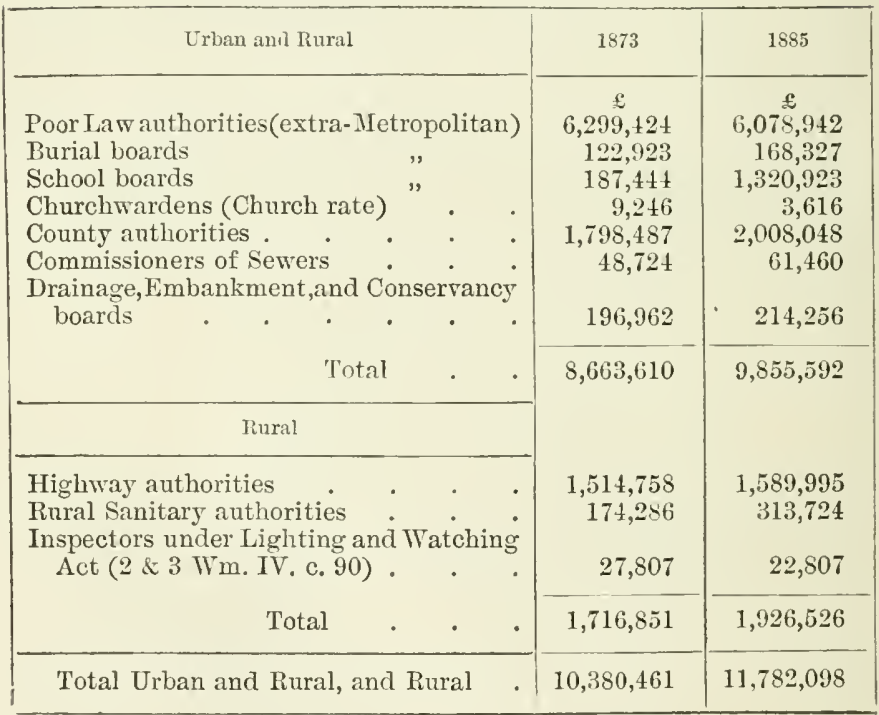




\section{APPENDIX XIV.}

\section{ALLOTMENTS IN ENGLAND AND WALES.}

Tre number of agricultural labourers, farm servants, and cottagers (not including females and shepherds) in England and Wales is 807,608 persons.

The following table shows-(1) How many labourers have (a) potato-grounds; (b) cow-runs, whether general or definite (and in the latter case the acreage). (2) The number and size of allotments, whether field gardens or attached to cottages, from under $\frac{1}{8}$ of an acre to 4 acres.

In this table no allotments given by railway companies to their servants are included. Throughout the table the English counties, in which the allotments, \&c., are situated, have been classified in four divisions :

I. Easters and North-Eastern, including Bedford, Cambridge, Essex, Herts, Hunts, Lincoln, Norfolk, Suffolk, East Ricling of Yorkshire.

II. South-eastern and East Midland, including Berks, Bucks, Hants, Kent, Leicester, Middlesex, Northants, Notts, Oxford, Rutland, Surrey, Sussex, Warwick.

III. West Midland and South-Western, including Cornwall, Devon, Dorset, Gloucester, Hereford, Monmouth, Shropshire, Somerset, Wilts, Worcester.

IV. North AND North-western, including Chester, Cumberland, Derby, Durham, Lancaster, Northumberland, Stafford, Westmoreland, North and West Ridings of Yorkshire.

The first two constitute the corn division; the last two the grazing division of the country. 
APPENDIX XIV.

\begin{tabular}{|c|c|c|c|c|c|}
\hline \multicolumn{2}{|c|}{ 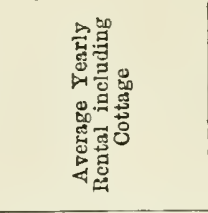 } & 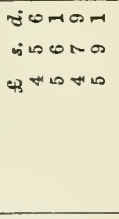 & $\frac{\sim}{\Rightarrow}$ & 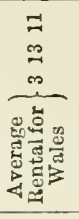 & 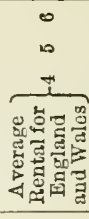 \\
\hline \multicolumn{2}{|c|}{ 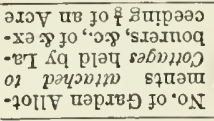 } & 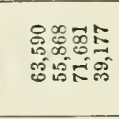 & 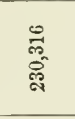 & 总 & 总 \\
\hline \multirow{7}{*}{ 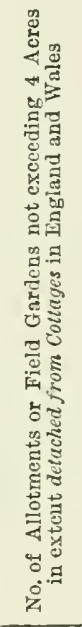 } & \multirow{3}{*}{ 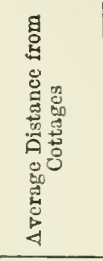 } & 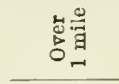 & 点 & ஜ & $\begin{array}{l}\vec{\circ} \\
\text { ली }\end{array}$ \\
\hline & & 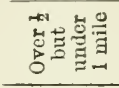 & $\begin{array}{l}5 \\
\text { G } \\
0 \\
0 \\
\text { in }\end{array}$ & छै & $\begin{array}{l}\infty \\
: \\
0 \\
0 \\
0 \\
0\end{array}$ \\
\hline & & 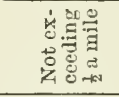 & $\begin{array}{l}\overrightarrow{0} \\
\vec{m} \\
=\end{array}$ & $\stackrel{5}{5}$ & $\begin{array}{l}\stackrel{2}{2} \\
\stackrel{+}{\infty} \\
\infty \\
0 \\
0\end{array}$ \\
\hline & 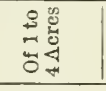 & 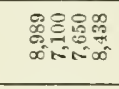 & $\underset{\mathrm{s}}{\mathrm{E}}$ & $\stackrel{8}{i}$ & חొ \\
\hline & 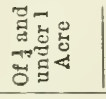 & 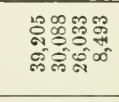 & 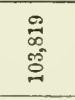 & ஜ̊: & 昜 \\
\hline & 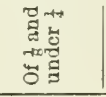 & 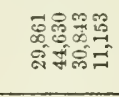 & 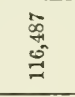 & 尽 & 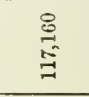 \\
\hline & 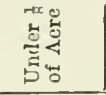 & 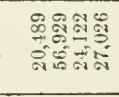 & 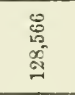 & 윤 & 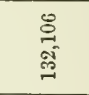 \\
\hline \multicolumn{2}{|c|}{ 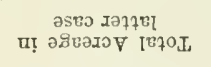 } & 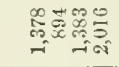 & $\underset{\substack{5 \\
\text { in } \\
\text { in }}}{ }$ & 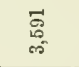 & 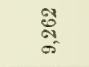 \\
\hline \multirow{2}{*}{ 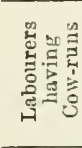 } & 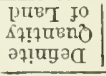 & 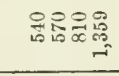 & $\begin{array}{l}\text { E } \\
\text { of } \\
\text { s }\end{array}$ & $\stackrel{\vec{a}}{-}$ & $\stackrel{\substack{9 \\
=}}{\rightarrow+}$ \\
\hline & 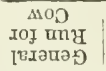 & 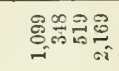 & 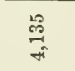 & $\begin{array}{l}\infty \\
\ddot{\infty}\end{array}$ & 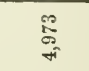 \\
\hline \multicolumn{2}{|c|}{ 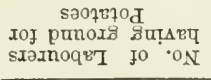 } & 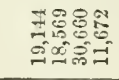 & $\begin{array}{l}\stackrel{2}{0} \\
\stackrel{5}{\infty}\end{array}$ & 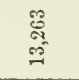 & 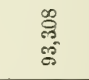 \\
\hline \multicolumn{2}{|c|}{ 总 } & 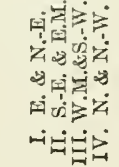 & 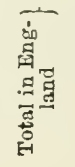 & 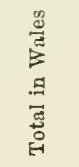 & 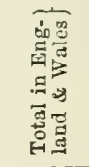 \\
\hline
\end{tabular}




\section{APPENDIX XV.}

Table of Agricultural Wages in England, 1824, 1836, 1860, 1870, 1881.' It must, however, be noticed that this Table does not include Payments for Piece or Task Work, or Allowances.

\begin{tabular}{|c|c|c|c|c|c|c|c|c|c|c|c|c|c|c|}
\hline \multirow{2}{*}{\multicolumn{5}{|c|}{ Divisions and Counties }} & \multicolumn{10}{|c|}{ A verage Weekly Wages of Men } \\
\hline & & & & & \multicolumn{2}{|c|}{1824} & \multicolumn{2}{|c|}{1836} & \multicolumn{2}{|c|}{1860} & \multicolumn{2}{|c|}{1870} & \multicolumn{2}{|c|}{1881} \\
\hline \multicolumn{5}{|c|}{$\begin{array}{c}\text { I. Eastern and North- } \\
\text { eastern. }\end{array}$} & & & & & & & s. & & & \\
\hline Bedford & & . & . & - & & 7 & 9 & 6 & 10 & 3 & 12 & 0 & $\ddot{13}$ & 0 \\
\hline Cambridge & & . & . & . & & & 9 & 6 & 10 & 0 & 11 & 0 & 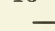 & \\
\hline Essex & . & - & . & . & 9 & 4 & 10 & 4 & 11 & 3 & 11 & 0 & 13 & 6 \\
\hline Eertford & & . & . & . & 9 & 0 & 9 & 6 & 10 & 0 & 12 & 0 & 13 & 0 \\
\hline Huntingdo & & . & . & . & & & 9 & 6 & 10 & 9 & 10 & 6 & 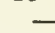 & \\
\hline Lincoln & . & . & . & . & 10 & 2 & 12 & 0 & 13 & 0 & 14 & 0 & 13 & 6 \\
\hline Norfolk & . & . & . & . & 9 & 1 & 10 & 4 & 10 & 7 & 11 & 6 & 13 & 6 \\
\hline Suffolk & . & . & . & . & 8 & 3 & 10 & 4 & 10 & 7 & 11 & 0 & 13 & 6 \\
\hline East Ridir & & . & . & . & 11 & 8 & 12 & 0 & 13 & 6 & 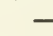 & & 17 & 6 \\
\hline \multicolumn{2}{|c|}{ Average } & . & . & . & 9 & & 10 & 3 & 11 & 1 & 11 & 7 & 13 & 10 \\
\hline \multicolumn{5}{|c|}{$\begin{array}{l}\text { II. South-eastern and } \\
\text { East Midland. }\end{array}$} & & & \multirow{2}{*}{\multicolumn{2}{|c|}{-}} & \multirow{2}{*}{\multicolumn{2}{|c|}{100}} & \multirow{2}{*}{\multicolumn{2}{|c|}{96}} & & \\
\hline Berks & . & - & . & . & & - & & & & & & & 12 & 0 \\
\hline Bucks & . & . & . & . & & & 8 & 0 & 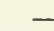 & & - & & 14 & 0 \\
\hline Hants & . & . & . & . & 8 & 6 & 9 & 6 & 12 & 0 & 10 & 9 & 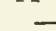 & \\
\hline Kent . & . & . & . & . & 11 & 9 & 12 & 0 & 12 & 0 & 14 & 0 & 14 & 0 \\
\hline Leicester & . & . & . & . & & - & 10 & 0 & 13 & 0 & 13 & 0 & 13 & 0 \\
\hline Middlesex & & . & . & . & & & 10 & 6 & 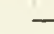 & & - & & - & \\
\hline Northants & . & . & . & . & 8 & 1 & 9 & 0 & 11 & 0 & 11 & 6 & 13 & 0 \\
\hline Notts. & . & . & . & . & 10 & 3 & 12 & 0 & 12 & 9 & 13 & 3 & 13 & 6 \\
\hline Oxford & . & . & . & . & & - & 9 & 0 & - & & 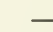 & & 13 & 3 \\
\hline Rutland & . & . & . & . & & - & 9 & 0 & - & & 12 & 6 & $\rightarrow$ & \\
\hline Surrey & . & . & . & . & 10 & 8 & 10 & 6 & 12 & 9 & 13 & 0 & 16 & 0 \\
\hline Sussex & . & . & . & . & & 7 & 10 & 7 & 11 & 8 & 12 & 0 & 16 & 0 \\
\hline Warwick & . & . & . & . & & & 10 & 0 & 10 & 9 & 12 & 6 & 16 & 0 \\
\hline Aver & rage & . & . & . & 9 & 8 & 10 & 0 & 11 & 9 & 12 & 2 & 14 & 0 \\
\hline
\end{tabular}

1 The materials from which these Tables of Wages and also that of Prices (Table 3) are principally compiled are Mr. Purdy's paper on 


\section{Appendix $X V$. -continued.}

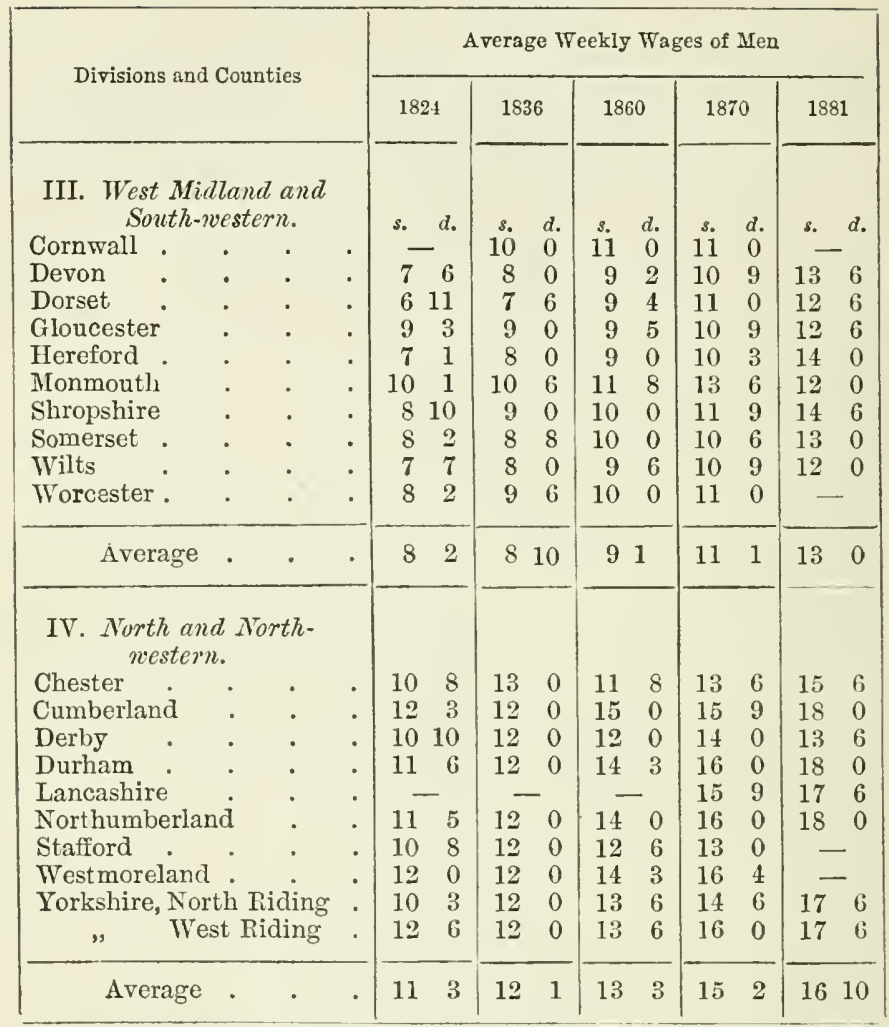

Agricultural Wages (Statistical Society, vol. xxiv.); the Evidence before the Agricultural Commissions of 1833,1836 , and 1879-81; the Return of Agricultural Earnings (Parliamentary Paper's, No. 14, Sess. 1861); the Labour Statistics Return of Wages (Parliamentary Papers, 1887, c. 5,172) ; Mr. Giffen's Presidential Address on the Progress of the Working Classes in the last Half-century (Statistical Society, vol. xlvi.); Evidence before the Lords Committee on the Poor, 1830-31; and the Reports of the Poor Law Commissioners, passim. 


\section{APPENDIX XVI.}

TABLe 1.-Arthur Young's Calculations of Wages and Prices."

1. The average wages of agricultural labourers, taking into account extra pay at harvest and haymaking, and commuting food allowances in money, is-in the South and East, 7s. 10d.; in the North, $7 s .1 d$. He adds that in the former case wages had risen by a quarter in the last eighteen years.

2. Prices of provisions, \&c. :-

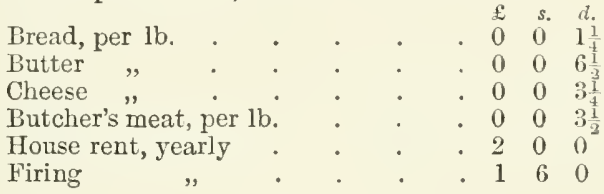

TABLE 2.-Prices ${ }^{2}$ of Articles of Food, \&c., in 1815, 1836, 1860, 1887.

\begin{tabular}{|c|c|c|c|c|c|c|c|}
\hline & \multirow{2}{*}{\multicolumn{2}{|c|}{ Articles }} & \multicolumn{5}{|c|}{ Years } \\
\hline & & & 1815 & 1836 & 1860 & \multicolumn{2}{|c|}{1887} \\
\hline Bread & . & - per 4 lbs. & $\begin{array}{ll}s . & d . \\
1 & 4\end{array}$ & $\begin{array}{ll}s . & d . \\
0 & 7 \frac{1}{2}\end{array}$ & $\begin{array}{ll}s . & d . \\
0 & 7 \frac{3}{8}\end{array}$ & $\begin{array}{l}s . \\
0\end{array}$ & \\
\hline Butter & . & - per $1 \mathrm{~b}$. & 12 & $10^{2}$ & $10^{8}$ & 1 & $5^{2}$ \\
\hline Cheese & . & . $\quad$, & $0 \quad 8 \frac{1}{2}$ & $7 \frac{1}{2}$ & $0 \quad 7 \frac{1}{4}$ & 0 & 6 \\
\hline Bacon & . $\quad$. & $"$ & $0 \quad 8 \frac{1}{2}$ & 0 & $9 \frac{3}{8}$ & 0 & 7 \\
\hline Butcber's & meat &, & - & 0 & $0 \quad 7 \frac{3}{4}$ & 0 & 7 \\
\hline Tea. & . $\quad$. & , & $\begin{array}{ll}6 & 0\end{array}$ & 5 & $0^{t}$ & 2 & 3 \\
\hline Sugar & . & , & $0 \quad 9 \frac{1}{2}$ & 0 & $4 \frac{3}{t}$ & 0 & $2 \frac{1}{2}$ \\
\hline Candles & . & . & $0 \quad 7 \frac{1}{2}$ & 06 & $06^{1}$ & 0 & 4 \\
\hline Paraffine & . & - per quart & - & - & - & 0 & $2 \frac{1}{2}$ \\
\hline
\end{tabular}

1 Eastern Tour (1770), rol. iv., pp. 311-326; and Torthern Tour (1771), vol. iv., pp. 293-313.

2 If these prices appear high, it must ve remembered that they are naturally greater when small quantities (as, for instance, ounces of tea) are purchased. 



\section{N D E X.}

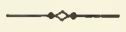

\section{ACR}

ACREAGE, tables of, since 1866 , 264

Agricultural Holdings Acts, 217

Agriculture, Board of, inquiry made in 1816 by, 40,90 ; questions appended to their circular letter, 258; their reports and recommendations on enclosures, 69

Agriculture, early systems of, 1 ; characteristics of, during the Middle Ages, 11 ; pursuit of, by the monks, 14; first revolution in, from tillage to pasture, 17 ; early literature of, 29,248 ; condition of, in the seventeent century, 31 ; general view of, in the eighteenth century, 38-41; obstacles to the advance of, 55 ; second revolution in, from pasture to tillage, aided by manufacturing development, 64 ; effects of enclosure legislation on, 74; stimulus imparted to, by improved transport and communication, 78 ; scientific practice of, in the present century, 86 ; condition of, during the disastrous period of 1812-15, 87 ; progress of, from 1845 to 1873,104 ; publication of statisties relating to, 113 ; the present collapse of, its causes, 115,236 ; its remedies, $125,128,155,237$; effects of monetary disturbances on, 25, 38, 88, 90; French and English, compared, 132; improvements in English, all

\section{BAC}

effected by private enterprise, 148; public teaching of, in France, 149; small number in England of those now occupied in, 158 ; bearing of the tithequestion on, 166 ; education in, required for England, 189, 238; need of a State department of, 195 ; discouraged by present railway rates, 197,238 ; and by unfair incidence of local taxation, 201 ; signs of a third revolution in, to meat and dairy farming, 213 ; tables of statistics relating to, 264

Allotments, labourers', 231 ; table of, 277

Althorp (Lord), his devotion to agriculture, 79

American competition, 121

Arable farming, increased attention to, after the Revolution, 41

- land, first separation of, from pasture, 3 ; crops of, in the Middle Ages, 12

Aristocracy, mediaval, despised farming, 14

Aston Boges, old village customs at, 3 ; cultivation on the old system at, in the present century, 57

Australia, land registration system of, 181

Austria, agricultural education in, 191

BACON (LORD) on manure, 99 


\section{BAK}

Bakewell (Robert), 49 ; his experiments in sheep and cattle breeding, 51

Balks, 5

Belgium, land tenure of, 142

Billyngdon (Thomas) yields his right of common, 27

Blith, advocates drainage, 33 sqq.; quoted, 31, 95, 115

Bolingbroke, his interest in agriculture, 78

Bones first used as manure, 80

Bordars, 10

Bounty system, 41 ; table of amounts, sc., paid under the, 254

Pradley's description of Essex draius, 43

Burke, engaged in an agricultural experiment, 79

Butts, 5

CAIRD (SIR JAMES) recommends high farming, 105 ; obtains agrienltural statistics, 113 ; quoted, 167; his estimate of rentals, 168 note

Camden's description of the Gloucestershire sheep-cots, 49

Cassel, farmers' conference at, 130

Castle Combe, Domesday survey of, 15

Cattle, old notions of breeding, 50 ; Bakewell's attempt to improve, 59 ; Mr. Coke's improvements in feeding and breeding, 80

Cattle plague in eighteenth century, 39 ; risk of, 212

Census, agricultural, for last four decades, 260

Chancer (Geofirey) quoted, 5 note, $9,1 \pm$

Chemistry, services of, to agriculture, 99, 109

Cheviot sheep improved on Bakewell's principles, 52

Church rates, 202 sqq.; tables of, 275

Civil wars, effect of, on agriculture, 32
CoT

Clay lands, drainage of, 95

Climate, deterioration of, after 1764,40

Clover, first successful cultivation of, in England, 32; field cultivation of, by Townshend, 46 ; ignorance respecting, 62

Coinage, condition of, in Tudor times, 25

Coke (Judge) prohibits enclosures at Stratford, 28

Coke (Mr., afterwards Earl of Leicester), his agricultural improvements, 79

Colling's (Chas.) Ketton cattle, 53

Common, rights of, their origin, 8 ; their threefold nature, 18 ; agreements made to extinguish, 19 ; example of their commutation by private contract, 27

Common-field system of husbandry, 3 ; its connection with the disturbances in Skye, 7; extent of its prevalence in 1794 , 56 ; its condemnation and downfall, 65

Commons, enclosures of, commenced, 18; how effected, 26 ; prohibited by law at IVelcombe, 28 ; Board of Agriculture's re. commendations respecting, 70 ; a national necessity, 74 ; attended with suffering to the labourers, 74

Compensation for tenants' improvements, 216

Conquest, the, its effect on agriculture, 8

Corn, bounties on exports of, 41 , 254 ; prices of, 12, 25, 26 . See also Wheat, ke.

Corn laws, earliest, 21 ; table of, 252 ; condition of farming during the period of their greatest stringency, 87 ; abolition of, its effect on farming, 106; social, of Henry VII., 246

Corn-weeding in the Middle Ages, 11

Cotswolds, the, and sheep-cotting, 49 ; common fields in, at the end of the last century, 57 


\section{COU}

County rates, $202 s q q$. ; tables of, 275

Crabbe's description of Suffolk, 43

Crag, a fertiliser used in Suffolk, 43

Crinon (Hector), his description of French peasantry, 136

Crustre of land, 5

Currency questions, connection of, with agricultural depression, 116 ; metallic, of principal countries, 262

DAIRY and livestock farming, 221

Dales and dalesmen, 5

Deanston, Smith's thorough drainage experiment at, 97

Demesne land, 9

Denmark, land laws of, 143

Deron cattle, Scott's anachronism about, 53

Devonshire, absence of village communities in, 3

Dishley, stock-breeding at, 51

Distress between 1812 and1845, 88 ; agricultural, connection of currency questions with, 116 ; selfhelp the best remedy for, 211

Doles, balloting for, 6

Domesclay, New, 15.

Drage, a kind of barley, 13

Drainage, adrocacy of, by Blith, 33 ; works carried out in the fen district in the serenteenth century, 35 ; a doggerel poem denouncing, 35 ; Suffolk and Essex systems of, 43 ; provided for clay farms, 95

Drills, corn, 101

EDGEWORTH (MISS), popularity of her 'Essay on Irish Bulls,' 79

Education, agricultural, in France, $149,190,196$; in other countries, 191; need of, for England, 189

Edward III. establishes the woollen manufacture, 22

Elkington (James), drainage system of, 96

Emigration, 234, 241

\section{FEN}

Enclosures, beginning of, 18; their effect on the peasantry, 20 ; high-handed, 26; an instance from Kennet's 'Parochial Antiquities,' 27 ; extent of, towards the close of the reign of George III., 38 ; profits derivable from, 68 ; recommendations of the Board of Agriculture respecting, 70 ; empowered by Acts of Parliament, 71 ; not followed by depopulation, 72 ; hardships caused to the labouring population by, 73 ; the gain to the nation, 71 ; increase of, in 1810-14, 89 ; table of, since 1700,257

Erskine a student at Holkham, 82 Essex, bad roads of, 60

FAMINE, a frequent result of medireval agriculture, 11

Farm work in feuclal times, 10

Farmers, ignorance of, 59; force of traditional customs among, 61 ; effects of manufacturing development on their condition, 67 ; small freeholding or 5 eomen, suppressed, 83 ; distress among, after the war, 90 ; improved class of, 111 ; popular views of distress among, 115 ; effect of the depression on, 124, 159 ; foreign, present condition of, 129 ; importance of agricultural education to, 194; profession of, 214 ; their want of security for im. provements, 216

Farming, characteristics of, in feudal times, 11 ; increased interest in, in the sixteenth century, 29 ; high, a consequence of free trade, 106 ; future of, 211 ; livestock and dairy, 213, 220

- common-field system of, 3 ; extent to which it prevailed towards the end of the eighteenth century, 56 ; necessity of its abolition, 65

Fens, drainage of the, in the seventeenth century, 34 ; opposition of the fenmen, 35 ; shock- 


\section{FEU}

ing condition of the east and west fens in the succeeding century, 36

Feudalism, agriculture under, 9; emancipation of the land from, 37

Fitzherbert,writings of, 29 ; quoted, $5,18,19,21,45,110$

Flat, an ancient division of land, 4

Flemish wool-workers settled in Engiand, 22

Fleta on trinity fields, 3 ; his estimate of wheat cultivation, 11

Fluke, disease in sheep, Fitzherbert's theary of, 29; extraordinary nostrum for, 59

Foreign competition, 121, 211; felt in otlier countries than England, 161 ; extent of, 211

Fartescue's reasan for the English victaries over the French, 15

Fothers, 5

Fox (C. J.), his interest in agriculture, 79

France, agriculture and peasant proprietorship in, 132 ; peasant life in, 136 ; land tenure of, 141 ; State aid to agriculture in, 149 , 190 ; illustration of its practical working, 196 ; estimates of land distribution in, 158 note; métayage in, 228

Free trade, effect of, on farming, 106

Furlong, an ancient division of land, 4

GAME laws, 215

Gardening, revival of, in the seventeenth century, 31

Garstons, 3

Geology, services of, to agriculture, 100,109

George III., farming tastes of, 79

Germany, depression of farming in, 130; agrarian legislation of, 142; agricultural education in, 191

Gilbert (Dr.), 109, 114

Gold, supply of, its relation to agricultural depression, 119 ; tables showing production of, 261
HUN

Gares, 5

Goschen (Rt. Hon. G. J.) quoted, 160,205

Grain crops in the Middle Ages, 13

Grasses, artificial, culture of, 108

Gresley (Sir T.), cattle-breeding by, 52

Grey (John, of Dilston) establishes farming in Northumberland, 102

Guano, British, 99

HALSBURY (LORD), Land Bill of, $182,184,187$

Hams, 6

Harrison quoted, 13 note, 26 ; his theary of sheep rot, 29

Hartlib, his remedy for fluke, 59 ; his enumeration of manures, 99 note; his notices of agricult ure in the seventeenth century, $31 s q q$. Harvesting in the Middle Ages, 12 Harvests, bad, as a cause of the present depression, 121

Hawsted Manor in the fourteenth century, 11 ; lease covenant respecting manure at, 44

Hedges, prevalence of, in Devonshire, 3 ; construction of, in the eighteenth century, 7; Henry VII., laws of, against pasture farms, 246

Henslow (Professor) shows the use of coprolites for manure, 100

Heraldry, illustration of contempt for farming from, 14

Herefordshire, raads of, 60

Highway rates, $202 s q q$. ; tables of, 275

Holkham, Mr. Coke's enterprise at, 79 ; the sheep-shearings at 82

Hooker (Richard) tending sheep in a common field, 5

Hops, introduction of, into Eng. land, 31

Horses, Suffolk, 42; State encouragement to breeding of, 195

Houghton recommends turnip cultivation, 33

Hundred Years' War, its effect on agriculture, 19 
IMP

IMPORTS, agricultural, since1866, table of, 263

Improvements, compensation for, 216

Ings divided into doles, 6

Ireland, ignorant agricultural practices in, 62

JOHNSTONE (JOHN), his work on drainage, 96

KENNET'S instance of a cession of common rights, 27

King (Gregory), his classification of the population in 1688,158

LABOURERS, agricultural, wages of, in the serenteenth century, 32 ; in the reign of Henry VI., 25 ; table of weekly wages of, 279 ; early attracted to manufacture, 66 ; decline in number of, 111; effect of the depression on, 124, 159; past and present condition of, 224; how to secure small holdings for, 227; lodgings of, 230; allotments for, 231, 277 ; emigration for, $23 \pm$

Lammas Day, land customs of, 5

Land, property in, see Property; agitation, the, 126 ; nationalisation of, 141 ; distribution of, in England and Wales, 155; decreased letting value of, 159 ; transfer of, by registration, 184 ; tables of crops and livestock on, since $1866,26 t-7$

- laws, reform of the, 181

- tax, 202

Landlords, effect of the agricultural depression on, 123, 159; a natural growth, 141 ; number of, in England and Wales, 146, 155; the real gainers by their losses, 160 ; need of agricultural education for, 193

Landowners, small number of, in England, 158

Landshires, 5
MAS

Lavergne (MI. de), his estimate of land division in France, 158 note

Lawes (Sir John) obtains an artificial manure from bonedust, 100 ; his services to agriculture, 114

Leases, farmers', 58 ; Mr. Coke's, at Holkham, 82 ; want of security for improvements under, 216; under Lord Tollemache, 219

Leicester (Earl of). See Coke

Leicester sheep, 51

Liebig, agricultural chemistry of, 99

Lincoln Heath, ralue of enclosures shown on, 70

Lincolnshire, waste condition of, in former times, 44 ; change effected by the adoption of Townshend's system in, 45; value of improved farming shown in, 103

Local Gorernment, abuses of, 208

Local taxation, $201 s q q$.; tables of, 275

Lynches on the Wiltshire and Sussex downs, 2

MACHINES, agricultural, 109

Manors, lords of, origin of their rights, 8 ; division of the land of, after the Conquest, 9 ; as illustrated by the Domesday Book, 15; first enclosures by, 18 ; results of their withdrawal from the agrarian partnership, 20

Manure, bones first used for, 80 ; neglect of, in early agriculture, 98 ; researches of modern chemists on, 99

Markham (Gerrase) quoted, 29, 25; his 'Farewell to Husbandry' quoted, 99

Marling revived by Lord Towns. hend, 45

Marshall, his theory of lynches, 1 ; discorers evidences of the wild-field-grass system, 2 ; his description of the Warwickshire ram, 50 ; quoted, 55, 60, 96

Mascall's theory of sheep rot, 29 


\section{MAS}

Maslin, bread so called, 13

Mieat, prices of, in 1843-6, and 1870-3, 108 note

Merton, statute of, authorises enclosures, 19 ; re-enacted, 22

Métayage, 228

Molesworth (Lord) wishes to make Tusser's poem a class-book, 30

'Monday men' tenants, 16

Money systems of the principal countries, 262

Monks, practice of agriculture by, 14 ; drainage of fen district by, 34

Moreton's leam, 35

Moryson, his 'Itinerary' quoted, 13

NANCY, decision of the Agricultural Congress at, 129

Naseby, late survival of the common-field system at, 57

New Zealand as an agricultural labourers' settlement, 234

Norfolk, Lord Townshend's agricultural improvements in, 44 ; roads of, 60 ; agricultural improvement of, effected by Mr. Coke, 80

Northumberland, farming in, 102

ODAMS, manure of, 100

Oxen, employment of, in farm work, 13

Oxgangs, 5

\section{PARKES (JOSIAH), 98}

Pasture, first separation of, from arable land, 3 ; tillage forsaken for, 22 ; return to, 64 ; legislation against farming, 246

Peasant proprietors, condition of, in France, 132

- proprietorship means extinction of Free Trade, 161 ; the agitation for, 128; not capable of flourishing universally in Britain, 131 ; socially advantageous, 138 ; not to be established by legislation, 139; incompatible with

\section{PUN}

the modern social system, 140 ; co-exists with landlordism on the Continent, 141; need of State aid to, as shown in France, 148

Peasantry, condition and obligations of, in feudal times, 9 ; improved condition of, after 1350 , 14 ; disastrous consequences of sheep-farming to, 23

Pickering, Vale of, late continuance of the common-field system at, 57

Pightels, 5

Plat (Sir Hugh) on the origin of 'setting corn,' 100

Plot, his 'Nat. Hist. of Oxfordslire' quoted, $10,33,45$

Ploughing in medireval times, 10 ; in Suffolk, 43; examples of waste of power in, 61 ; by the tail, 62

Pole, local variations in length of the, 4

Poor law of 1733,39 ; evils of the, during the war period, 75,224

- rates, 202 sqq.; tables of, 275

Population, table of, in 1688, 259

Prices, fall of, in 1819-22, 93

Primogeniture, law of, 181

Property in land, 125; duty of the State to uphold, 147; how to cheapen and facilitate the transfer of, 182

Protection, historical associations of, 87, 163; enconraged gambling, 105 ; wretched system of farming under, 112; the creed of a peasant proprietary, 161 ; working of, abroad, 163 ; impossibility of reviving, in England, 166 ; local taxatiou of, persisting with Free Trade prices, 203; no remedy for the present depression, 211

Provisions, prices of, 281

Prussia, agrarian legislation of, 142; land registration system of, 186 ; agricultural education in, 191

Punches, Suffolk horses so called, 42 
PUS

Pusey (Mr.), his Committee on Agricultural Customs, 103, 107 ; recognises need for tenant right, 112

Pykes, 5

QUARTLEY (Mr.), Devon cattlebreeder, 53

RAFFEISEN'S land-bank system, 227

Railway rates, revision of, in the interests of farmers, 197

Rainfall, increased, in the latter half of the eighteenth century, 40

Raps, 5

Rates, 201 sqq.; tables of, 275

Reed's drainage pipes, 98

Yigs, 5

Roads, bad, an obstacle to agricultural progress, 60

Rogers (Prof. Thorold), his ' Hist. of Agriculture and Prices' quoted, 11

Roots, culture of, 108

Roses, wars of the, their effect on agriculture, 21

Rotliwell, common.field cultivation at, in 1797,57

Rous (John) denounces sheepfarming, 24

Tupee, Indian, reduced valne of, 120

Russia, agricultural education in, 192 note

Rye, cultivation of, in former times, 13

Ryeland sheep, 48

SALISBURY Plain, traces of extinct villages in, 1

Scott (Sir W.), his anachronism about Devon cattle, 53 ; 'Waverley' quoted, 51

Scragg's machine for making drainage pipes, 98

Seebohm, his theory of lynches, 2 ; his inquiries into manorial rights, $\mathrm{S}$
TIT

Serfs, 10

Shakespeare resists an invasion of his rights of common, 28

Sheep, diseases of, early theories as to, 29 ; rot in 1735,39 ; cotting of, 48 ; diseases in, extraordinary nostrum for, 59

Sheep-farming for wool, see Wool; for meat, Bakewell's experiments in, 49

Shot, an ancient division of land, 4

Silver, depreciation of, 120 ; tables showing production of, 261

Skye, crofters of, in 1750, 7

Smith of Deanston, his system of thorough drainage, 97

Smithfield, sizes of cattle and sheep sold at, in 1710 and 1795,53

Sologne district, reclamation of, 153

Southdown sheep improved on Bakewell's principles, 52

Sprengel, agricultural chemistry of, 99

Stewkley, common-field cultivation at, in the end of the last century, 57

Stillingfleet, his knowledge of grasses, 81

Stogoursey, late survival of the dual system of common-field husbandry at, 4,7

Stratford-on-Avon, an enclosure prohibited at, 28

Suffolk, farming in, prior to Lord Townshend's agricultural reform, 42

TAXA'TION, local, 201 ; tables of, 275

Taylor (Samnel), on the use of corn drills, 101

Tenant-right, connection of, with improved farming, 112

Tenants' improvements question, 216

Tillage, reaction from pasture to, 64 ; abandoned for sheep-farming, 22

Tithe question, the, 166 ; to be solved by redemption, 173 
TOL

Tollemache leases, 219

Tomkins's improvement of Here. ford cattle, 53

Torrens Act, 184

Townshend (Lord), his system of husbandry, 42; receives the nickname of Turnip 'Townshend, 47; profitable results of his system, 47

Township described, 3

Tull (Jethro) on the field cultivation of turnips and clover, 46 ; quoted, 62

Tùn, the Anglo-Saxon, 3

Turnips, first successful cultivation of, in England, 32 ; field cultivation of, by Townshend, 46 ; ignorance and prejudice respecting, 62

Turnpike roads, 60

Tusser, his agricultural knowledge, 30 ; quoted, $6,10,31,55,65$

UNITED STATES, agricultural competition of, with England, 121; Central Department of Agriculture in, 196 note

VETERINARY science in France, 152

Village communities, sites of the oldest, 1 ; farming system of, 3 ; imposition of feudal manors on, 8

Villein, status and duties of the, 9 Villeins' land, 9

Vines, ancient culture of, 13

WAGES, rates of, $12,25,32,40,279$

Walpole (Sir R.), his interest in agriculture, 78

Webb (Jonas), his Babraham flock of South-Downs, 52

Webster of Canley, cattle breeding by, 52
YOU

Welcombe, failure of an attempted enclosure at, 28

Westminster, statute of, authorises enclosures, 19

Weston (Sir Richard) succeeds in cultivating turnips and clover, 32

Wheat, unsteady prices of, in the Middle Ages, 12 ; prices of, in the seventeenth century, 32 ; between 1713 and 1764, 39; foreign duties laid on, 41 ; cul. tivation of, established by $M r$. Coke in Norfolk, 80 ; high prices of, in the early years of the present century, 88 ; importation of, from America, 121; not grown profitably under Protection, 163 ; minimum Protection for, 165 ; tables of prices of, in England, 243; in France, Belgium, and Prussia, 274

Wight, Isle of, pasture-farming forbidden in, 246

Wild-field-grass system of husbandry, 2

Wool, culture of, 21 ; its disastrous effects on the lower peasantry, 23 ; exportation of, forbidden, 41; value of English, 48

Worlidge recommends turnip cultivation, 33

Württemberg, agricultural education in, 192

YARDLANDS explained, 57

Young (Arthur), outline of his career, 62 ; denounces the openfield system, 65 ; his argument against small farmers, 74 ; his agricultural estimates for 1771 , 269 ; his calculations of wages and prices for 1771, 2S1; quoted, $32,55,58,59,60,70,72,73,79$, $95114139169,215,228,232$ 


\section{THE BADMINTON LIBRARY. \\ EDITED BY}

THE DUKE OF BEAUFORT, K.G. AND A. E. T. WATSON.

HUNTING. By the Duke of Beaufort, K.G. and Mowbray MLorris. With Contributions by the EarL of Suffolk and Berkshire, Rev. E. W. L. Davies, Digby Collins, and Alfred E. T. Watson. With Coloured Frontispiece and 53 Illustrations on Wood by J. Sturgess, J. Charlton, and Agnes M. Biddulph. Fourth Edition. Crown 8ro. 10s.6d.

FISHING. By H. Cholnondelem-Penneld. With Contributions by the Marquis of Exeter, Henry R. Francis, M.A. Hajor John P. Traherne, G. Christopher Davies, R. B. Marston, \&t.

Vol. I. Salmon, Trout, and Grayling. With Frontispiece, and 150 Illnstrations of Tackle, \&c. Third Edition. Crown 8vo. 10s. 6d.

Vol. II. Pike and other Coarse Fish. With Frontispiece and 58 Illustrations of Tackle, \&c. Third Edition. Crown 8vo.10s. $6 d$.

RACING AND STEEPLE-CHASING. RAcING: By the Earl of Suffolk and Berkshire and W. G. Craven. With a Contribution by the Hon. F. Lawlex. Steeple-chasing: By Arthur Coventry and Alfred E. T. Watson. With Coloured Frontispiece and 56 Illustrations by J. Sturgess. Second Edition. Crown 8vo. 10s. 6d.

Shooting. By Lond Walsingham and Sir Ralph PayneGallwex, Bart. With Contributions by Lord Lovat, Lord Charles Lennox Kerr, the Hon. G. Lascelles, and A. J. Stuart-Wortiey. With 21 Full-page Illustrations and 149 Woodcuts in the Text by A. J. Stuart-Wortefy, Harper Penniggton, C. Whymper, J. G. Millais, G. E. Lodge, and J. H. Uswald Brown.

Vol. I. Field and Covert. Second Edition. Crown 8vo. 10s. 6d.

Vol. II. Mfoor and Marsh. Second Edition. Crown 8vo. 10s, 6 $d$.

CYCLING. By Viscount Bury, K.C.M.G. and G. Lacy Hillier. With 19 Plates and 61 Woodeuts in the Text by Viscount Bory and Joseph Pennell. Crown 8to. 10s. 6d.

aTHLETICS AND FOOTBalL. By Montague Shearman. With an Introduction by Sir Richard WeBstkR, Q.C. MI.P. and a Contribution on Paper Chasing by Walter Rye. With 6 Fullpage Illustrations and 45 Woodcuts in the Text from Drawings by Stanley Berkeley, and from Instantaneous Photographs by G. Mitchell. Crown 8ro. $10 s .6 d$.

IN PREPARATION.

RIDING.
DRIVING.
EENCING.
BOATING.

CRICKET. TENNIS, \&c. GOLF, \&c. YACHTING.

London: LONGMANS, GREEN, \& CO. 


\section{BOOKS FOR THE COUNTRY.}

A BOOK on ANGLING; or, Treatise on the Art of Fishing in every branch, including full Illustrated Lists of Salmou Flies By Francis Francis. Post 8ro. Portraits and Plates $15 s$.

The FLY-FISHER'S ETYMOLOGY. By Alfred Rovalds. With 20 Coloured Plates. 8vo. 14s.

The SEA-FISHERMAN; comprising the Chief Methods of Hook and Line Fishing in the British and other Seas, and Remarks on Nets, Boats, and Boating. By J. C. Wircocks. Profusely Illustrated with Woodeuts of Leads, Baited Hooks, \&c. New and Cheaper Edition (the Fourth). Crown 8vo. 6s.

The SCIENCE of AGRICULTURE. By Frederick James LLoyn, Lecturer on Agriculture, King's College, London. 8ro. 12s.

ARTIFICIAL MANURES; their Chemical Selection and Scientific Application to Agriculture. By Georges ViLle. Translated and edited by W. Crookes, F.R.S. With 31 Plates. Sro. $21 s$.

HOW to MAKE the LAND PAY; or, Profitable Industries connected with the Land. By H. P. Dexster, M.A. Crown 8 ro. 5 s.

A TREATISE on the DISEASES of the OX; being a Manual of Borine Pathology specially adapted for the use of Veterinary Practitioners and Stndents. By J. H. STEEL M.R.C.V.S With 2 Plates and 117 Woodents. 8ro. $15 s$.

A. TREATISE on the DISEASES of the DOG; being a Maunal of Canine Pathology. Especially adapted for the Use of Veterinary Practitioners and Students. By Johs Henre Steec, II.R.C.V.S. With 88 Illustrations. 8 ro. 10s.6d.

HORSES and STABLES. By Major-General Sir F. FitzTygram, Bart. With 19 pages of Illustrations. 8ro. $5 s$.

The HORSE. By William Youatr. Revised and Enlarged by W. WATSON, M.R.C.V.S. 8ro. Woodents. $7 s .6 d$.

The DOG. By Wilitam Youatt. Revised and Enlarged. 8ro. Woodcuts, $6 s$.

The DOG in HEALTH and DISEASE. By 'Stonehenge.' With 84 Wood Engravings. 870. 7s.6d.

The GREYHOUND. By 'Stonehenge.' With 25 Portraits of Greyhounds, \&e. Square crown 8ro. 15s.

London: LONGMANS, GREEN, \& CO. 


\section{JUIVE 1883 .}

\section{GENERAL LISTS OF WORKS PUBLISHED BY}

\section{MIEssrs. LONGMANS, GREEN, \& CO. LONDON AND NEW YORK.}

HISTORY, POLITICS, HISTORICAL MEMOIRS, \&C.

Abbey's The English Church and its Bishops, 1700-1800, 2 vols. 8vo. 24s. Abbey and Orertola's English Charch in the Eighteenth Century. Cr. 8vo. 7s, 6d. A ruold's Lectures on Modern History. 8vo. 7s, 6d.

Bagwell's 1reland under the Tutors. Vols. 1 and 2. 2 vols. 8vo. 32s.

Ball's The Reformed Church of Ireland, 1537-1886. 8vo. 7s. $6 \mathrm{~d}$.

Boultbee's History of the Church of England, Pre-Reformation Period. 8vo.15s.

Buckle's History of Civilisation. 3 vols. crown 8vo. 24s.

Canning (George) Some Official Correspondence of. 2 vols. 8 vo. $28 s$.

Cox's (Sir G. W.) General History of Greece. Crown 8vo. Mlaps, 7.s. $6 d$.

Creighton's Papacy during the Reformation. 8vo. Vols. 1 \& 2,32s. Vols. $3 \& 4,24 s$.

De Tocqueville's Democracy in America. 2 vols. crnwn 8vo. 16s.

Doyle's English in America : Virginia, Maryland, and the Carolinas, 8vo. 18s.

Epochs of Ancient History. The Puritan Colonies, 2 vols. 8vo. 36s. Sankey, M.A. With Maps. Fep. $8 \nabla 0$. price $2 s, 6 d$. each.

Beesly's Gracchi, Marlus, and Sulla.

Capes's Age of the Antonines. - Early Roman Empire.

Cox's Athenian Empire. - Greeks and Persians.

Curteis's kise of the Macedonian Empire. Epochs of Modern History. Edited by C. Colbeck, M.A. With Maps. Fcp. 8ro. 2s. $6 d$. each.

Church's Beginning of the Mridule Ages.

Cox's Crusades.

Creighton's Age of Elizabeth.

Gairdner's Houses of Lancaster and York.

Gardiner's Puritan Revolution. - Thirty Years' War.

- (Mrs.) Freuch Revolution, 1789-1795.

Hale's Fall of the Stuarts.

Johnson's Normans in Europo.

Inne's Rome to its Capture by the Gauls.

Merivale's Roman Triumvirates.

Sunkey's Spartan and Thebau Supremacies.

Smith's Rome and Carthage, the

mith's Rome and Carthage, the
Punic Wars.

Longman's Frederick the Great and the Seven Years' War.

Luvilow's War of American Independence.

M'Carthy's Epoch of Reform, 18301850.

Moberly's The Early Tudors.

Blorris's Aye of Queen Anne. - The Early Hanoveriana.

Seebohm's Protestant Revolution.

Slubbs's The Early Plantagenets.

Warburton's Elward II1.

Epochs of Ohurch History. Elited by the Rev. Mandell Creighton, M.A. Fcp. 8vo. price 2s, 6r. each.

Brodrick's A History of the University of Oxford.

Carr's The Church and the Roman Empire.

Hunt's England and the Papacy.

Mnllinger's The University of Cambridge.

Orerton's The Fringelical Revival in the Eighteenth Century.

Perry's The Reformation in Eugland.

* Other Volumes in preparation.

lurnmer's The Church of the Farly Fathers.

Stephens' Hildebrand and his Times.

Tozer's The Ohurch and the Eastern Empire.

Tucker's The English Charch in other Laurls.

Wakeman's The Church and the Puritans.

LONGMIAS, GREEN, \& CO., London and New York. 
Freeman's Historical Geography of Europe. 2 vols. 8vo. 31s. $6 d$.

Froude's English in Ireland in the 18th Century. 3 vols. crown Sro. 18 s.

- History of England. Fopular Edition. 12 vols. crown 8ro. 3s.6 $\boldsymbol{d}_{\text {. each. }}$ Gardiner's History of England from the Accession cf James I. to the Outbresis of the Civil War. 10 vols, crown $8 \mathrm{ro} .603$.

- History of the Great Civil War, 1612-1619 (3 vols.) Vol. 1, 1642-1614, $8 \mathrm{vo} .21 \mathrm{s.}$

Qreville's Journal of the Reigns of King George IV., King William IV., and Queen Victoria. Cabinet Edition. 8 vols, crown 8 ro. 6 s, each.

Historio Towns. Edited by E. A. Freeman, D.C.L. and the Rev. William Hunt, I.A. With Maps and Plans, Crown 8vo. 3s. 6d. each.

Iondon. Iy W. E. Loftie.

Exeter. By E. A. Freeman.

Cinque Ports. By Montagu Burrows.

Bristol. By the Rev. W. Munt. Oxford. Ey the Rev. C. W. Boase. Colchester. By the Rev, E. O. Cutts.

Locky's History of England in the Eighteenth Century. Vols. 1 \& 2, 1700-1760, 850. 36s. Vols. 3 \& 4, 1760-1784, 8vo. 36s. Vols. $5 \& 6,1784-1793,36 s$.

- History of Europenn Morals. 2 rols. crown 8vo. 16s.

- $\quad$ - Rationalism in Europo, 2 vols. crown 8vo. 16s.

Longman's Life and 'Times of Edward III. 2 vols. 8 vo. 28s.

Macaulay's Complete Works. Library Edition. 8 vols. 8 ro. £5. $5 s$.

- - - - Cabinet Edition, 16 vols. crown 8vo. £4. 16 s.

- History of England :-

Student's Edition. 2 vols. cr. 8 ro. 12s. $\mid$ Cabinet Idition, 8 vols. post 8vo. 48. People's Edition. 4 vols, cr. 8vo.16s. Library Edition. 5 vols. 8 vo. \&4.

Macanlas's Critical and Historical Essays, with Lays of Ancient Rome In One Volume:-

Authorised Edition. Cr. 8vo. 2s,6d.| Popular Edition. Cr. 870. 2s. 6d. or $3 s, 6 d$. gilt edges.

Macaulay's Critical and Historical Essays :-

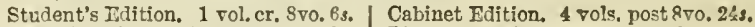
People's Edition. 2 vols, cr. 8 ro. 8s. Library Edition. 3 vols. \&vo. $36 s$.

Miacaulay's Speeches corrected by Himself. Crown 8vo. 3s. $6 d$.

Malmesbury's (Earl of) Memoirs of an Ex-Minister. Crown 8vo. 7s. $6 d$. Nay's Constitutional History of England, 1760-1870. 3 vols. crown Sro. 18 s.

- Democracy in Earope. 2 vols. 8vo. 32s.

Arerivale's Fall of the Roman Republic. 12mo. $78.6 d$.

- General History of Rome, B.C. 753-A.D. 476. Crown 8vo. 7s. 6d.

- History of the Romans nuder the Empire. 8 vols. post 8vo. $48 \mathrm{~s}$.

Nelson's (Lord) Letters and Despatches. Edited by J. K. Laughten. 8тo. 163.

Fears' The Fall of Constantinople. 8ro. 16s.

Richey's Short History of the Irish People. 8vo. 14s.

Baintsbury's Manchester : a Short History. Cromn 8ro. 3s. $6 d$.

Seebohm's Oxford Reformers-Colet, Erasmus, \& \rore. 8vo. 14s.

Short's History of the Church of England. Crown 8vo. 7s. $6 d$.

Smith's Carthage and the Carthnginians. Crown 8vo. 10s. 6 d.

Taylor's Manual of the History of India. Crown 8vo. 7s, $6 d$.

Todd's Parliamentary Government in England (2 vols.) Vol. 1, 8ro. 21s.

Tuttle's History of Prussia under Frcderick the Great, 1740-1756. 2 vols. crown 8 vo. 18 s.

LONGMINS, GREEN, \& CO., London and Now York. 
Vitzthum's St. Petersburg and London, 1852-1864. 2 vols. 8vo. 30s.

Walnole's History of England, frcm 1815. 5 vols. 8vo. Vols. 1 \& 2, 1815-1832, 36s, Tol. 3, 1832-1841, 18s. Vols. 4 \& 5, 1841-1858, 36s.

Wglie's History of Ençland ander Henry IV. Vol. 1, crown 3vo. 10s, 8d.

\section{BIOGRAPHICAL WORKS}

Armstrong's (E. J.) Life and Letters. Edited by G. F. Armstrong. Fcp. 8vo. 7s.6d. Buron's Life and Letters, by Spedding. 7 vols. 3ro. .4. $\mathrm{ks}$

Bagebot's Biographicni Studies. 1 vol. 8vo. 12s.

Cariyle's Lito, by J. A. Fronde. Vols. 1 \& 2, 1795-1835, 8vo. 82ง. Vols. 3 \& \&, 1834-1881, 3ro. 325.

- (Mrs.) Letters and BIemorials. 3 vols. 8 vo. $36 s$.

Dojle (Sir F. H.) Reminiscences and Opinions. 8ro. 16s.

Xnglish Worthies. Edited by Andrew Lang. Crown 8ro, each 1s. Eewed; $1 s, 6 d$. cloth.

Charles Darwin. By Grant Allen. Steele. By Austin Dobson.

Shaftesbury (The First Earl). By Ben Jonson. By J. A. Syuionds. H. D. 'Traill.

Admiral Blake. By David Hannay.

Mariborough. By Geo. Saintsbury.

George Canning. By Frank H. Hill. Claverhouse. By Mowbray Morris.

Fox (Charles James) The Early History of. By Sir G. O. Trevelyan, Bart. Crovn 8 ro. $6 s$.

Froude's Cæsar: a Sketch. Crown 8vo. 6s.

Ifwniton's (Sir W. R.) Life, by Graves. Vols. 1 and 2, 8vo. 15s. each.

Invelock's Life, by Marshman. Crown 8vo. 3s. $6 . t$.

Jenkin's (Fleeming) Papers, Literary, Scientific, \&c. With Memoir by R. I. Stevenson. 2 vols. 8 vo. $32 s$.

Laughton's Studies in Naval History. 8ro. 10s.6d.

Macaulay"s (Lord) Life and Letters. By his Nephew, Sir G. O. Trevelyan, Bart. Popular Edition, 1 vol. crown 8vo. 6s. Cabinet Edition, 2 vols. post 8vo. 12s. Library Edition, 2 vols. 8vo. $36 s$.

Mendelssohn's Letters. Translated by Lady Wallace. 2 vols. cr. 8vo. 58, eaoh. Muller's (Max) Liographical Essays. Crown 8vo. 7s.6d.

Newman's Apologia pro Vitâ Suâ. Crown 8vo. 6s.

Pasteur (Louis) His Life and Labours. Crown 8vo. 7s. 6d.

Shakespeare's Life (Outlines of), by Halliwell-Phillipps. 2 vols. rojal 8vo. 10s. 6d.

Southey's Correspondence with Caroline Bowles. 8vo. 14s.

Siephen's Essays in Eculesiastical Biography. Crown 8vo. 7s. 6d.

Trylor's (Sir Henry) Correspondence. 8vo. 16s.

Wellington's Life, by Gleig. Crown 8 vo. 6s.

\section{MENTAL AND POLITICAL PHILOSOPHY, FINANCE, \&C.}

Ariam's Public Debts ; an Essay on the Science of Finance. 8vo, 12s.6d.

Amos's Vlew of the Science of Juxisprudenco. 8vo. 18s.

- Primer of the English Constitution. Crown 8vo. 6s.

Bacon's Essays, with Annotations by Whately. 8vo. 10s, $6 d$.

- Works, edited by Spedding. 7 vols. 8vo. 73s. 6 d.

Bagehot's Economic Studies, edited by Hutton. 8vo. 10s, $6 d$.

- The Postulates of English Political Eloonomy. Crown 8ro. 2s. 6..

LONGMANS, GREEN, \& CO., London and New York. 
Bain's Logic, Deductive and Inductive. Crown 8vo. 10s. $6 d$.

PART I. Deduction, 4s. | PART II. Induction, 6s, 6d.

- Mental and Mforal Science. Crown 8vo. 10s.6d.

- The Senses and the Intellect. 8vo. 15s.

- The Emotions and the Will. 870, 15s.

Crozier's Civilisation and Progress. 8ro. 5s.

Crump's Short Enquiry into the Formation of English Political Opinfon. 8ro. 7s.6d.

Dowell's A History of Taxation and Taxes in England. 8ro. Vols. 1 \& 2, 21s. Vols. 3 \& 4, 21 s.

Green's (Thomas Hill) Works. (3 vols.) Vols, 1 \& 2, Phiosophical Works. 8vo. 168, each.

Hume's Essays, edited by Green \& Grose. 2 vols, 8vo. 28 s.

- Treatise of Human Nature, edited by Green \& Grose. 2 vols. 87o. 28.

Kirkup's An Enquiry into Socialism. Orown 8 ro. 5 s.

Ladd's Elements of Physiological Psychology. 8vo. 21s.

Lang's Custom and Myth : Studies of Early Usage and Belief. Crown 8vo.78,6d.

- Mfyth, Ritual, and Religion, 2 vols. crown 8ro. 21s.

Leslie's Essays in Political and Moral Philosophy. 8ro. 10s, 6d. ,

Lewes's History of Philosophy. 2 vols. 8vo. 32s.

Lubbock's Origin of Civilisation. 8vo. 18s.

Macleod's The Elements of Economics. (2 vols.) Vol. 1, cr. 8ro. 7s. 6d. Vol. 2, Part I. cr. 8vo. 7s. $6 d$.

- The Elements of Banking. Crown 8ro. 5 s.

- The Theory and Practice of Banking. Vol. 1, 8vo. 12s. Vol. 2, 14s.

Mrax Mrtiller's The Science of Thought. 8vo. $21 \mathrm{~s}$.

Mill's (James) Analysis of the Phenomena of the Human Mind, 2 rols. 8vo. 23s. Mill (John Stuart) on Representative Government. Crown 8vo. 2s.

\begin{tabular}{|c|c|c|c|}
\hline - & - & Liberty. Crown 8ro. 1s. 4a. & \\
\hline- & - & Examination of Hamilton's Philosophy. 870.16s. & \\
\hline & - & Logic. Crown 8 ro. 5 s. & \\
\hline- & - & $\begin{array}{l}\text { Principles of Political Economy. } 2 \text { vols. } 8 \text { vo. } 30 \text { s. } \\
\text { Edition, } 1 \text { vol. crown } 8 \nabla 0.5 \text { s. }\end{array}$ & People's \\
\hline & - & Ctilitarianism. 8vo. 5s. & \\
\hline & - & Three Essays on Religion, \&c. 8 ro. 5s. & \\
\hline
\end{tabular}

Mulhall's History of Prices since 1850. Crown 870. 6s.

Sandars's Institutes of Justinian, with Euglish Notes. 8vo. 18.

Seebolum's English Fillage Community. 8vo. 16s.

Sully's Outlines of Psychology. 8vo. 12s,6d.

- Teacher's Handbcok of Psychology. Crown 8vo. 68. 6d.

Swinburne's Picture Logic. Post 8vo. 5s.

Thompson's A System of Psychology. 2 vols. 8vo. 36s.

- The Problem of Svil. Svo. 10s. 6 d.

- The Religious Sentiments of the Human Mrind. 8vo. 7s.6d.

Thomson's Outline of Neceskary Laws of Thought. Crown $8 \mathrm{vo} .6 \mathrm{~s}$.

Twiss's Law of Nations in Time of War. 8vo.21s.

Webb's The Veil of Isis. $8 \mathrm{vo}$. $103.6 d$.

Whately's Elements of Logic. Crown 8vo. 4s. $6 d$.

- - Rhetoric. Crown 8vo. 4s. 6d.

Wy ylic's Labour, Leisure, and Lnxury. Crown 8vo. 6s.

Zeller's History of Eclecticism in Grcck Philosophy. Crown 8vo. 10s. 6d.

- Plato and the Older Academy. Crown 8vo. 18s.

LONGMANS, GREEN, \& CO., London and New York. 


\section{General Lists of Works.}

Zeller's Pre-Socratic Schools. 2 vols. crown $8 \mathrm{vo}, 30$ s.

- Sccrates and the Socratic Schools. Crown 8ro. 10s. 6d.

- Stoics, Epicureans, and Sceptics, Crown 87o. 15s.

- Outlines of the Histery of Greek Philosophy. Crown 87o. 10s. 5d.

\section{MISCELLANEOUS WORKS.}

A. K. H. B., The Essays and Contributions of. Crown 8 vo.

Autumn Holidays of a Coantry Parson. 3s.6d.

Clianged Aspects of Cnchanged Truths. 3s. $6 d$.

Common-Place Philosopher in Town and Country. 3s. $€ d$.

Critical E:says of a Country Parson. 3s. $6 a$.

Counsel and Comfort spoken from a City Pulpit. 3s. $6 d$.

Graver Thoughts of a Country Parson. Three Series, 3s.6d. each.

Landscapes, Churches, and Moralities. $3 s .6 d$.

Leisure Hours in Town. 3s. 6u. Lessons of Mfiddle Age. 3s.6d.

Our Homely Comed 5 ; and Tragedy. 3s. $6 d$.

Our Little Life. Essays Consolatory and Domestic. Two Series, 3s.6d.

Present-day Thoughts, $3 s .6 \mathrm{~d}$.

[esch.

Recreations of a Country Parson. Three Series. 3s, 6d, each.

Seaside Musings on Surdays and Week-Dars. 3s. $6 d$.

Sunday Afternoons in the Parish Church of a University City. 3s. 6 d. Armstrong's (Ed. J.) Essays and Sketches. Fcp. 8vo. 5s.

Arnold's (Dr. Thomas) Miscellaneous Works. 8vo. 7s. 6d.

Bagehot's Literary Studies, edited by Hutton. 2 vols, 8 vo. 28 s.

Beaconsfield (Lord), The Wit and Wisdom of. Crown 8ro. Is. boards; 1s. $8 d$. cl.

Farrar's Language and Langunges. Crown 8 80.68.

Froude's Short Studies on Great Subjects. 4 vols. crown 8ro. 24s.

Huth's The Marriage of Near Kin. Royal 8vo. 21s.

Lang's Letters to Dead Authors. Fcp. 8ro. 6s. 6d.

- Books and Bookmen. Crown 8vo. 6s, 6d.

Macsulay's Miscellaneous Writings, 2 vols. 8ro. 21s. 1 rol, crown 8vo. $4 s .62$.

- Miscellaneous Writings and Speeches. Crown 8 ro. $6 s$.

- Miscellaneous Writings, Speeches, Lays of Ancient Rome, \&c. Cabinet Edition, 4 vols, crown $8 \mathrm{vo}$, $\$ 4 s$.

- Writings, Selections from. Crown 8vo. $6 \mathrm{~s}$.

Mrax Mliller's Lectures on the Science of Language. 2 vols. crown $8 \mathrm{vo} .16 s$.

- - Lectures on India. 8vo. 12s. fid.

- - Biographies of Words and the Fome of the Aryas. Crown 8vo.7s.62. Oliver's Astronomy for Amateurs. Crown 8vo. $78.6 d$.

Proctor's Chance and Luck. Crown 8vo. 5s.

Smith (Sydney) The Wit and Wisdom of. Crown 8vo. 1s. boards; 1s. 6d. cloth.

\section{ASTRONOMY.}

Herschel's Outlines of Astronomy. Square cromn 8vo, $12 \mathrm{~s}$.

Prcetor's Larger Star Atlas, Folio, 15s, or Maps onl5, 12s. $6 d$.

- New Star Atlas. Crown 8ro. 5s.

- Light Seience for Leisure Hours. 3 Series. Crown 8ro. 5s. each.

- The Moon. Crown 8vo. 6s.

- Other Worlds than Ours. Crown 8vo. 5s.

- Studies of Venus-Transits. 8vo. 5s.

- Orbs Around Us. Crown 8ro. 5s,

- Universe of Stars. 8vo. 10s.6\%.

- Old and New Astronomy. 12 Parts. 2s. 6d. each. (In course of publication.)

Webb's Celestial Objects for Common Telescopes. Crown 8 ro. $9 s$.

LONGLIANS, GREEN, \& CO., London and New York. 


\section{THE 'KNOWLEDGE' LIBRARY.}

Edited by Richard A. PRoctor.

How to Play Whist. Crown 8vo. $5 \mathrm{~s}$. Home Whist. $16 \mathrm{mo}$. $1 \mathrm{~s}$.

The Poetry of Astronomy. Cr. 5vo. 6s. Nature Studies. Crown 8vo. 6s.

Leisure Resdings. Crown 8vo, $6 s$.

The Stars in their Seasona. Imp. Svo. 5s. Ifyths and Marvels of Astronomy. Crown 870.6s.

Pleasant Ways in Science. Cr. 8vo. Es. Star Primer. Crown 4to. 28.6d.

The Seasons Pictured. Demy 4to. 5. Scrength and Happiness. Cr. 8vo. 5s. Rough Weys made Smooth. Cr.8vo.5s. The Expanse of Heaven. Cr. $3 \nabla 0,5 s$. Our Place s.mong Infinitics. Cr. 8vo. 5 s. The Great Pyramid. Cr.8vo. 6s.

\section{CLASSICAL LANGUAGES AND LITERATURE.}

Esschylus, The Eumenides of. Text, with Metrical English Translation, by J.F. Davies. 8vo.7s.

Aristophnnes' The Achamians, transiated by R. Y. Tyrrell. Crown 8vo. 2s. 6d. Aristotle's The Ethics, Text and Notes, by Sir Alez. Grant, Bart. 2 vols. 87o. 32s.

- The Nicomachean Ethics, transiated by Williams, crown 8vo. 7s. 6a.

- The Politics, Books I. III. IV. (VII.) with Translation, \&ac. by Bolland and Lang. Crown 8 vo. $7 s .6 a$.

Becker's Charicles and Gallus, by Metealfo. Posi 8vo. $7 s .6$ a. each.

Cicero's Correspondence, Text and Notes, by R. \. Ty̆rrell. Vols. 1 \& 2, 8 จ०. 12s. each.

Liahaffr's Classical Greek Liternture. Crown 8ro. Fol. 1, The Poets, 7s. $6 d$. Vol. 2, The Prose Writers, is. $6 d$.

Plato's Parmenides, with Notes, cc. by J. Mraguire. 8vo. 7s. 6d.

Virgil's Works, Latin Text, with Conmertar, he Kennedy. Crown 87o. 10s. 6d.

- Eneid, translated into English Verse, iy Conington. Crown 8ro. 9.,

- - - - - —. by W.J. Thornhill, Cr. 8vo.7s.ed.

- Poems, - - - Prose, by Conington. Crowz 8ro. 9s.

Witt's Mythy of Hellas, trauklatea by F. M. Iounghusband. Crown 8vo. 3s. 6d.

- The Trojan War, - - Fep. 8vo. 2s.

- The Wanderings of Ulyases, - Crown 8vo.3s.6d.

NATURAL HISTORY, ROTANY, \& GARDENING.

Dixon's Rural Bird Iife. Crown 8vo. Mllustratious, 5 s.

Hartwig's Aerial World, 8vo. 10s. 6d.

- Polar World, Svo. 10s.6d.

- Sea and its Living Wonder. 8ro. 10s.6d.

- Subterranean World, 8vo. 10s.6d.

- Tropical World, Sro. 10s. 6 d.

Iindley's Treasury of Botany. 2 rols. Ícp. 8vo. 12s.

Loudon's Encyclopædia of Gardening. 8vo. 21s.

- - Plants. 8vo.42s.

Rivers's Orchard House. Crown 8vo. 5s.

- Miniature Fruit Garden. Fcp. 8ro. 4s.

Stanley's Familiar History of British Dirds. Crown 8:0. 8 .

Wood's Bible Animals. With 112 Viguettes, 8vo. 103. 6a.

- Homes Without Hands, 8vo. 10s. 6i.

- Insects Abroaà, 8ro. 10s. 6d.

- Horse and Man. 8ro. 14s.

- Insects at Honno. With 700 Lilustrations. 8vo, 10s. 6d.

JONGMANS, GREE:i, \& CO., London and New Iork. 
Wood's Out of Doors. Crown 8 ro. 5s.

- Petland Revisitel. Crown 8ro. 7s,6\%

- Strange Dwellings. Crowu Svo. 5̃s. Popular Edition, 4to. 6d.

\section{CHEMISTRY ENGINEERING, \& GENERAL SCIENCE.}

Arnott's Elements of Physics or Natural Philosophy. Crown 8vo. i2s. $6 d$. Barrett's English Glees and Part-Songs: their Historical Development. Crown 8ro. $i s .6 d$.

Bourne's Catechism of the Steam Engine, Crown 8vo, 7s, $6 d$.

- Handbook of the Steam Engine. Fep. 8vo.9s.

- Receut Improvements in the Steam Eugive. Fcp. 8vo. 68.

Buckton's Our Dwellings, Healthy snd Unhealthy. Crown 5 ro. 3s. $6 d$. Clerk's The Gas Eugine. With Illustrations. Crown 8 vo. $7 s .6 d$.

Cloda's The Story of Creation. Illustrated. Crown 8vo. $6 s$.

Crookes"s Select Methods in Chemical Avalysis. 8vo. 24s.

Culley's Handbook of Practical Telegraphy. 8vo. 16s.

Fairbairn's Useful Information for Engineers. 3 vol̈. crown 8vo. 31s, $6 d$.

- Mills and Millwork. 1 vol. 8 vo. 25s.

Forbes' Lectures on Electricity. Crown Svo. 5 s.

Galloway's Principles of Chemistry Practically Tanght. Crown 8vo. 6s. 6a.

Ganot's Elementary Treatise on Physics, by Atkinson. Large crown 870. 16.

- Natural Philosophy, by Atkinson. Crown 8ro. 7s.6d.

Grove's Correlation of Physical Forces. 870. 15s.

Haughton's Six Lectures on Physical Geography. 87o. 15s.

Helmholtz on the Sensations of Tone. Royal 8vo. 28s.

Helmholtz's Lectures on Scientific Subjects. 2 vols. crown 8 vo. 7s. 6 d. erch.

Hudson and Gosse's The Rotifera or 'Wheel Animalcules:' With 3f Coloured Plates. 6 parts. 4 to. 10 s. 6 d. each. Complete, 2 vols. 4 to. $£ 3.10 s$.

Hullah's Lectures on the History of Modern Music. 8vo. 8s. $6 \mathrm{~d}$.

- Transition Period of MIusical History. 8vo. 10s.6d.

Jackson's Aid to Engineering Solution. Royal Sro. 21s.

Jago's Inorganic Chemistry, Theoretical and Practical. Fcp. 8vo. 2s.6d.

Kolbe's Short Text-Eook of Inorganic Chemistry. Crown 8vo. 7s.6 6 .

Lloyd's Treatise ou Magnetism. 8จo. 10s. 6d.

Macalister's ZoologJ and Morphology of Vertebrate Animals. 8vo. 10s.6d

Liacfarren's Lectures on Ilarmony. 8vo. 12s.

- Addresses and Lectares. Crown 8vo. 6s. 6d.

Martin's Navigation and Nautical Astronomy. Royal 8ro. 18s.

Meyer's Modern Theories of Chemistry. 8vo. 18s.

Willer's Elements of Chemistry, Theoretical and Practical. 3 vols. 8vo. Part I. Chemical Physics, 16s. Part II. Inorganic Chemistry, 24s. Part IrY. Organio

Chenistry, price 3is. $6 d$.

Mitchell's Manual of Practical Assajing. 8ro. 31s,6d.

- Dissolution and Evolution and the Science of Medicine. 8ro.16s,

Noule's Hours with a Three-inch Telescope. Crown 8vo. 4 s. $6 a$.

Northcott's Lathes and Turning. 870. 183.

Owen's Comparative Anatomy and Physiology of the Tertebrato Animals. 3 rols. 8 vo. $73 s, 6 d$.

Piesse's Art of Perfumery. Square crown 8ro. 21s.

LONGMANS, GREEN, \& CO., London and New Tork. 
Richardson's The Health of Nations; Works and Life of Edwin Chad wick, C.B. 2 rols. $8 \mathrm{vo} .28$ s.

- The Commonhealth; a Series of Essajs. Crown 8vo. 6.s.

Schellen's Spectrum Analysis, 8vo. 31s, $6 d$.

Scott's Weather Charts and Storm Warnings. Crown 8vo. 6s.

Sennett's Treatise on the Marine Steam Eugine. 8vo. $21 \mathrm{s.}$

Smith's Air and Kain. 8vo. 24s.

Stoney's The Theory of the Stresses on Girders, \&c. Royal Svo. 30.

Tilden's Practical Chemistry. Fep. 8 ro. 1s. $6 d$.

Tyndall's Faraday as a Discoverer. Crown 8vo. 3s. $6 d$.

- Floating Matter of the Air. Crown 8vo. 7s,6d.

- Frrgments of Science. 2 rols. post Sro. 16 s.

- Heat a Mode of Motion. Crown 8vo. 12s.

- Lectures on Light delivered in America. Crown 8vo. 5 s.

- Lessons on Electricity. Crown 8ro. 2s.6d.

- Notes on Elcctrical Phenomena. Crown 8vo. 1s. sewed, 1s. 6?. cloth.

- Notes of Lectures on Light. Crown 8vo. 1s. sewed, 1s, 6 d. cloth.

- Researches on Diamagnetism and Mrague-Crsstallic Action. Cr. 8ro. $12 s$.

- Sound, with Frontisplece and 203 Woodcuts. Crown 8vo. 10s. 6d.

Unwin's The Testing of Mraterials of Construction. Inlustrated. 8ro. 21s.

Wattg' Dictionary of Chemistry. New Edition (4 rols.). Vol. 1, 8vo. 42s.

Wilson's Manual of Health-Science. Crown 8vo. 2s, $6 d$.

\section{THEOLOGICAL AND RELIGIOUS WORKS.}

Amold's (Rev. Dr. Thomas) Sermons. 6 vols. crown 8 ro. 5s. each.

Boultbee's Commentary on the 39 Articles. Crown 8 ro. 6 s.

Browne's (Bishop) Exposition of the 39 Articles. 8vo. $1 \mathrm{Es}$.

Bullinger's Critical Lexicon and Concordance to the Eıglish and Greek New Testameut. Royal 8vo. 15s.

Colenso on the Pentatench and Book of Joshua. Crown 8ro. 6s.

Conder's Handbook of the Bible. Post 8vo. 7s. $6 d$.

Conybeare \& Howson's Life and Letters of St. Paul:-

Library Edition, with Maps, Plates, and Woodcuts. 2 vols. square crown 8 ro. 21 s.

Student's Edition, revised and condensed, with $\$ S$ Illustrations and Maps. 1 vol. crown 8 ro. $6 s$.

Cox's (Homersham) The First Century of Christianity. 8vo. 12s.

Davidson's Introduction to the Study of the New Testament. 2 vols. $8 \mathrm{vo}$. 30s.

Edersheim's Life and Times of Jesus the Diessiah. 2 vols. $8 \mathrm{vo} .21$ s.

- Prophecy and History in relation to the liessiah. 8vo. 12s.

Ellloott's (Bishop) Commentary on St. Paul's Ejistles. 8vo, Corinthians I. 16s. Cralatians, 8s. 6d. Ephesians, 8s. 6d. Pastoral Epistles, 10s, 6d. Puilippians, Colossians and Philemon, 10s. Gd. Thessalonians, 7s. 6d.

- Lectures on the Life of our Lord. 8ro. $12 \mathrm{~s}$.

Brwald's Antiquities of Israel, translated by Solly. $8 \mathrm{vo} .12 s, 6 d$.

- History of Israel, translated by Carpenter \& Smith. 8 rols. 8ro. Vols. 1 \& 2, 24s. Vols. 3 \& 4, 21s. Vol. 5, 18s. Vol. 6, 16s. Vol, $7,21 \mathrm{~s}$. Vol. 8,18 s.

Hotart's Medical Language of St. Lnke. $8 \mathrm{ro}, 16 s_{*}$

Hopkins's Christ the Consoler. Fep. 8 vo. 2s. 6\%.

LONGMLANS, GREEN, \& CO., London and New York. 


\section{General Lists of Works.}

Jameson's Sacred and Iegendary Art, 6 rols. square 8vo.

Legends of the Madonna. 1 rol. 21s.

- - - Monastic Orders 1 vol. 21s.

- - - Saints and Martyrs. 2 vols. 31s, 6d.

- - - Saviour. Completed by Lady Easclake. 2 vol3. 423.

Jukes's New Man and the Eternal Life. Crown 8vo. 6 s.

- Second Death and the Restitution of all Things. Crown 8vo. 3s, 62.

- Types of Genesis. Crown 8vo. 7s. 6d.

- The Mystcry of the Kingdom. Crown 8vo. 3s. $6 d$.

- The Names of God in Holy Scripture. Crown 8vo. 4s. $6 d$.

Lenormant's New Translation of the Book of Genesis. Translated into English. 8จ0. 108. 6\%.

Lyra Germanica : Hymns translated by Miss Winkworth. Fcp. 87o. 58.

Macdonald's (G.) Unspoken Sermons. Two Series, Crown 8vo. 3s. 6d, each.

- The Hiracles of our Lord. Crown 8vo. 3s, $6 d$.

Manning's Temporal Mission of the Holy Ghost. Crown 8vo. 8s. $6 d$.

Martineau's Endeavours after the Christian Life. Crown 8vo. 7s, 6d.

- Hymns of Praise aud Prayer. Crown 8vo. 4s. 6d. 32mo. 1s. 6d.

- Sermons, Hours of Thought on Sacred Things, 2 vols, 7s, 6d. each.

Max Mriuller's Origin and Growth of Religion. Crown 8vo. 7s. $6 d$.

- - Science of Religion. Crown 87o. $7 s .6 d$.

Monsell's Spiritual Songs for Sundays and Holidays. Fcp. 8ro. 58. 18mo. 2s.

L̛owman's Apologia pro Vitâ Suâ. Crown 8vo. 6s.

- The Arians of the Fourth Ceutury. Crown 8vo. 6s.

- The Idea of a University Defined and Illustrated. Crown 8vo.7s.

- Historical Sketches. 3 vols. crown 8vo, 6s, each.

- Discussions and Arguments on Various Subjects. Crown 8ro. 6s.

- $\Delta$ Essay on the Development of Christian Doctrine. Crown 87o. 6s.

- Certain Difficulties Felt by Anglicang in Catholic Teaching Considered. Vol. 1, crown 8vo. 7s. 6d. Vol. 2, crown 8vo. 5s.6d.

- The Via Media of the Anglican Church, Ilinstrated in Lectures, \&c. 2 vols. crown $8 \mathrm{vo}$. 6s. esch.

- Essajs, Critical and Historical. 2 vols. crown 8vo. $12 s$.

- Essays on Biblical and on Ecclesirstical Mirucles, Crown 8ro. 68.

- Sn Essay in Aid of a Grammar of issent. 7s. $6 d$.

- Belect Treatises of St. Athanasius in Controversy with the Ariaus. Translated. 2 vols, crown 8vo, 158.

Overton's Life in the Euglish Church (1660-1714). 8vo. 14s.

Roberts' Greek the Language of Christ and Fiis Aposties. 87o. 18s.

Supernatural Religion. Complete Edition. 3 vols. 8 vo. $36 s$.

Younghusband's The Story of Our Lord told in Simple Language for Children.

Illustrated. Crown 87o. 2s. $6 \mathrm{~d}$. cloth plain ; $38.6 \mathrm{~d}$. cloth extra, gilt edges.

\section{TRAVELS, ADVENTURES, \&CC.}

Boker's Eight Years in Ceylon. Crown 8vo. 5 s.

- Rifle and Hound in Ceylon. Crown 8vo. 5 s.

Brassey's Sunshine and Storm in the East. Library Edition, 8vo. 21s. Cabinet Fidition, crown 8vo. 7s. 6d. Popular Edition, 4to. 6d.

LONGMANS, GREEN, \& CO., London and New York. 
Brassey's Voyage in the 'Sunbeam.' Library Edition, 8v0.21s. Cabinot Edition, crown 8vo. 8s. 6d. School Edition, fcp.870.2s. Popular Edition, 4 to. $6 d$.

- In the Trades, the Tropics, and the 'Roaring Forties.' Cabinet Edition, crown Svo. 17s. 6d. Popular Edition, 4to. $6 d$.

Crawford's Reminiscences of Foreign Travel. Crown 8vo. 5 s.

Froude's Oceans ; or, England and her Colonics. Cr. 8vo.2s. boards ; 2s. $6 d$. cloth. - Tho English in tho West Indies. 8vo. $18 \mathrm{~s}$.

Howitt's Visits to Remarkable Places, Crown 8vo. 5 s.

James's The Long White Mountain ; or, a Journey in Manchuria. 8vo. 24s.

Lindt's Picturesque New Guinea, 4to. $42 s$.

Pennell's Our Sentimental Journey through France and Italy. Illustrated. Crown 8vo.6s.

Riley's Athos; or, The Mountain of the Mlonks. 8vo. $21 \mathrm{~s}$.

Three in Norway. By Two of Them. Illustrated. Crown 8vo. 2s. boards; 2s. $6 d$. cloth.

\section{WORKS OF FICTION.}

Anstey's The Black Poodle, \&c. Crown 8ro. 2s. boards; 2s. 6d. cloth.

Besconsfield's (The Earl of) Novels and Tales, Hughenden Edition, with 2 Portraits on Steel and 11 Vignettes on Wood. 11 vols. crown 8vo. £2.2s. Cheap Edition, 11 vols, crown $8 \nabla 0.1$ s. esch, boards ; 1 s. 6 d. cach, cloth.

\begin{tabular}{l|l} 
Lothair. & Contarini Fleming. \\
Sybil. & Alroy, Ixion, \&c. \\
Coningsby. & The Young Dake, \&o. \\
Tancred. & Vivian Grej. \\
Venetia. & Endymion. \\
Henrietta Temple. &
\end{tabular}

Gilkes' Boys and Níasters. Crown 8vo. sิs. $6 d$.

Haggard's (H. Rider) She: a History of Adventure. Crown 8vo. 6s.

- - Allan Quatermain. Illustrated. Crown 8vo. 6s.".

Harte (Bret) On the Frontier. Three Stories. 16mo. 1s.

- - By Shore and Sedge. Three Stories. 16mo. 1s.

- - In the Carquinez Wooủs. Crown 8vo. 1s. boards ; 1s. 6d. cloth.

Lyall's (Edna) The Autobiography of a Slander. Fcp. 1s. sewed.

Mieiville's (Whyte) Nortls. 8 vols. fcp. 8 vo. 1s. each, boards; $13.6 d$. each, cloth.

Digby Grand.

General Bounce.

Kato Coventry.

Tho Gladiators.

Good for Nothing.

Holmby House.

The Interpteter.

The Queen's Maries.

Molcsworth's (Mrs.) Marryiog and Giving in Marriage. Crown 8vo. 2s.6d. Novels by the Author of 'The Atelier du Lys':

The Atelier du Lys; or, An Art Student in the Reign of Terror. Crown $8 \nabla 0,2 s .6 d$.

Aiademoisello Mrorl: a Tale of Modern Rome. Crown 8vo. 2s. 6d.

In the Olden Time: a Tale of the Peasant War in Germany. Crown 8vo.2s. 6d.

Hester's Venture. Crowu 8จ0. 2s. 6d.

Oijphant's (Mrs.) Madam. Crown 8vo. 1s. boards ; 1s. 6d. cloth.

- - II Trust: the Story of a Lady and her Lover. Crown 8vo. 1s. boards; 1 s. 6 d. cloth.

Payn's (James) The Luck of the Darrells. Crown 8vo. 1s. boards; 1s. 6d. cloth.

- - Thicker than Water. Crown 8v0. 1s. boards; 1 s. $6 d$. cloth.

Rcalcr's Fairy Prince Follow-my-Lead. Crown 8vo. 2s. 6u.

- The Ghost of Irankinshaw ; and other Tales. Fcp. 8vo. 2s, 6a.

LONGIANS, GREEN, \& CO., London and New York. 
3ewell's (Mriss) Stories and Traes. Crown 8ro. 1s. each, boards ; 1s.6d. cloch ;

2s. 6 d. cloth extrs, gili edges.

Amy Herbert. Cleve Hall.

The Earl's Danghter.

Experience of Life.

Gertrude. Ivers.

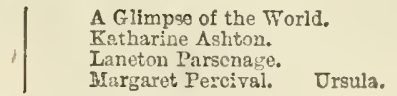

Stovenson's (R. L.) The Dynamiter. Fcp. 8vo. 1s. sewed; 1s. 6d. cloth.

- - Strange Case of Dr. Jekyll and Mr. Hyde. Fep. 870. 1\% sewed; 1s. 6d. cloth.

Trollope's (Anthong) Novels. Fcp. Svo. 1s, exch, boards; 1s. 6l. cloth.

The Warden

Barcbester Towers.

\section{FOETRY AND THE DRAMA.}

Armstrong's (Ed. J.) Poetical Works. Fcp. 8vo. 5s.

- (G. F.) Poetical Works:-

Poems, Ljrical and Dramatic. Fcp. 8 vo. 63 .

Ugone: a Trageìy. Fop. 8vo. 6s.

A Garland from Greece. licp. 8 vo.9s.

King Sanl. Fep. Svo. 5s.

King David. Fcp. 8vo. $6 s$.

King Solomon. Fep. 8vo. 6s.

Ballads of Berks. Edited by Andrew Lang. Fcp. 8vo. 6s.

Bowen's Harrow Songs and other Verses. Fep. 8vo. 2s. 6d.; or printed on band-made paper, 5 s.

Bowdler's Family Shakespeare. Medium 870. 14s. 6 vols. fep. 8 vo. 21 s.

Dante's Divine Comedy, translated by Janes Innes Minchin. Crown 8vo. 15\%.

Goetine's Faust, translated by Birds. Large crown 8vo. 12s. $6 d$.

- - translated by Weub. Svo. 12s, 6d.

- - edited bj Selss. Crown 8vo. 5 s.

Ingelow's Poems. 2 Vols. fcp. 8vo. 12s.; Vol. 3, fcp. 8vo. 5 s.

- Ljrical and other Poems. Fcp. 8ro. 2s. 6d. cloth, plaiv; 3s. cloth, gilt edges.

Eendall's (Mrs:) Dreams to Sell. Fep. 8vo. 6s.

Mracaulay's Iajs of Ancient Rome. 1llustrated by Scharf. 4to. 10s. 6d. Popular Edition, f(p. 4to, 6d. swd., 1s, cloth.

- Lays of Ancient Rome, with Irry and the Armada. Illestzated by

Weguelin. Crown 8 vo. 3s. 6d. gilt eùges.

Nesbit's Lays and Legends, Crown 8 vo. 5 s.

Newman's The Dream of Gerontins. $16 \mathrm{mo}, 6 d$. sewed; 1 s. cloth.

- Verses on Various Occasions. Fep. 8ro. 6s.

Reeder's Toices from Flowcrland, a Birthday Look, 2s, 6d. ciott, 3s, 6d. roan.

Southey's Poetical Works. Medium Svo, 14s.

Steverison's A Child's Garden of Verses. Fcp. 8vo. 5s.

Virgil's IFneid, translated by Conington. Crown 8vo. 2s.

- Poems, translated into English Proso. Crown 8ro. 9s.

AGRICULTURE, HORSES, DOGS, AFID CATTLE.

Titanygram's Horses and Stables. 8vo. 5s.

Iloyd's The Science of A griculture. 8vo.12s.

Loudon's Encyclopxdis of Agriculture. $21 s$.

Prothero's Pionears and Progress of English Farming. Crown 87o, 5s.

Stecl's Disezses of the Ox, a Jranual of Bovine Yathology. 8vo. 1 šs.

- - - Dog. Svo. 10s.6d.

LONGMANS, GREEN, \& CO., London and New Tork. 
Stonebenge's Dog in Health and Disease. Square crown 8ro. 7s, 6d. - Greyhound. Square crown 8ro. 15s.

Taylor'a Agricultaral Noto Book. Fcp. 8vo. 2s.6d.

Ville on Artificial Manures, by Crookes, 8vo, 21s.

Youatt's Work on the Dog. 8vo. 6s.

- - - - Horse. 8vo.7s.6d.

\section{SPORTS AND PASTIMES.}

The Badminton Library of Sports and Pastimes. Edited by the Duke of Beanfort and A. E. T. Watson. With numerous Illustrations. Cr. 8vo. 10s.6d. each. Hunting, by the Duke of Beaufort, \&c.

Fishing, by H. Cholmondeley-Pennell, \&c. 2 vols.

Racing, by the Earl of Suffolk, \&c.

Shooting, by Lord Walsingham, \&c. 2 vols,

Cycling. By Viscount Bury.

Athletics and Football. By Montague Shearman, \&c.

Boating. By W. B. Woodgate, \&c.

Cricket. By A. G. Steel, \&c.

Driving. By the Duke of Beaufort, \&c.

* * Other Tolumes in preparution.

Campbell-Walker's Correct Card, or How to Play at Whist. Ficp. 8ro. 2s. 6d. Ford's Theory and Practice of Archery, revised by W. Butt. 8vo. 14s. Francis's Treatise on Fishing in all its Branches. Pcat 8vo, 15s.

Longman's Chess Openings. Fcp. 8ro, 2s, $6 d$.

Pease's The Cleveland Hounds as a Trencher-Fed Pack. Royal 8vo. 18. Pole's Theory of the SIodern Scientific Gamo of Whist. Fcp.87o. 2s. 6d. Proctor'8 How to Play Whist. Crown 8vo. 5s.

Ronalds's Fly-Fisher's Entomology. 8vo. 14s.

Wilcocks's Sea-Fiaherman. Post 8vo. 6s.

\section{ENCYCLOPFDIAS, DICTIONARIES, AND BOOKS OF REFERENCE.}

Acton's Modern Cookery for Private Families. Fcp 87o. 4s. 6 d.

Ayre's Treasury of Bible Knowledge. Fcp. 8vo. 6s.

Cabinet Lawyer (The), a Popular Digest of the Laws of England. Fcp. 8vo. 9s.

Cates's Dictionary of General Biography. Medium 8vo. 28s.

G.wilt's Encyclopadfa of Architecture. 8vo. 52s. 6d.

Keith Johnston's Dictionary of Geography, or General Gazetteer. 8vo.42s.

M'Culloch's Dictionary of Commerce and Commercial Navigation. 8vo.63s.

Maunder's Biographical Treasury. Fcp. 8vo. 6s.

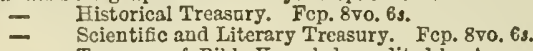

- Treasury of Bible Enowledge, edited by A yre. Fcp. 8vo. 6s.

- Treasury of Botany, edited by Lindley \& ifoore. Two Parts, 12 s.

- Treasury of Geography. Fcp. 8vo. tis.

- Trcasury of Knowlcdge and Library of Reference. Fcp. 8vo.63.

- Treasury of Natural History. Fep. 8vo. 6s.

Quain's Dictionary of Medicine. Medium $8 \mathrm{ro}, 31 s .6 d$., or in 2 vols. 34s.

Reeve's Cookery and Housekeeping. Crown 8vo. 5s.

Rich's Dictionary of Roman and Greek Antiquities. Crown 8vo, 7s.6d,

Roget's Thesaurus of English Words and Phrases. Crowa 870.10\%.6d.

Wwich's Popular Tables, by Marriott. Crown 8vo. 10s, $6 d$.

\section{WORKS BY MRS. DE SALIS.}

Savouries à la Mode. Fcp. 8vo. 1s. I Sweets and Supper Dishes, à la Modo. Entrées à la ilude. Fep. Sro. is. $6 a$.

Soups and Dressed Fish à la Mrode. Fep. 8ro. 1s. $6 d$.

Fop. 8v0. 1s.6d.

Oysters à la Mode. Fcp. 8vo. 1s. $6 d$.

Vegetables à la Mode. Fcp.8ro.1s.6d.

LONGMANS, GREEN, \& CO., London and New York. 


\section{A SELECTION \\ or EDUCATIONAL WORES.}

TEXT-BOOKS OF SCIENCE.

FULLY ILUUSTRATED.

Abney's Treatise on Photography. Fcp. 870. 3s, 66,

Anderson's Strength of Materials. 3s. $6 d$.

Armstrong's Organic Chemistry. $3 s_{*} 6 d$.

Ball's Elements of Astronomy. 6s.

Barry'a Railway Appliances. 3s. 6d.

Bauerman's Systematic Mineralogy. 6s.

- Descriptive Mineralogy. 6s.

Bloxam and Huntington's Metals, 5s.

Glazebrook's Physical Optics. 6s.

Glazebrook and Shaw's Practical Physics. 6s.

Gore's Art of Electro-Mretallurgy. 6s.

Griffin's Algebra and Trigonometry. 3s. 6d. Notes and Solutions, 3: .6d.

Holmes's The Steam Engine. $6 s$.

Jenkin's Electricity and Magnetism. 3s. $6 u$.

Misuwell's Theory of Heat. 3s. $6 \boldsymbol{a}$.

Merrifeld's Technical Arithmetic and Mensuration, 3s, 6d. Keg, 3s,6d. Miller's Inorganic Chemistry. 3s. $6 d$.

Preece and Sivewright's Telegraphy. 5s.

Rutley's Study of Rocks, a Text-Book of Petrology. 4s. 6d.

Shelley's Workshop Appliances. 4s. $6 d$.

Thomés Structural and Physiological Botany. 6s.

Thorpe's Quantitative Chemical Analysis. 4s. 6d.

Thorpe and Muir's Qualitative Analysis. 3s, 6d.

Tilden's Chemical Philosophy. 3s, 6d. With Anewers to Problams, 4s, 6d.

Unwin's Elements of Machine Design. 6s.

Watson's Plane and Solid Geometry. 3s.6d.

\section{THE GREEK LANGUAGE.}

Bloomfield's College and School Greek Testament. Fcp. 87o, 5s.

Bolland \& Lang's Politics of Aristotle. Post 8vo. 7s.6 $d$.

Collis's Chief Tenses of the Greek Irregular Verbs. $8 \mathrm{ro} .1 \mathrm{~s}$.

- Pontes Græci, Stepping-Stone to Greek Grammar. 12mo. 3s.6d.

- Praxis Græca, Etymology. 12mo. 2s.6d.

- Greek Verse-Book, Praxis Iambica. $12 \mathrm{mo} .4 s .6 d$.

Farrar's Briel Greek Syntax and Accidenco. 12mo. 4s, $6 d$.

- Greek Grammar Rules for Harrow School. 12mo, 1s. 6d.

Geare's Notes on Thucydides. Book I. Ficp. 8ro, 2s, 6d.

LONGMANS, GREEN, \& CO., London and New York. 
Hew1tt's Greek Ezamination-Papers. $12 \mathrm{mo}$. Is. $6 d$.

Isbister's Xenophou's Anabasis, Eooks I. to III. mith Notss. 12me, 38.6 . Kennedy's Greek Grammar. 12mo. 4s.6d.

Iiddell \& Scott's Englisl1-Greek Lexicen, 4 to. 36s, ; Square 12mo. 7s. 6d.

Mahaffy's Classical Greek Literature. Crown 8vo. Poets, 7s, 6d. Prose Writers, 7s. $6 \mathrm{~d}$.

MPorris's Greek Lessons. Square 18mo. Part I. 2s. 6d.; Part II. 1s.

Parry's Elementary Greek Grammar. 12mo. 3s. $6 d$.

Plato's Republic, Dook I. Greek Text, English Notes by Hardy. Crown 8ro. 33. sheppard and Evans's Notes on Thueydides. Cromn 8vo. 7s. $6 d$.

Thucydides, Eook IV. with Notes by Barton and Chavasse. Crown 8vo. 5s. Valpy's Greek Delectus, improved by White. 12mo. 2s.6d. Key, 2s.6d. White's Xenophon's Expedition of Cyrus, with English Totes. 12mo. 7s. 6a. Wilkins's Mannal of Greek Prose Composition. Crown 8ro. 5s. Key, 5s.

- Exercises in Greek Prose Composition. Crown 8ro.4s. 6d. Бeу, 2s.6d.

- New Greek Delectus. Crown 8vo. 3s.6d. Fes, 2s.6d.

- Progressive Greek Delectus. 12mo. 4s. Key, 2s.6d.

- Progressive Greek Anthology. 12mo. 5s.

- Scriptores Attici, Excerpts with English Notes. Crown 8vo. 7s. 63.

- Speeches from Thucydides translated. Post 8vo.6s.

Yonge's English-Greek Lexicon. 1to. 21s.; Square 12mo. 8s. 6d.

\section{THE LATIN LANGUAGE.}

Bradley's Latin Prose Exercises. 12mo. 3s. 6d. Key, 5 s.

- Continuous Lessons in Latin Prose, $12 \mathrm{mn}$. $5 \mathrm{~s}$. Key, $5 s_{0} 6 \boldsymbol{d}$,

- Cornelins Nepos, improred by White. $12 \mathrm{mo} .3$ s. $6 d$.

- Eutropius, improted by White. 12mo. $2 s .6 d$.

- Ovid's Metamorphoses, improved by White. 12mo. 4s.6d.

- Select Fables of Phadrus, improved by White. 12no. 2s.6d.

Collis's Chief Tenses of Latin Irre sular Verbs. 8ro. 1..

- Pontes Latini, Stepping-Stone to Latin Grammar. 12mo. 3s.6a.

Hevitt's Latin Examination-Papers. 12mo. 1s. $6 d$.

Isbister's Cæsar, Books I.-VII. $12 \mathrm{mo} .4 \mathrm{~s}$; ; or with Teading Lessons, 4s. 6 d.

- Cæsar's Commentaries, Buoks I.-V. 12mo. 3s. 6d.

- First Baok of Cæsar's Gallic War. 12mo, 1s. $6 d$.

Jerram's Latiné Reddenda. Crown 8vo. 1s. $6 d$.

Kennedy's Child's Latin Primer, or First Latin Lessons, 12mo. 2s.

- Child's Latin Accidence. 12mo. 1s.

- Elementary Latin Grammar. 12mo. $3 s_{0} 6 \mathrm{~d}$.

- Elementary Latin Feading Book, or Tirocinium Latinum. 12mo. 2s.

- Latin Prose, Palastra Stili Latini, 12mo.6s.

- Latin Vocnbulary. 12mo. 2s.6d.

- Subsidia Primaria, Exercise Eooks to the Public School Latin Primer.

I. Accidence and Simple Construction, 2s. 6d. II. Syntax, 3s.6d.

- Key to the Exercises in Subsidia Primaria, Parts I. and 'II. price 5.

- Subsidia Primaria, III. the Latin Compound Sentence. 12mo. 1s.

IONGMANS, GREEN, \& CO., London and NeTr York. 


\section{A Selection of Educational Works.}

Kennedy's Curriculum Stili Latini. 12rno. 4s. 6d. Key, 7s. €d.

- Pelæstra Latina, or Second Latiu Rending Book, $12 \mathrm{mo} .58$.

Moody's Eton Latin Grammar. 12mo. 2s, 6d. The Accilence separatcly, 1s.

Morris's Elementa Latina. Fcp. 8vo. 1s.6d. Key, 2s, $6 d$.

Parry's Origines Romanæ, from Livy, with English Fotes, Crown 870.4 s.

The Public Scbool Latin Primer. 12mo. 2s. $6 d$.

- - - - Grammar, by Rev. Dr. Kennely. Post 8vo. 7s. 6r.

Prendergast's Mastery Series, Manual of Latin. $12 \mathrm{mo}, 2 s, 6 d$.

Rapier's Introduction to Composition of Latin Verse. 12mo. 3s.6d. Key, 2s.6d.

Bheppard and Turner's Aids to Classical Study. 12mo. 5s. Eej, 6s.

Valpy's Latin Delectus, improved by White. 12mo. 2s, 6d. Key, 3s. 6d.

Virgil's 2Eneid, translated into English Terse by Conington. Crown 8vo. 9s.

- Works, edited by Kennedy. Crown 8vo. 10s. Gd.

- $\quad$ - translated into English Prose by Conington. Crown 8vo. 9s.

Walford's Progressive Exercises in Latin Elegiac Verse. 12mo. 2s. 6d. Key, 53. White and Riddle's Large Latin-English Dictionary. 1 vol. 4to. 21s.

White's Concise Latin-Eng. Dictionary for University Students. Royal 8vo. 12s.

- Junior Students' Eng.-Lat. \& Lat.-Eng. Dictionary. Square 12mo. 5s.

Separately (The Latin-English Diclionary, price 3s.

Yonge's Latin Gradus. Post 8 vo. $9 s$; ; or with Appendix, 12s.

\section{WHITE'S GRAMMAR-SCHOOL GREEK TEXTS.}

ZEsop (Fables) \& Palæphatus (Miyths). $32 \mathrm{mo}$. $1 s$.

Enripides, Hecuba. $2 s$.

Homer, Iliad, Book I. 1s.

- Odyssey, Book I. Is.

Lucian, Select Dialogues. 1s.

Xenopbon, Anabasis, Books I. III. IV.

V. \& V l. 1s. $6 d$. each ; Book 11. 1s. ; Book VII. $2 s$.

Tho Four Gospels in Greek, with Greek-English Lexicou. Edited by Jchn T. White, D.D. Uxon. Square 32 mo. price 5 s.
X'nophon, Book I. without Vocabulary. $3 d$.

St. Niatthew's and St. Luke's Gospels. 2s. fid, cach.

St. Mrark's and St. John's Gospels. 1s. 6 d. each.

The Acts of the Apostles. $2 s, 6 d$.
st. Paul's Eyistle to the Lomaus. Is. $6 d$.

\section{WHITE'S GRAMMAR-SCHOOL LATIN TEXTTS.}

Casar. Gallic War, Books I. \& 1r. V. \& V1. Is. each. Book I. without Vocabulary, $3 d$.

Cesar, Gallic War, Eooks III. \& IV. 9 d. each.

Cesar, Gallic War, Book VII. Is. $6 a^{\text {. }}$. Cicero, Cato Major (Old Age). 1s. Gd. Cicero, Lælius (Frienrship). 1s. 6 d. Eutropius, Roman Histor, Bcoks I. \& II. 1s. Books III. \& IV. 1s.

Hirace, Odes, Books I. II. \& IV. 1s, each. Horace, Odes, Book 11I. 1s. $6 d$.

Horace, Epodes aud Carmen Seculare. Is.

Nepos, Miltianes, Simon, Paasanias, Aristides. $9 d$.

Ovid. Selcetious from Epistles and Fasti. 1s.

Ovid, Select Myths from Metamorpboses. $9 d$.

Thiedrus, Select Fasy Fables,

Phredrus, Fables, Books I. \& II. 18.

Sailust, Bellum Catilinaritzm. 1s. $6 d$.

Virgil, Georgies, Book IV. is.

Virgil, Eneid, Boolss I. to VI. 1s, each. Book I. without Vocabulary, $3 d$.

Virgil, B̈neid, Bools VII. to XII. 18. 6d. each.

LONGNATS, GREEN, \& CO., Iondon and New Forl. 


\section{THE FRENCH LANGUAGE.}

Albités's How to Speak French. Fcp. 8vo. 5s. 6d.

- Instantaneous French Exercises. Fcp. 2s. Key, 2s.

Cassnl's French Genders. Crown 870. 3s. $6 d$.

Cassal \& Karcher's Graduated French Translation Book.

Part I. 3s. 6.i.

Part II. 5s. Key to Part I. by Professor Cassal, price 5s.

Contanseau's Practical French and English Dictionary. Post 8vo. 3s. 6 d.

- Pocket French and English Dictionary. Square 18mo, 18,6d.

- Fremières Lectures. 12mo. 2s. 6d.

- First Step in French. 12mo. 2s. 6d. Key, 3s.

- French Accidence, 12mo. 2s.6a.

- - Grammar. 12mo. 4s. Key, 3s.

Contanseau's Middle-Class French Course. Fcp. 8vo.:-

Accidence, $8 \pi$.

Siyntax, $8 \dot{d}$.

French Conversation-Book, $8 d$.

First French Exercise-Book, $8 d$.

Secund French Exercise-Book, $8 d$.

French Translation-Book, $8 \boldsymbol{d}$.

Ersy French Delectns, $8 d$.

First French Reader, $8 d$.

Second French 1ieader, $8 d$.

French and English Dialogueg, $8 d$.

Contanscan's Guide to French Translation. 12mo. 3s.6d. Key 3s.6d.

- Prosateurs et Poètes Français. 12mo. $5 s$.

- Précis de la Littérature Française, 12mo. 3s, 6d.

- Abrégé de l'Histoire de France. $12 \mathrm{mo}$. 2s. 6 d.

Féral's Chouns et Bleus, with Notes by C. Sankey, M.A. Fcp. 870. 2s. 6d. Jerram's Sentonces for Translation into French. Cr. 8vo. 1s. Key, 2s. 6d, Prendergast's Mastery Series, French. 12mo. 2s. $6 d$.

Souvestre's Philosophe sous les Toits, by Stièvenard. Square 18mo. 1s. 6d. Stepping-Stone to French Pronunciation. $18 \mathrm{mo} .1 \mathrm{~s}$.

Stievenard's Lectures Françaises from Modern Anthors. 12mo. 4s, 6d.

Rules and Exercises on the French Language. 12 mo. 3s. $6 d$. Tarver's Eton French Grammar. 12mo. 6s.6d.

\section{THE GERMAN LANGUAGE.}

Biackley's Practical German and English Dictionary. Post 8vo. 3s. 6d. Buchheim's German Poetry, for Repetition. $18 \mathrm{mo}$. 1s. 6 d.

Collis's Card of German Irregular Verbs. 8vo. $2 s$.

Fischer-Fischart's Flementary German Grammar. Fcp. 8ro. 2s, 6d.

Just's German Grammar. 12mo. 1s, $6 a$.

- German Reading Book. 12mo. 3s. 6d.

Longman's Pocket German and Tnglish Dictionary. Equare 18mo. 2s. 6 Naitel's Elementary German Course for Public Schools. Fcp. 8vo.

German Accidence. $9 a$.

German Syntax. $9 u$.

First German Exercise-Book. $9 d$.

Sccond German Excrcise-Book. $9 \dot{d}$.

German Prose Composition Book. 8d. First German Rearier. 9ä. Second German Reader. $\vartheta d$.

Prendergast's Mastery Scries, German, 12mo, 2s, 6 d.

Quick's Essentials of German. Crown 8vo. 3s. 6d.

Selsg's School Edition of Goethe's Faust. Crown 8vo. 5s.

- Outline of German Literature. Crown 8vo. 1s.6d.

Wirth's German Chit-Chat. Crown 8 ro. 2s. 6 .

LONGMANS, GREEN, \& CO., London and Now York.

Spottisuroode \& Co. Printers, Nero-strect Square, London.

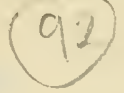






\section{PLEASE DO NOT REMOVE CARDS OR SLIPS FROM THIS POCKET}

\section{UNIVERSITY OF TORONTO LIBRARY}

\section{Bionicd}


